Florida International University FIU Digital Commons

6-26-2017

\title{
Synthesis of Gemcitabine Analogues with Silicon- Fluoride Acceptors for 18F Labeling
}

Cesar Gonzalez-Espinoza

cgonz042@fiu.edu

DOI: $10.25148 /$ etd.FIDC001927

Follow this and additional works at: https://digitalcommons.fiu.edu/etd

\section{Recommended Citation}

Gonzalez-Espinoza, Cesar, "Synthesis of Gemcitabine Analogues with Silicon-Fluoride Acceptors for 18F Labeling" (2017). FIU Electronic Theses and Dissertations. 3469.

https://digitalcommons.fiu.edu/etd/3469 


\section{FLORIDA INTERNATIONAL UNIVERSITY}

Miami, Florida

\section{SYNTHESIS OF GEMCITABINE ANALOGUES WITH SILICON-FLUORIDE ACCEPTORS FOR ${ }^{18} \mathrm{~F}$ LABELING}

A dissertation submitted in partial fulfillment of the requirements for the degree of DOCTOR OF PHILOSOPHY

in

CHEMISTRY

by

Cesar Gonzalez 
To: Dean Michael R. Heithaus

College of Arts, Sciences and Education

This dissertation, written by Cesar Gonzalez, and entitled Synthesis of Gemcitabine Analogues with Silicon-Fluoride Acceptors for ${ }^{18} \mathrm{~F}$ Labeling, having been approved in respect to style and intellectual content, is referred to you for judgment.

We have read this dissertation and recommend that it be approved.

David Chatfield

Watson Lees

Kevin O'Shea

John Makemson

Stanislaw F. Wnuk, Major Professor

Date of Defense: June 26, 2017

The dissertation of Cesar Gonzalez is approved.

Dean Michael R. Heithaus College of Arts, Sciences and Education

Andrés G. Gil

Vice President for Research and Economic Development and Dean of the University Graduate School

Florida International University, 2017 
(C) Copyright 2017 by Cesar Gonzalez

All rights reserved. 


\section{DEDICATION}

I would like to dedicate this dissertation to everyone that helped through this period of my life, specially my family which always encouraged me during the good and the not so good times. Always keep it tight, keep it alright. 


\section{ACKNOWLEDGMENTS}

I would like to thank my committee members, Watson Lees, Kevin O'Shea, David Chatfield and John Makemson for their support and advice throughout my graduate studies. I also like to extend my gratitude towards everyone at the Department of Chemistry and Biochemistry at Florida International University.

I would also like to thank all my collaborators whom their great help have made this dissertation what it is. I would like to thank Dr. Cheppail Ramachandran from the Department of Pathology at Nicklaus Children's Hospital for studying the cytostatic activities of my 4- $N$-modified gemcitabine analogues in his L1210 cell line. Also, thank you to Dr. Alejandro Barbieri at FIU's department of Biological Sciences for providing cell and fluorescence studies with his HEK 293 cell line in order to have a better understanding of cellular uptake on my 4- $N$-modified gemcitabine analogues. A very special and appreciated thank you to Dr. Michael van Dam and his coworkers from the Crump Institute for Molecular Imaging in the University of California Los Angeles for their work in ${ }^{18} \mathrm{~F}$ labeling and PET imaging of my 4- $\mathrm{N}$-modified gemcitabine analogues in WT C57BL/6 mice.

Finally, I would like to thank my advisor, Dr. Stanislaw F. Wnuk, for all his guidance and always keeping my in the right track. I would like to thank all of my lab mates, previous and current, for their advice and friendship. 


\title{
ABSTRACT OF THE DISSERTATION
}

\section{SYNTHESIS OF GEMCITABINE ANALOGUES WITH SILICON-FLUORIDE ACCEPTORS FOR ${ }^{18} \mathrm{~F}$ LABELING}

\author{
by \\ Cesar Gonzalez
}

Florida International University, 2017

Miami, Florida

\section{Professor Stanislaw F. Wnuk, Major Professor}

Gemcitabine $(\mathrm{dFdC})$ is an effective chemotherapeutic nucleoside analogue for treatment of cancers and solid tumors. Gemcitabine's chemotherapeutic effect is limited by its rapid intracellular deamination by cytidine deaminase into the inactive uracil derivative. Herein, I designed and synthesized two sets of gemcitabine analogues: i) a 4$N$-alkyl gemcitabine analogue containing a $\beta$-keto sulfonate moiety, and ii) clickable analogues possessing silicon-fluoride acceptor building blocks. Both of these sets of analogues undergo efficient fluorination, including fluorination protocols compatible with ${ }^{18} \mathrm{~F}$ labeling.

The synthesis of the 4- $N$-alkyl gemcitabine analogue bearing $\beta$-keto sulfonate moiety began with reaction of 4- $\mathrm{N}$-tosylgemcitabine with 1-amino-10-undecene, followed by a series of oxidation and sulfonation steps which yielded the $\beta$-keto sulfonate analogues.

The coupling of gemcitabine with carboxylic acids using peptide coupling conditions afforded 4- $N$-alkanoyl analogues with a terminal alkyne or azido moiety. Click reaction of these 4- $N$-alkanoyl analogues with dialkylsilyl building blocks gave 4-Nalkanoylsilanegemcitabine analogue. Reaction of 4- $N$-tosylgemcitabine with 
functionalized azidoalkyl amines provided 4- $\mathrm{N}$-alkylgemcitabine with a terminal azido group. Coupling of the latter with dialkylsilyl building block provided 4- $\mathrm{N}$ alkylsilanegemcitabine. Fluorination of $4-N$-alkyl gemcitabine analogues with $\beta$-keto sulfonate moieties and of the trisubstituted silane derivatives with KF and 18-Crown-6 $\left(\mathrm{CH}_{3} \mathrm{CN} / 75^{\circ} \mathrm{C} / 0.5-1 \mathrm{~h}\right)$, gave the corresponding fluorinated 4- $\mathrm{N}$-alkyl and alkanoyl gemcitabine analogues under conditions that are compatible with protocols for positron emission tomography (PET) ${ }^{18} \mathrm{~F}$ labeling. The $\left[{ }^{18} \mathrm{~F}\right]$ 4-N-alkyl and alkanoyl silane gemcitabine analogues were successfully synthesized on microscale and macroscale radiochemical protocols. The biodistribution of $\left[{ }^{18} \mathrm{~F}\right] 4-\mathrm{N}$-alkyl gemcitabine analogue was analyzed via PET imaging. The cytotoxicity activity of the silane gemcitabine analogues were studied in cancer L1210 and HEK 293 cell lines and their cellular uptake were investigated using HPLC analysis and fluorescence microscopy.

Reduction of ribono-1,4-lactones and gulono-1,4-lactone as well as ribono-1,5-lactone and glucono-1,5-lactones with LTBH (1.2 equiv.) in $\mathrm{CH}_{2} \mathrm{Cl}_{2}$ at $0{ }^{\circ} \mathrm{C}$ for 30 min provided the corresponding pentose or hexose hemiacetals in chemoselective fashion and in high yields. Commonly used in carbohydrate chemistry protecting groups such as trityl, benzyl, silyl, acetals and to some extent acyls are compatible with this reduction. 


\section{TABLE OF CONTENTS}

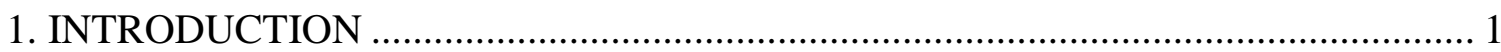

1.1. Gemcitabine: Chemistry and biological activity .................................................. 1

1.1.1. Gemcitabine: Anti-cancer mechanism of action and inhibition......................... 1

1.1.2. Gemcitabine: Design and synthesis of prodrugs ............................................ 3

1.1.3. Gemcitabine: Theranostic image-guided tumor agents ...................................... 5

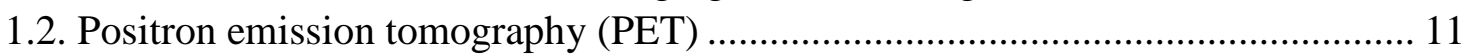

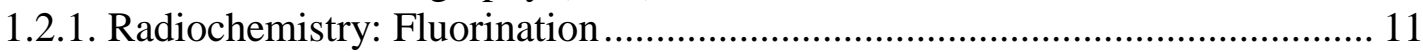

1.2.2. Positron emitting ${ }^{18} \mathrm{~F}$ radiotracers for anticancer therapy................................ 13

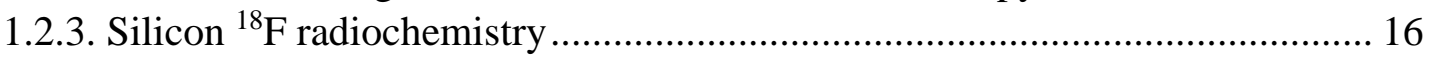

1.3. Reduction of lactones to hemiacetals .................................................................. 19

1.3.1. Synthetic significance of reduction of lactones to hemiacetals ....................... 19

1.3.2. Reducing agents for reduction of lactones to hemiacetals .............................. 22

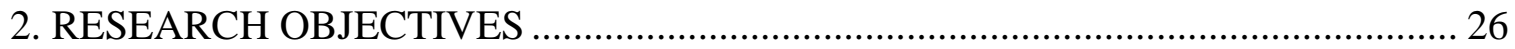

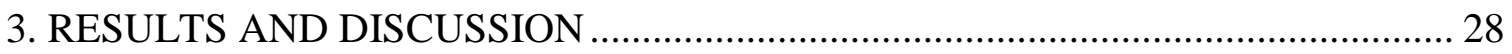

3.1. Design and synthesis of 4- $\mathrm{N}$-alkanoyl and $4-\mathrm{N}$-alkyl gemcitabine analogues ....... 28

3.1.1. 4- $N$-Alkyl $\beta$-keto sulfonate gemcitabine analogue......................................... 28

3.1.1.1. 4-N-Alkyl $\beta$-keto sulfonate gemcitabine analogue: Rationale ................. 28

3.1.1.2. 4-N-Alkyl $\beta$-keto sulfonate gemcitabine analogue: Synthesis ................. 29

3.1.1.3. 4-N-Alkyl $\beta$-keto sulfonate gemcitabine analogue: Fluorination studies. 34

3.1.2. 4- $N$-Alkyl and alkanoyl gemcitabine analogues with silicon-fluoride

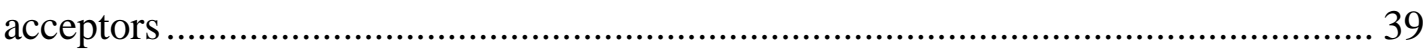

3.1.2.1. Silicon-fluoride acceptors gemcitabine analogues: Rationale .................. 39

3.1.2.2. Silicon-fluoride acceptors gemcitabine analogues: Synthesis .................. 40

3.1.2.3. Silicon-fluoride acceptors gemcitabine analogues: Fluorination studies.. 43

3.1.2.4. Silicon-fluoride acceptors gemcitabine analogues: Stability studies........ 46

3.1.2.5. Biological evaluation of the 4-N-alkyl \& alkanoyl gemcitabine

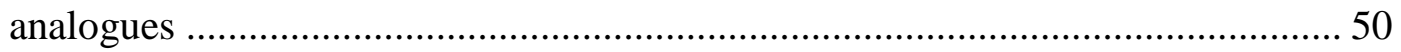

3.1.2.6. $\left[{ }^{18} \mathrm{~F}\right]$-Labeling of 4-N-alkanoyl and alkyl gemcitabine radioligands........ 57

3.1.2.7. Biological and PET evaluation of $\left[{ }^{18} \mathrm{~F}\right]-4-\mathrm{N}$-alkyl gemcitabine

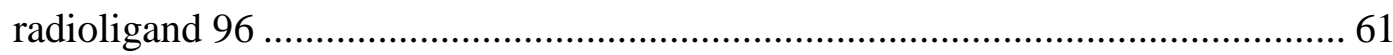

3.2. Reduction of sugar lactones to hemiacetals using lithium triethylborohydride ..... 65

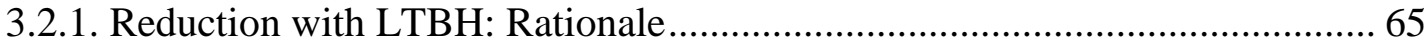

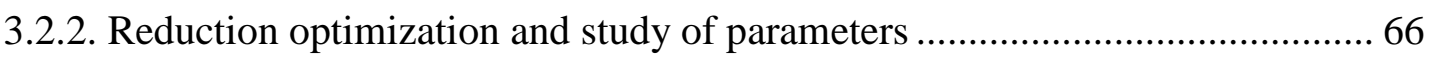

3.2.3. Reaction profile of reduction of lactone 97 to hemiacetal 98 ......................... 68

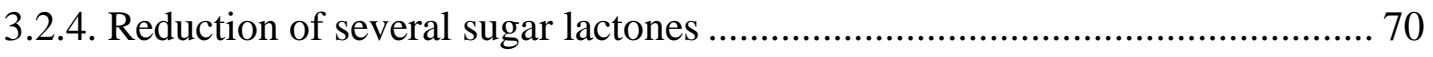

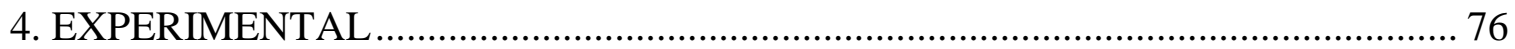


4.1. General Procedures ................................................................................... 76

4.2. Synthesis of 4- $N$-Alkyl $\beta$-keto sulfonate gemcitabine analogues ........................ 76

4.3. Synthesis of 4-N-alkanoyl and 4- $N$-alkyl clickable gemcitabine analogues with

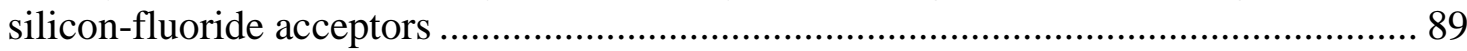

4.4. Reduction of sugar lactones to hemiacetals with LTBH ................................. 98

4.4.1. Typical procedure for reduction of the sugar lactones to hemiacetals with LTBH and selected products ${ }^{150}$........................................................................ 98

4.4.2. ${ }^{1} \mathrm{H}$ NMR reaction profile for reduction of sugar lactone 97 ........................ 100

4.5. Biological evaluation and studies for 4- $N$-alkanoyl and alkyl gemcitabine

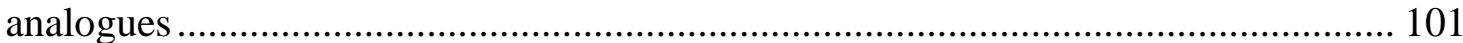

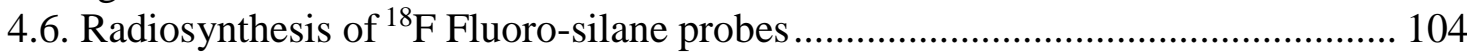

4.7. Biological and PET evaluation of $\left[{ }^{18} \mathrm{~F}\right]-4-N$-alkyl gemcitabine radioligand $96 . .111$

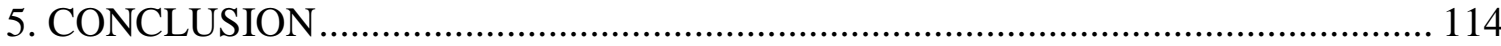

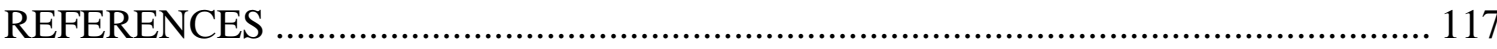

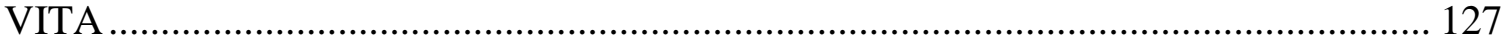




\section{LIST OF TABLES}

TABLE

PAGE

1. In vitro cytostatic activity of 4- $N$-Modified gemcitabine analogues 7-10 on the

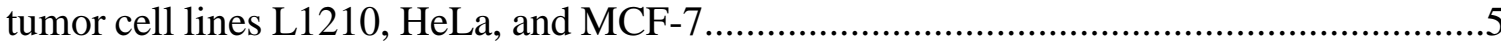

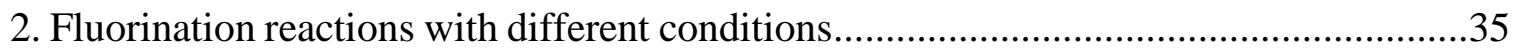

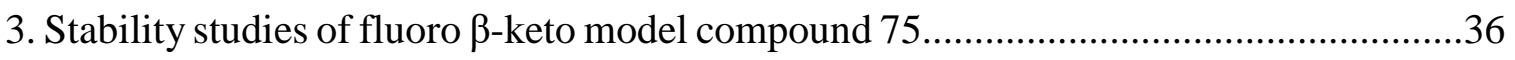

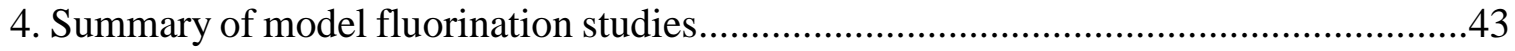

5. In vitro cytostatic activity of 4- $N$-modified gemcitabine analogues on L1210 cell line

6. ${ }^{18} \mathrm{~F}$ radiosynthetic yields of $4-N$-modified gemcitabine analogues 94 and 96 . .58

7. Effect of various reaction parameters on reduction of 97 with LTBH.........................68

8. Reduction of various sugar lactones with LTBH to lactols......................................... 71

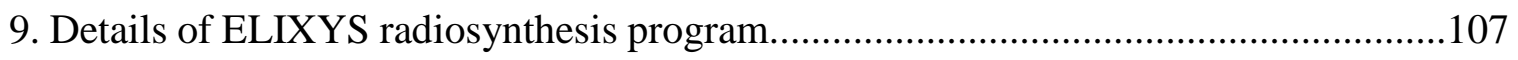

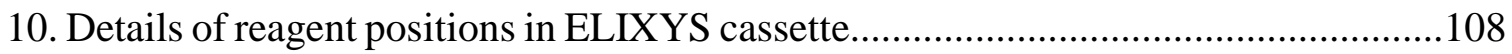




\section{LIST OF FIGURES}

FIGURE

PAGE

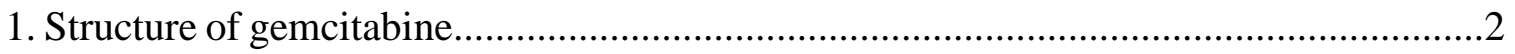

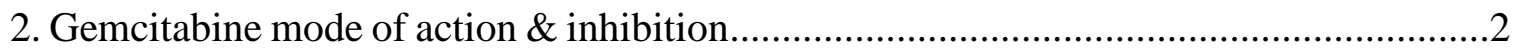

3. 4- $N$-modified gemcitabine prodrugs with enhanced anti-cancer activity......................4

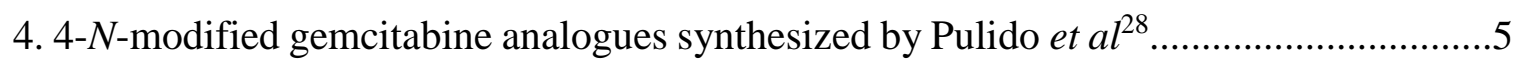

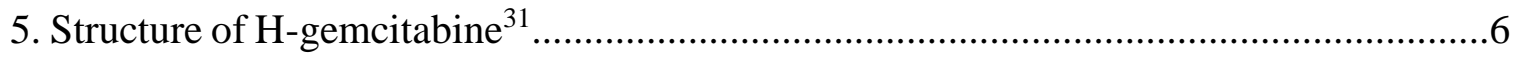

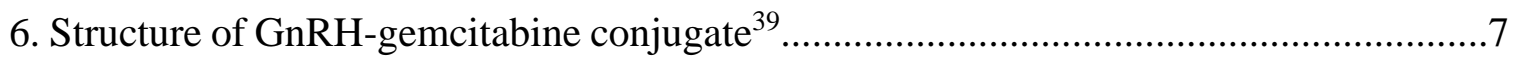

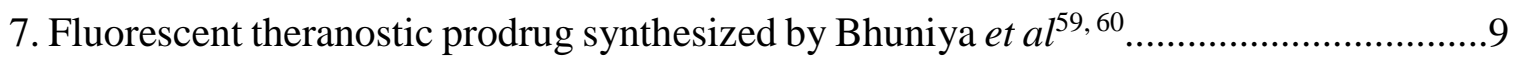

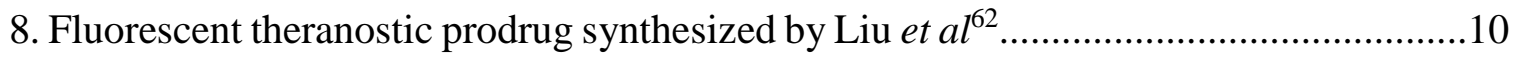

9. Examples of ${ }^{18} \mathrm{~F}$-aliphatic and aromatic nucleophilic substitutions ${ }^{71,73,74} \ldots \ldots \ldots \ldots \ldots \ldots . . .12$

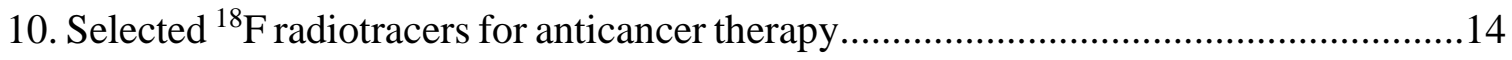

11. Hydrolysis half-lives $\left(\mathrm{t}_{1 / 2}\right)$ of selected organofluorosilanes under aqueous buffer

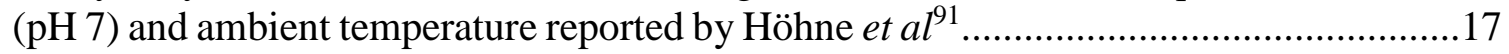

12. Silicon-fluoride acceptors in octreotate ${ }^{96} 32$ and thymidine derivatives ${ }^{99} 33 \ldots \ldots \ldots \ldots . . .19$

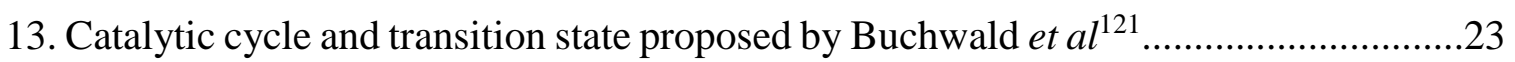

14. Proposed structures of 4- $N$-alkanoyl and 4- $N$-alkyl gemcitabine analogues................26

15. Key structural differences between $\beta$-keto A and 4- $N$-alkyl 10 gemcitabine analogues....

16. Fluorination of 4- $N$-alkyl 73 (chromatogram A: 73 standard, chromatogram B:

Crude fluorination reaction) in $50 \% \mathrm{CH}_{3} \mathrm{CN} / \mathrm{H}_{2} \mathrm{O}$.

17. Fluorination of 4- $N$-alkyl 72 (chromatogram A: 72 standard, chromatogram B:

Crude fluorination reaction) in $50 \% \mathrm{CH}_{3} \mathrm{CN} / \mathrm{H}_{2} \mathrm{O}$. .38

18. General synthetic goal of gemcitabine silicon-fluoride acceptors analogues..... 
19. Stability of 4- $N$-alkanoyl 90 (chromatogram A: 1, chromatogram B: 90 after $30 \mathrm{~min}$ ) in $35 \% \mathrm{CH}_{3} \mathrm{CN} / 0.1 \% \mathrm{TFA}$

20. Stability of 4- $N$-alkanoyl 94 (chromatogram A: 1, chromatogram B: 94 after $2 \mathrm{~h}$ ) in $35 \% \mathrm{CH}_{3} \mathrm{CN} / 0.1 \%$ TFA

21. Stability of 4-N-alkyl 92 (chromatogram A: 1, chromatogram B: 92 after $8 \mathrm{~h}$ ) in $25 \% \mathrm{CH}_{3} \mathrm{CN} / 0.1 \%$ TFA.

22. Analysis of stability of 4- $N$-alkyl 96 (chromatogram A: 96 after $1 \mathrm{~h}$, chromatogram B: 96 after $3 \mathrm{~h}$ ) in $25 \% \mathrm{CH}_{3} \mathrm{CN} / 0.1 \%$ TFA.

23. Analysis of stability of 4-N-alkyl 96 (chromatogram A: 1, chromatogram B: 96 after $3 \mathrm{~h}$ ) in $25 \% \mathrm{CH}_{3} \mathrm{CN} / \mathrm{H}_{2} \mathrm{O}$ (NO TFA).

24. In vitro cytotoxicity curve of 4- $\mathrm{N}$-alkanoyl and $4-\mathrm{N}$-alkyl gemcitabine analogues on L1210 mouse leukemic cell lines. Cells were treated with analogues for $72 \mathrm{~h}$ before the viability of treated cells was determined by MTT assay. Results represent the mean of triplicates with error bars indicating standard deviation.

25. In vitro cytotoxicity graph of 4- $N$-alkanoyl and $4-N$-alkyl gemcitabine analogues on HEK 293 cell lines. Cells were treated with analogues for $48 \mathrm{~h}$ before the viability of treated cells was determined by MTT assay. Results represent the mean of triplicates.

26. HPLC chromatograph of 86 in $20 \% \mathrm{CH}_{3} \mathrm{CN} / \mathrm{H}_{2} \mathrm{O}$

27. HPLC analysis of 86 in $\mathrm{CH}_{3} \mathrm{CN} / \mathrm{H}_{2} \mathrm{O}$ after incubation in $\mathrm{HEK} 293$ cell line (chromatogram A: cell blank, chromatogram B: supernatant after $24 \mathrm{~h}$, chromatograph $\mathrm{C}$ : cell sample after $24 \mathrm{~h}$ ) in $20 \% \mathrm{CH}_{3} \mathrm{CN} / \mathrm{H}_{2} \mathrm{O}$

28. General fluorescence labeling experiment.

29. Labeling of 86 in HEK 293 cells for 24 h, followed by fixation and addition of Fluor 488 alkyne and copper(I).

30. Macroscale radiosynthesis of 4- $N$-alkanoyl $\left[{ }^{18} \mathrm{~F}\right] 94$ (chromatogram A: UV detector, chromatogram B: radio detector, radiolabeled product in green) in $80 \%$

$\mathrm{CH}_{3} \mathrm{CN} / 0.1 \%$ TFA

31. Macroscale radiosynthesis of $4-N$-alkyl $\left[{ }^{18} \mathrm{~F}\right] 96$ (chromatogram A: UV detector, chromatogram B: radio detector, radiolabeled product in green) in $30 \% \mathrm{CH}_{3} \mathrm{CN} / \mathrm{H}_{2} \mathrm{O}$. 
32. Microscale radiosynthesis of 4- $N$-alkanoyl $\left[{ }^{18} \mathrm{~F}\right] 94$ (chromatogram A: UV detector, chromatogram $\mathrm{B}$ : radio detector, radiolabeled product in red) in $80 \% \mathrm{CH}_{3} \mathrm{CN} / 0.1 \%$ TFA.

33. Microscale radiosynthesis of 4- $N$-alkyl $\left[{ }^{18} \mathrm{~F}\right] 96$ (chromatogram A: UV detector, chromatogram B: radio detector, radiolabeled product in green) in $70 \% \mathrm{CH}_{3} \mathrm{CN} / \mathrm{H}_{2} \mathrm{O} \ldots . .61$

34. Series of frames from dynamic PET scan of WT C57BL/6 mouse injected with $\left[{ }^{18} \mathrm{~F}\right] 96$ (up to $1 \mathrm{~h}$ ). Images are coronal maximum intensity projections.

35. Series of frames from dynamic PET scan of WT C57BL/6 mouse injected with $\left[{ }^{18} \mathrm{~F}\right] 96$ (up to $1 \mathrm{~h}$ ). Images are sagittal maximum intensity projections.

36. (Left) Dynamic biodistribution of $\left[{ }^{18} \mathrm{~F}\right] 96$ in WT C57BL/6 mouse. (Right)

Maximum intensity projection at $1 \mathrm{~h}$ post-injection (left: coronal; right: sagittal)

37. (Left) Biodistribution of $\left[{ }^{18} \mathrm{~F}\right] 96$ from 10 min static scan in WT C57BL/6 mouse at $1 \mathrm{~h}$ post-injection. (Right) Maximum intensity projection of $10 \mathrm{~min}$ static scan at $1 \mathrm{~h}$ post-injection (left: coronal; right: sagittal).

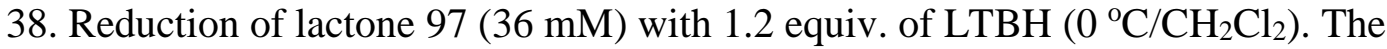
profile for the reactions was measured by integrating the peaks of the ${ }^{1} \mathrm{H}$ NMR spectra (e.g., disappearance of the $\mathrm{H} 4$ peak at $4.65 \mathrm{ppm}$ for 98 and appearance of the $\mathrm{H} 1$ peak at $5.28 \mathrm{ppm}$ for 99 ).

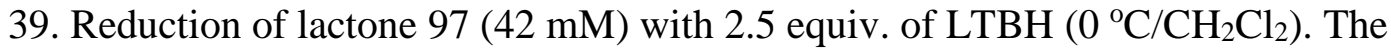
profile for the reactions was measured by integrating the corresponding peaks of the ${ }^{1} \mathrm{H}$ NMR spectra (e.g., disappearance of the $\mathrm{H} 4$ peak at $4.65 \mathrm{ppm}$ for 97 and appearance/disappearance of the $\mathrm{H} 1$ peak at $5.28 \mathrm{ppm}$ for 98 and appearance of the $\mathrm{H} 3$ peak at $4.10 \mathrm{ppm}$ for 99 ).

40. Proposed chelating of borane with exocyclic sugar oxygens........................................75

41. ${ }^{1} \mathrm{H}$ NMR spectra of reaction profile with 1.2 equiv. of LTBH...................................100

42. ${ }^{1} \mathrm{H}$ NMR spectra of reaction profile with 2.5 equiv. of LTBH...................................101

43. Schematic of the microdroplet radiosynthesis process...............................................110 


\section{LIST OF SCHEMES}

SCHEME

PAGE

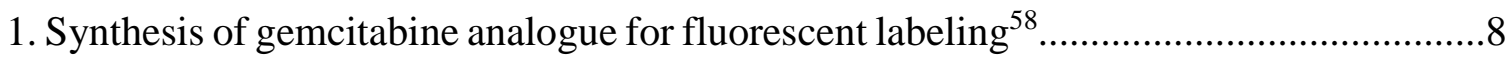

2. Deoxyfluorination of phenols and heterophenols with ${ }^{18} \mathrm{~F}$ by the Ritter group ${ }^{71} \ldots \ldots \ldots \ldots . . .13$

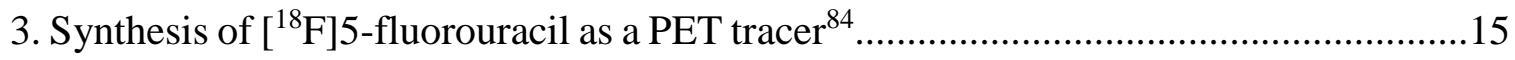

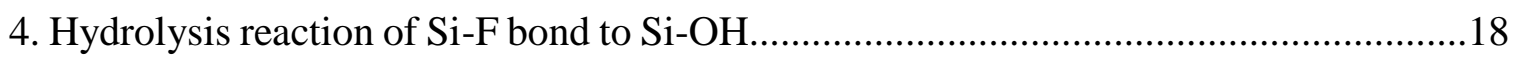

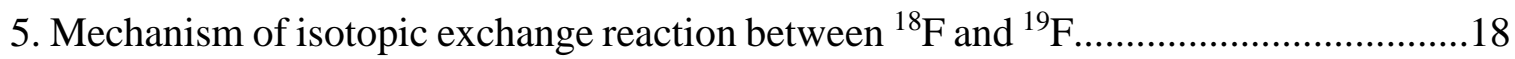

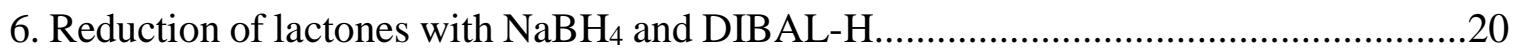

7. Synthesis of gemcitabine through reduction of sugar lactones.................................21

8. Synthesis of oxathiolanyl and dioxolanyl nucleoside analogues through reduction

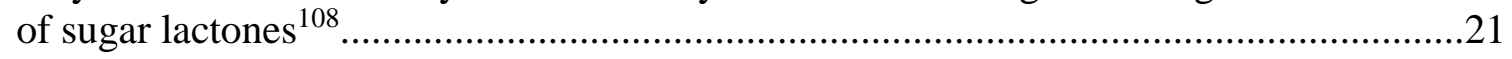

9. General and specific reduction of lactones with titanocene(III) hydride ${ }^{122} \ldots \ldots \ldots \ldots \ldots \ldots . . . .24$

10. Use of borane-based reducing agents for reduction of lactones to hemiacetals............24

11. Synthesis of cyclic azahemiacetals SRH analogues $53^{111}$, dihydroxyprolines 54

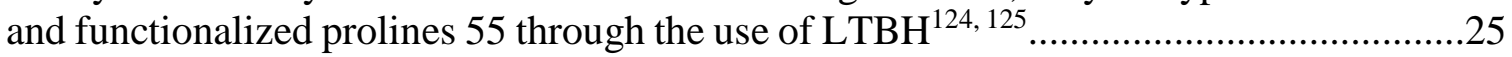

12. Reduction of sugar lactones to hemiacetals under various conditions........................27

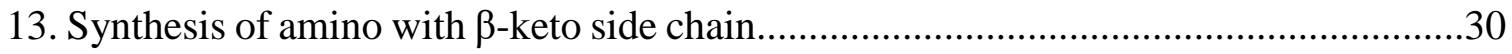

14. Unsuccessful attempted 4- $N$-tosylgemcitabine 62 and 61 coupling reaction................31

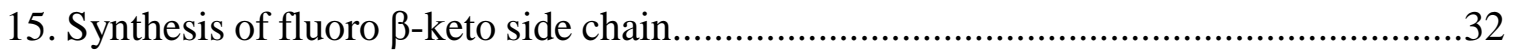

16. Overall synthesis of $4-N$-modified $\beta$-keto fluoro gemcitabine analogue.....................32

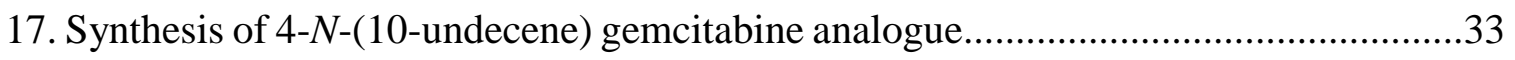

18. Overall synthesis of $\beta$-keto gemcitabine sulfonate analogue..................................34

19. Fluorination of $\beta$-keto sulfonate gemcitabine analogues and subsequent

deprotection under conditions compatible with $18 \mathrm{~F}$-radiolabeling protocols ${ }^{a}$. 


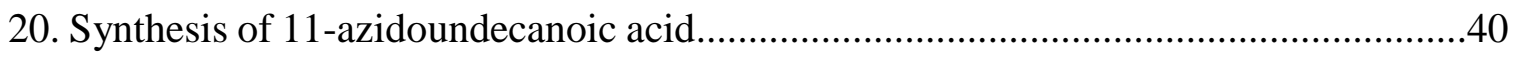

21. Synthesis of 4-N-alkanoyl gemcitabine substrates for click reactions.........................41

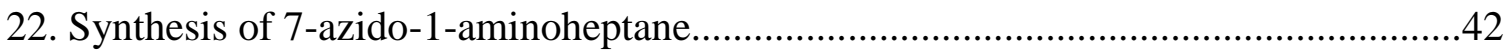

23. Synthesis of $4-N$-alkyl gemcitabine derivatives for click reactions...........................42

24. Synthesis of silane building blocks for click reactions.........................................43

25. Synthesis of the 4-N-acyl/alkyl gemcitabine analogues with the

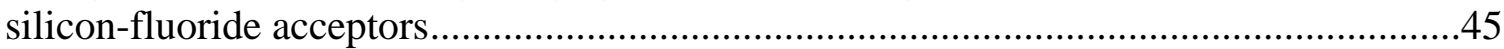

26. Radiosynthesis of $\left[{ }^{18} \mathrm{~F}\right] 4-N$-alkanoyl and alkyl gemcitabine analogues with silicon-fluoride acceptors.

27. Synthesis of 4C-SRH analogues involving reduction of ribonolactones with $\mathrm{LTBH}^{112}$ .66

28. Reduction of the protected ribono-1,4-lactone 97 with LTBH................................67

29. Reduction of $\gamma$-butyrolactone with LTBH to 1,4-butanediol......................................74 


\section{LIST OF ABBREVIATIONS}

\begin{tabular}{|c|c|}
\hline Ac & acetyl \\
\hline Ar & aromatic (NMR) \\
\hline$\beta$ & beta \\
\hline $\mathrm{Bn}$ & benzyl \\
\hline Boc & tert-buyloxycarbonyl \\
\hline BODIPY & boron-dipyrromethene \\
\hline $\mathrm{Br}$ & broad (NMR) \\
\hline $\mathrm{Bz}$ & benzoyl \\
\hline calcd & calculated (HRMS) \\
\hline $\mathrm{CDA}$ & cytidine deaminase \\
\hline${ }^{\circ} \mathrm{C}$ & degrees Celsius \\
\hline $\mathrm{Ci}$ & Curie(s) \\
\hline $\mathrm{d}$ & doublet (NMR) \\
\hline DAST & diethylaminosulfur trifluoride \\
\hline $\mathrm{dCK}$ & deoxycytidine kinase \\
\hline DCM & dichloromethane \\
\hline $\mathrm{dFdC}$ & 2',2'-difluoro-2'-deoxycytidine \\
\hline $\mathrm{dFdCMP}$ & 2',2'-difluoro-2'-deoxycytidine monophosphate \\
\hline $\mathrm{dFdCDP}$ & 2',2'-difluoro-2'-deoxycytidine diphosphate \\
\hline $\mathrm{dFdCTP}$ & 2',2'-difluoro-2'-deoxycytidine triphosphate \\
\hline $\mathrm{dFdU}$ & $2^{\prime}, 2^{\prime}$-difluorouridine \\
\hline DIBAL-H & diisobutylaluminium hydride \\
\hline
\end{tabular}




\begin{tabular}{|c|c|}
\hline DIPEA & $N, N$-diisopropylethylamine \\
\hline DMAP & 4-dimethylaminopyridine \\
\hline DMF & $N, N$-dimethylformamide \\
\hline DMSO & dimethylsulfoxide \\
\hline EDC & ( $N$-dimethylaminopropyl)- $N$ '-ethyl-carbodiimide \\
\hline ESI & electrospray ionization \\
\hline FAC & 2'-deoxy-2'-fluoro- $\beta$-D-arabinofuranosyl \\
\hline FDG & 2-deoxy-2-fluoro- D-glucose \\
\hline $\mathrm{g}$ & $\operatorname{gram}(\mathrm{s})$ \\
\hline $\mathrm{h}$ & hour(s) \\
\hline hENT & human equilibrative nucleoside transporter \\
\hline $\mathrm{HOBt}$ & hydroxybenzotriazole \\
\hline HPLC & high performance liquid chromatography \\
\hline HPMA & $N$-(2-hydroxypropyl)methacrylamide \\
\hline HRMS & high resolution mass spectroscopy \\
\hline $\mathrm{Hz}$ & hertz \\
\hline $\mathrm{IC}_{50}$ & half maximum inhibitory concentration \\
\hline ID & injected dose \\
\hline$J$ & coupling constant in $\mathrm{Hz}$ (NMR) \\
\hline $\mathrm{K}_{222}$ & Kryptofix 222 \\
\hline $\mathrm{L}$ & liter(s) \\
\hline LTBH & lithium triethylborohydride \\
\hline
\end{tabular}




\begin{tabular}{|c|c|}
\hline $\mathrm{m}$ & milli; multiplet (NMR) \\
\hline M & moles per liter \\
\hline $\min$ & minute(s) \\
\hline mol & $\operatorname{mole}(\mathrm{s})$ \\
\hline Ms & mesyl \\
\hline MS & mass spectrometry \\
\hline$m / z$ & mass to charge ratio (MS) \\
\hline NFSi & $N$-fluorobenzenesulfonimide \\
\hline NMO & methylmorpholine $N$-oxide \\
\hline NMR & nuclear magnetic resonance \\
\hline$p$ & para \\
\hline PMMA & poly(methyl methacrylate) \\
\hline PEG & polyethylene glycol \\
\hline PET & positron emission tomography \\
\hline PTC & phase transfer catalyst \\
\hline pyr & pyridine \\
\hline$\%$ & percentage \\
\hline q & quartet (NMR) \\
\hline QMA & quarternary methylammonium \\
\hline quin & quintet (NMR) \\
\hline $\mathrm{RCY}$ & radiochemical yield \\
\hline RNR & ribonucleotide reductase \\
\hline $\mathrm{RP}$ & reverse phase (HPLC) \\
\hline
\end{tabular}




\begin{tabular}{|c|c|}
\hline $\mathrm{rt}$ & room temperature \\
\hline $\mathrm{s}$ & second(s); singlet (NMR) \\
\hline SPAAC & strain-promoted alkyne-azide cycloadditions \\
\hline SRH & $S$-ribosylhomocysteine \\
\hline $\mathrm{t}$ & triplet (NMR) \\
\hline TBAF & tetra- $n$-butylammonium fluoride \\
\hline TBDMS & tert-butyldimethylsilyl \\
\hline$t-\mathrm{Bu}$ & tert-butyl \\
\hline TEA & trimethylamine \\
\hline TFA & trifluoroacetic acid \\
\hline THF & tetrahydrofuran \\
\hline TK & thymidine kinase \\
\hline TLC & thin layer chromatography \\
\hline TMS & trimethylsilyl \\
\hline$t_{R}$ & retention time (HPLC) \\
\hline TPP & tetraphenylporphyrin \\
\hline Ts & tosyl \\
\hline$\mu$ & micro \\
\hline UV & ultraviolet \\
\hline VIS & visible \\
\hline
\end{tabular}




\section{INTRODUCTION}

\subsection{Gemcitabine: Chemistry and biological activity}

\subsubsection{Gemcitabine: Anti-cancer mechanism of action and inhibition}

Gemcitabine $\left(2^{\prime}, 2^{\prime}\right.$-difluoro-2'-deoxycytidine, $\mathrm{dFdC}$, Figure 1$)$ is a chemotherapeutic cytidine analogue that is usually used as first-line therapy for pancreatic and non-small cell lung cancers. ${ }^{1,2}$ The analogue was first synthesized by Hertel et al. in 1988., 4 Gemcitabine, like most nucleoside analogues, is hydrophilic, and its uptake across the cell membrane is facilitated by human equilibrative nucleoside transport proteins (hENT's). ${ }^{5}$ Once in the cell, gemcitabine is activated by deoxycytidine kinase (dCK) for monophosphorylation, which is its rate limiting step, and then subsequent phosphorylation by intracellular kinases to its di- and and tri-phosphate forms ( $\mathrm{dFdCDP}$ and $\mathrm{dFdCTP}$ ). The triphosphate, dFdCTP, is then incorporated into DNA, inhibiting DNA polymerase by chain termination during replication and repair processes, triggering apoptosis. ${ }^{6-10}$ Also, the potentiation of the effects of the triphosphorylated gemcitabine results from its inhibition of ribonucleotide reductase(s) (RNR's). Ribonucleotide reductases are enzymes that are involved in the conversion of nucleoside diphosphates to deoxynucleoside 5'-

diphosphates (dNDPs) (Figure 2) ${ }^{11-13}$ The inhibition of RNR's is critical because it leads to a reduction in dNDPs and consequently to a reduction in dNTPs. The change in concentration of dNTPs reduces the competition for $\mathrm{dFdCTP}$ to become incorporated into DNA by DNA polymerase, increasing the chance of apoptosis. 


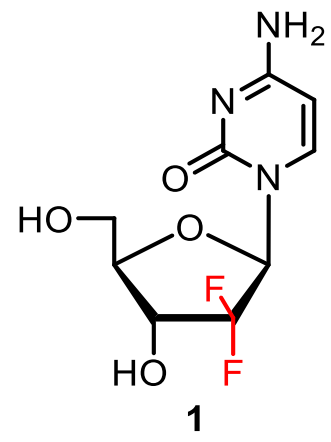

Figure 1. Structure of gemcitabine $(\mathrm{dFdC})$

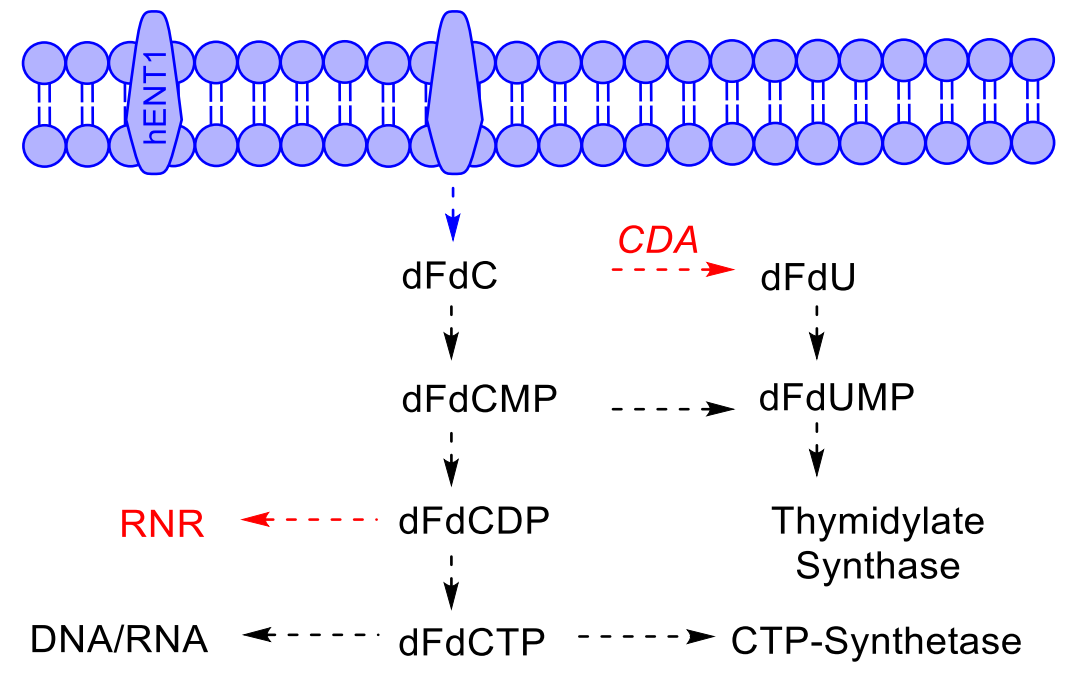

Figure 2. Gemcitabine (dFdC) mode of action \& inhibition

Even though, the mechanism of gemcitabine has shown to be effective against a variety of tumor types, the efficacy of gemcitabine is diminished because of a variety of issues. ${ }^{8}$, ${ }^{14}$ Gemcitabine, or Gemzar ${ }^{\circledR}$ as it is known in the market, in its current form, is introduced into the body by intravenous infusion, and studies have shown that it is the optimal way for the drug to be administered. ${ }^{15}$ High-dose oral gemcitabine is cytotoxic, causing serious liver and gastrointestinal problems. ${ }^{16,17}$ Studies have shown that gemcitabine, because it is hydrophilic, is excreted $(>90 \%)$ in the urine. Gemcitabine also undergoes quick deamination into the inactive metabolite $2^{\prime}, 2^{\prime}$-difluorouridine ( $\mathrm{dFdU}$ ) by cytidine deaminase (CDA), the enzyme which converts the cytosine base to a uracil base. ${ }^{18}$ The 
transformation occurs in both the plasma and in the tissues, and it has shown to be a significant disadvantage for the potency of the drug.

\subsubsection{Gemcitabine: Design and synthesis of prodrugs}

In order to tackle these various issues, prodrug strategies have been developed featuring acyl modifications of different lengths on either the exocyclic 4- $N$-amine or on the hydroxyl groups of the sugar at the $3^{\prime}$ or $5^{\prime}$ carbon. ${ }^{19-22}$ These modifications have been extensively studied because, first, the addition of a lipophilic chain to gemcitabine has shown to facilitate the incorporation of the drug into cells. Second, once in the cell, the hydrolyzable acyl/amide modifications have shown to facilitate a slow conversion to the parent drug, gemcitabine. The modification increases the drug's bioavailability and uptake while also providing prolonged resistance to deamination by CDA as acyl groups are not

natural substrates for the enzyme. ${ }^{23}$ A few examples of these type of modifications include 4- $N$-stearoyl, 4- $N$-squalenoyl, and other 4- $N$-alkanoyl gemcitabine prodrugs e.g., 3-4

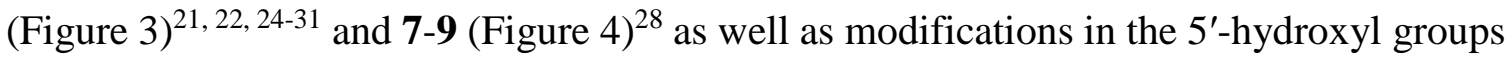
(e.g. CP -4126, 2). ${ }^{19,}$ 29, 32-34 These designed modifications are considered the first generation of prodrugs for gemcitabine. Many of the synthesized analogues have been extensively studied in cancer cell lines as well as mice models, with the main goal of improving the overall efficacy of gemcitabine. One of these examples is LY2334737, 5, a prodrug designed by McCarthy et al. ${ }^{21}$ This prodrug was shown to be stable between $\mathrm{pH}$ 4-8, and its dose resulted in prolonged gemcitabine exposure and slow deamination. Since its initial synthesis in 2009, this prodrug has undergone several pharmacokinetic evaluations, including phase 1 studies. ${ }^{35-37}$ 


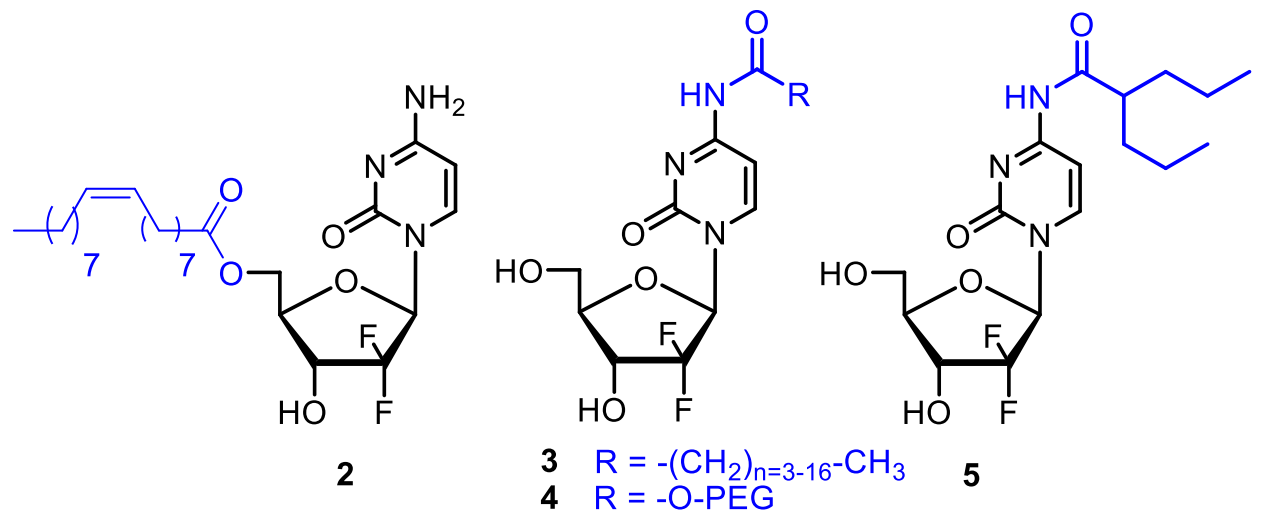

Figure 3. 4- $N$-modified gemcitabine prodrugs with enhanced anti-cancer activity

The Wnuk research group has also been interested in the synthesis of modified gemcitabine analogues. $^{28,} 38$ Following the same design strategy of 1) increased lipophilicity, 2) slow hydrolysis to the parent drug and 3) slow deamination by CDA to inactive dFdU, Pulido et al. synthesized a series of 4- $N$-alkanoyl (acyl) 6-8 and alkyl gemcitabine analogues 9-10 (Figure 4) and had their cellular inhibition assessed on a panel of murine and human tumor cell lines (Table 1). Their findings correlated with previous studies on other 4- $N$-alkanoyl modified gemcitabine analogues. Their 4-N-alkanoyl analogues showed potent anti-proliferative activities with nanomolar range $\mathrm{IC}_{50}$ values $(0.0077-0.053 \mu \mathrm{M})$. However, the synthesized 4- $N$-alkylgemcitabine analogues showed only modest $\mathrm{IC}_{50}$ values $(17-29 \mu \mathrm{M})$. The low $\mathrm{IC}_{50}$ values was hypothesized to be associated with their to low cellular uptake as well as low conversion to gemcitabine, which was shown by stability studies in rodent liver extract in PBS. 

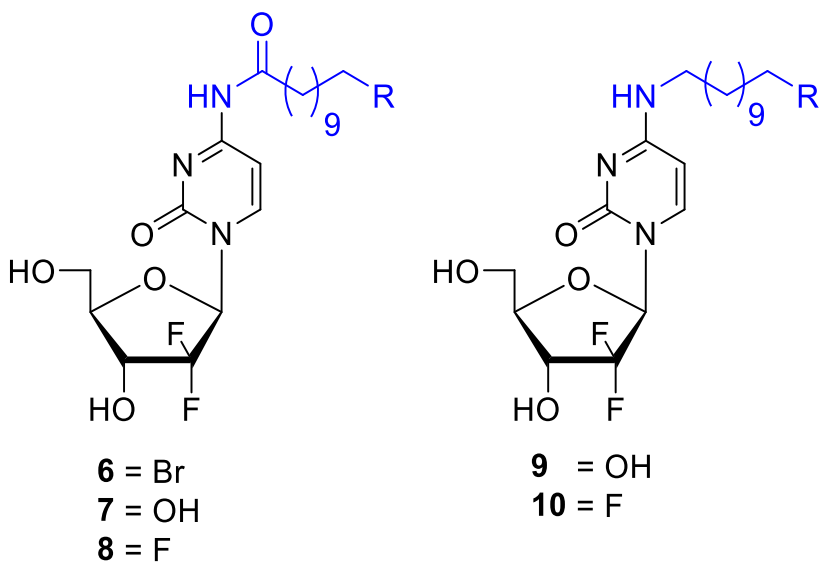

Figure 4. 4- $N$-modified gemcitabine analogues synthesized by Pulido et ${ }^{28}$

Table 1. In vitro cytostatic activity of 4- $\mathrm{N}$-Modified gemcitabine analogues 7-10 on the tumor cell lines L1210, HeLa, and MCF-7 ${ }^{28}$

\begin{tabular}{cccc}
\hline Gemcitabine & \multicolumn{3}{c}{ IC $\mathbf{5 0}(\boldsymbol{\mu M})$} \\
\cline { 2 - 4 } analogue & $L 1210$ & HeLa & $M C F-7$ \\
$\mathbf{7}$ & 0.023 & 0.049 & 0.0081 \\
$\mathbf{8}$ & 0.053 & 0.011 & 0.0077 \\
$\mathbf{9}$ & 29 & 22 & 27 \\
$\mathbf{1 0}$ & 28 & 17 & 26 \\
\hline
\end{tabular}

To my knowledge, the synthesis and biological properties of 4 - $\mathrm{N}$-alkylgemcitabine analogues have not been intensively explored. However, because of their stability and permanent presence of $4-\mathrm{N}$-alkyl chain, they can be candidates for use as ${ }^{18} \mathrm{~F}$-PET radiotracers and metabolic labeling.

\subsubsection{Gemcitabine: Theranostic image-guided tumor agents}

Using the above prodrug designs as foundation, the next generation of gemcitabine prodrugs are being designed through a theranostic approach, the combination of diagnostic and therapeutic entities into one drug delivery system. These prodrugs have two goals: 1) increase the bioavailability of the drug and 2) provide increased specificity to the tumors being targeted. Approaching the same idea of acyl modification, one example is $\mathrm{H}$ - 
gemcitabine (11; Figure 5), the 4- $N$-alkanoyl gemcitabine prodrug contains the Hoechst group, an extracellular DNA (E-DNA) targeting moiety, as a well as a disulfide bond as an additional triggering mode of action. The Hoechst moiety binds to the E-DNA present in the core of the tumors and the disulfide bond provides a second mode of release, increasing the prodrug's time to accumulate within the tumors. ${ }^{31} \mathrm{H}$-gemcitabine then provides not only provides increased bioavailability, it also provides increased specificity to tumors with E-DNA present. The analogue H-gemcitabine also showed similar toxicity to gemcitabine. The use of disulfide bonds is also used in other gemcitabine prodrug strategies that will be discussed later in this section.

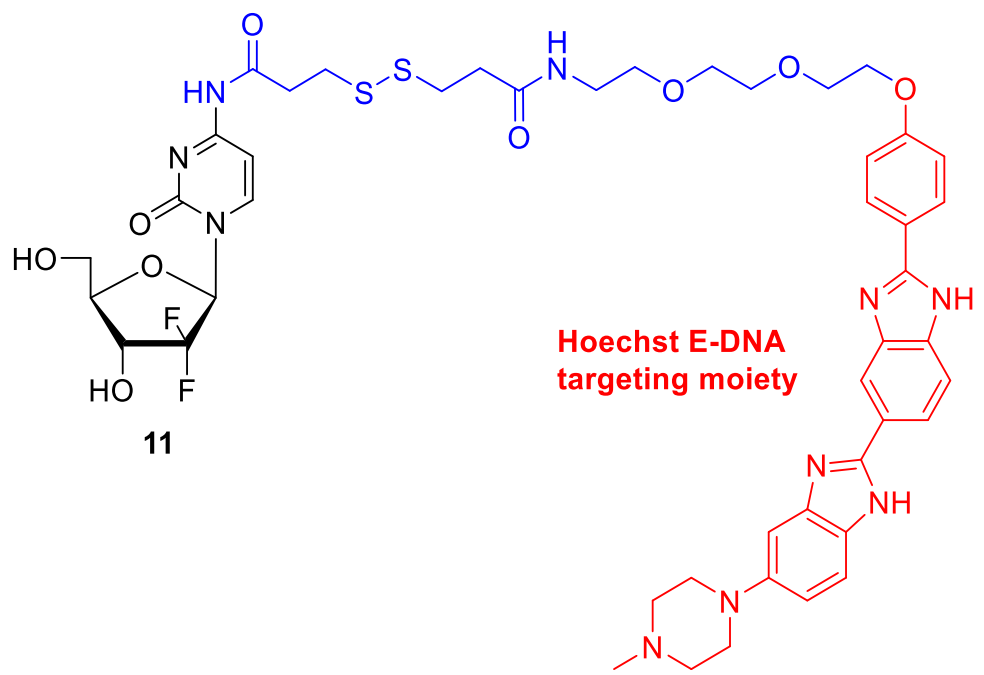

Figure 5. Structure of H-gemcitabine $\mathrm{e}^{31}$

Another approach that has been explored is the design and synthesis of gemcitabine conjugates with receptor binding peptides for targeted delivery to specific tumors. One such example is the GnRH-gemcitabine conjugates. They have been designed to contain Gonadotropin-releasing hormone $(\mathrm{GnRH})$ specific amino acids conjugated to a linker moiety attached to $5^{\prime}$ of the sugar of gemcitabine (12; Figure 6$) .{ }^{39}$ The incorporation of the 
GnRH ligand was chosen because prostate cancer tumors have shown to overexpress GnRH receptors. The conjugates were then able to provide specific target and increased bio-distribution with potent anti-cancer activity.

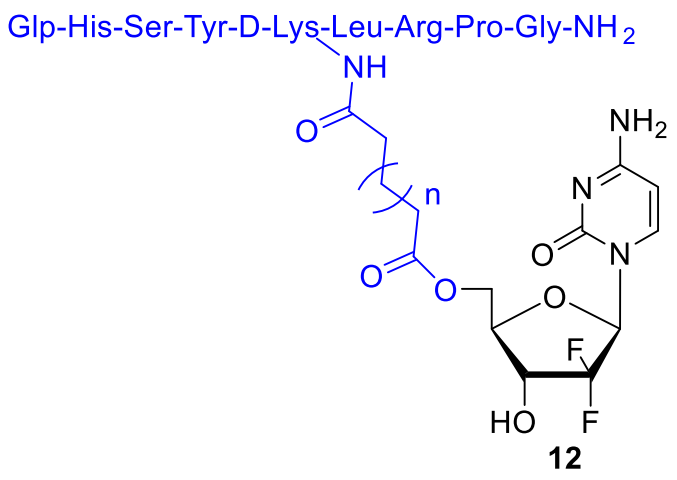

Figure 6. Structure of GnRH-gemcitabine conjugate ${ }^{39}$

Another route of increasing the effectiveness of gemcitabine has been through the synthesis of nanoparticles. ${ }^{40}, 41$ Wang et al. synthesized gemcitabine-poly(methyl methacrylate) (Gem-PMMA) conjugated amphiphiles. ${ }^{42}$ The amphiphiles can selfassemble to form nanoscale aggregates in an aqueous environment. These nanoparticles provide high drug payload by having a controlled release. Another route that has been studied is the synthesis of copolymer and carbon nanotubes-drug conjugates containing gemcitabine. ${ }^{43-45} \mathrm{Hu}$ et al. used gemcitabine as part of the synthesis of an azido-carbonate monomer, 2,2-bis(azidomethyl)trimethylene carbonate, which was then reacted with alkynyl compounds via click chemistry had then gemcitabine was conjugated to it. ${ }^{43}$ In a similar project, Kopecek at al. synthesized degradable HPMA copolymer-drug conjugates containing gemcitabine for studies with human ovarian carcinoma cells. ${ }^{44}$

Some of the example prodrugs described above have been synthesized using click chemistry, ${ }^{46-49} 50,51$ through the use of copper catalyst as well as cyclooctyes (SPAAC). 
Click chemistry in nucleosides and oligonucleotides, with terminal alkyne or azide has been reviewed extensively. ${ }^{52-55}$ These modifications have been done both at the heterocyclic base and the sugar, which then have been conjugated with modified fluorescent dyes, sugars and peptides for imaging and drug discovery. ${ }^{53,}$ 55-57 The exploration of click chemistry in gemcitabine and its analogues is fairly recent.

Another route of click chemistry that needs mentioning is the use of gemcitabine and its analogues for imaging purposes. Luedtke et al. synthesized the metabolite 2',2'-difluoro analog of 5- ethynyluridine $\mathbf{1 3}$ to achieve pathogen-selective labeling as this analogue is selectively metabolized in HSV-1 infected cells owing to the expression of a viral thymidine kinase (TK). The analogue bearing a terminal alkyne was then with treated with $\mathrm{CuI}$ and an azide-conjugated fluorophore to give fluorescent analogue 14, for the visualization of cells that contained the HSV-1 infection but not uninfected cells (Scheme 1). ${ }^{58}$

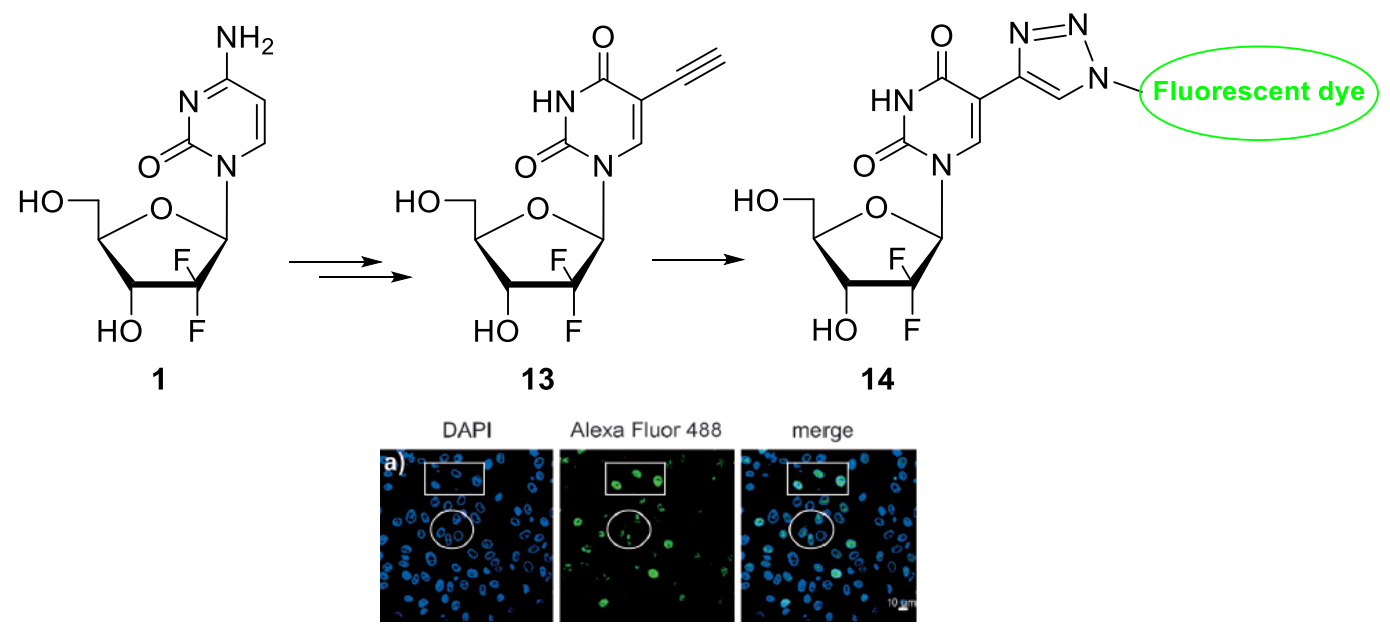

Scheme 1. Synthesis of gemcitabine analogue for fluorescent labeling ${ }^{58}$

Additionally, extensive work has been done in the area of the synthesis of gemcitabine prodrugs with fluorescent conjugates with imaging capabilities. ${ }^{59}$ The Kim group has 
synthesized a series of theranostic gemcitabine (through $\mathrm{C}^{\prime}$ ) prodrugs that contain fluorophores connected via a disulfide bond and with biotin/folate through click chemistry to monitor drug delivery. ${ }^{60,61}$ One of these prodrugs contained Coumarin as their fluorophore (not pictured) and another gemcitabine prodrug, 15, with the near IR fluorescing BODIPY fluorophore. Another set of analogues contained heptamethine cyanine dyes with folate. ${ }^{62}$ In all the analogues synthesized, the disulfide bond is cleaved intracellularly by thiols, followed by hydrolysis of the ester moieties to release gemcitabine and the fluorophore. Once released from gemcitabine, the fluorophores have stronger fluorescence than when conjugated (Figure 7). The intake of gemcitabine by cells was shown by fluorescence studies of the prodrug in the presence and absence of dithiothreitol (DTT), a well-known reducing agent. The conjugates showed targeted cellular differentiation by its incorporation in biotin/folate-receptor positive tumor cells.

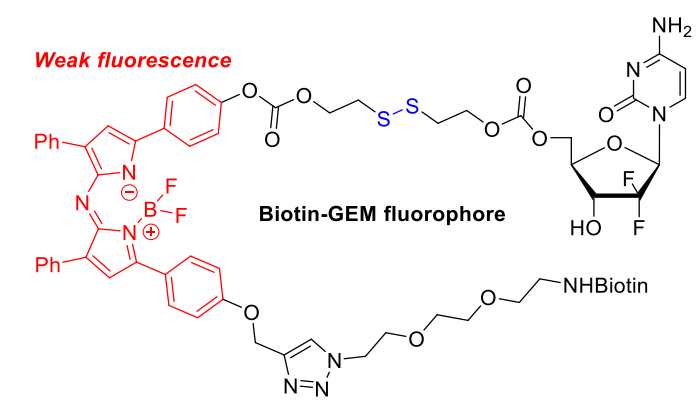

15

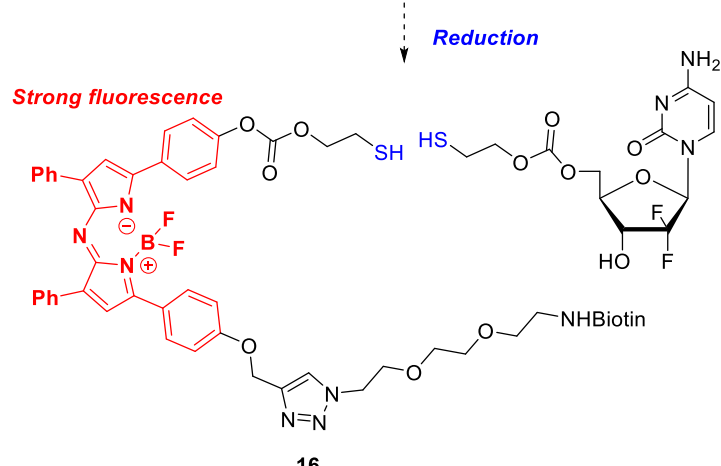

16

Figure 7. Fluorescent theranostic prodrug synthesized by Kim group ${ }^{60,61}$ 
Liu and coworkers also worked in a similar near infrared activable mesotetraphenylporphyrin (TPP) prodrug of gemcitabine with image-guided in situ tumor photodynamic therapy capability known as TPP-L-GEM (Figure 8). Mesotetraphenylporphyrin is a singlet oxygen $\left({ }^{1} \mathrm{O}_{2}\right)$ generator and the present thioketal linker is ${ }^{1} \mathrm{O}_{2}$ sensitive. The release of gemcitabine was triggered by the low energy red light induced ${ }^{1} \mathrm{O}_{2}$ generation in TPP followed by the ${ }^{1} \mathrm{O}_{2}$ mediated thioketal cleavage. ${ }^{63}$
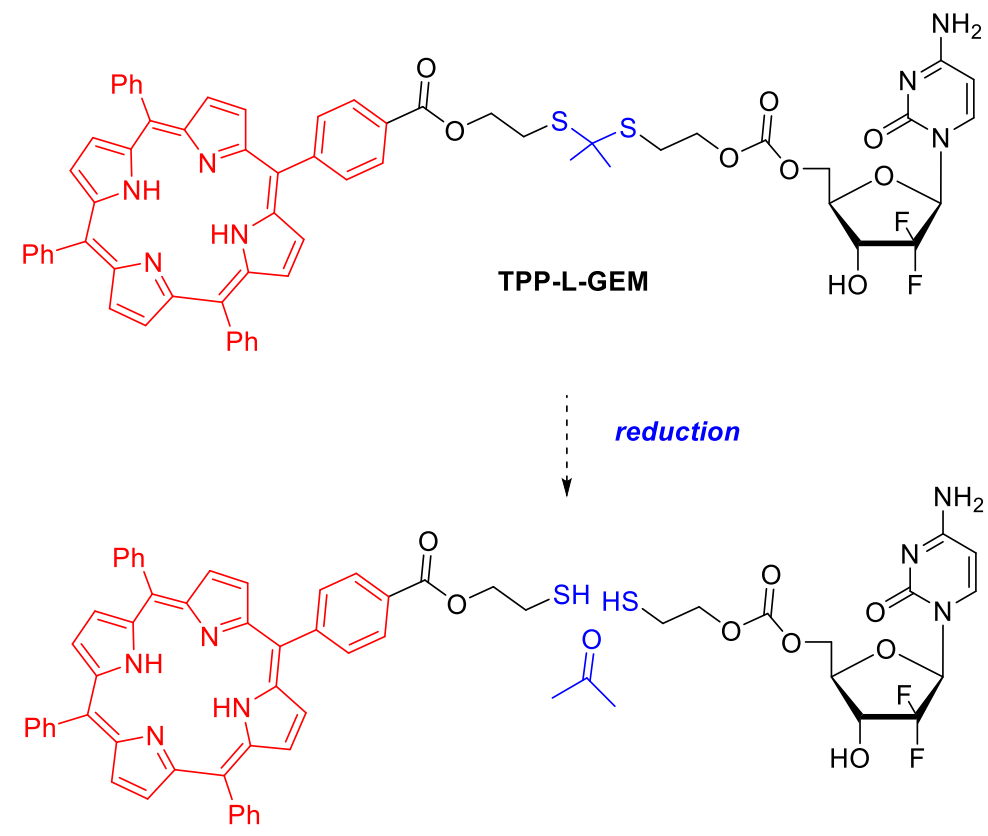

Figure 8. Fluorescent theranostic prodrug synthesized by Liu et al. ${ }^{63}$

As discussed above, many strategies have been developed to increase gemcitabine's efficacy. Many of these strategies involve imaging capabilities, with protocols that are still in the beginning stages of development, but it shows that combinational protocols are key in understanding and advancing drug discovery. Another useful tool that we shall focused on is the use of Positron Emission Tomography (PET) as a means of theranostic imaging. 


\subsection{Positron emission tomography (PET)}

Positron emission tomography (PET) is recognized as an important tool in modern imaging. This imaging technique uses a positron emitting radionuclide (such as fluorine18). The radionuclide, once emitting, travels through the tissue and it comes to rest to disintegrate with emission of two diametrically opposed gamma rays of $511 \mathrm{keV}$. These

created gamma rays are then detected and used for reconstruction of a 3D image. ${ }^{64,65}$ The imaging technique has been used for cancer detection, metabolic disorders and cardiovascular disease among other utilizes. Fluoride-18 $\left({ }^{18} \mathrm{~F}\right)$ is commonly used as a radionuclide to provide PET images of high resolution, as it has a low positron energy of $640 \mathrm{keV}$ and a half-life of 109 minutes. The main focus of the use of ${ }^{18} \mathrm{~F}$ is its introduction to molecules for biological purposes. The generation of ${ }^{18} \mathrm{~F}$ is through a cyclotron that produces it by bombarding $\mathrm{H}_{2}{ }^{18} \mathrm{O}$ enriched water with protons to initiate a reaction that converts the ${ }^{18} \mathrm{O}$ atom into a ${ }^{18} \mathrm{~F}$ atom. ${ }^{66,67}$

\subsubsection{Radiochemistry: Fluorination}

As mentioned previously, fluoride-18 has been shown to be the optimal atom for PET imaging. The radiouclide is greatly used due to its half-life of $109.8 \mathrm{~min}$ compared to other atoms such as ${ }^{15} \mathrm{O}$ and ${ }^{11} \mathrm{C}$ have half-lives of 2.037 and 20.38 respectively. Also, fluorine has favorable physical properties, such as small van der Waals radius (1.47 $\AA$ ), high electronegativity, and strong bond formation with carbon with $\mathrm{C}-\mathrm{F}$ energy bond of 112 $\mathrm{kcal} / \mathrm{mol}$, making the bond more thermally stable and oxidation resistant, which are key for PET imaging. ${ }^{68,69}$

Because of these characteristics, many nucleophilic and electrophilic fluorination reagents have been studied but only a few are used in $18 \mathrm{~F}$ fluorination available in the 
market. Examples of nucleophilic fluorination reagents include KF, TBAF, DAST, PhenoFluor and Deoxo-fluor. Electrophilic reagents include NFSi and SelectFluor. Furthermore, there is a difference in nucleophilic aliphatic versus nucleophilic aromatic substitutions with fluorinating reagents. ${ }^{70,71}$ Additionally, these substitutions are aided by the use of phase transfer catalysts (PTC). Kryptofix 222 and 18-Crown-6 are PTCs that enhance the solubility and nucleophilicity of the fluoride ion by complexing with the cation, usually potassium. ${ }^{72}$
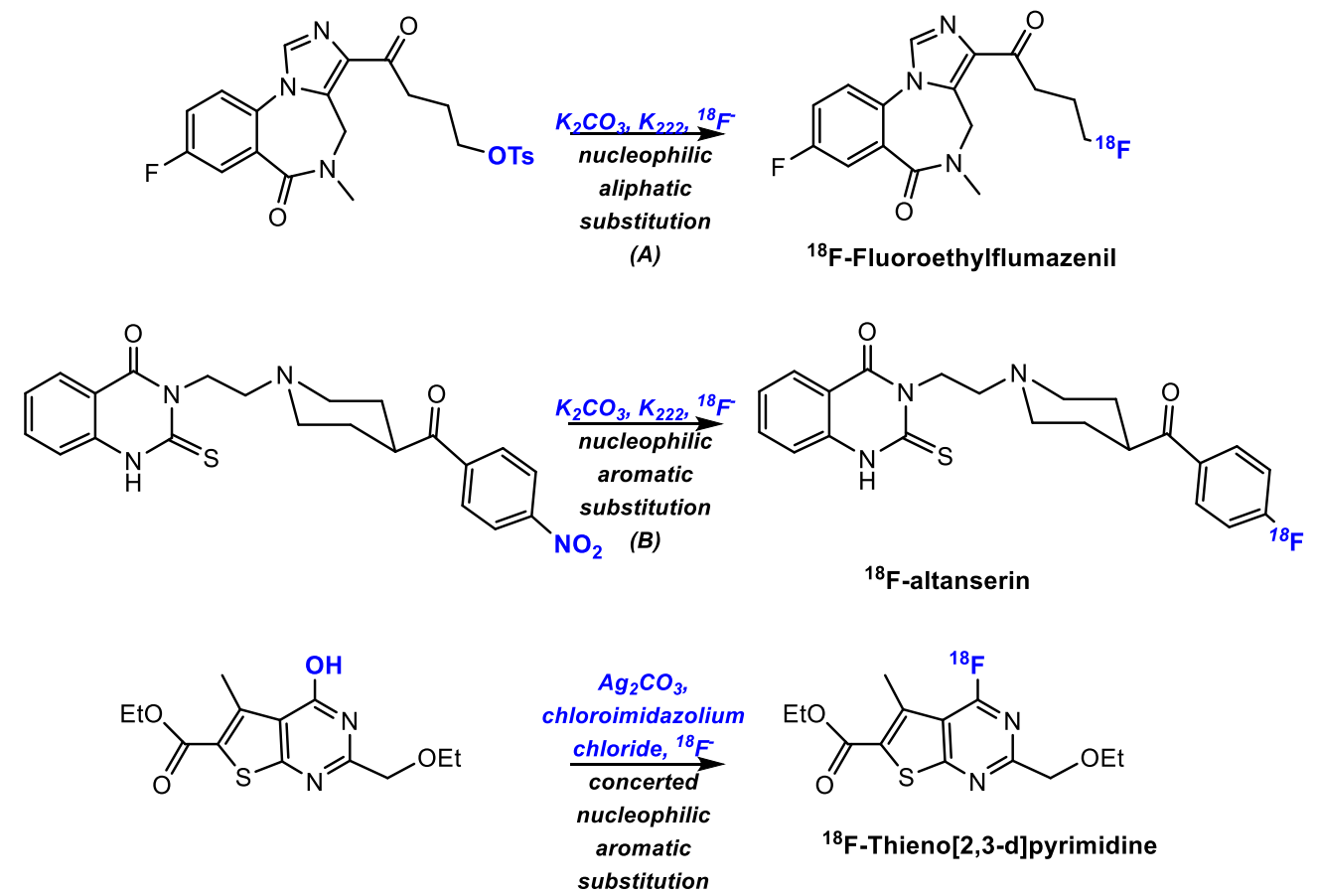

(C)

Figure 9. Examples of ${ }^{18} \mathrm{~F}$-aliphatic and aromatic nucleophilic substitutions ${ }^{71,73,74}$

Nucleophilic aliphatic substitutions (Figure 9, A) are $\mathrm{S}_{\mathrm{N}} 2$ type reactions where fluorine substitutes a leaving group. In the case for the substrates for PET imaging, the specific leaving group used is important depending on the reactivity and stability of the substrate. These aliphatic substitutions usually involve the use tosylates and mesylates with KF as the fluorine sources. Aromatic nucleophilic substitutions $\left(\mathrm{S}_{N} \mathrm{Ar}, \mathrm{B}\right)$ require electron 
withdrawing group in the ortho/para position, which act as activators in these types of substitutions as well as polar aprotic solvents and high temperatures $\left(100^{\circ} \mathrm{C}\right.$ or greater). These reactions occur through addition-elimination or elimination-addition mechanisms with the formation of highly reactive Meisenheimer intermediates. One example is the Balz-Schiemann reaction, which involves a diazotization, followed by thermal decomposition of the derived tetrafluoroborate. Overall, extensive work has been done in studying these type of substitution reactions with all the focused on the carbon-fluoride bond.

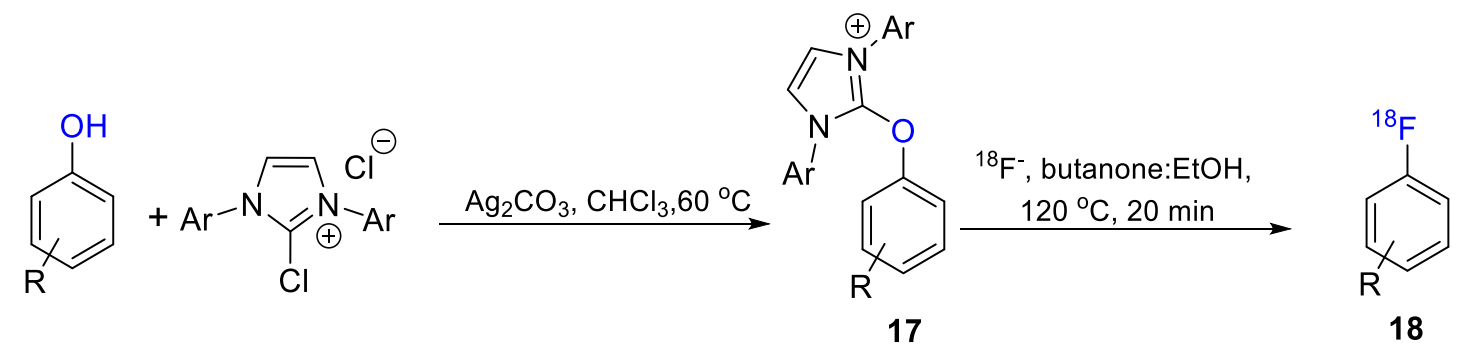

Scheme 2. Deoxyfluorination of phenols and heterophenols with ${ }^{18} \mathrm{~F}$ by the Ritter group ${ }^{71}$

The Ritter group showed that nucleophilic substitution to be used with ${ }^{18} \mathrm{~F}$ can be done through a concerted mechanism $\left(\mathrm{CS}_{\mathrm{N}} \mathrm{Ar}, \mathrm{C}\right)$ through the deoxyfluorination reaction of phenols with the reagent PhenoFluor with both electron-rich and electron-poor substrates on the ring. ${ }^{71}$ The substitution yields an imidazolum intermediate, $\mathbf{1 7}$, that undergoes a fluoride attack to give a tetrahedral intermediate followed by a concerted displacement on the arene (Scheme 2). Ritter's method works with heterocycles which are present in many bioactive compounds that are often problematic in regular $\mathrm{S}_{\mathrm{N}} \mathrm{Ar}$ conditions.

\subsubsection{Positron emitting ${ }^{18} \mathrm{~F}$ radiotracers for anticancer therapy}

Positron Emission Tomography imaging is becoming a great tool for the imaging of different types of small molecules. ${ }^{75,76}$ The most extensively used radiotracer is 2-deoxy- 
2-[fluorine-18]fluoro- D-glucose $\left(\left[{ }^{18} \mathrm{~F}\right]-\mathrm{FDG}, 19\right)$. The analogue of glucose provides valuable functional information on the basis of the increased glucose uptake and glycolysis of cancer cells and the method depicts metabolic abnormalities. The glucose analogue's ability to detect tumors depends on various factors, such as their size, metabolic activity, and distribution in some normal tissues which can affect the tumor to surrounding background ratio (Figure 10). ${ }^{64,} 77$ Other well studied compounds include ${ }^{18}$ F-FluoroLdihydroxyphenylamine $\left({ }^{18} \mathrm{~F}\right.$-fluoro-L-DOPA, 20) which is used to evaluate the in vivo activity of aromatic L-amino acid decarboxylase of dopaminergic system. ${ }^{78}$ A structural analogue of 5 - $\alpha$-dihydrotestosterone, ${ }^{18} \mathrm{~F}$-16 $\beta$-Fluoro-5 $\alpha$-dihydrotestosterone (FDHT, 21), can be useful to detect metastatic and recurrent prostate cancer lesions, binding affinity and selectivity for androgen receptors ${ }^{79}$ and ${ }^{18}$ F-3-Fluoro-3-deoxy-thymidine ([18F]-FLT, 22) is a pyrimidine analogue that reveals the activities of thymidinekinase- 1 during the phase S of mitoses. ${ }^{76,80}$

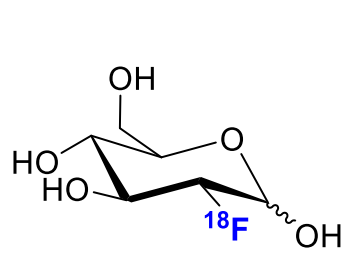

19<smiles>N[C@@H](Cc1cc(O)c(O)cc1F)C(=O)O</smiles>

20

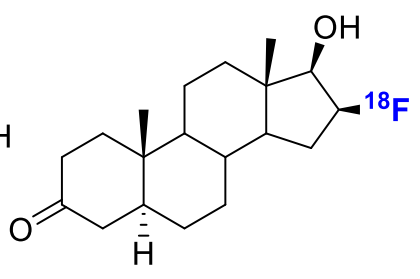

21
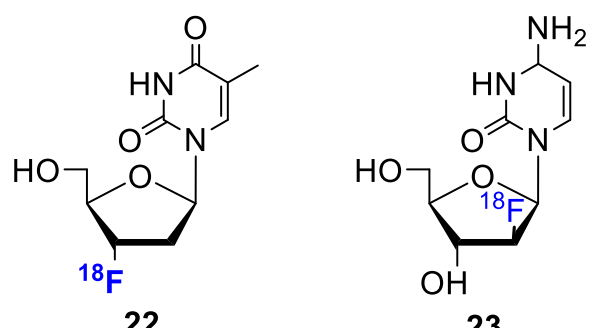

23

Figure 10. Selected ${ }^{18} \mathrm{~F}$ radiotracers for anticancer therapy

Radu et al. developed 1-(2'-Deoxy-2'-18F-fluoro- $\beta$-D-arabinofuranosyl) cytosine $\left(\left[{ }^{18} \mathrm{~F}\right]-\mathrm{FAC}, \mathbf{2 3}\right)$ as a PET tracer possessing a substrate affinity for both dCK and CDA 
comparable to gemcitabine (Figure 10). ${ }^{81,82}$ The deoxycytidine analogue bears one fluorine atom at the $\mathrm{C} 2$ ' position, instead of the two fluorine atoms in gemcitabine. The compound was synthesized with the goal of using it as a noninvasive method of DCK activity detection, which is helpful for personalized cancer therapy as a predictor of tumor response. The $\left[{ }^{18} \mathrm{~F}\right]-F A C$ was tested in both tumor cell lines as well as in mice with dCK-positive and dCK-negative tumor, with selectivity for dCK-positive tumors, comparable to gemcitabine. Because of its selectivity, the incorporation of ${ }^{18} \mathrm{~F}$ proves to be useful for the diagnosis of cancer. Extensive studies of $\left[{ }^{18} \mathrm{~F}\right]$-FAC have also been done in humans. ${ }^{83}$ Because it possesses similar characteristics as gemcitabine, $\left[{ }^{18} \mathrm{~F}\right]-\mathrm{FAC}$, also has the same critical disadvantages. It is a hydrophilic nucleoside analogue that can undergo inactivation by CDA. Because of these characteristics, its role as a radiotracer has its limitations. The Ritter group has also been involved in the first production of human doses of $\left[{ }^{18} \mathrm{~F}\right] 5$ fluorouracil, 24, a PET tracer for cancer imaging in humans, from $\left[{ }^{18} \mathrm{~F}\right]$ fluoride through the use nickel(II) $\sigma$-aryl complexes by transmetalation from arylboronic acids (Scheme 3). ${ }^{84}$
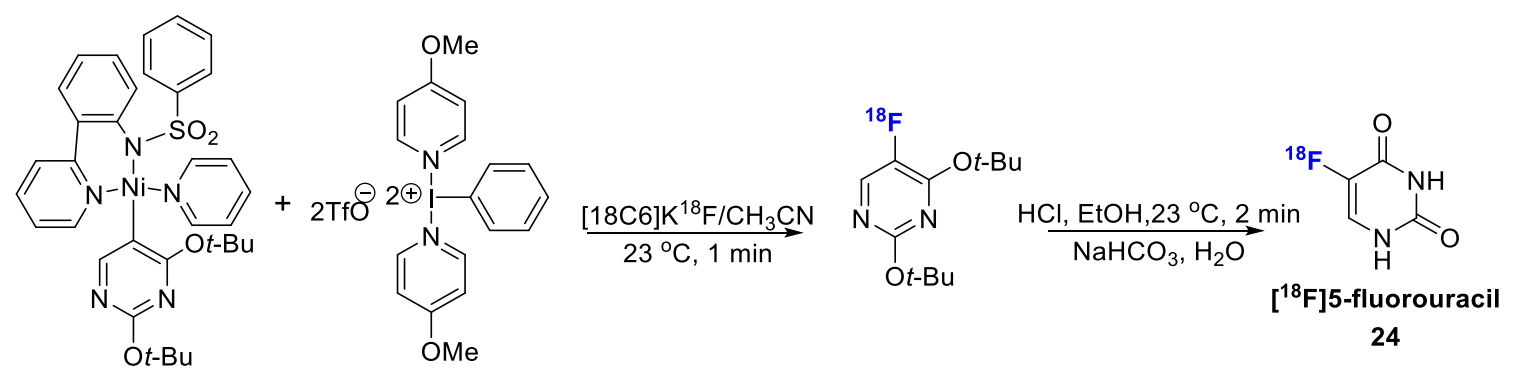

Scheme 3. Synthesis of $\left[{ }^{18} \mathrm{~F}\right] 5$-fluorouracil as a PET $\operatorname{tracer}^{84}$

The path for ${ }^{18} \mathrm{~F}$ radiolabeling has many obstacles, which include lengthy number of steps and burdensome labeling procedures. These obstacles are definitely the case for the synthesis of modified nucleosides analogues. Modification of nucleosides usually involve protection and deprotection steps. These steps, even with high conversion rates, can lead 
to an overall decrease of yield. Furthermore, the synthesis of compounds bearing carbonfluoride bond for PET imaging via substitution reactions can become troublesome with reaction conditions requiring relatively high temperatures and additives. Because of these issues, there is always the need to make this process more simple and efficient.

\subsubsection{Silicon ${ }^{18} \mathrm{~F}$ radiochemistry}

The use of Si-F bond formation in radiochemistry has been explored since $1958,{ }^{85}$ with in vivo studies reported as early as the 1970s and 1980s ${ }^{86}$ The use of Si-F for labeling came from comparing C-F and Si-F bond formation, as the bond energy of Si-F bond is about $90 \mathrm{~kJ} / \mathrm{mol}$ higher than the C-F bond. The C-F bond is generally metabolically stable, but to be formed, through electrophilic or nucleophilic reaction, the reactions tend to be harsh at bery high temperatures. Early on, it was discovered that even with this increase of bond energy, the Si-F bond is highly susceptible to hydrolysis in physiological conditions. ${ }^{87}$ The hydrolytic stability of this bond is highly depended on the substituents attached to silicon (Scheme 4) ${ }^{88}$ Schirrmacher et al., provided an alternative to the conventional 18-F radiopharmaceuticals that goes through the carbon-fluoride bond, prepared and tested triphenyl Si-F, diphenyl, $t$-butyl Si-F, and phenyl di-t-butyl-F compounds. It was noticed that having two bulky substituents in addition to one phenyl group provided the best stability for in vivo studies in human serum at $37.4{ }^{\circ} \mathrm{C}$ and $\mathrm{pH}$ 7.4-7.6. ${ }^{89}$ Ametamey et al. did an extensive experimental and theoretical hydrolysis study on a number of model organofluorosilanes, and they also showed that the tendency to hydrolysis can be prevented by the use of bulky substituents on the Si-atom (Figure 11). These compounds were dissolved in acetonitrile/aqueous buffer at $\mathrm{pH} 7$ and incubated at ambient temperature. Several compounds were tested and they concluded that isopropyl (28-30) and $t$-butyl (31) 
groups were significantly more stable than methyl groups when attached to Silicon. ${ }^{90,91}$ With these extensive stability studies, it was concluded that these type of compounds, now labeled for fluoride acceptors (SiFA), are a reliable alternative for ${ }^{18} \mathrm{~F}$ PET imaging protocols.

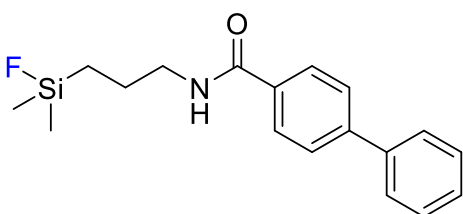

25

$<<5$ min

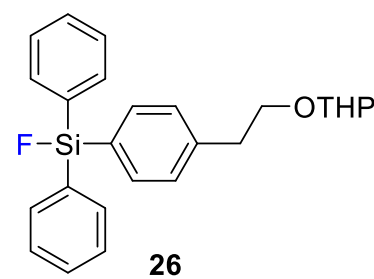

$6 \min$

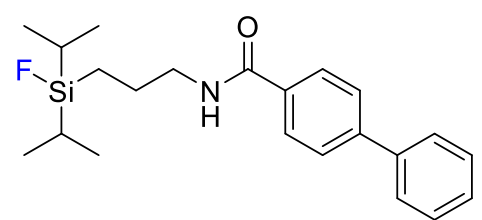

27

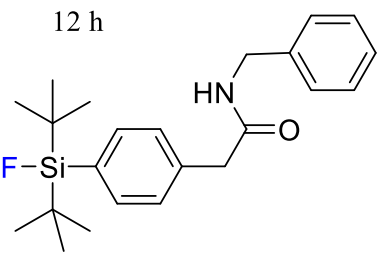

31

$>300 \mathrm{~h}$

Figure 11. Hydrolysis half-lives $\left(\mathrm{t}_{1 / 2}\right)$ of selected organofluorosilanes under aqueous buffer ( $\mathrm{pH} 7)$ and ambient temperature reported by Höhne et al. ${ }^{91}$

The Si-F hydrolysis is also affected by the leaving groups attached to the silicon atom. Early on it was noticed that the use of chloro as the leaving group was not optimal because of their strong tendency to form silanol derivatives ( $\mathrm{Si}-\mathrm{OH})$, meaning it undergoes hydrolysis easily. The high tendency for hydrolysis meant that other options needed to be explored. Klar and Ametamey were able to fluorinate silane peptides with $\mathrm{H}$ and $\mathrm{OH}$ as leaving groups. These compounds, which also bear bulky groups, were fluorinated with no issue, but it was noticed that $\mathrm{OH}$ and alkoxyl moieties requires the presence of acid for better exchange. ${ }^{90}$ 


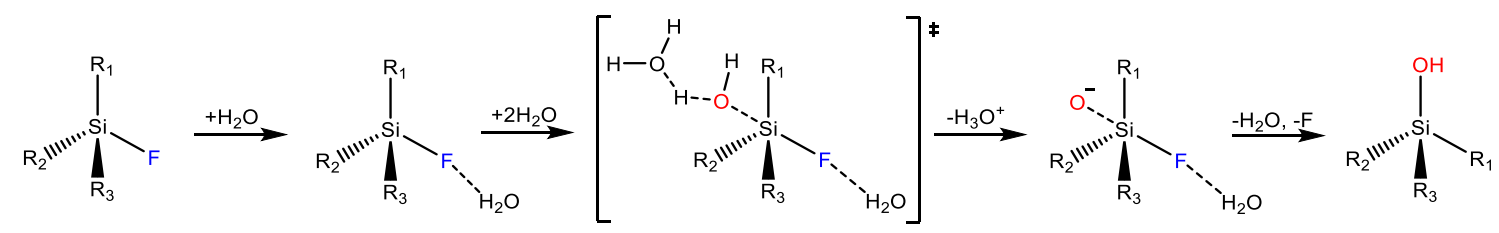

Scheme 4. Hydrolysis reaction of $\mathrm{Si}-\mathrm{F}$ bond to $\mathrm{Si}-\mathrm{OH}$

Isotopic exchange reactions have been a key aspect in the study of ${ }^{18} \mathrm{~F}$ radiochemistry (Scheme 5). In the case of carbon-fluorine reactions, the exchange is usually with low yields which leads to no in vivo applications. In addition, there is a problem with specific activity when ${ }^{19} \mathrm{~F}-\mathrm{C}$ bonds occupy receptors. In the case of Si-F, because these reactions are in higher yields, isotopic exchange can be an advantage. It has been shown that isotopic exchange reactions have occurred in high radiochemical yields with high specific activity. ${ }^{92}$ The labeling procedure also becomes more convenient because there is no need for purification as the labeling precursor and labeled compound are identical.

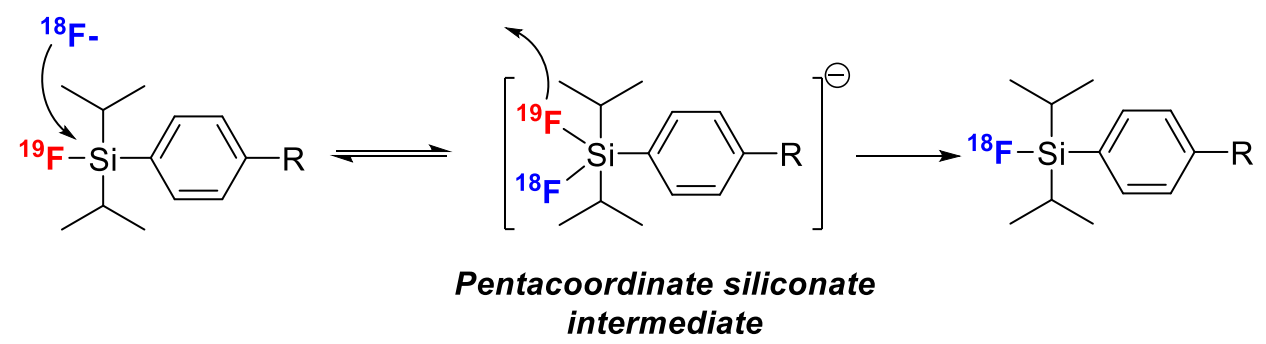

Scheme 5. Mechanism of isotopic exchange reaction between ${ }^{18} \mathrm{~F}$ and ${ }^{19} \mathrm{~F}$

These silicon-fluoride acceptor building blocks are hydrophobic, which means that if they introduced in the body for imaging, they would accumulate in the liver. To prevent liver accumulation, these building blocks are usually connected to peptides and other small molecules, ${ }^{90,92-95}$ which increase the overall hydrophilicity. In the case of peptides, the incorporation of silicon-fluoride acceptors involve multistep syntheses that involve the addition of linkers and auxiliaries that reduce lipophilicity. Additionally, because of the 
number of amino acid residues that might react, additional protection steps need to be used. Lovkova et al. synthesized a set of Octreotate analogues by modifying phenylalanine with a silicon-fluoride acceptors and introducing it through solid phase peptide synthesis (32, Figure 12). ${ }^{96}$ Silicon-fluoride acceptors have also been utilized in proteins for PET imaging. ${ }^{97,} 98$

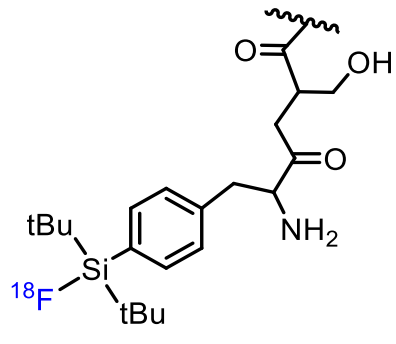

32

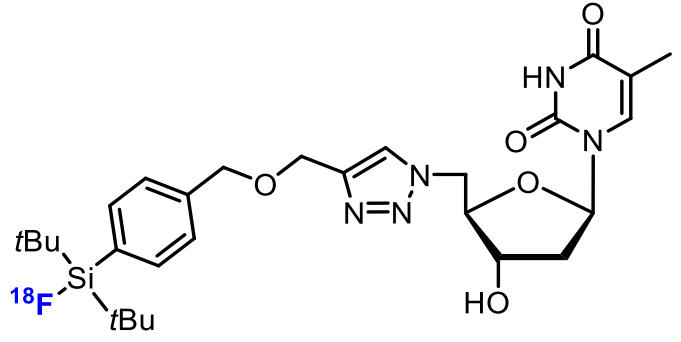

33

Figure 12. Silicon-fluoride acceptors in octreotate ${ }^{96} \mathbf{3 2}$ and thymidine derivatives ${ }^{99} \mathbf{3 3}$

When discussing silane derivatives for their use as a tracer, to my knowledge, not much work has been done with nucleosides or nucleoside analogues. Schulz et al. reported a protocol for the efficient radiolabeling of nucleosides and oligonucleotides derivatives containing the silicon-fluoride acceptors building block (Figure 12). ${ }^{95,99,100}$ Schulz's work involved the use of natural nucleosides modified at the $\mathrm{C}^{\prime}$ ' and $\mathrm{C}^{\prime}$ ' (33) position of the sugar. As of this moment, there is no published work on the integration of nucleoside-based drugs with silicon-fluoride acceptors for PET imaging. It would be very interesting to explore their use as anti-cancer and anti-viral nucleoside theranostic agents.

\subsection{Reduction of lactones to hemiacetals}

\subsubsection{Synthetic significance of reduction of lactones to hemiacetals}

The reduction of sugar lactones to hemiacetals plays an important role in the synthesis of modified carbohydrates and nucleosides. When discussing carbohydrates, we shall focus 
on the synthesis of modified monosaccharaides, more specifically pentoses and hexoses. Beaupere et al. worked on the synthesis of 5- and 6-alkyl sulfanyl derivatives. ${ }^{101-103}$ These types of thiosugar derivatives have shown to have therapeutic potential against several diseases, including cancer. ${ }^{103}$ These derivatives were made through the modifications of ribonolactones, (e.g., 34) which ultimately are reduced with $\mathrm{NaBH}_{4}$ to $S$-Alkylthiopentitol 36 (Scheme 6). Another example is the conversion of D-hexono-1,5-lactones (e.g., 37) into cyclic hemiacetals of L-hexoses 39 through a $\gamma$-hydroxyalkoxamate derivatives using DIBAL-H. ${ }^{102,104}$
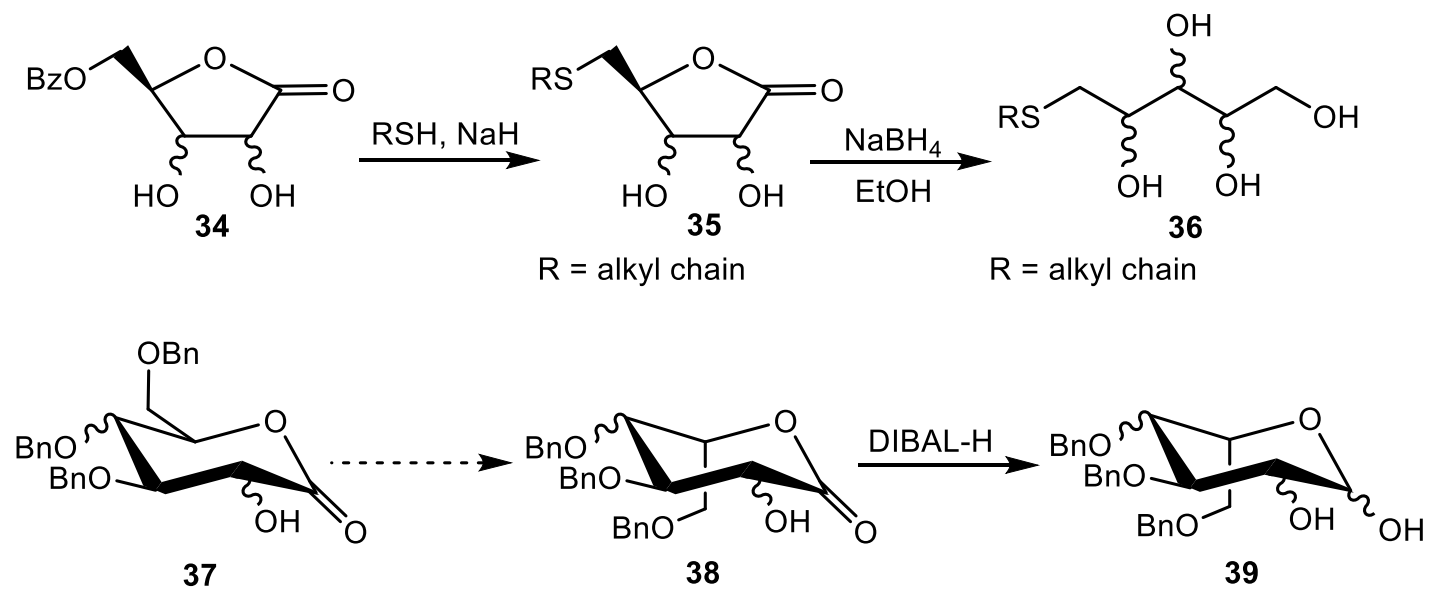

Scheme 6. Reduction of lactones with $\mathrm{NaBH}_{4}$ and DIBAL-H

Reduction of pre-constructed sugar lactones to their corresponding lactols and their further coupling with nucleobases are often key steps in the synthesis of important nucleoside-based drugs such as the anticancer gemcitabine, anti-HIV 3TC and dideoxynucleosides among others. ${ }^{3,105,106}$ In the case of gemcitabine, 1, there have been many routes attempted and explored but the majority of them involve the use of a modified sugar lactone for synthesis of difluororibose of carbohydrate derivatives. ${ }^{3}$ Chou et al. 
synthesized difluororibose derivative $\mathbf{4 1}$ through a lactone derivative to then couple with cytosine to synthesize gemcitabine (Scheme 7). ${ }^{107}$

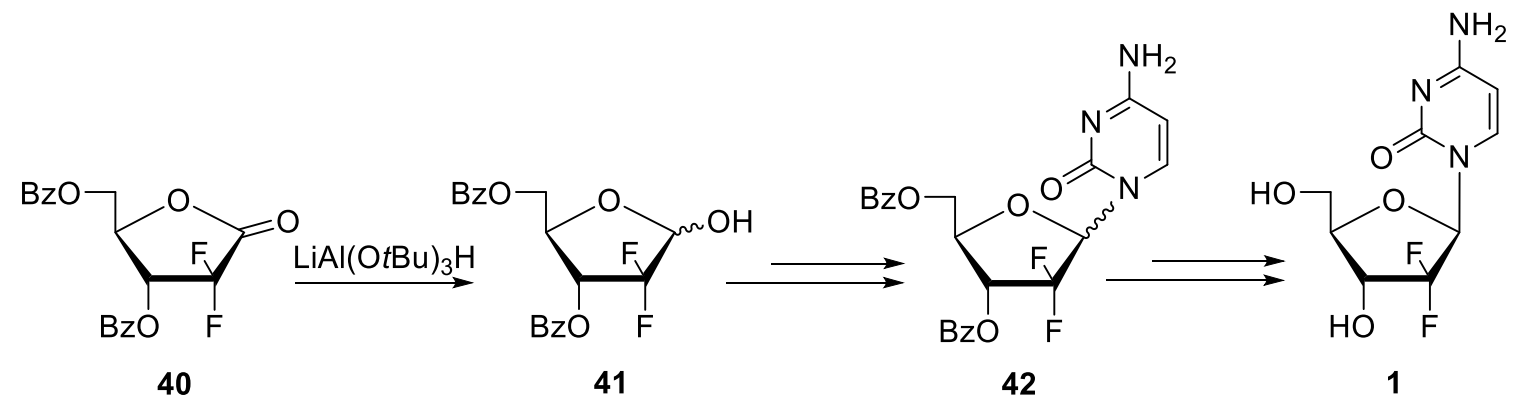

Scheme 7. Synthesis of gemcitabine through reduction of sugar lactones

Choi et al. synthesized dioxolanyl 45 and oxathiolanyl 48 nucleoside analogues also by using sugar lactones which were then coupled to their respective bases. In the synthesis of dioxolanyl, Choi, utilized $\mathrm{LiAl}(\mathrm{O} t \mathrm{Bu})_{3} \mathrm{H}$ to reduce the lactone, while DIBAL-H for the synthesis of oxathiolanyl (Scheme 8$).{ }^{108}$

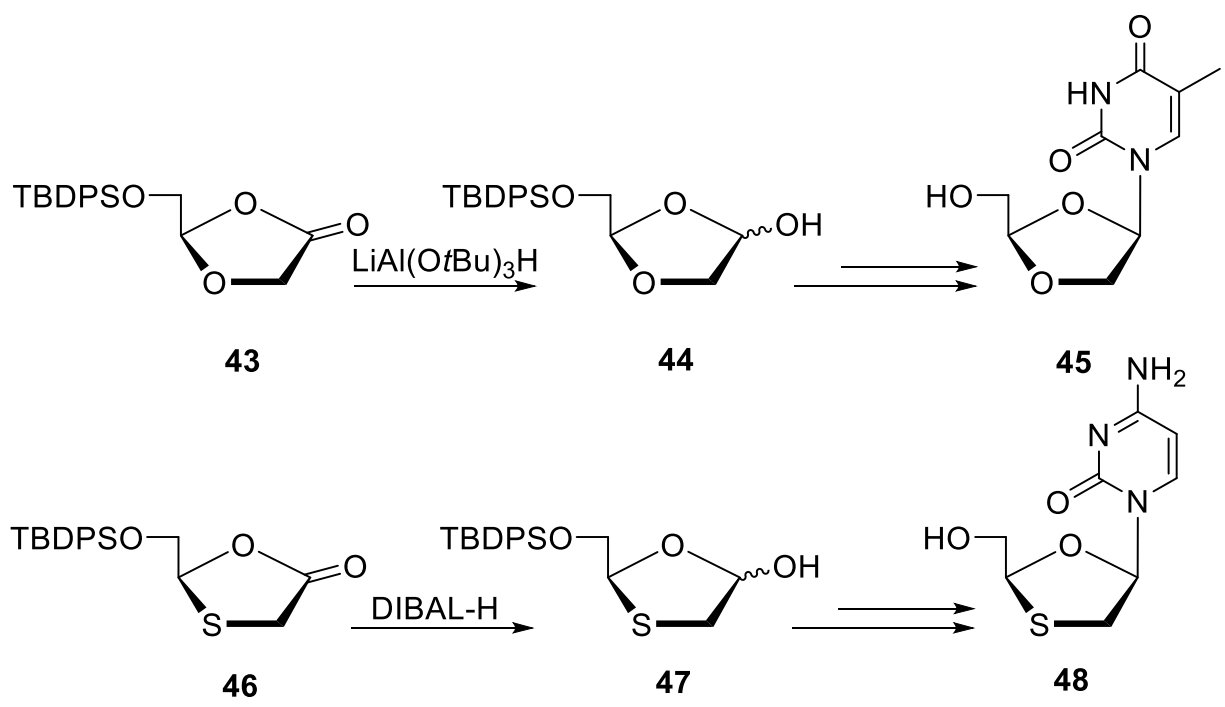

Scheme 8. Synthesis of oxathiolanyl and dioxolanyl nucleoside analogues through reduction of sugar lactones ${ }^{108}$

On the development of novel inhibitors of $S$-ribosylhomocysteine (SRH) hydrolase (LuxS; EC 4.4.1.21), the Wnuk group has had the challenge of reducing modified sugar 
lactones to their corresponding hemiacetals. Lithium triethylborohydride (LTBH, SuperHydride $\left.{ }^{\circledR}\right)^{109}$ has been utilized for the reduction of lactam (Scheme 10) and lactone analogues of SRH to the corresponding azahemiacetals $(N, O \text {-acetals })^{110,111}$ or lactols $(O, O$ acetals $)^{112}$, a method not extensively explored. Below, the commonly used reducing agents for this type of transformation will be reviewed.

\subsubsection{Reducing agents for reduction of lactones to hemiacetals}

The commonly used reagents for the reduction of lactones to hemiacetals include $\mathrm{NaBH}_{4}$, and a variety of organic-soluble metal hydrides such as DIBAL-H and other boranes. ${ }^{113-115}$ Additionally, $\mathrm{LiAlH}_{4}$, under controlled reaction conditions, has also been used for this purpose. $\mathrm{NaBH}_{4}$ has been shown to be effective in the reduction of sugar lactones to aldoses. However, it requires aqueous acid conditions to prevent over reduction, which is problematic for nonpolar and/or acid labile protected compounds that are commonly used in nucleoside and carbohydrate chemistry. ${ }^{116-118}$

Diisobutyl aluminum hydride, DIBAL-H, an intensively studied organometallic reducing agent, reduces esters (including lactones) as well as nitriles to aldehydes. ${ }^{119,} 120$ Diisobutyl aluminum hydride has been shown to be an efficient reagent for many of the reactions discussed above, but it usually requires low temperatures $\left(-78^{\circ} \mathrm{C}\right)$ and large excess of the reagent, which is a disadvantage for large-scale work. ${ }^{105}$ In addition, extra precautions need to be taken when manipulating DIBAL-H because it is air-sensitive and pyrophoric in nature. Alternatives reagents for this transformation have been proposed. Buchwald et al. demonstrated the catalytic reduction of lactones to hemiacetals with generated in situ titanocene(III) hydride, in the presence of silanes as a hydride source (Figure 13). ${ }^{121,} 122$ Their initial findings involved the use of $n$-BuLi as a catalyst activator 
and phenylsilane. Even though they obtained their lactol products with a minimal amount of diol, phenylsilane was expensive and $n$-BuLi reacts violently with water. They later optimized their method by implementing the use of polymethylhydrosiloxane (PMHS) as an activator. Their method was utilized for the large scale preparation of several sugar hemiacetals.

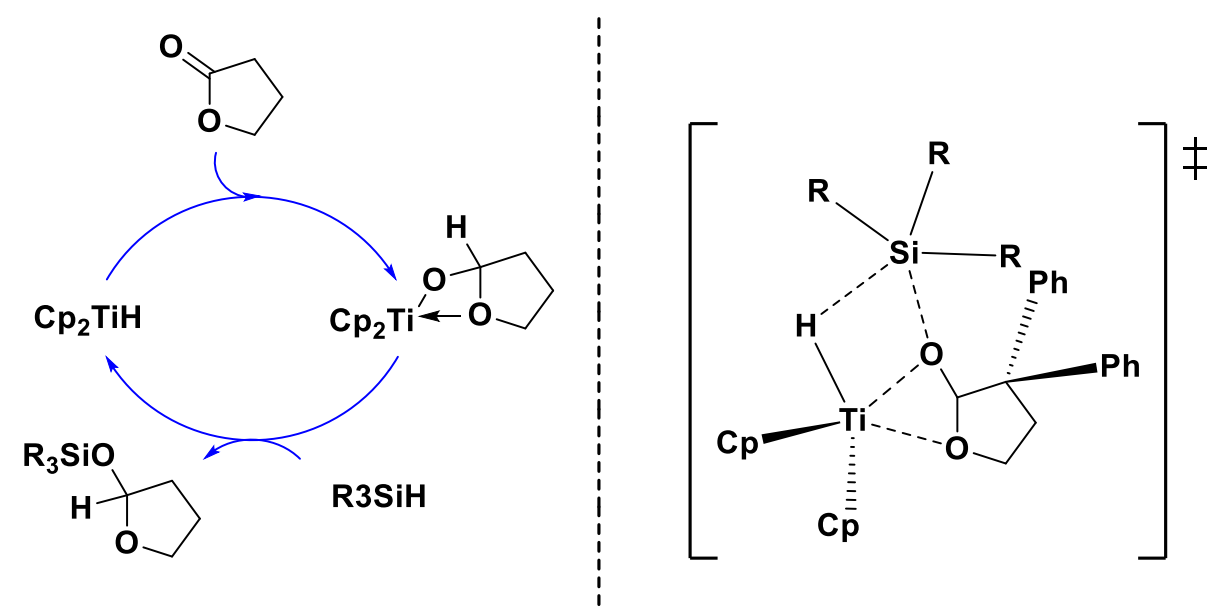

Figure 13. Catalytic cycle and transition state proposed by Buchwald et al. ${ }^{121}$

Limitations to this method include the size of the lactone ring, with larger rings producing the open aldehyde product that is then reduced to diols and in compounds bearing both a lactone as well as an ester group, when subjected to the hydrosilylation conditions, the ester moiety was reduced to the alcohol while the lactone moiety was reduced to the lactol (Scheme 9). ${ }^{121,122}$ 

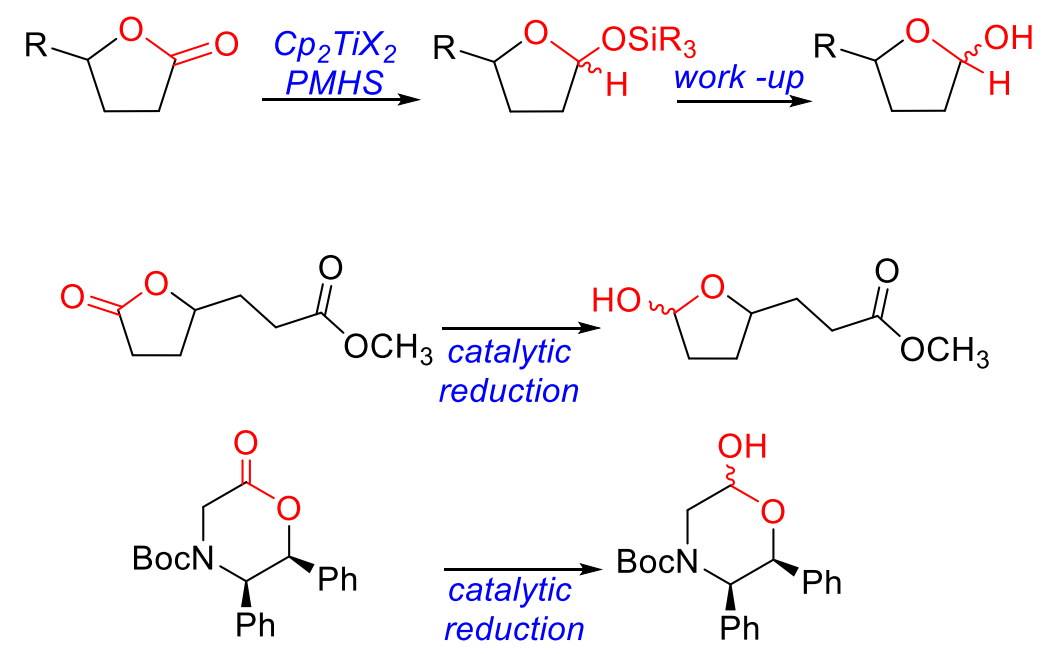

Scheme 9. General and specific reduction of lactones with titanocene(III) hydride ${ }^{122}$

Although borane-based reagents have been used for the reduction of lactones to lactols and diols, ${ }^{114}$ reports of reductions of sugar lactones to lactols using borane reagents are sparse. For example, disiamylborane was used for the conversion of 2,3-di-O-acetyl-5-Sacetyl-5-thio-D-arabinono-1,4-lactone 49 to the corresponding arabinofuranose $\mathbf{5 0},{ }^{102}$ and Selectride was employed for the partial reduction of acetyl protected D-galactono-1,4lactone 51 (Scheme 10). ${ }^{123}$

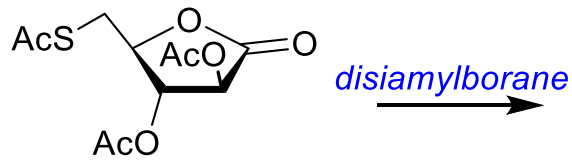

49

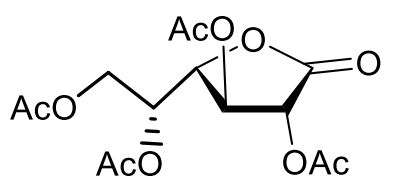

51

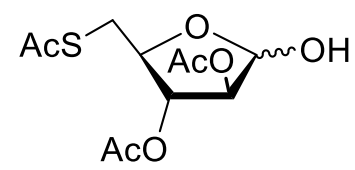

50

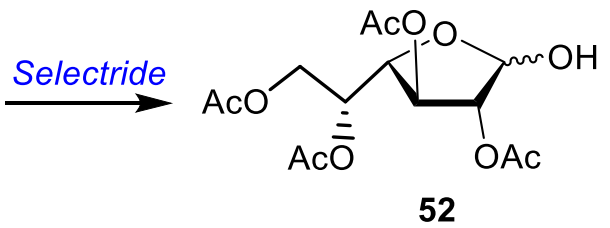

Scheme 10. Use of borane-based reducing agents for reduction of lactones to hemiacetals

Also, application of LTBH for the reduction of lactams to cyclic hemiaminals (azahemiacetals) has been used by Casiraghi, Schofield et al. in the synthesis of 
dihydroxyprolines 55 and functionalized prolines respectively 54 (Scheme 11). ${ }^{124,125}$ To the best of my knowledge, there is no other examples in sugar lactones being reduced to hemiacetals with the use of LTBH.
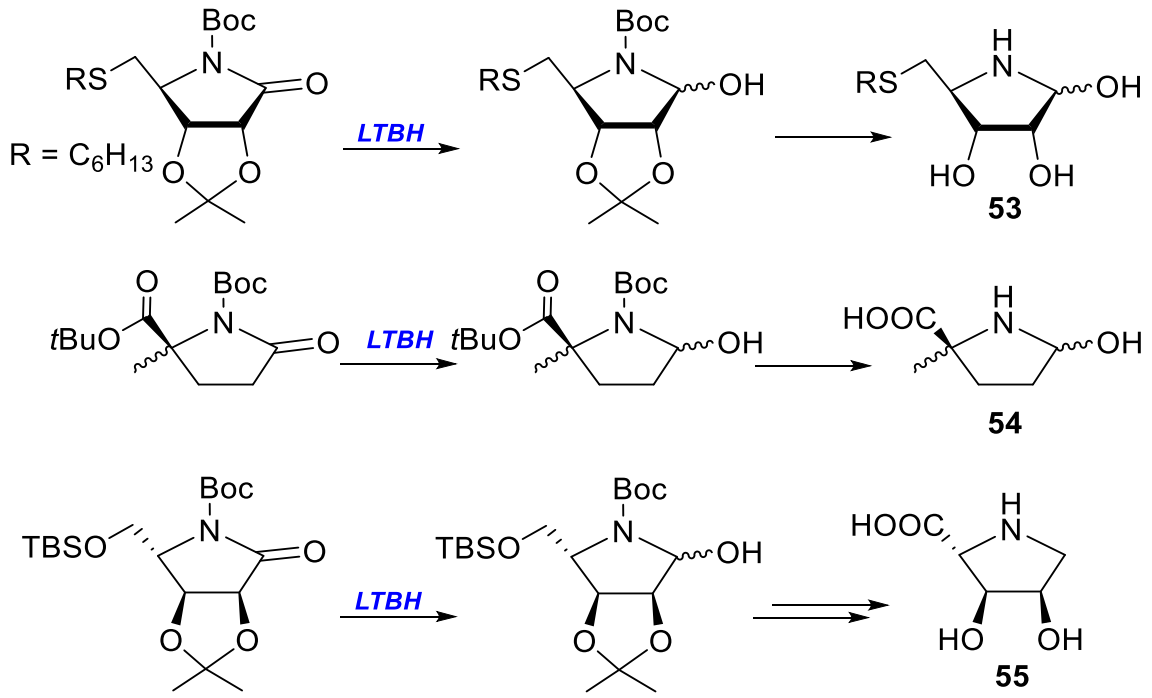

Scheme 11. Synthesis of cyclic azahemiacetals SRH analogues $\mathbf{5 3}^{111}$, dihydroxyprolines $\mathbf{5 4}$ and functionalized prolines $\mathbf{5 5}$ through the use of $\mathrm{LTBH}^{124,125}$ 


\section{RESEARCH OBJECTIVES}

The main objective of my dissertation is the synthesis and in vivo and in vitro biological evaluation of novel 4- $N$-alkyl gemcitabine analogues with i) $\beta$ keto sulfonate moieties (A) and ii) 4- $\mathrm{N}$-alkanoyl and 4- $\mathrm{N}$-alkyl gemcitabine analogues bearing silicon-fluoride acceptor building blocks (B \& C) suitable for ${ }^{18} \mathrm{~F}$ labeling (Figure 14).

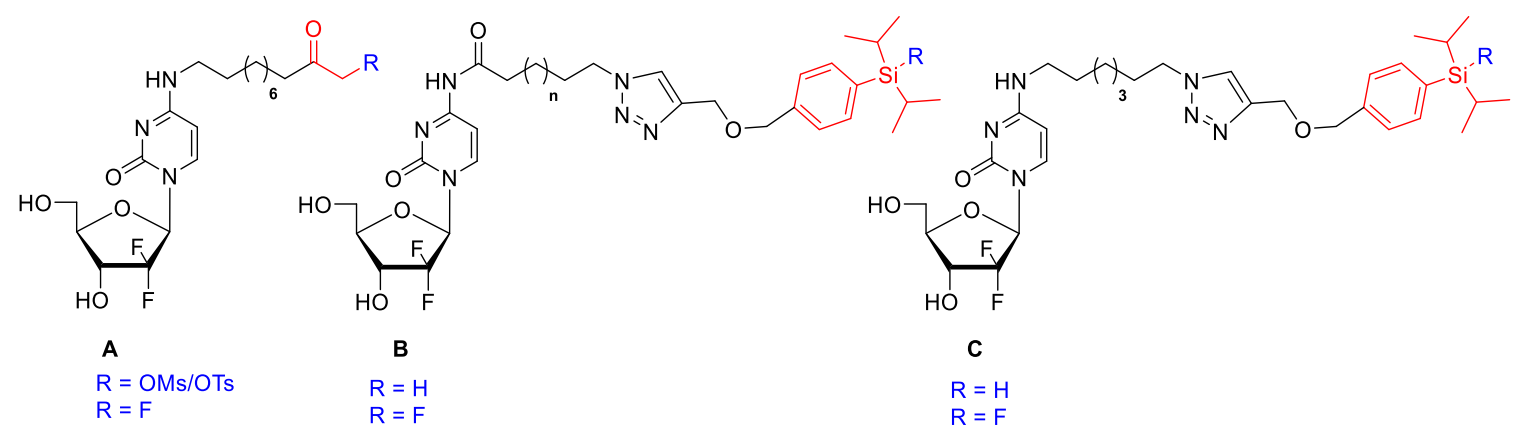

Figure 14. Proposed structures of $4-N$-alkanoyl and $4-N$-alkyl gemcitabine analogues

The design and synthesis of 4- $\mathrm{N}$-alkanoyl gemcitabine analogues, through a number of strategies, have shown to decrease the release of the parent drug, increasing its bioavailability and used in theranostics. In the case of 4- $\mathrm{N}$-alkyl gemcitabine analogues, the Wnuk's group has shown that these type of analogues have increased stability as they are enzymatically resistant to cleavage and intracellular deamination by CDA at $4-\mathrm{N}$ position. Their stability provides an alternative strategy for PET imaging.

The synthesis of the $4-N$-alkyl gemcitabine analogues with $\beta$ keto sulfonate moieties $\mathbf{A}$ involves 4- $N$-alkylation of gemcitabine followed by a series of oxidation steps in the side chain of the gemcitabine analogue to provide the $\beta$ keto sulfonate. The latter are anticipated to be good substrates for an efficient fluorination, including fluorination protocols with ${ }^{18} \mathrm{~F}$ labeling. Moreover, the $\beta$ keto moiety is expected to prevent chemical elimination of HF of fluoride anion during cell assays because of its lack of $\beta$-hydrogens. In my second 
approach for the synthesis of gemcitabine-derived PET imaging precursors I was planning to investigate the use of silicon-fluoride acceptors for an alternative mode of fluorination. The synthesis of such gemcitabine analogues with silicon-fluoride acceptors would involve the preparation of 4- $\mathrm{N}$-alkyl or 4- $\mathrm{N}$-alkanoyl derivatives of gemcitabine with a terminal azido or terminal alkyne group for efficient click chemistry with silane counterparts.

These analogues are expected to have greater bioavailability than gemcitabine by providing an increase in lipophilicity and in the case of the 4- $\mathrm{N}$-alkyl analogues, increased chemical and fluoride stability. Therefore, the next objective was to study the cytotoxicity of these 4- $\mathrm{N}$-gemcitabine as well as study their capability as radioligands for positron emission tomography imaging with ${ }^{18} \mathrm{~F}$.

The synthesis of modified nucleosides and sugars, including SRH analogues, often require the reduction of sugar lactones to the corresponding hemiacetals in the final steps of their synthetic pathways. Therefore, in my last objective, I envisioned optimizing conditions for the partial reduction of lactones to hemiacetals. The goal of the objective was to study reduction conditions of different protected and unprotected sugar lactone derivatives with common organic-based reducing reagents, with a special focus on lithium triethylborohydride (LTBH), that are usually used in carbohydrate chemistry for their conversion to lactols and/or hemiacetals (Scheme 12).

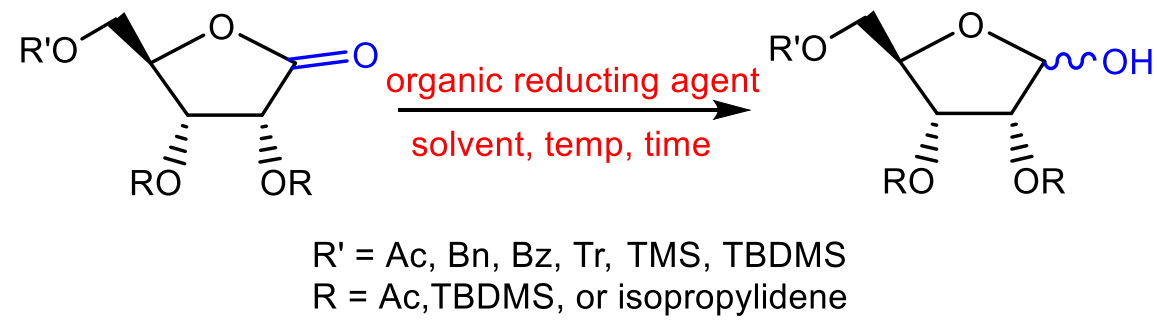

Scheme 12. Reduction of sugar lactones to hemiacetals under various conditions 


\section{RESULTS AND DISCUSSION}

\subsection{Design and synthesis of 4-N-alkanoyl and 4- $N$-alkyl gemcitabine analogues}

\subsubsection{4- $N$-Alkyl $\beta$-keto sulfonate gemcitabine analogue}

\subsubsection{4- $N$-Alkyl $\beta$-keto sulfonate gemcitabine analogue: Rationale}

The goal of my objective was the synthesis of 4- $\mathrm{N}$-modified gemcitabine analogue with a $\beta$-hydroxyl keto moiety suitable for ${ }^{18} \mathrm{~F}$ radiolabeling $(\mathbf{A})$. The addition of an aliphatic chain should affect cellular uptake of the drug by its increased lipophilicity, while the 4- $\mathrm{N}$ alkyl modification, bearing $\beta$-hydroxy-keto moiety, with the ability of conversion of hydroxyl group to a leaving group, provides opportunity for the incorporation of the fluorine atom suitable for ${ }^{18} \mathrm{~F}$ PET imaging. The modification at $4-\mathrm{N}$-alkyl of nucleosides containing cytosine such as gemcitabine has been reported by our group to have less cytotoxic strength as compared to their $4-\mathrm{N}$-alkanoyl counterparts. ${ }^{28}$ This cytotoxicity is hypothesized to be a result of their lack of hydrolysis back to the parent molecule, gemcitabine. There is minimal phosphorylation and DNA incorporation, but it also means that there is an increased stability, with the compound entering and staying in the cell. The increased stability is a positive effect for its role in ${ }^{18} \mathrm{~F}$ PET imaging of cancerous tumors. The stability of the 18-fluorine labeled gemcitabine in biological conditions is an issue observed-previously by Pulido et al. They showed that their 4- $N$-fluoroalkylgemcitabine $\left[{ }^{18} \mathrm{~F}\right]$-radioligand (10) underwent in vivo defluorination when introduced to non-tumor bearing and tumor bearing mice. The defluorination was apparent by the accumulation of ${ }^{18} \mathrm{~F}$ - signal in the bones over time ${ }^{38}$ and was most likely the result of elimination reactions that can occur with $\beta$-hydrogens to the fluorine available in the side chain. The presence of a $\beta$-carbon that lacks hydrogens can evade this issue. With that in mind, a $\beta$-hydroxyketo 
gemcitabine analogue, which lacks $\beta$ hydrogens can provide the necessary stability for the fluorine labelled probes (Figure 15).
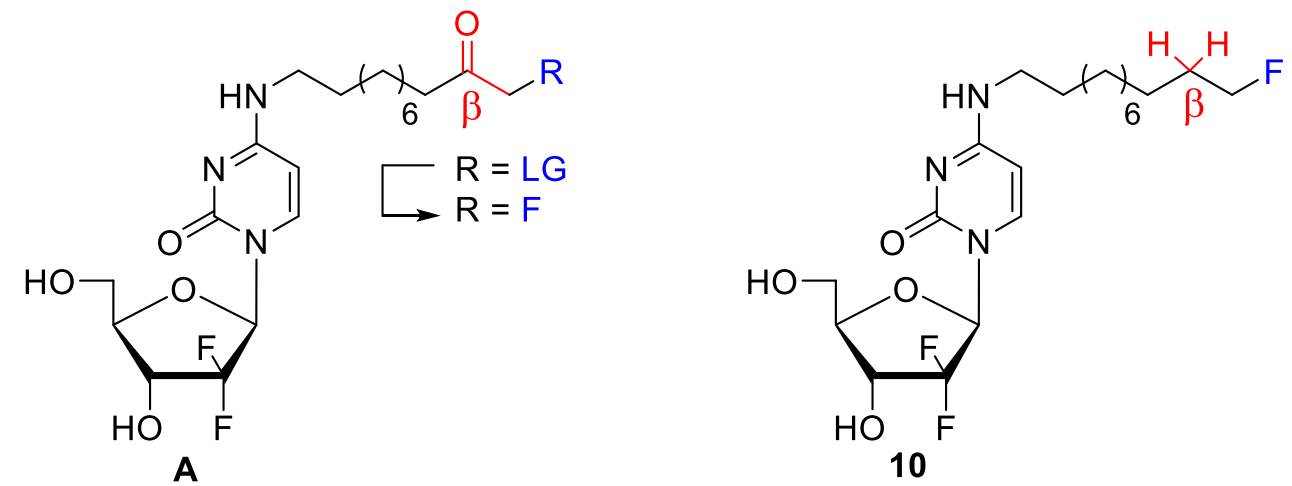

Figure 15. Key structural differences between $\beta$-keto $\mathbf{A}$ and $4-N$-alkyl 10 gemcitabine analogues

\subsubsection{4- $N$-Alkyl $\beta$-keto sulfonate gemcitabine analogue: Synthesis}

The synthesis of 4- $N$-alkylgemcitabine with $\beta$-keto substituent was attempted through two different pathways. The first pathway was through the synthesis of the desired alkyl amine modified sidechain bearing a terminal $\alpha$-hydroxy methyl ketone, followed by its coupling with 4-N-tosylgemcitabine 62. The second pathway involves coupling of the commercially available 1-amino-10-undecene with $4-N$-Ts-gemcitabine $\mathbf{6 2}$, with the chemical modifications of the sidechain done post coupling. It is important to state that in both cases, the fluorination is carried out in last step so the product can be conveniently used for PET imaging in the medical setting.

For the first pathway, treatment of 1-amino-10-undecene 56, with di-t-butyl dicarbonate $\left(\mathrm{Boc}_{2} \mathrm{O}\right)$ provided Boc-protected amine 57 (95\%). Oxidation of terminal olefin of Boc-protected amine $\mathbf{5 7}$ was effected with a catalytic amount of osmium tetraoxide $\left(\mathrm{OsO}_{4}\right)$ and $N$-methylmorpholine- $N$-Oxide (NMO) to yield vicinal diol 58 (88\%). Regioselective benzylation of amino diol $\mathbf{5 8}$ with $\mathrm{BnBr}$ effected protection of the primary 
hydroxide, yielding amino alcohol 59. The average yield in this reaction was $51 \%$, because of benzylation of both hydroxide groups. Oxidation of benzyl protected amino alcohol $\mathbf{5 9}$ with Collins reagent yielded amino keto $\mathbf{6 0}(91 \%)$. This was followed by deprotection of Boc group by treatment with TFA yielding amino keto 61 (93\%, Scheme 13).

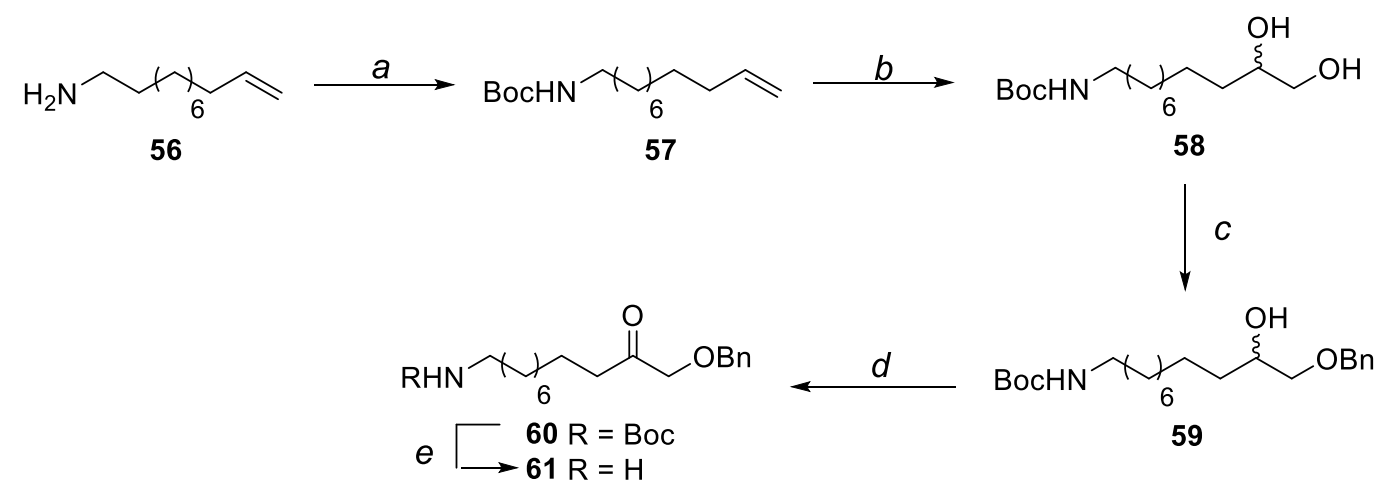

${ }^{a}$ Reactions and conditions:(a) $\mathrm{Boc}_{2} \mathrm{O} / \mathrm{MeOH}$; (b) (i) $\mathrm{OsO}_{4} / \mathrm{NMO}$ (1.5 eq.)/acetone: $\mathrm{H}_{2} \mathrm{O}$ (10:1); (c) $\mathrm{BnBr}$ (1 eq.) $/ \mathrm{Ag}_{2} \mathrm{O}$ (1 eq.) $/ \mathrm{CH}_{2} \mathrm{Cl}_{2}$; (d) Collins Reag/ $\mathrm{CH}_{2} \mathrm{Cl}_{2} ;$ (e) TFA/ $\mathrm{CH}_{2} \mathrm{Cl}_{2}$.

Scheme 13. Synthesis of amino with $\beta$-keto side chain

With the side chain modified, the next step was the coupling with gemcitabine. Thus, reaction of transient protected with trimethylsilyl group gemcitabine with $\mathrm{TsCl}$ in the presence of pyridine followed by deprotection with methanolic ammonia afforded 4-Ntosylgemcitabine $\mathbf{6 2}(90 \%) .{ }^{28}$ Tosylate $\mathbf{6 2}$ was then treated with Et $3 \mathrm{~N}$ (TEA)/1,4-dioxane and amino side chain 61 for the expected $\beta$-keto-4-N-alkylgemcitabine 63. The coupling reaction was attempted three times with varying temperature (from $35^{\circ} \mathrm{C}$ to $75^{\circ} \mathrm{C}$ ) with no desired coupled product observed (Scheme 14) with tosylated gemcitabine and modified side chain recovered in all case. Additionally, the purity of the amine appears to be key for a successful transamination reaction. 


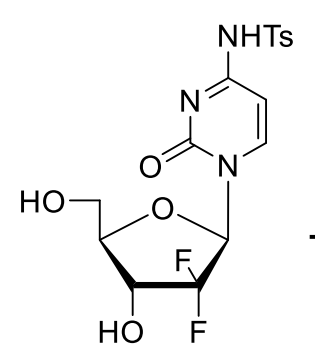

62

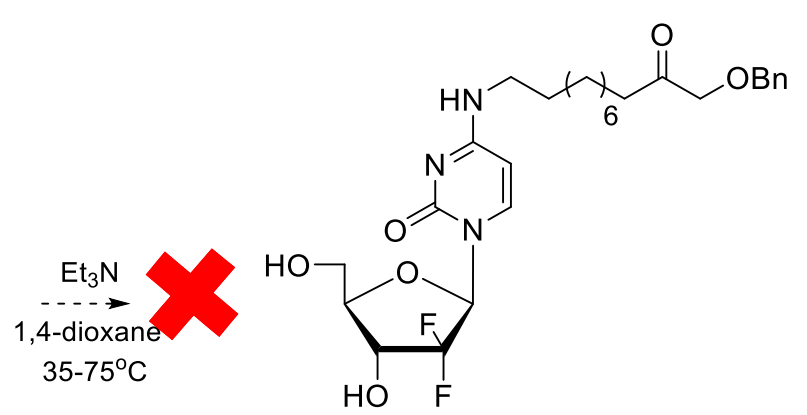

63

Scheme 14. Unsuccessful attempted 4- $N$-tosylgemcitabine 62 and 61 coupling reaction

To check the validity of my approach, I took advantage that amino diol $\mathbf{5 8}$ was synthesized in great quantity. The modification of the side chain provided an opportunity to test fluorination reactions. Thus, vicinal diol $\mathbf{5 8}$ was regioselectively mesylated with 1.1 eq. $\mathrm{MsCl}$ at low temperature at the terminal primary hydroxyl to give mono-mesylate 64 (55\%). Subsequently, oxidation of 64 with DMP gave $\beta$-keto mesylate 65 (92\%). Appearance of $\alpha$-hydrogens to the newly formed keto at 2.5 and $4.8 \mathrm{ppm}$ on ${ }^{1} \mathrm{H} \mathrm{NMR}$ and peak at 205 ppm on ${ }^{13} \mathrm{C}$ NMR demonstrated oxidation of secondary alcohol to ketone. Next, fluorination was explored by displacement of mesylate with fluoride. Initially, fluorination was attempted using conventional radiosynthetic protocol. Treatment of $\mathbf{6 5}$ with $\mathrm{KF}$ in the presence of $\mathrm{K}_{2} \mathrm{CO}_{3}$ and Kryptofix 222, carried out in $\mathrm{CH}_{3} \mathrm{CN}$ at $80^{\circ} \mathrm{C}$ for 25 min gave $66(55 \%)$. Interestingly, better yields of 66 were obtained when 65 was treated with TBAF as fluorinating agent $(80 \%$, Scheme 15$)$. In both cases, ${ }^{19} \mathrm{~F}$ NMR showed formation of the expected triplet at $-227.5 \mathrm{ppm}$. 

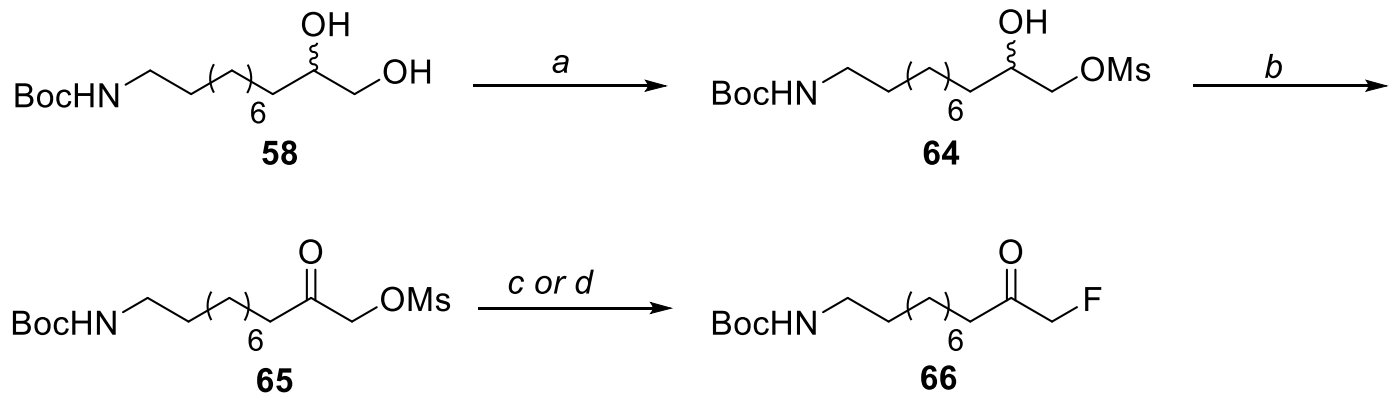

${ }^{a}$ Reagents and Conditions: (a) $\mathrm{MsCl}$ (1.1 eq.) $/ \mathrm{Et}_{3} \mathrm{~N} / \mathrm{CH}_{2} \mathrm{Cl}_{2} /-20^{\circ} \mathrm{C}$;

(b) $\mathrm{DMP} / \mathrm{CH}_{2} \mathrm{Cl}_{2}$; (c) $\mathrm{KF} / \mathrm{Kryptofix} 2.2 .2 / \mathrm{CH}_{3} \mathrm{CN} / 80^{\circ} \mathrm{C} / 25 \mathrm{~min}$; (d) $\mathrm{TBAF} / \mathrm{THF} / 60^{\circ} \mathrm{C}$.

Scheme 15. Synthesis of fluoro $\beta$-keto side chain

The fluorination of the side chain provided the foundation for the continuation of the project by using the second approach. The synthesis of the targeted gemcitabine analogue was accomplished through three main critical transformations: (i) displacement of 4- $\mathrm{N}$ tosylamine group with commercially available 1-amino-10-undecene, (ii) modification of terminal olefin to $\beta$-keto sulfonate moiety, and (iii) displacement of sulfonate leaving group with fluoride followed by deprotection (Scheme 16).

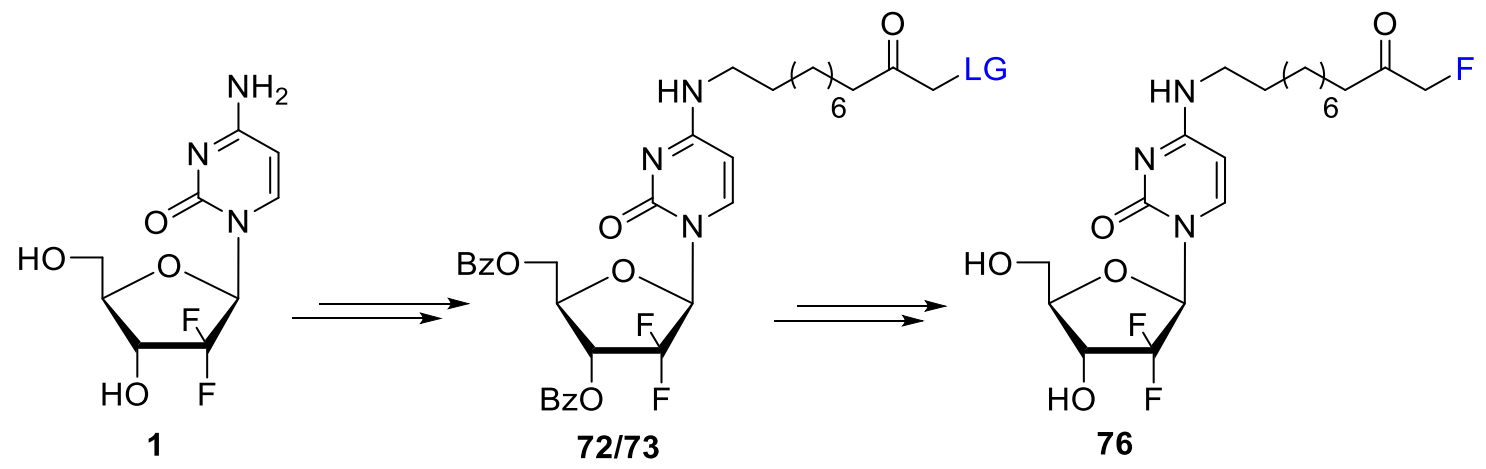

Scheme 16. Overall synthesis of $4-N$-modified $\beta$-keto fluoro gemcitabine analogue

The alkylation of the 4-exocyclic amine group in gemcitabine was achieved by displacement of a 4-N-tosylamine group with 1-amino-10-undecene. Treatment of $\mathbf{6 2}$ with 1-amino-10-undecene effected displacement of the $p$-toluenesulfonamido group from the 
$\mathrm{C} 4$ position of the cytosine ring to give $4-N-(10$-undecene) derivative $\mathbf{6 7}(85 \%$, scheme $17)$.
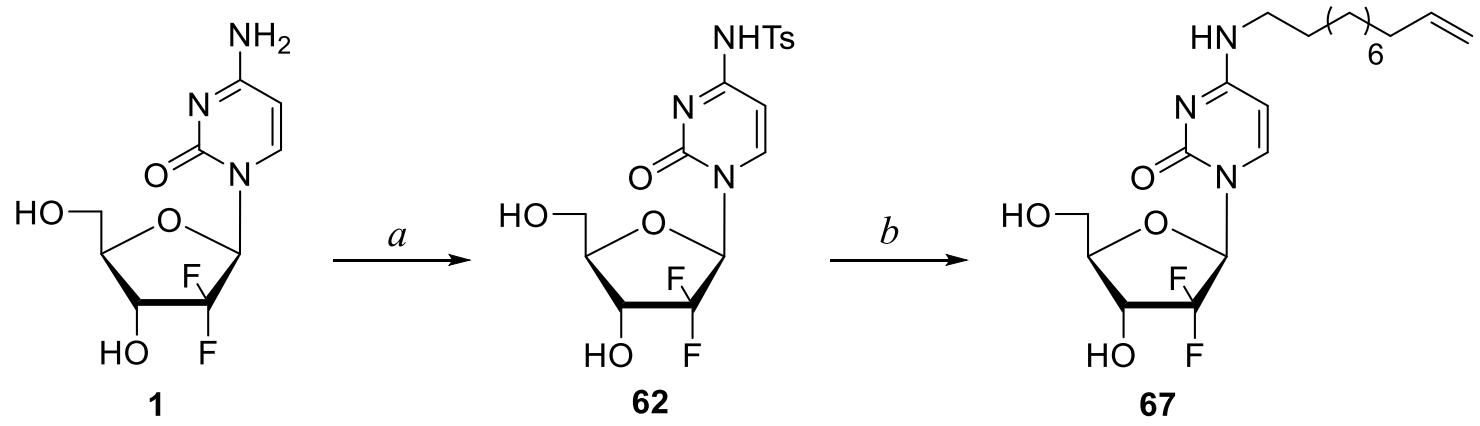

${ }^{a}$ Reagents and Conditions:(a) (i) $\mathrm{TMSCl} / \mathrm{Pyr}$, (ii) $\mathrm{TsCl}$, (iii) $\mathrm{MeOH} / \mathrm{NH}_{3}$;

(b) 1-amino-10-undecene/ $\mathrm{Et}_{3} \mathrm{~N} / 1,4$-dioxane

Scheme 17. Synthesis of 4- $N$-(10-undecene) gemcitabine analogue

Benzoylation of $4-N$-alkene-gemcitabine $\mathbf{6 7}$ with $\mathrm{BzCl}$ in the presence of DMAP and 2,6-lutidine yielded 3' and 5' protected nucleoside 68 (77\%). Oxidation of the benzoyl protected 4- $\mathrm{N}$-alkyl-gemcitabine $\mathbf{6 8}$ with $\mathrm{NMO}$ in the presence of catalytic $\mathrm{OsO}_{4}$ gave terminal vicinal diol 69 (96\%). Subsequent regioselective mesylation of the terminal primary hydroxyl $\left(\mathrm{MsCl} / \mathrm{Et}_{3} \mathrm{~N} /-20^{\circ} \mathrm{C}\right)$ gave mono-mesylated compound $\mathbf{7 0}(55 \%)$. Analogously, terminal vicinal diol 69 was treated with tosyl chloride in the presence of $\mathrm{Et}_{3} \mathrm{~N}$ to make regioselectively mono-tosylated compound 71 (62\%). Subsequently, oxidation of 70 or 71 with Collins reagent $\left(\mathrm{CrO}_{3}\right.$, pyridine and $\left.\mathrm{Ac}_{2} \mathrm{O}\right)$ gave mesyl $\beta$-keto derivative 72 (93\%) or tosyl $\beta$-keto derivative 73 (94\%, Scheme 18). 


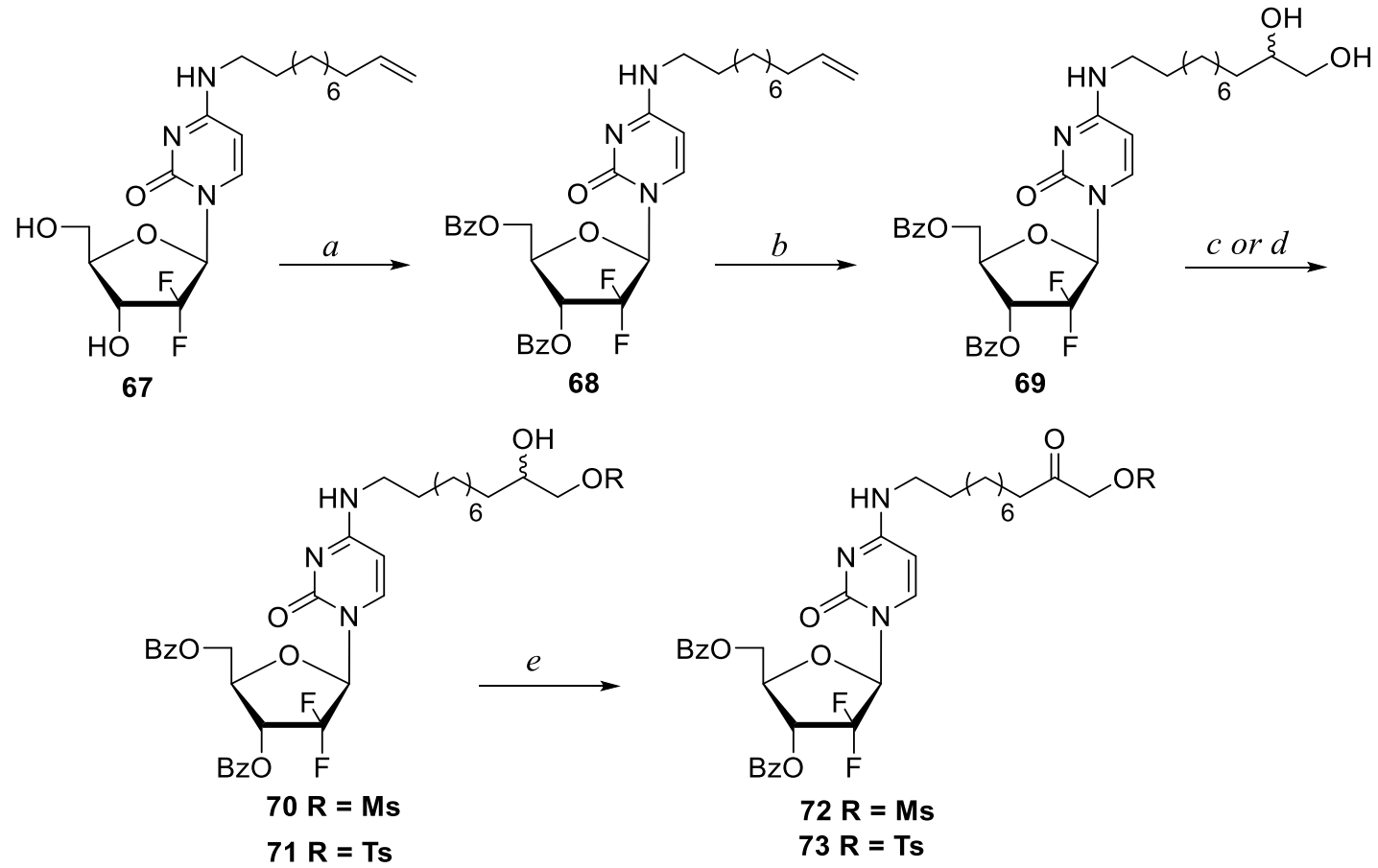

${ }^{a}$ Reagents and Conditions: (a) BzCl/DMAP/2,6-lutidine/DCM; (b) $\mathrm{OsO}_{4} / \mathrm{NMO} /$ Acetone $/ \mathrm{H}_{2} \mathrm{O}$ (10:1); (c) $\mathrm{MsCl}$ (1.1 eq.) $/ \mathrm{Et}_{3} \mathrm{~N} / \mathrm{DCM}$; (d) TsCl/DMAP/Pyr (e) $\mathrm{CrO}_{3} / \mathrm{pyr} / \mathrm{Ac}_{2} \mathrm{O} / \mathrm{DCM}$

Scheme 18. Overall synthesis of $\beta$-keto gemcitabine sulfonate analogue

\subsubsection{4- $N$-Alkyl $\beta$-keto sulfonate gemcitabine analogue: Fluorination studies}

The $\beta$-keto sulfonates $\mathbf{7 2}$ and $\mathbf{7 3}$ were subjected to the same fluorination conditions (18-crown-6, KF) at different temperatures with the ultimate goal of finding the optimal fluorination conditions. Table 2 shows a summary of the reactions that were attempted. Briefly, temperature was found to be critical for this reaction. As the temperature was increased, the yield also increased. Reactions at room temperature did not yield any product (entry 1 and 5) with substrate recovered back in both cases. When comparing the two different leaving groups, tosyl showed to be the better option for its displacement with KF (entry 6) than mesyl (entry 3). Aside from yield, tosylate $\mathbf{7 3}$ provided the cleaner fluorinated product with no formation of side products. On the other hand, the fluorination 
of the mesylated $\beta$-keto $\mathbf{7 2}$ formed several biproducts in addition to the targeted $\mathbf{7 4}$. The three set of signals in ${ }^{19} \mathrm{~F}$ NMR were diagnostic for the presence of three fluorine atoms in $74[-119.41(\mathrm{~d}, J=245.1 \mathrm{~Hz}, 1 \mathrm{~F})$ and $-120.17 \mathrm{ppm}(\mathrm{br} \mathrm{d}, J=245.1 \mathrm{~Hz}, 1 \mathrm{~F})$ for the C2' gem-difluoro unit and triplet at $-227.42(\mathrm{~J}=47.7)$ for the terminal $\left.\mathrm{CH}_{2} \mathrm{~F}\right]$.
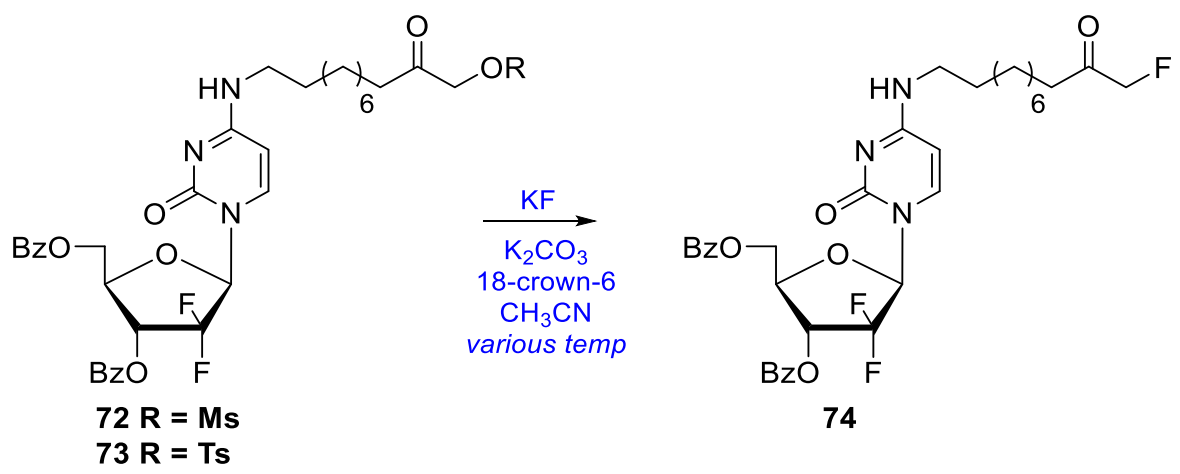

Table 2. Fluorination reactions with different conditions ${ }^{a}$

\begin{tabular}{cccccc}
\hline Entry & Sulfonate & F- source & Solvent & Temperature $\left({ }^{\circ} \mathrm{C}\right)$ & Yield (\%) \\
\hline 1 & Mesyl & $\mathrm{KF}$ & $\mathrm{CH}_{3} \mathrm{CN}$ & 20 & 0 \\
2 & Mesyl & $\mathrm{KF}$ & $\mathrm{CH}_{3} \mathrm{CN}$ & 30 & 10 \\
3 & Mesyl & $\mathrm{KF}$ & $\mathrm{CH}_{3} \mathrm{CN}$ & 60 & 40 \\
4 & Mesyl & $\mathrm{KF}$ & $\mathrm{CHCl}_{3}$ & 60 & 30 \\
5 & Tosyl & $\mathrm{KF}$ & $\mathrm{CH}_{3} \mathrm{CN}$ & 20 & 0 \\
6 & Tosyl & $\mathrm{KF}$ & $\mathrm{CH}_{3} \mathrm{CN}$ & 60 & 60 \\
\hline
\end{tabular}

$a 0.1$ mmol reaction scale, $\mathrm{KF}$ (4 eq.), $\mathrm{K}_{2} \mathrm{CO}_{3}$ (4 eq.), 18-Crown-6 (4 eq.)

After fluorination conditions were optimized, the final step was the removal of the benzoyl protection. The conditions for deprotection require fast and effective removal of the benzoyl groups, but also should be mild enough not to cause any unwanted side reactions on the fluorinated side chain. A series of reactions with model fluoro keto derivative 75 (synthesized similarly to 66; see experimental section 4.2. for detailed procedure) were performed using common debenzoylation methods (e.g., methanolic ammonia or sodium methoxide) in order to study the stability of the fluoro $\beta$-keto compounds (Table 3). Briefly, varying both the temperature and the base did not yield any 
significant decomposition in the model compound, to showing us that these bases are compatible with the required deprotection. Methanolic ammonia is a milder base than sodium methoxide (entries 1-3), but it has been shown to remove benzoyl groups from nucleosides requiring longer reaction times. The reaction time is a drawback when time sensitive radiochemical protocols need to be followed. Deprotection with sodium methoxide takes less time and also does not affect the fluorine atom of the fluoro $\beta$-keto model compound 75 (entries 4-6). It is also noteworthy that, even though model $\mathbf{7 5}$ bears the benzoyl protection, it is an amide moiety, not an ester, therefore it is less reactive and requires harsher conditions (strong acid/base) for its hydrolysis.

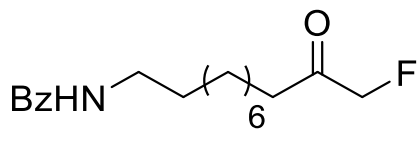

75

Table 3. Stability studies of fluoro $\beta$-keto model compound $\mathbf{7 5}$

\begin{tabular}{|c|c|c|c|c|}
\hline Entry & Base & Temperature $\left({ }^{\circ} \mathrm{C}\right)$ & Time (min) & Result \\
\hline 1 & $\mathrm{NH}_{3} / \mathrm{MeOH}$ & 0 & 30 & No change \\
\hline 2 & $\mathrm{NH}_{3} / \mathrm{MeOH}$ & 25 & 30 & No change \\
\hline 3 & $\mathrm{NH}_{3} / \mathrm{MeOH}$ & 80 & 120 & $\begin{array}{c}\text { Minimal } \\
\text { decomposition }\end{array}$ \\
\hline 4 & $\mathrm{NaOCH}_{3}{ }^{a}$ & 0 & 30 & No change \\
\hline 5 & $\mathrm{NaOCH}_{3}{ }^{a}$ & 25 & 30 & No change \\
\hline 6 & $\mathrm{NaOCH}_{3}{ }^{a}$ & 80 & 120 & $\begin{array}{c}\text { Minimal } \\
\text { decomposition }\end{array}$ \\
\hline
\end{tabular}

$a 0.5 \mathrm{M} \mathrm{NaOCH}_{3}$ in methanol

With these model studies in hand, I found that deprotection of gemcitabine analogue 74 with $\mathrm{MeOH} / \mathrm{NH}_{3}$ gave $\beta$-keto fluorine 76 (55\%, Scheme 19). The next step was simulating conventional radiosynthetic conditions with both of these substrates to prepare the deprotected fluorinated product in a short amount of time and in suitable purity. 


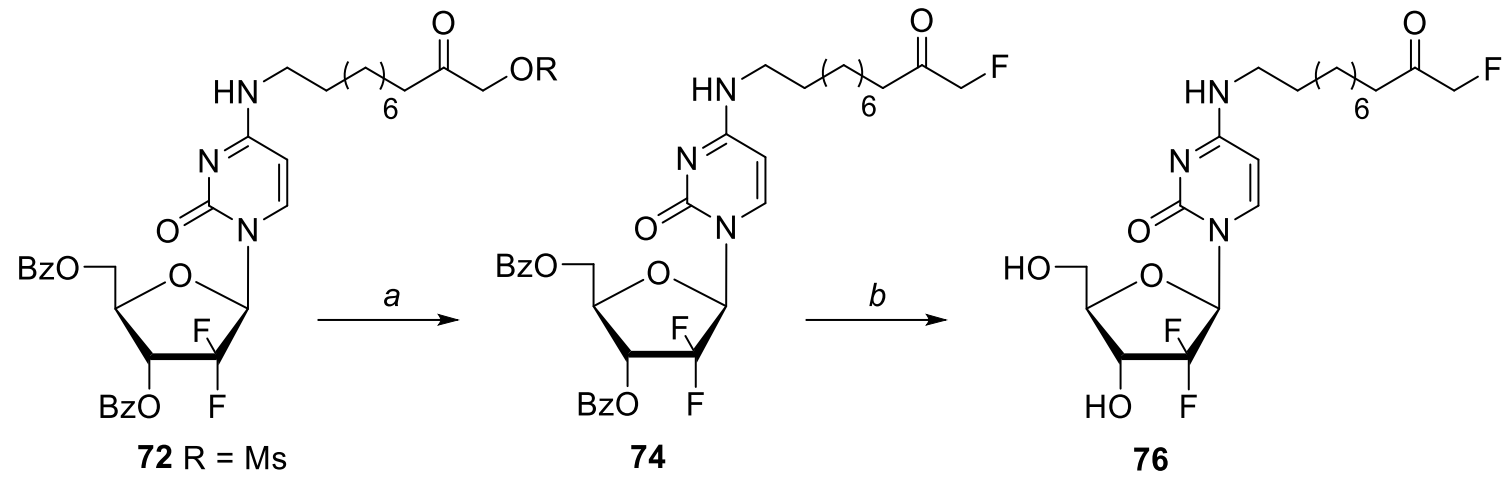

${ }^{a}$ Reagents and Conditions: a) $\mathrm{KF} / \mathrm{Kryptofix} 222 / \mathrm{CH}_{3} \mathrm{CN}, 75^{\circ} \mathrm{C}, 1 \mathrm{~h}$; b) $\mathrm{MeOH} / \mathrm{NH}_{3}, 0^{\circ} \mathrm{C}, 30$ min.

Scheme 19. Fluorination of $\beta$-keto sulfonate gemcitabine analogues and subsequent deprotection under conditions compatible with $18 \mathrm{~F}$-radiolabeling protocols ${ }^{a}$

Using both $\beta$-keto sulfonate analogues $\mathbf{7 2}$ and $\mathbf{7 3}$, attempts were made to use common 18F-radiolabeling protocols. Treatment of $\mathbf{7 2}$ or $\mathbf{7 3}$ with Kryptofix 2.2 .2 and $\mathrm{KF}\left(75^{\circ} \mathrm{C}, 30\right.$ min), followed immediately by deprotection with $\mathrm{MeOH} / \mathrm{NH}_{3}$ or $\mathrm{NaOMe}$ yielded compound 76, but at a low yield ( 25\%). Additionally, separation of the targeted compound from side products required extensive HPLC purification as a consequence of the proximities of the peaks. Also, when these steps were analyzed further, the use of Kryptofix 222 instead of 18-crown-6, another cryptand, for the fluorination step using both substrates proved to be intricate by giving several byproducts in addition to the target $\mathbf{7 6}$. Through TLC (not shown) and HPLC analysis, the fluorination of tosylated substrate $\mathbf{7 3}$ (Figure 16) was shown to cleaner than for the mesylated substrate $\mathbf{7 2}$ (Figure 17). It is expected that radiochemical yields would be even lower than those experienced in cold conditions. The RP-HPLC analysis of these reaction suggests that isolation of the desired product would be difficult. Synthesis of this $4-N$-alkyl fluoro $\beta$-keto gemcitabine analogue 
was successful, but the require fluorination and deprotection conditions coupled with the necessary extensive purification make this method impractical for medical radiolabeling.

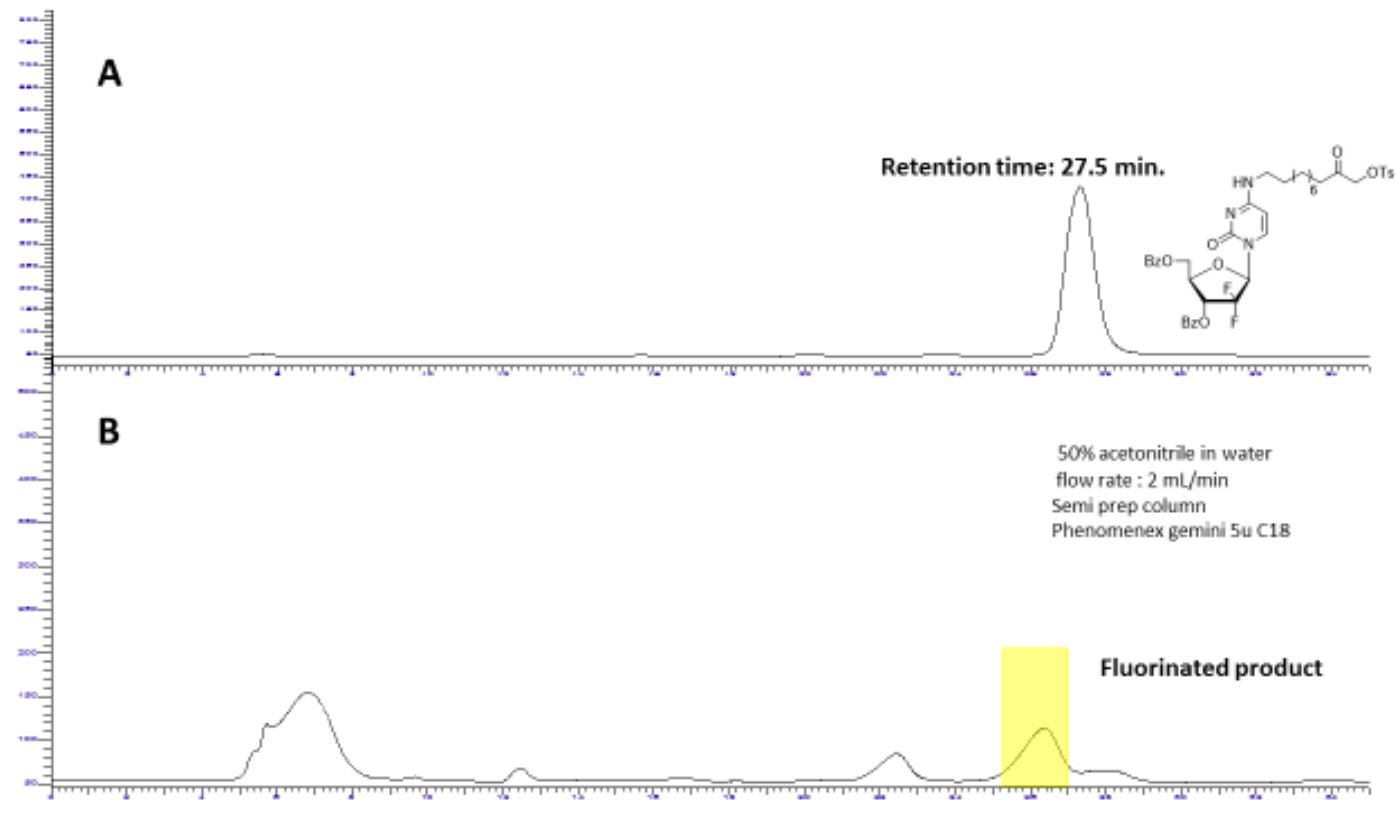

Figure 16. Fluorination of 4- $N$-alkyl 73 (chromatogram A: 73 standard, chromatogram B: Crude fluorination reaction) in $50 \% \mathrm{CH}_{3} \mathrm{CN} / \mathrm{H}_{2} \mathrm{O}$.

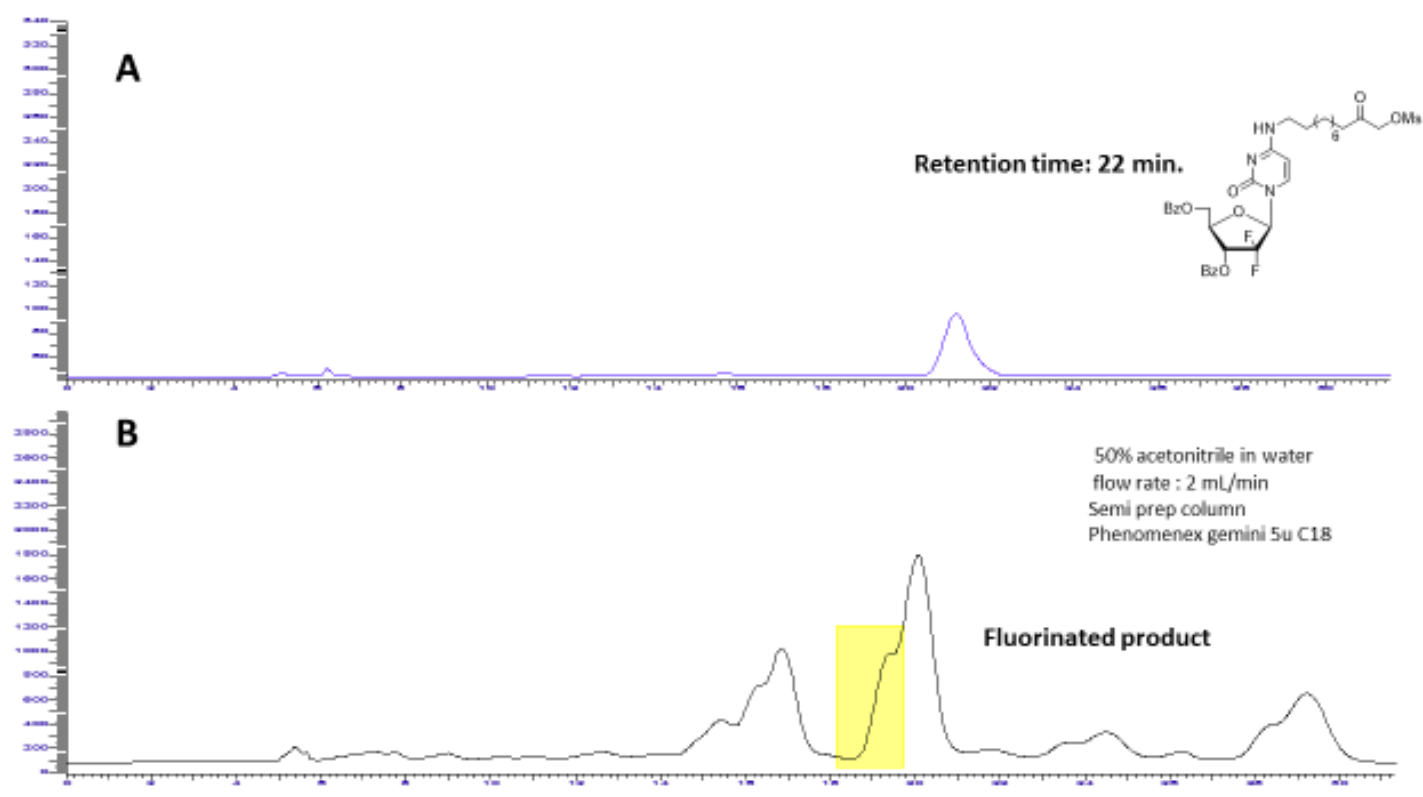

Figure 17. Fluorination of 4- $N$-alkyl 72 (chromatogram A: 72 standard, chromatogram B: Crude fluorination reaction) in $50 \% \mathrm{CH}_{3} \mathrm{CN} / \mathrm{H}_{2} \mathrm{O}$. 


\subsubsection{4- $N$-Alkyl and alkanoyl gemcitabine analogues with silicon-fluoride acceptors}

\subsubsection{Silicon-fluoride acceptors gemcitabine analogues: Rationale}

In continuation of syntheses of stable gemcitabine analogues with fluorine atom compatible for PET imaging, my next goal was the synthesis of 4- $\mathrm{N}$-modified gemcitabine analogues with silicon-fluoride-acceptor building blocks suitable for ${ }^{18} \mathrm{~F}$ radiolabeling. As it has been previously discussed, the addition of an aliphatic chain should affect pharmacodynamics and cellular uptake of the parent drug. More importantly, the use of silicon-fluoride-acceptor building block will provide another option for to study PET imaging through the "Si-F" bond which is stronger than "C-F" bond. ${ }^{87}$ Also, the "Si-F" bond, in the presence of bulky groups, is hydrolytically stable in physiological conditions (discussed in section 1.2.3.). The strategy for the synthesis of gemcitabine analogues bearing silicon fluoride acceptors attached to an exo-amino group of cytosine ring involve: (a) synthesis of gemcitabine analogues having terminal azido or alkyne group at an alkyl chain attached to 4-amino group, and (b) copper(I) catalyzed click reaction with the corresponding silane reagent having terminal alkyne or azido group, followed by its fluorination. This synthesis provide two clear advantages: $i$ ) it does not require the sugar protection of nucleoside and ii) it utilizes high-yielding copper(I)-catalyzed click chemistry. Both of these synthetic approaches lower the number of steps, have increased reaction yields and low reaction times. (Figure 18). 


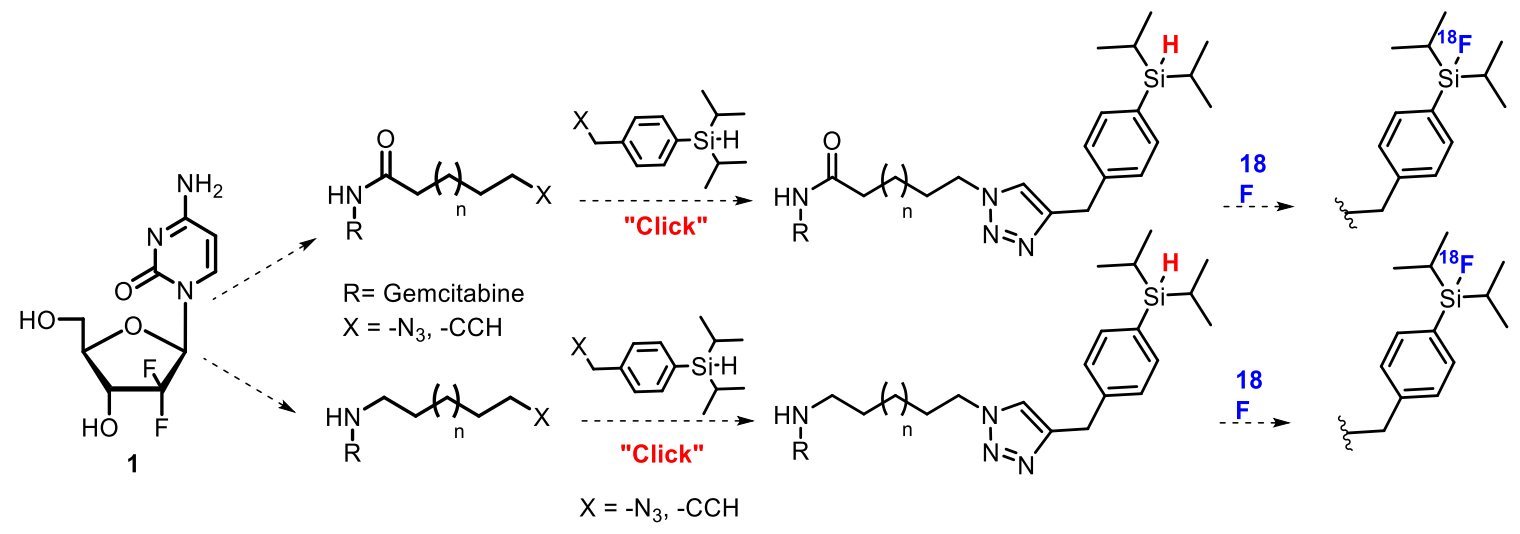

Figure 18. General synthetic goal of gemcitabine silicon-fluoride acceptors analogues

\subsubsection{Silicon-fluoride acceptors gemcitabine analogues: Synthesis}

The condensation of gemcitabine $\mathbf{1}$ with 11-azidoundecanoic acid $\mathbf{8 0}$ under peptide coupling conditions $\quad\left[(N\right.$-dimethylaminopropyl $)-N^{\prime}$-ethyl-carbodiimide $\quad($ EDC)/1hydroxybenzotriazole (HOBt)/ $N, N$-Diisopropylethylamine (DIPEA)] in DMF at $65^{\circ} \mathrm{C}$ afforded 4- $N$-(11-azidoundecanoyl)gemcitabine 81 (70\%; Scheme 21). The 11azidoundecanoic acid $\mathbf{8 0}$ was prepared by esterification of the commercially available 11bromoundecanoic acid and subsequent azidation $\left(\mathrm{NaN}_{3} / \mathrm{DMF}\right)$ followed by saponification with the overall $81 \%$ yield (Scheme 20).

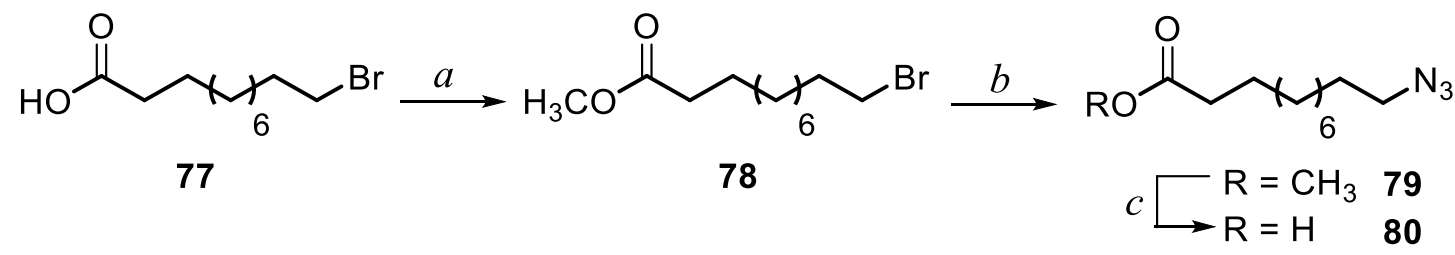

${ }^{a}$ Reagents and Conditions:(a) 2,2-Dimethoxypropane/MeOH; (b) $\mathrm{NaN}_{3} / \mathrm{DMF}$; (c) $\mathrm{NaOH} / \mathrm{MeOH}$.

Scheme 20. Synthesis of 11-azidoundecanoic acid ${ }^{a}$ 
Condensation of 1 with 5-hexynoic acid under similar conditions gave 4-N(hexynoyl)gemcitabine $\mathbf{8 2}$ but with lower yield and contaminated with mono and/or di sugar 5-hexynoate esters. However, transient protection ${ }^{45}$ of 1 with trimethylsilyl group followed by condensation with 5-hexynoic acid in the presence of EDC provided $\mathbf{8 2}^{45}$ (63\%; Scheme 21).
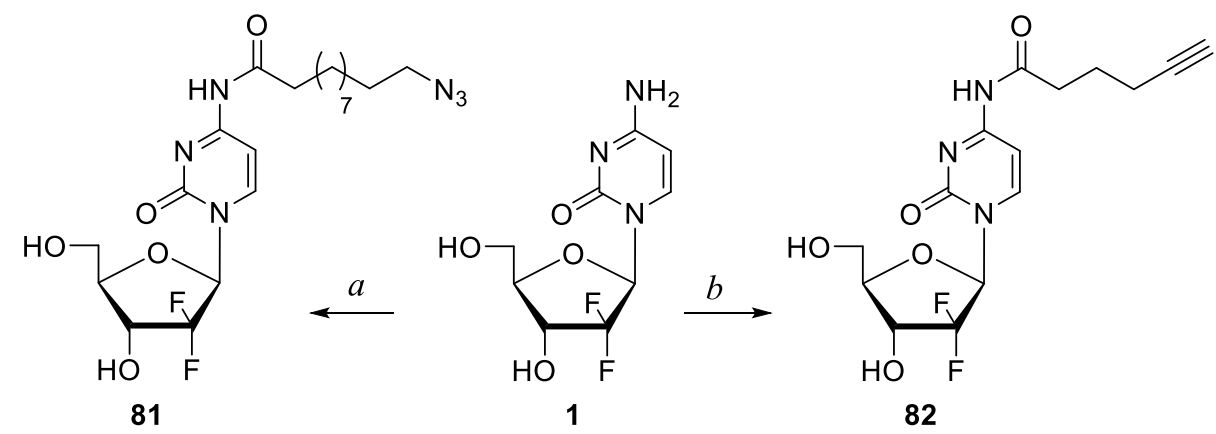

${ }^{a}$ Reactions and conditions:(a) $\mathrm{N}_{3}\left(\mathrm{CH}_{2}\right)_{10} \mathrm{COOH} / \mathrm{HOBt} / \mathrm{DIPEA} / \mathrm{EDC} / \mathrm{DMF} / 60^{\circ} \mathrm{C} /$ overnight; (b) (i) $\mathrm{TMSCl} / \mathrm{Pyr} / \mathrm{CH}_{3} \mathrm{CN}, 3 \mathrm{~h}$, (ii) $\mathrm{CHC}\left(\mathrm{CH}_{2}\right)_{3} \mathrm{COOH} / \mathrm{EDC} / \mathrm{CH}_{3} \mathrm{CN} / 65^{\circ} \mathrm{C} /$ overnight; (iii) $\mathrm{EtOH}, 45^{\circ} \mathrm{C}, 5 \mathrm{~h}$

Scheme 21. Synthesis of 4-N-alkanoyl gemcitabine substrates for click reactions ${ }^{a}$

The synthesis of the 4- $\mathrm{N}$-alkyl gemcitabine analogues with silicon-fluoride acceptor started from displacement of a 4- $\mathrm{N}$-tosylamine group from $\mathbf{6 2}$ with freshly prepared 7azidohepylamine 85. Thus, reaction of transient protected with trimethylsilyl group gemcitabine with $\mathrm{TsCl}$ in the presence of pyridine followed by deprotection with methanolic ammonia afforded protected 4-N-tosylgemcitabine ${ }^{28} \mathbf{6 2}(90 \%$, Scheme 23$)$. Treatment of $\mathbf{6 2}$ with 7-azidohepylamine 85 effected displacement of the $p$ toluenesulfonamido group from the $\mathrm{C} 4$ position of the cytosine ring to give 4- $\mathrm{N}$-(7azidoheptanyl) gemcitabine 86 (82\%). 


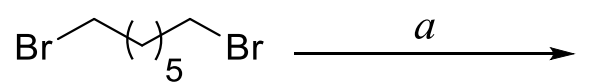

83

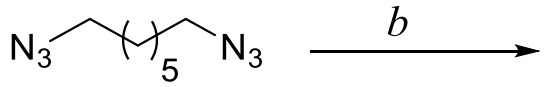

84<smiles>NCCCCCCCCCN</smiles>

85

${ }^{a}$ Reagents and Conditions:(a) (i) $\mathrm{NaN}_{3} / \mathrm{DMF}$; (b) $\mathrm{PPh}_{3} / \mathrm{EtOAc} / 5 \% \mathrm{HCl}$ (aq)

Scheme 22. Synthesis of 7-azido-1-aminoheptane ${ }^{a}$

The 7-azidoheptylamine $\mathbf{8 5}$ was prepared from 1,7-dibromoheptane by treatment with 2 eq. of $\mathrm{NaN}_{3}$, followed by selective Staudinger reduction of one of the azido group in intermediary 1,7-diazidoheptane $\mathbf{8 4}$ with triphenylphosphine in $83 \%$ overall yield (Scheme 22).

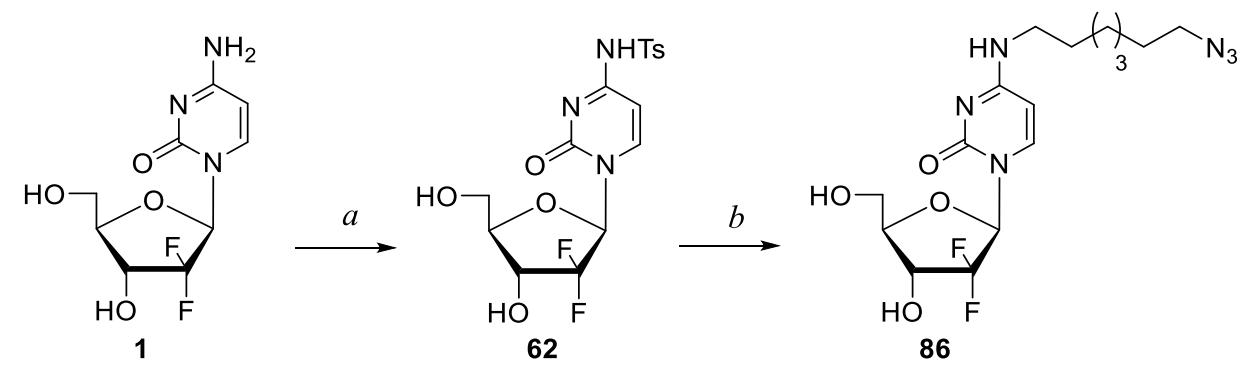

${ }^{a}$ Reagents and Conditions:(a) (i) TMSCl/Pyr, (ii) TsCl, (iii) $\mathrm{MeOH} / \mathrm{NH}_{3}$; (b) $\mathrm{N}_{3}\left(\mathrm{CH}_{2}\right)_{7} \mathrm{NH}_{2} / \mathrm{Et}_{3} \mathrm{~N} / 1$, 4-dioxane

Scheme 23. Synthesis of 4- $N$-alkyl gemcitabine derivatives for click reactions ${ }^{a}$

Two bifunctional silicon building blocks 88 and 89 (Scheme 24) were synthesized from commercially available 4-di-isopropylsilyl-benzylalcohol 87. Benzyl alcohol 87 was successively treated with mesyl chloride and $\mathrm{NaN}_{3}$ to give $\mathbf{8 8}$ (95\%). Benzyl alcohol 87 was treated with propargyl bromide in the presence of sodium hydride to give $\mathbf{8 9}(82 \%)$. 


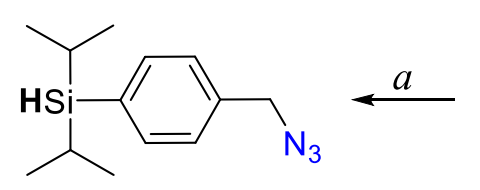

88

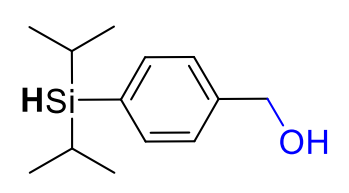

87

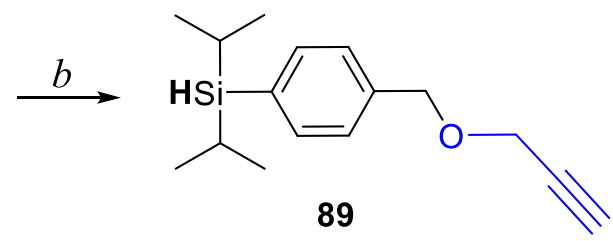

89

${ }^{a}$ Reagents and Conditions: a) (i) $\mathrm{MsCl} / \mathrm{Et}_{3} \mathrm{~N} / \mathrm{CH}_{2} \mathrm{Cl}_{2}$ (ii) $\mathrm{NaN}_{3} / \mathrm{DMF}$;

b) Propargyl Bromide/NaH/THF

Scheme 24. Synthesis of silane building blocks for click reactions ${ }^{a}$

The 4- $\mathrm{N}$-alkanoyl and 4- $\mathrm{N}$-alkyl gemcitabine analogues were then reacted with these two different bifunctional silicon-fluoride-acceptor building blocks (Scheme 25) using copper-catalyzed click reaction conditions (sodium ascorbate and copper(I) sulfate) to give $90(92 \%), 91(87 \%)$, and $92(90 \%)$.

\subsubsection{Silicon-fluoride acceptors gemcitabine analogues: Fluorination studies}

Once the silane-modified 4- $N$-alkanoyl and 4-N-alkyl gemcitabine analogues were prepared, in the next step I investigated the fluorination of these compounds with $\mathrm{KF}$, a cryptand (18-crown-6) and $\mathrm{AcOH}$ in $\mathrm{CH}_{3} \mathrm{CN}$ under a time frame compatible with ${ }^{18} \mathrm{~F}$ radiochemical reaction conditions. Model studies were performed with silicon-fluorideacceptor benzyl alcohol $\mathbf{8 7}$ using temperature and time as variables maintaining $\mathrm{KF}$ and 18-crown-6 constant (Table 4).

Table 4. Summary of model fluorination studies

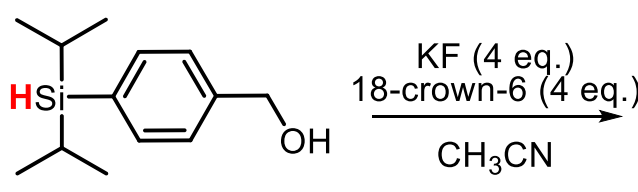

87

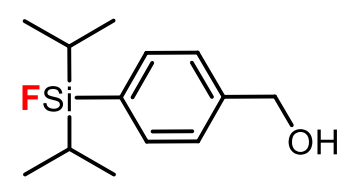

93 


\begin{tabular}{cccccc}
\hline Entry & $\begin{array}{c}\text { Temperature } \\
\left({ }^{\circ} \mathbf{C}\right)\end{array}$ & Time (min) & Fluorination? & Yield & Comments \\
\hline 1 & 30 & 30 & No & - & \\
2 & 40 & 30 & No & - & \\
3 & 60 & 20 & Yes & $20 \%$ & \\
4 & 80 & 20 & Yes & $50 \%$ & \\
5 & 80 & 20 & Yes & $60 \%$ & $\begin{array}{c}\text { Catalytic } \\
\text { AcOH added }\end{array}$ \\
\hline
\end{tabular}

Briefly, when different temperatures were tested $\left(30-80^{\circ} \mathrm{C}\right)$ it was clearly concluded that increasing temperature led to the fluorinated product $\mathbf{9 3}$ in an increased yield. Temperatures slightly above room temperature $\left(30\right.$ and $\left.40^{\circ} \mathrm{C}\right)$, did not give any product (entry 1 and 2). When the temperature was increased to $80^{\circ} \mathrm{C}$, product formed in acceptable yields (entry 4) but the addition of acetic acid $(\mathrm{AcOH})$ increased the yield even more (entry 5). When Silicon building blocks have been used as fluoride acceptors, many reports have shown that addition of acetic acid leads to an increased yield. ${ }^{89,90,94,126}$ It is important to note that the time was always kept under 30 minutes in an attempt to replicate ${ }^{18} \mathrm{~F}$ radiochemical fluorination conditions.

It is critical to mention that once the reaction time was over, the crude mixture was carefully filtered and diluted to keep the $\mathrm{pH}$ of the reaction neutral. Any deviation from neutral $\mathrm{pH}$ leads to hydrolysis of the $\mathrm{Si}-\mathrm{F}$ bond to the silanol ( $\mathrm{Si}-\mathrm{OH})$. This was clearly seen when the reactions were followed by TLC since a more polar spot appeared. After column isolation, this lower spot was shown to be the corresponding silanol by ${ }^{1} \mathrm{H}$ NMR through the absence of the Si-H peak and ${ }^{19} \mathrm{~F}$ NMR through the absence of peak at 189 ppm. This issue was discussed extensively in section 1.2.3. This model study showed that 
20 minutes at $80^{\circ} \mathrm{C}$ with the addition of acetic acid was the optimal fluorination condition and extra precautions are needed to avoid hydrolysis. This optimized fluorination condition was then applied to gemcitabine derivatives $\mathbf{9 0}, \mathbf{9 1}$ and $\mathbf{9 2}$.
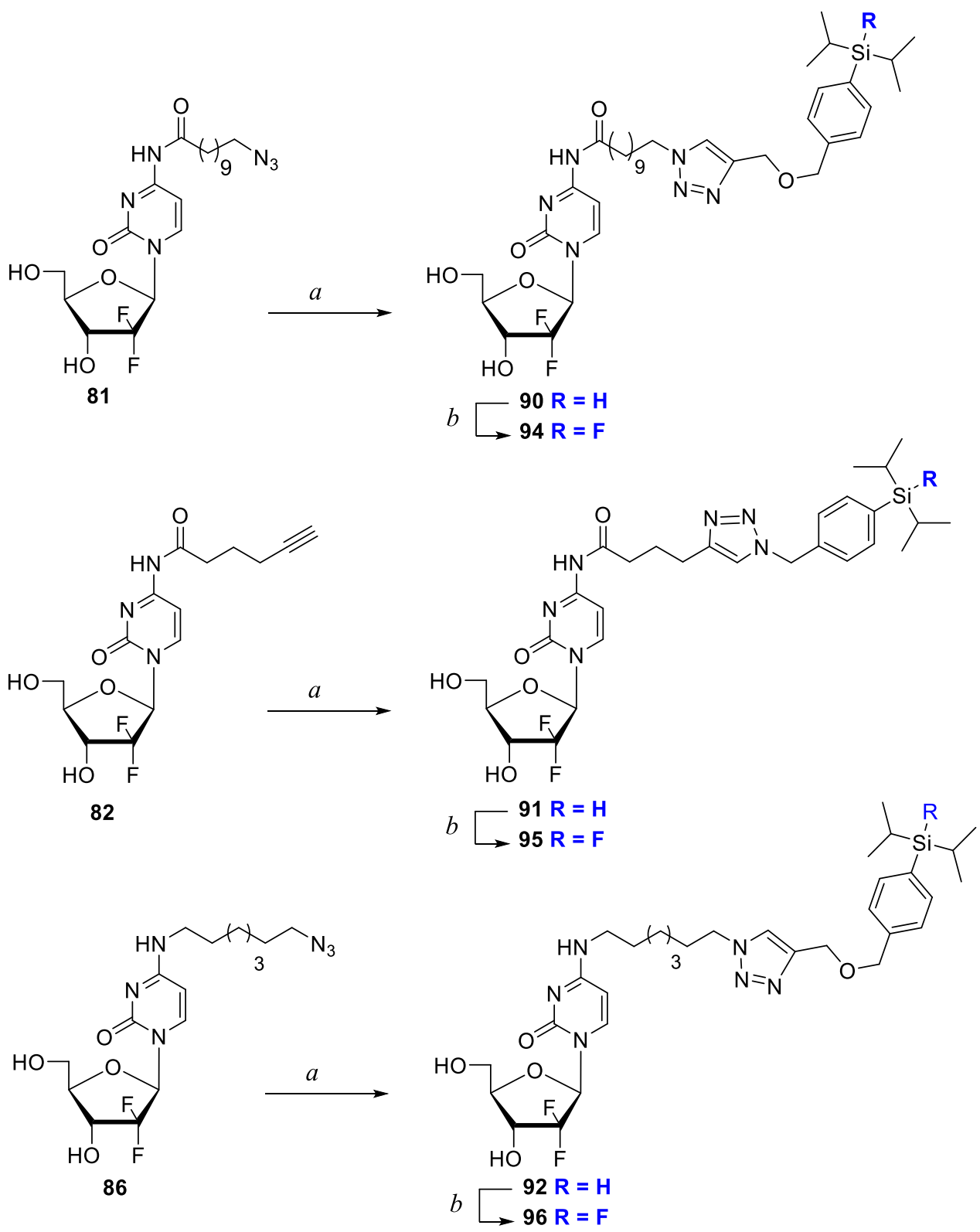

${ }^{a}$ Reagents and Conditions: (a) $\mathbf{8 8}$ or $\mathbf{8 9} /$ Sodium ascorbate $/ \mathrm{Cu}_{2} \mathrm{SO}_{4} /$ tert-butanol/water (3:1), $6 \mathrm{~h}$; (b) $\mathrm{KF} / 18$-crown- $6 / \mathrm{AcOH} / \mathrm{CH}_{3} \mathrm{CN} / 80^{\circ} \mathrm{C} / 25 \mathrm{~min}$.

Scheme 25. Synthesis of the 4- $N$-acyl/alkyl gemcitabine analogues with the siliconfluoride-acceptors ${ }^{a}$ 
Reaction of gemcitabine analogues 90,91 or 92 with KF in the presence of 18-Crown6 were carried out in $\mathrm{CH}_{3} \mathrm{CN}$ at $80^{\circ} \mathrm{C}$ for 20 min followed by quick cooling and filtration, followed by column chromatography gave their respective fluorinated products 94 (63\%), $95(65 \%)$ and 96 (62\%), respectively (Scheme 25). Besides desired 94-96, the corresponding silanols resulting from the hydrolysis of $\mathrm{Si}-\mathrm{F}$ to $\mathrm{Si}-\mathrm{OH}$ were also isolated during the purification on column ( 20-25\%). The structure of the silanols were confirmed by the absence of hydrogen from of $\mathrm{Si}-\mathrm{H}$ bond (e.g., in 96 at $3.92 \mathrm{ppm}$ ) and lack of fluorine signal (e.g., in 96 at -188.86 ppm) by ${ }^{1} \mathrm{H}$ or ${ }^{19} \mathrm{~F}$ NMR and additionally defined by HRMS. This hydrolysis was not observed in any other reaction that involved silicon-fluoride acceptors 87-89.

\subsubsection{Silicon-fluoride acceptors gemcitabine analogues: Stability studies}

Stability of 4-N-alkanoyl 90 and 4-N-alkyl 92 substrates as well as their fluorinated products 94 and 96 were examined employing RP-HPLC with isocratic mobile phase of $\mathrm{CH}_{3} \mathrm{CN} /$ water containing $0.1 \%$ of TFA which is compatible with the purification protocols for the $[18 \mathrm{~F}]$-labeled products (vide infra). In the presence of $0.1 \%$ TFA, the $4-N$-alkanoyl 90 were found to be prone to hydrolysis of the amide bond. For example gemcitabine (1015\%, $30 \mathrm{~min}$ ) was detected after 90 was dissolved in 35\% $\mathrm{CH}_{3} \mathrm{CN} / 0.1 \%$ TFA (Figure 19). 


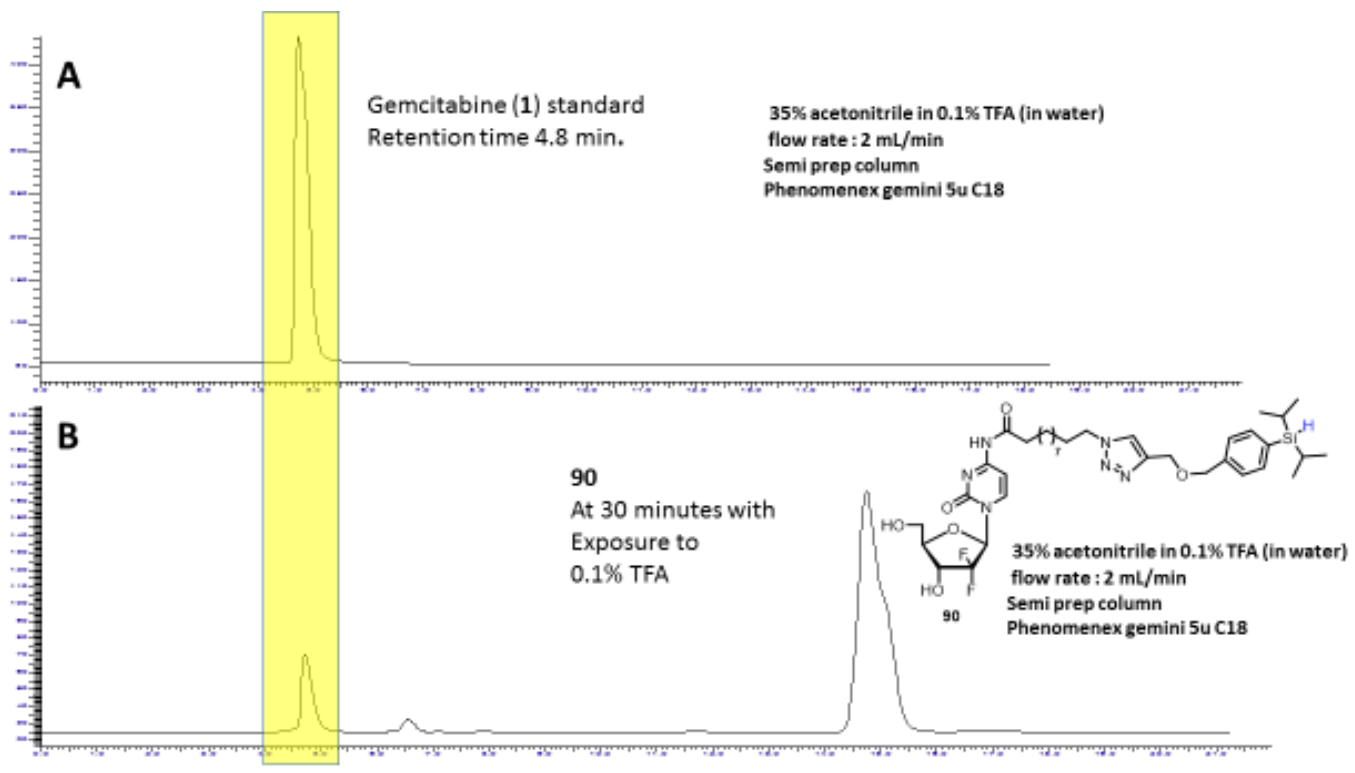

Figure 19. Stability of 4- $N$-alkanoyl 90 (chromatogram A: 1, chromatogram B: 90 after $30 \mathrm{~min})$ in $35 \% \mathrm{CH}_{3} \mathrm{CN} / 0.1 \% \mathrm{TFA}$

The RP-HPLC of the fluoro product 94 also showed hydrolysis of the acyl chain to gemcitabine $(15 \%, 30 \mathrm{~min})$ and $\mathrm{Si}-\mathrm{F}$ bond to the corresponding silanol (20\%, $30 \mathrm{~min})$. HPLC after $2 \mathrm{~h}$ showed larger amounts of silanol (30\%) and gemcitabine (20\%; Figure 20).

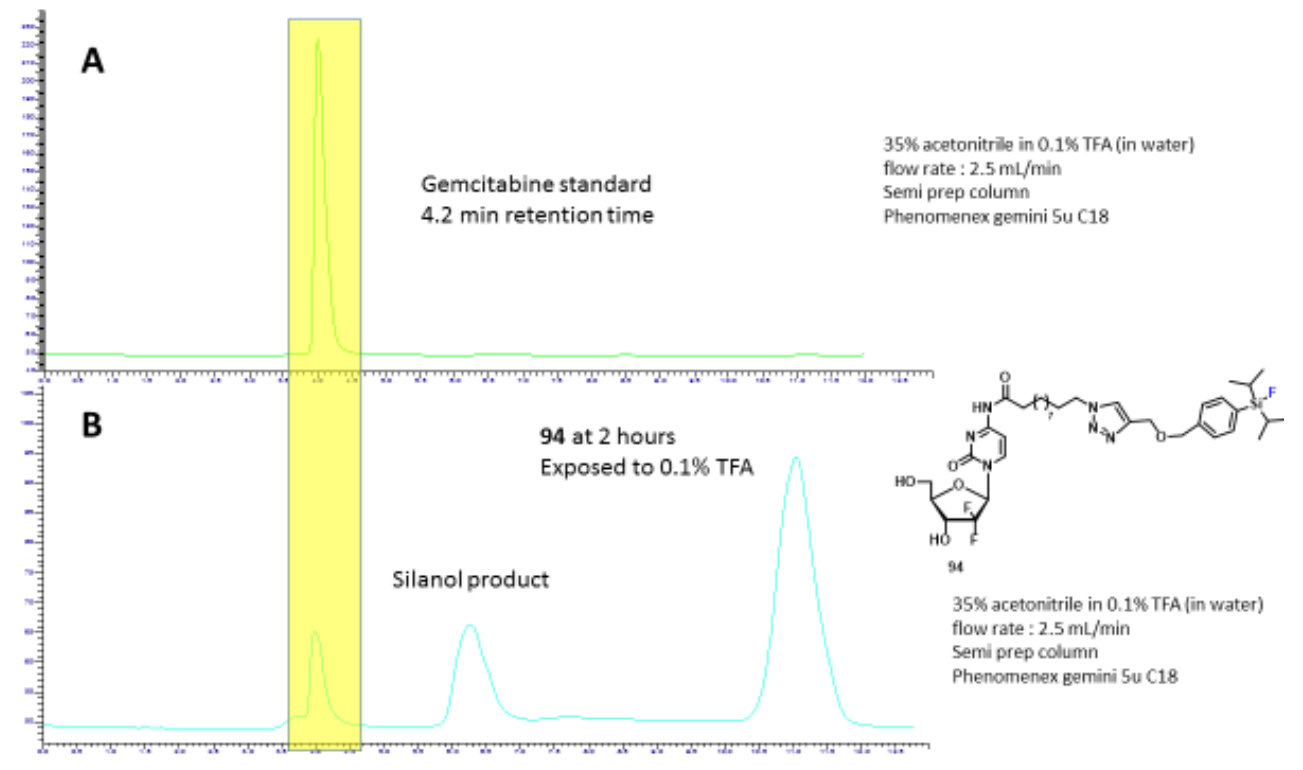

Figure 20. Stability of 4- $N$-alkanoyl 94 (chromatogram A: 1, chromatogram B: 94 after $2 h$ ) in $35 \% \mathrm{CH}_{3} \mathrm{CN} / 0.1 \%$ TFA. 
On the other hand, the 4-N-alkyl substrate 92 was found to be stable with only very minor formation of byproduct peak(s) (e.g., gemcitabine) observed after long exposure (8 h) to $35 \% \mathrm{CH}_{3} \mathrm{CN} / 0.1 \%$ TFA (Figure 21 ).

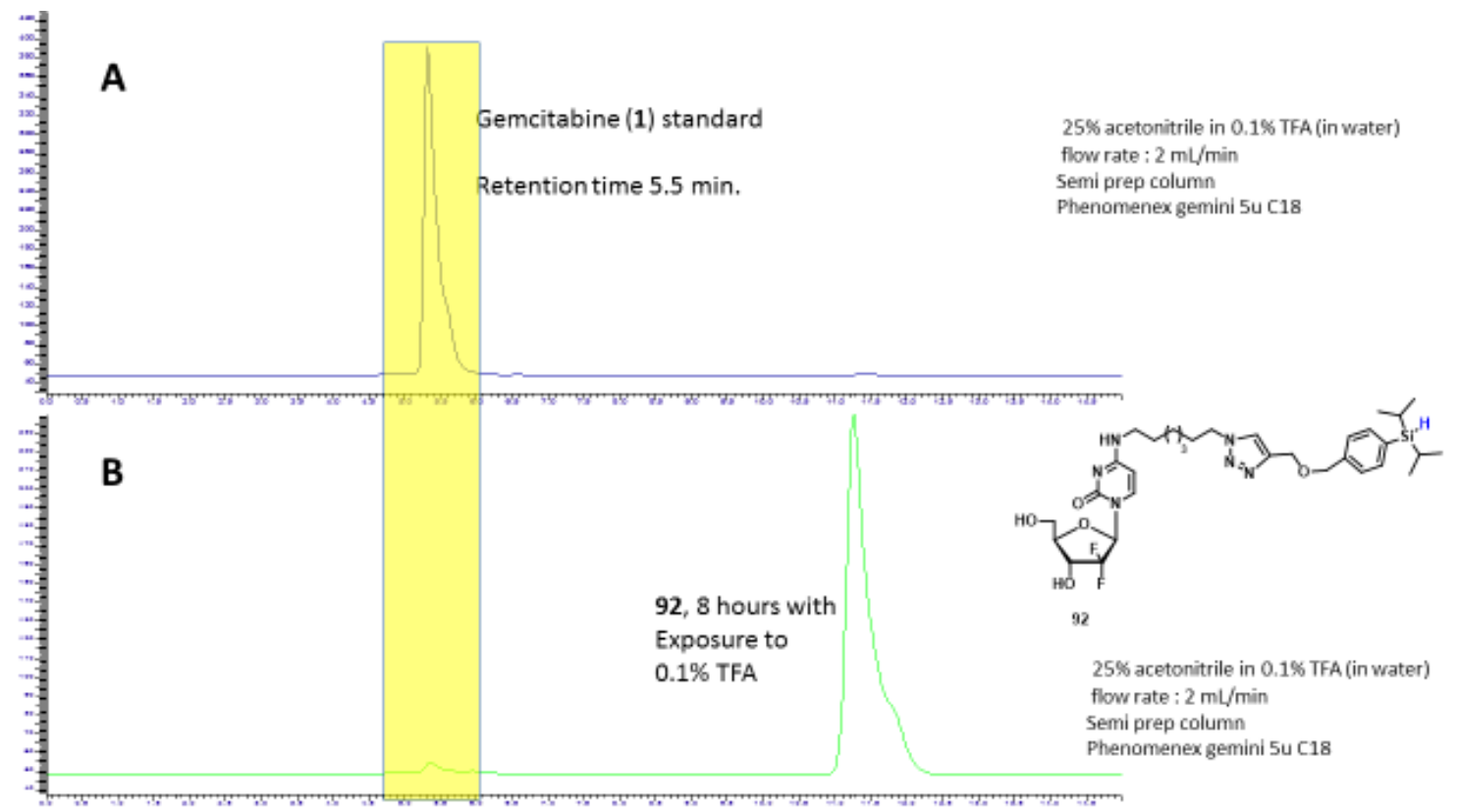

Figure 21. Stability of 4- $N$-alkyl 92 (chromatogram A: 1, chromatogram B: 92 after 8 h) in $25 \% \mathrm{CH}_{3} \mathrm{CN} / 0.1 \%$ TFA.

The fluorinated product 96 in the $25 \% \mathrm{CH}_{3} \mathrm{CN} / 0.1 \%$ TFA in water hydrolyzes to silanol $(25 \%, 1$ h, 55\%, 3 h; Figure 22). However, hydrolysis of 96 in TFA-free system (25\% $\mathrm{CH}_{3} \mathrm{CN} /$ water) occurred to a lesser extent $(25 \%, 1 \mathrm{~h}, 30 \%, 3 \mathrm{~h}$; Figure 23). These studies show that the 4- $N$-alkyl silanes and fluorosilanes are more stable under acidic conditions, indicating an advantage when discussing their potential as PET imaging agents. Moreover, the 4- $N$-alkyl derivatives have a lower chance to decompose/break down as they travel through the different environments for biological testing (cell/mice/human). 


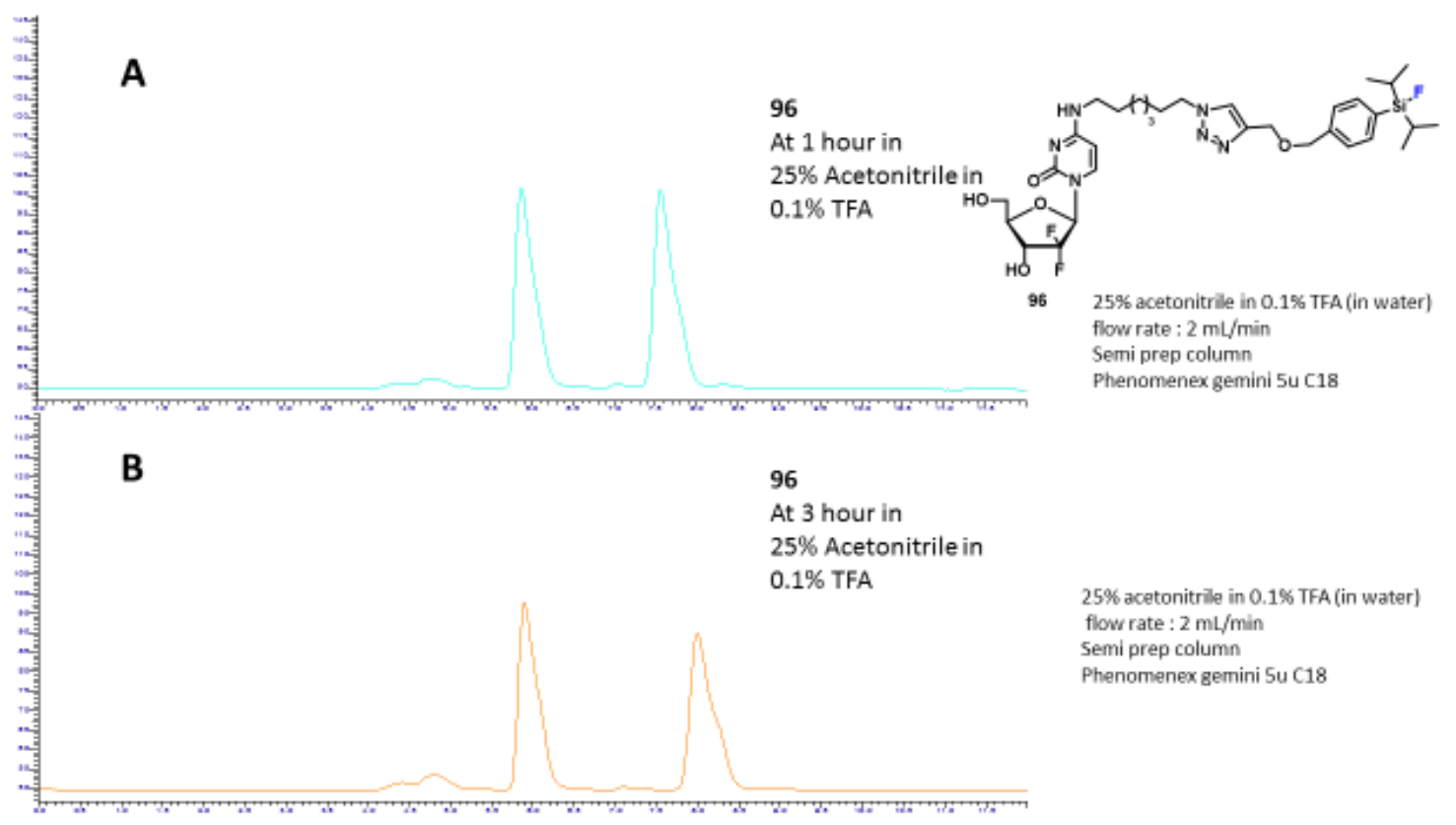

Figure 22. Analysis of stability of 4- $N$-alkyl 96 (chromatogram A: 96 after $1 \mathrm{~h}$, chromatogram B: 96 after $3 h$ ) in $25 \% \mathrm{CH}_{3} \mathrm{CN} / 0.1 \%$ TFA.

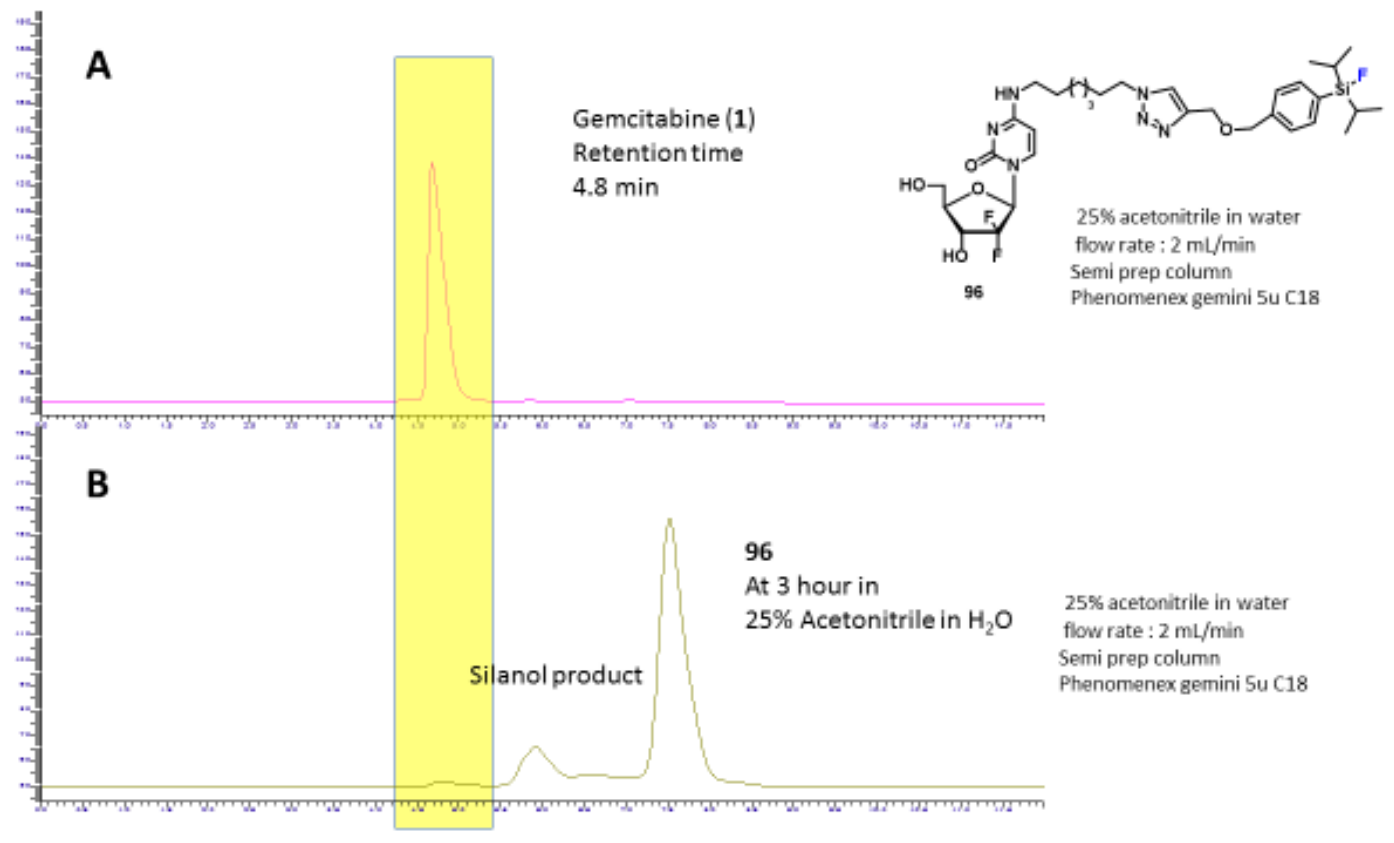

Figure 23. Analysis of stability of 4- $N$-alkyl 96 (chromatogram A: 1, chromatogram B: 96 after $3 h$ ) in $25 \% \mathrm{CH}_{3} \mathrm{CN} / \mathrm{H}_{2} \mathrm{O}$ (NO TFA). 


\subsubsection{Biological evaluation of the $4-N$-alkyl \& alkanoyl gemcitabine analogues}

The biological aspect of the 4-N-alkanoyl and 4- $N$-alkyl gemcitabine analogues was 1) assess their cytotoxic activity through preliminary biological evaluations in cancer cell lines; 2) to assess their cell permeability, due to their lipophilic nature; 3) to examine their resistance to deamination from cytosine to uracil base; and 4) to study their rate of hydrolysis to the parent gemcitabine. All of these points would reflect a change in the pharmacokinetics and more importantly, the anti-cancer potency of the designed analogues compared to the parent drug. Some of these pharmacokinetics deviations have been observed and reported in 4- $N$-alkanoyl derivatives ${ }^{21,24}$ and to a much lesser extent with 4$N$-alkyl analogues. ${ }^{28}$ Most of the examples in literature are lipophilic 4 - $N$-alkanoyl gemcitabine analogues, with focus on their resistance to deamination as well as slow hydrolysis for a slow release to the parent drug. ${ }^{19,21,24} 4-\mathrm{N}$-alkyl modifications have shown to be chemically and enzymatically resistant to cleavage, therefore having little to no release of gemcitabine, showing very little biological effect on cells. ${ }^{28}$

\section{Cytostatic evaluation of 4- $\mathrm{N}$-modified gemcitabine analogues}

In collaboration with the Ramachandran's group at Nicklaus Children Hospital, Miami Children's Health System cytostatic activities of the 4- $\mathrm{N}$-modified gemcitabine analogues 81, 86, 90, 91, 92 and 94 were analyzed in L1210 mouse lymphocytic leukemia cell line. All compounds were directly tested in free-base form, and were found to have different levels of inhibition in a dose-dependent manner. This is demonstrated by the cytostatic activity curves in Figure 24 and Table 5. The $4-N$-alkylgemcitabines 86 and 92, with both $\mathrm{IC}_{50}>200 \mu \mathrm{M}$, demonstrated no cytostatic activities in L1210 cells (after $72 \mathrm{~h}$ incubation) in comparison to the 4- $N$-alkanoylgemcitabine analogues 81, 90, 91 and 94 with $\mathrm{IC}_{50}=$ 
$7.99 \mu \mathrm{M}, \mathrm{IC}_{50}=7.47 \mu \mathrm{M}, \mathrm{IC}_{50}=65.3 \mu \mathrm{M}$ and $\mathrm{IC}_{50}=39.96 \mu \mathrm{M}$ respectively. These results confirmed what previous studies have shown, that the 4- $\mathrm{N}$-alkanoylgemcitabine analogues do undergo slow hydrolysis and release the parent gemcitabine for DNA incorporation and apoptosis. In the case of the 4- $\mathrm{N}$-alkylgemcitabine analogues, there appears to be no such release of the parent drug, leading to the small biological effect on the L1210 cells studied. These results also in conformity with our group's previous studies in other 4-N-alkyl gemcitabine analogues. ${ }^{28,38}$ With these results in hand, we were intrigued in the outcome of the 4- $N$-alkyl analogues.

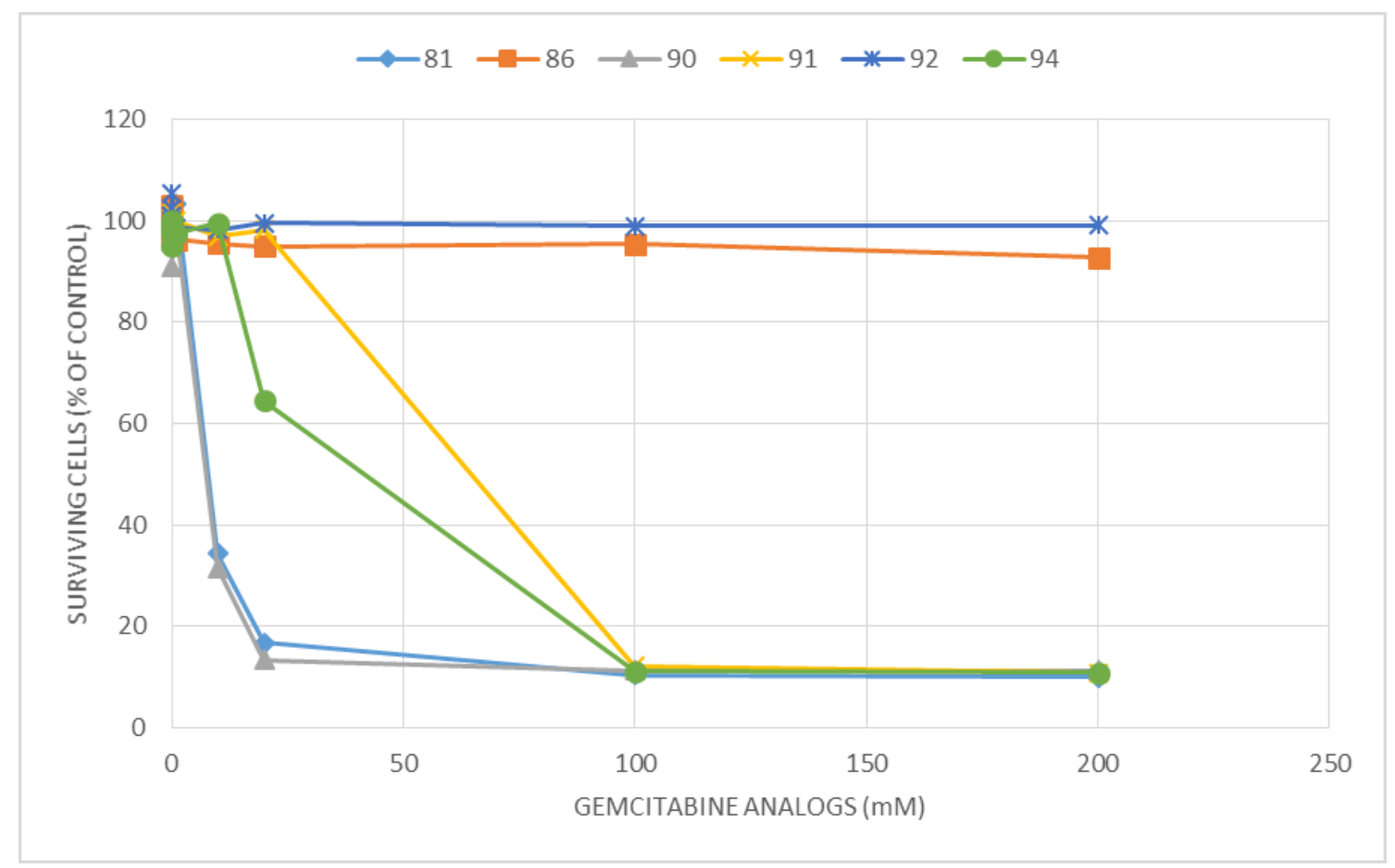

Figure 24. In vitro cytotoxicity curve of $4-N$-alkanoyl and 4- $N$-alkyl gemcitabine analogues on L1210 mouse leukemic cell lines. Cells were treated with analogues for $72 \mathrm{~h}$ before the viability of treated cells was determined by MTT assay. Results represent the mean of triplicates with error bars indicating standard deviation. 
Table 5. In vitro cytostatic activity of 4- $N$-modified gemcitabine analogues on L1210 cell line

\begin{tabular}{ccc}
\hline Analogs & IC $_{50}(\boldsymbol{\mu M})$ & IC75 $_{\mathbf{7}}(\boldsymbol{\mu M})$ \\
$\mathbf{8 1}$ & $7.99 \pm 0.41$ & $14.87 \pm 2.40$ \\
$\mathbf{8 6}$ & $>200$ & $>200$ \\
$\mathbf{9 0}$ & $7.47 \pm 0.41$ & $13.33 \pm 1.14$ \\
$\mathbf{9 1}$ & $65.3 \pm 0.61$ & $88.33 \pm 1.15$ \\
$\mathbf{9 2}$ & $>200$ & $>200$ \\
$\mathbf{9 4}$ & $39.96 \pm 1.95$ & $78.33 \pm 5.51$ \\
\hline
\end{tabular}

Additionally, in collaboration with Dr. Barbieri from FIU Department of Biological Sciences, we tested cell proliferation of gemcitabine $\mathbf{1}$ as well as the 4 - $N$-alkyl modified gemcitabine analogues 86 and 92, and 4- $N$-alkanoyl 81 and 92 in HEK 293 cell line (48h). Again, all compounds were directly tested in free-base form, and were found to have different levels of inhibition in a dose dependent manner. As with the L1210 cell line, as the concentration of the nucleosides was increased (50 to $100 \mu \mathrm{M}$ ), cell proliferation decreased. Furthermore, all of the 4-N-modified gemcitabine analogues showed lower proliferation than the parent drug (57-21\% in $50 \mu \mathrm{M}$ versus $64 \%$ in $50 \mu \mathrm{M}$ gemcitabine; Figure 25). This evidently shows that the addition of the lipophilic chain, either in the alkanoyl or alkyl analogues, affords a greater incorporation of the drug into cells. Also, these results might be due to HEK 293 cells having higher specific activity of CDA, than that reported for many other cells and organs, than that reported for many other cells and organs. In many tumoral tissues/cells, the CDA activity is lower than $0.1 \mathrm{mU} / \mathrm{mg}^{127,128}$ Additionally, CDA activity is present at higher levels in human cell lines than in rodents (L1210 cell line). ${ }^{129,130}$ This increase in CDA activity might explain the relatively low gemcitabine cytotoxicity but it does not explain the higher cytotoxicity of the 4- $\mathrm{N}$ - 
gemcitabine analogues, other than show their lack of potential as CDA substrates. At this moment, no further conclusion can be made about these results, and future studies in this cell line as well as other cancer cell lines is required.

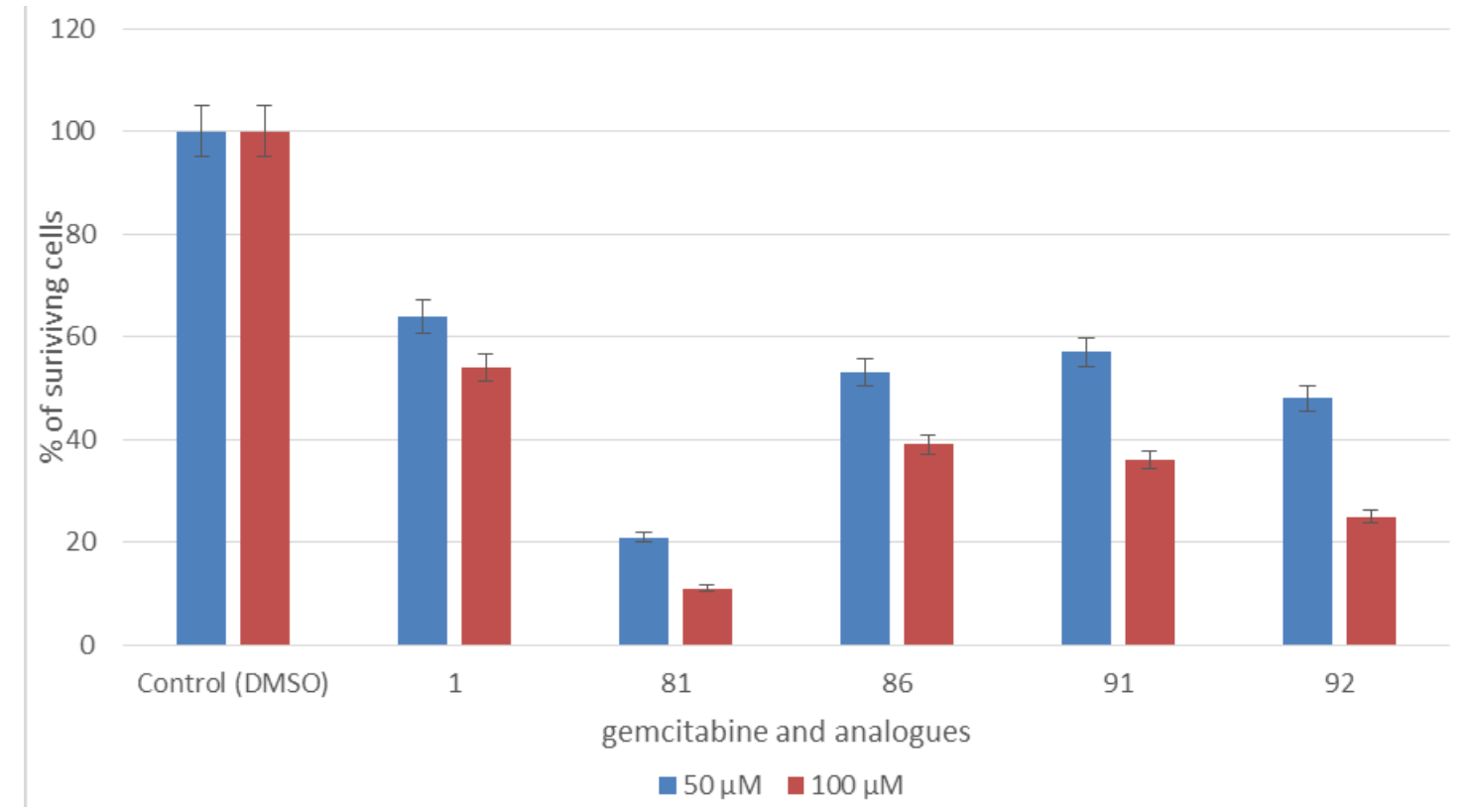

Figure 25. In vitro cytotoxicity graph of 4- $N$-alkanoyl ( $\mathbf{8 1} \& \mathbf{9 1})$ and $4-N$-alkyl (86 \& 92) gemcitabine analogues on HEK 293 cell lines. Cells were treated for $48 \mathrm{~h}$ before the viability of treated cells was determined by MTT assay. Results represent the mean of triplicates

\section{4- $N$-Alkylgemcitabine analogues membrane permeability studies}

As previously discussed, studies done by Pulido et al. showed 4- $N$-alkylgemcitabines $\mathbf{9}$ and $\mathbf{1 0}$ showed relatively weak to modest cytostatic activity in a number of cancer cell lines due to a lack of conversion to gemcitabine. ${ }^{28}$ These outcome with this type of analogue was not clear, and it was assumed that $4-\mathrm{N}$-alkylgemcitabines either undergo a different metabolic process or a cellular uptake was poor. In collaboration with Dr. Barbieri, we studied a series of biological experiments to better understand the outcome/effect of 4- $\mathrm{N}$-alkylgemcitabine analogues in cells. 


\section{Cell Permeability: 4-N-Alkylgemcitabine analogue 86 HPLC studies}

We decided to monitor the outcome of the analogue 86 after $24 \mathrm{~h}$ incubation period in HEK 293 human embryonic kidney cell line. The initial goal of this experiment was to investigate if 4- $\mathrm{N}$-alkylgemcitabine analogues enter the cells, and if so, are they being hydrolyzed to the parent molecule, leading to incorporation in DNA or were they trapped in the cell and/or nucleus. Analogue $\mathbf{8 6}$ was used as a model and HPLC analysis was performed to examine if the analogue is incorporated into the cell.

After $24 \mathrm{~h}$ incubation of HEK 293 cells with 86, the culture medium, which contained the gemcitabine analogue and the cells adhered to the flask were separated. The cells were then lysed. With the two samples in hand, each was then extracted with an organic solvent to recover the analogue and analyzed using reversed-phased HPLC by comparing each sample to the retention time of standard $\mathbf{8 6}$ (25 min, Figure 26).

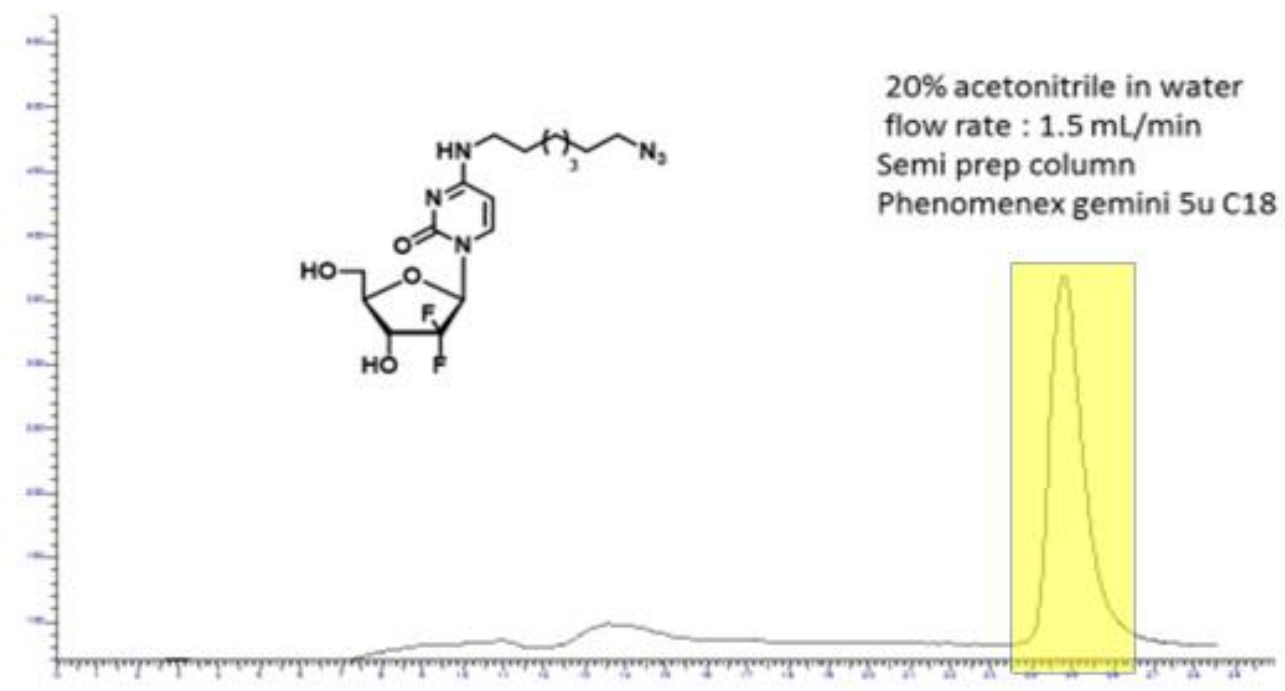

Figure 26. HPLC chromatograph of 86 in $20 \% \mathrm{CH}_{3} \mathrm{CN} / \mathrm{H}_{2} \mathrm{O}$

HPLC analysis was done of three samples: the blank cell sample that did not contain 86, the cell culture and cell sample of HEK 293 cells after they were incubated with $\mathbf{8 6}$ for 
24 hours. The results clearly confirm that in both the cell culture sample, and the cell sample contained $\mathbf{8 6}$. These results evidently demonstrate that $\mathbf{8 6}$ passes through the cell and even after $24 \mathrm{~h}$ of incubation, does not undergo hydrolysis (Figure 27).

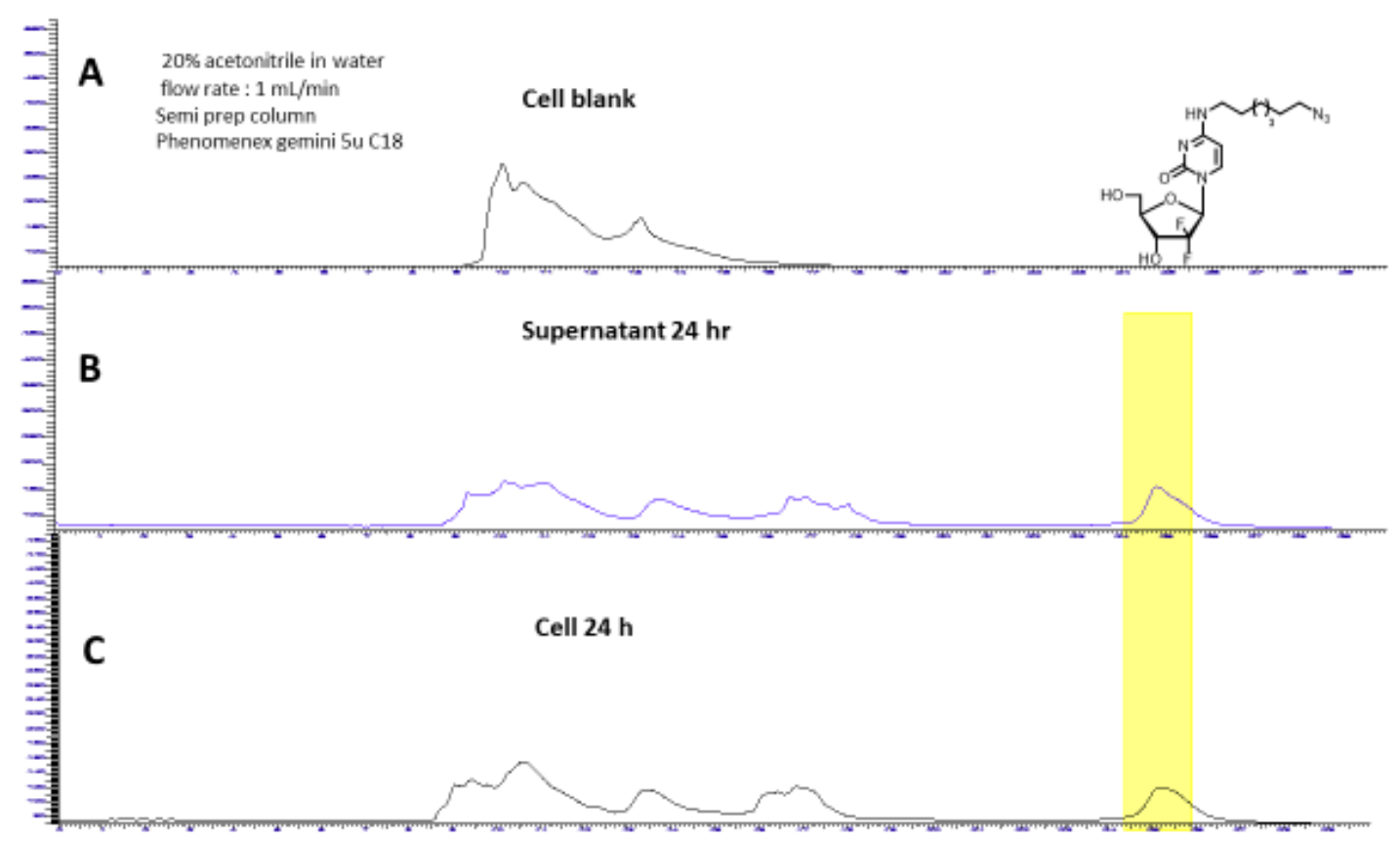

Figure 27. HPLC analysis of 86 in $\mathrm{CH}_{3} \mathrm{CN} / \mathrm{H}_{2} \mathrm{O}$ after incubation in $\mathrm{HEK} 293$ cell line (chromatogram A: cell blank, chromatogram B: supernatant after 24 h, chromatograph $C$ : cell sample after $24 \mathrm{~h}$ ) in $20 \% \mathrm{CH}_{3} \mathrm{CN} / \mathrm{H}_{2} \mathrm{O}$.

\section{Cell Permeability: Fluorescence microscopy studies with 4-N-Alkylgemcitabine analogue 86}

In addition to the HPLC analysis of incorporation of $\mathbf{8 6}$ into the cell, we decided to use confocal fluorescence microscopy in order to visualize where in the cell $\mathbf{8 6}$ is incorporated. Specifically, we wanted to evaluate the ability of $\mathbf{8 6}$ to be metabolically incorporated into the cell by exploring its ability to be used for click chemistry.

Visualization of cells, its components and its interaction with small and large biomolecules such as proteins, peptides and nucleosides have been done through the use of highly fluorescent probes. ${ }^{131-135}$ These probes or dyes, which are fluorophores, are typically 
designed to react within a specific region of the sample, such as a specific functional group like amines or thiols, or in my case, an azido group for a copper catalyzed click reaction (CuAAC) with a fluorescent dye that contains a terminal alkyne. ${ }^{136,137}$

HEK 293 cells were treated with $100 \mu \mathrm{m}$ of $\mathbf{8 6}$ for 24 h, fixed, and stained with Fluor 488 alkyne in the presence of copper(I) in order to perform a click reaction with the azido bearing 86. If the click reaction occurs in the cell, we would then observe fluorescence, which would then demonstrate that $\mathbf{8 6}$ crosses the cell membrane but also show where in the cell $\mathbf{8 6}$ is incorporated and trapped (Figure 28).

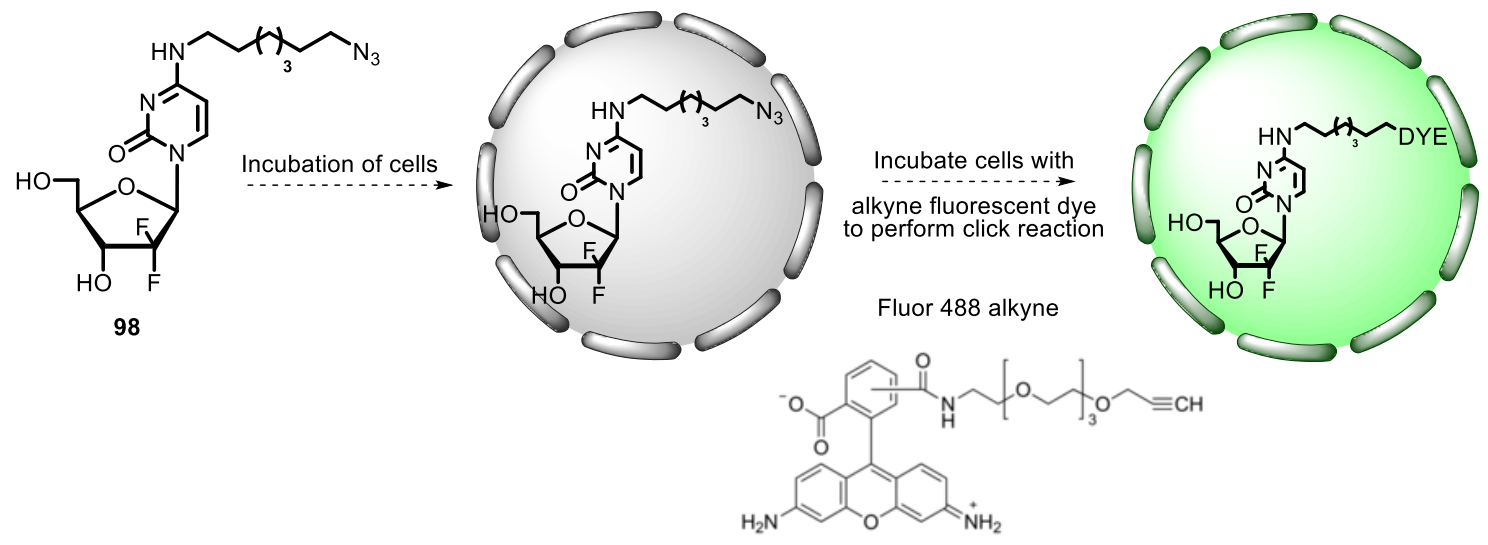

Figure 28. General outline for fluorescence labeling experiment

Incubation of HEK 293 cells with 4- $N$-alkylgemcitabine 86 followed by treatment with Fluor 488 alkyne was successful after 1 hour and exhibited strong CuAAC staining (seen in green) that colocalized with the strong nuclear noncovalent stain DAPI (seen in blue, Figure 29). This shows that $\mathbf{8 6}$ is incorporated into the cell but also trapped in the nucleus (seen through DAPI staining). Additionally, it appears that it does not undergo hydrolysis compared to 4- $\mathrm{N}$-alkanoylgemcitabine analogues. In their design, it appears that 4- $\mathrm{N}$-alkyl analogues are not substrates for $\mathrm{dCK}$, as the cytotoxicity activity in L1210 cells are low, 
but chemical stability is gained. In accordance with the HPLC stability studies, our imaging studies show that 4-N-alkyl are stable and that they are trapped inside the cell/nucleus. Based on the activity of 4-N-alkanoyl analogues of gemcitabine, whose lipophilicity are similar to our 4- $\mathrm{N}$-alkyl analogues, we can expect that the 4- $\mathrm{N}$-alkyl analogues would be up taken by variety types of cells but have a lower chance to decompose/break down as they travel through the different environments for biological testing (cell/mice/human), including PET imaging.

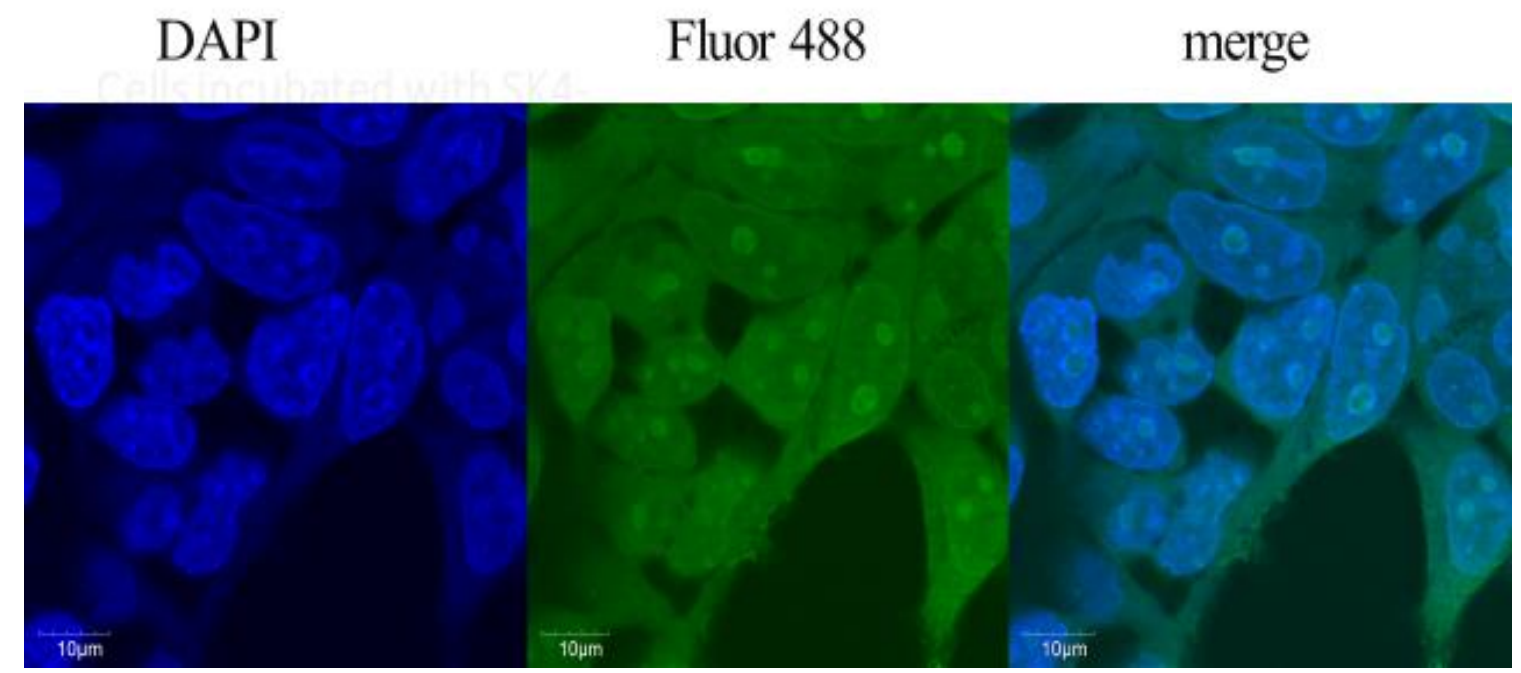

Figure 29. Labeling of 86 in HEK 293 cells for 24 h, followed by fixation and addition of Fluor 488 alkyne and copper(I).

\subsubsection{6. $\left[{ }^{18} \mathrm{~F}\right]$-Labeling of $4-N$-alkanoyl and alkyl gemcitabine radioligands}

Following cold fluorination studies, radiosynthesis of $\left[{ }^{18} \mathrm{~F}\right]-4-N$-alkanoyl and alkylgemcitabine radioligands 94 and 96 were performed in the laboratory of Dr. Michael van Dam from the Crump Institute for Molecular Imaging using macroscale and microscale in simple microfluidic chip protocols. 


\section{Macroscale radiosyntheses of 4- $N$-alkanoyl $\left[{ }^{18} \mathrm{~F}\right] 94$ and 4- $N$-alkyl $\left[{ }^{18} \mathrm{~F}\right] 96$}

The one-pot syntheses of 4- $N$-alkanoyl $\left[{ }^{18} \mathrm{~F}\right] \mathbf{9 4}$ and $4-N$-alkyl $\left[{ }^{18} \mathrm{~F}\right] \mathbf{9 6}$ were performed on the ELIXYS FLEX/CHEM radiosynthesizer and adapted from literature. ${ }^{99}$ Thus, by adding silane precursor $\mathbf{9 0}$ in DMSO with $1 \% \mathrm{v} / \mathrm{v} \mathrm{AcOH}$ to the previously dried $\left[{ }^{18} \mathrm{~F}\right] \mathrm{KF} / \mathrm{K}_{222}$ complex and reacting at $100^{\circ} \mathrm{C}$ for $25 \mathrm{~min}$, followed by HPLC purification, 4- $N$-alkanoyl $\left[{ }^{18} \mathrm{~F}\right] 94$ in $~ 0.5 \%(\mathrm{n}=1)$ decayed-corrected crude radiochemical yield (Table 6, Figure 30). Analogously, the $\left[{ }^{18} \mathrm{~F}\right]$ fluorination of precursor 92 gave $4-N$-alkyl $\left[{ }^{18} \mathrm{~F}\right] \mathbf{9 6}$ with $6.6 \pm 3.2 \%(\mathrm{n}=5)$ decayed-corrected isolated yield and $>99 \%$ radiochemical purity.(Figure 31, see experimental section for more detailed protocol).

Scheme 26. Radiosynthesis of $\left[{ }^{18} \mathrm{~F}\right]$ 4- $N$-alkanoyl and alkyl gemcitabine analogues with silicon-fluoride acceptors<smiles>CCCOCc1ccc([SiH]C(C)C)cc1</smiles>

90 or 92

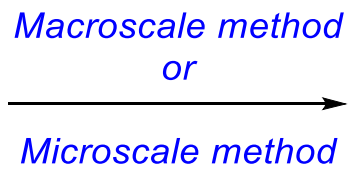

[18F] KF/K2.2.2

DMSO, AcOH (1\% v/v)

$100{ }^{\circ} \mathrm{C}, 25 \mathrm{~min}$

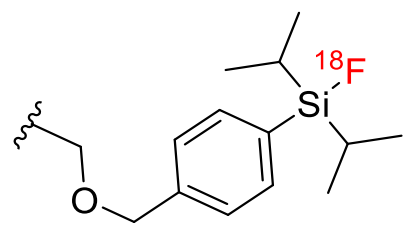

94 or 96

Table 6. ${ }^{18} \mathrm{~F}$ radiosynthetic yields of $4-N$-modified gemcitabine analogues 94 and 96

\begin{tabular}{cccc}
\hline Entry & Analogue & $\begin{array}{c}\text { Macroscale } \\
\text { radiosynthesis }^{a}\end{array}$ & $\begin{array}{c}\text { Microscale } \\
\text { radiosynthesis }^{b}\end{array}$ \\
\cline { 3 - 4 } & $\begin{array}{c}\text { Average decay- } \\
\text { corrected isolated } \\
\text { RCY }(\%)\end{array}$ & $\begin{array}{c}\text { Decayed corrected } \\
\text { crude RCY }(\%)\end{array}$ \\
1 & $\mathbf{9 4}$ & 0.5 & 10 \\
2 & $\mathbf{9 6}$ & $6.6 \pm 3.2(\mathrm{n}=5)$ & $24.4 \pm 4.1(\mathrm{n}=5)$ \\
\hline
\end{tabular}

a 2-3 mg scale reactions

$b 0.2 \mathrm{mg}$ scale reactions 


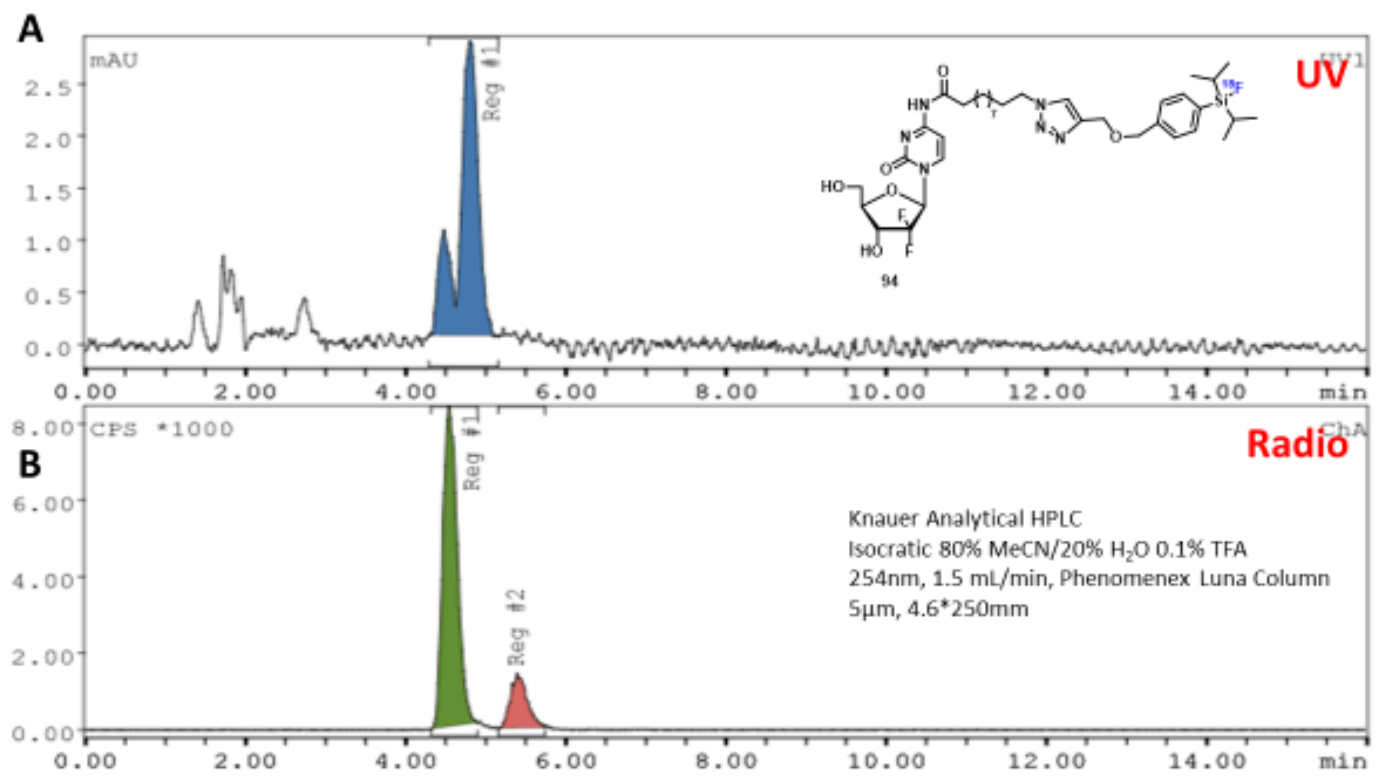

Figure 30. Macroscale radiosynthesis of 4-N-alkanoyl $\left[{ }^{18} \mathrm{~F}\right] 94$ (chromatogram $A$ : $U V$ detector, chromatogram B: gamma detector, radiolabeled product in green) in $80 \%$ $\mathrm{CH}_{3} \mathrm{CN} / 0.1 \%$ TFA

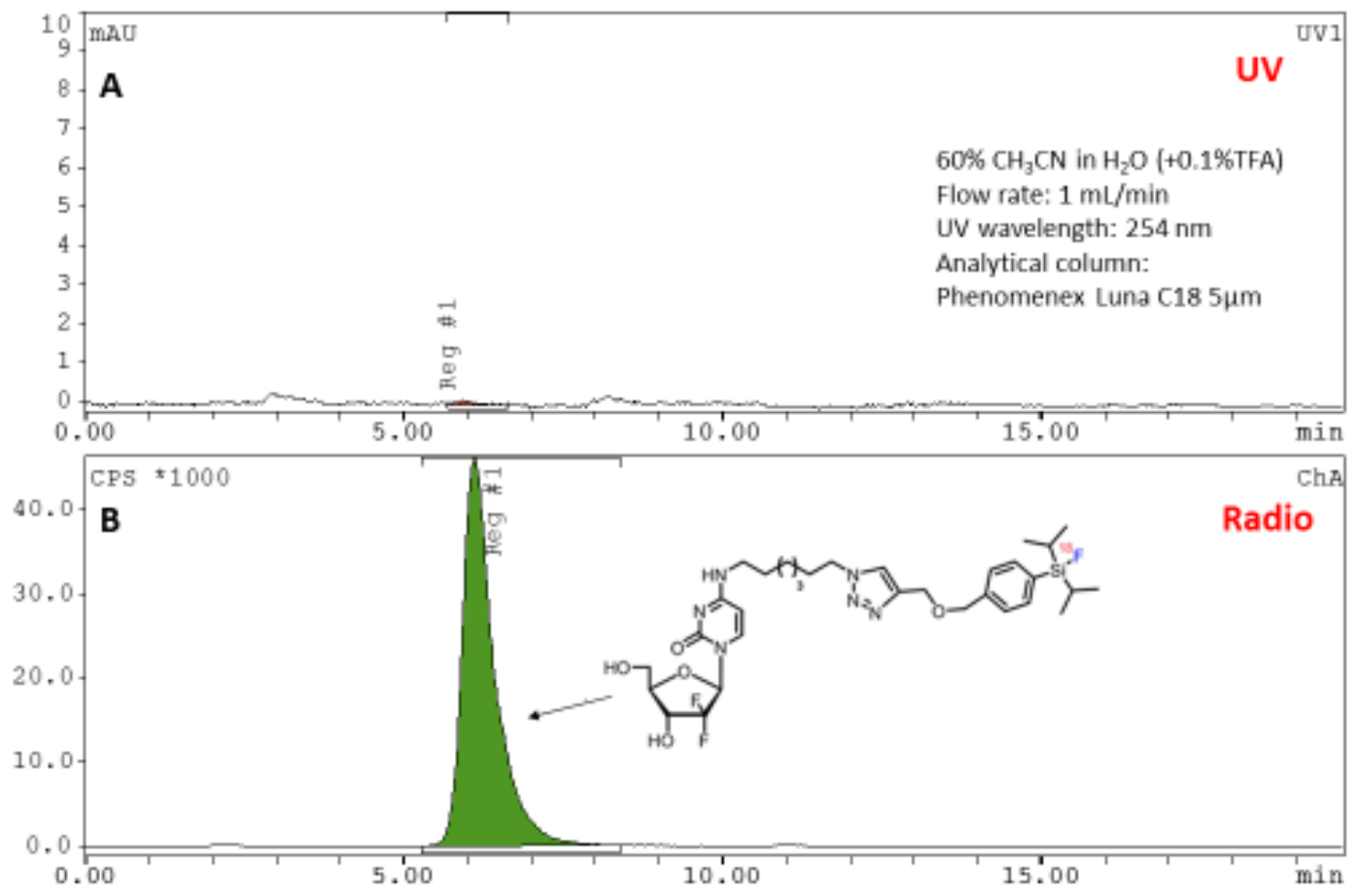

Figure 31. Macroscale radiosynthesis of $4-N$-alkyl $\left[{ }^{18} \mathrm{~F}\right] 96$ (chromatogram $A: U V$ detector, chromatogram B: gamma detector, radiolabeled product in green) in $60 \% \mathrm{CH}_{3} \mathrm{CN} / \mathrm{H}_{2} \mathrm{O}$ 


\section{Microscale radiosyntheses of 4- $N$-alkanoyl $\left[{ }^{18} \mathrm{~F}\right] 94$ and $4-N$-alkyl $\left[{ }^{18} \mathrm{~F}\right] 96$}

The microscale synthesis of $\left[{ }^{18} \mathrm{~F}\right] \mathbf{9 4}$ and 96 was performed in microdroplets on simple microfluidic chips. ${ }^{138,139}$ By adding silane precursor 90 or 92 in DMSO with $1 \%$ v/v AcOH to the previously dried $\left[{ }^{18} \mathrm{~F}\right] \mathrm{KF} / \mathrm{K}_{222}$ residue on one chip, covering with a second chip, and heating at $100^{\circ} \mathrm{C}$ for $20 \mathrm{~min}$, a decay-corrected crude radiochemical yield(without purification) for $4-N$-alkanoyl $\left[{ }^{18} \mathrm{~F}\right] \mathbf{9 4}$ was $10 \%(\mathrm{n}=1)$ (Figure 32$)$ and for $4-N$-alkyl $\left[{ }^{18} \mathrm{~F}\right] 96$ was $24.4 \pm 4.1 \%(\mathrm{n}=5)$ (Figure 33; for more detailed protocol see experimental section).

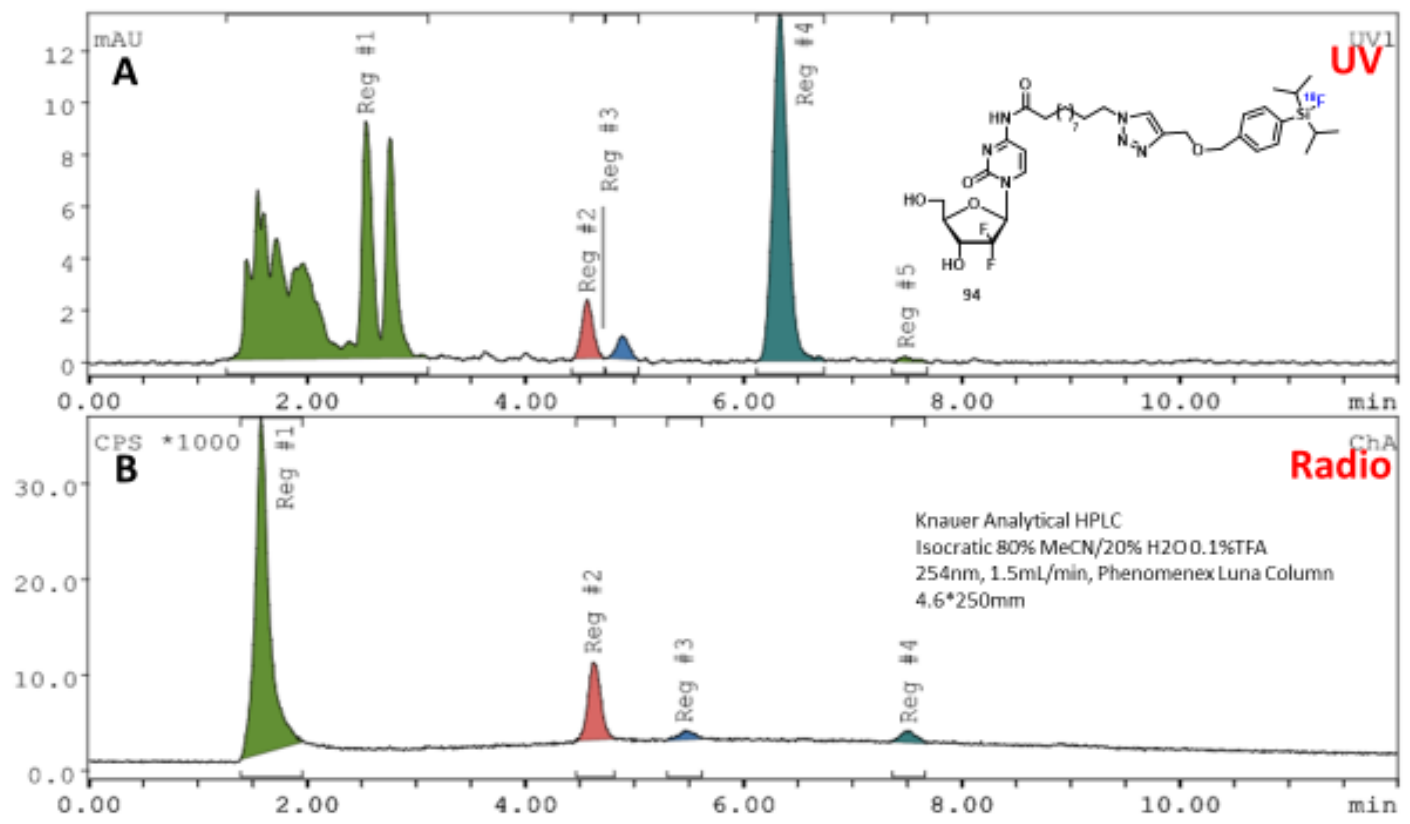

Figure 32. Microscale radiosynthesis of 4- $N$-alkanoyl $\left[{ }^{18} \mathrm{~F}\right] \mathbf{9 4}$ (chromatogram A: $U V$ detector, chromatogram B: gamma detector, radiolabeled product in red) in $80 \%$ $\mathrm{CH}_{3} \mathrm{CN} / 0.1 \%$ TFA 

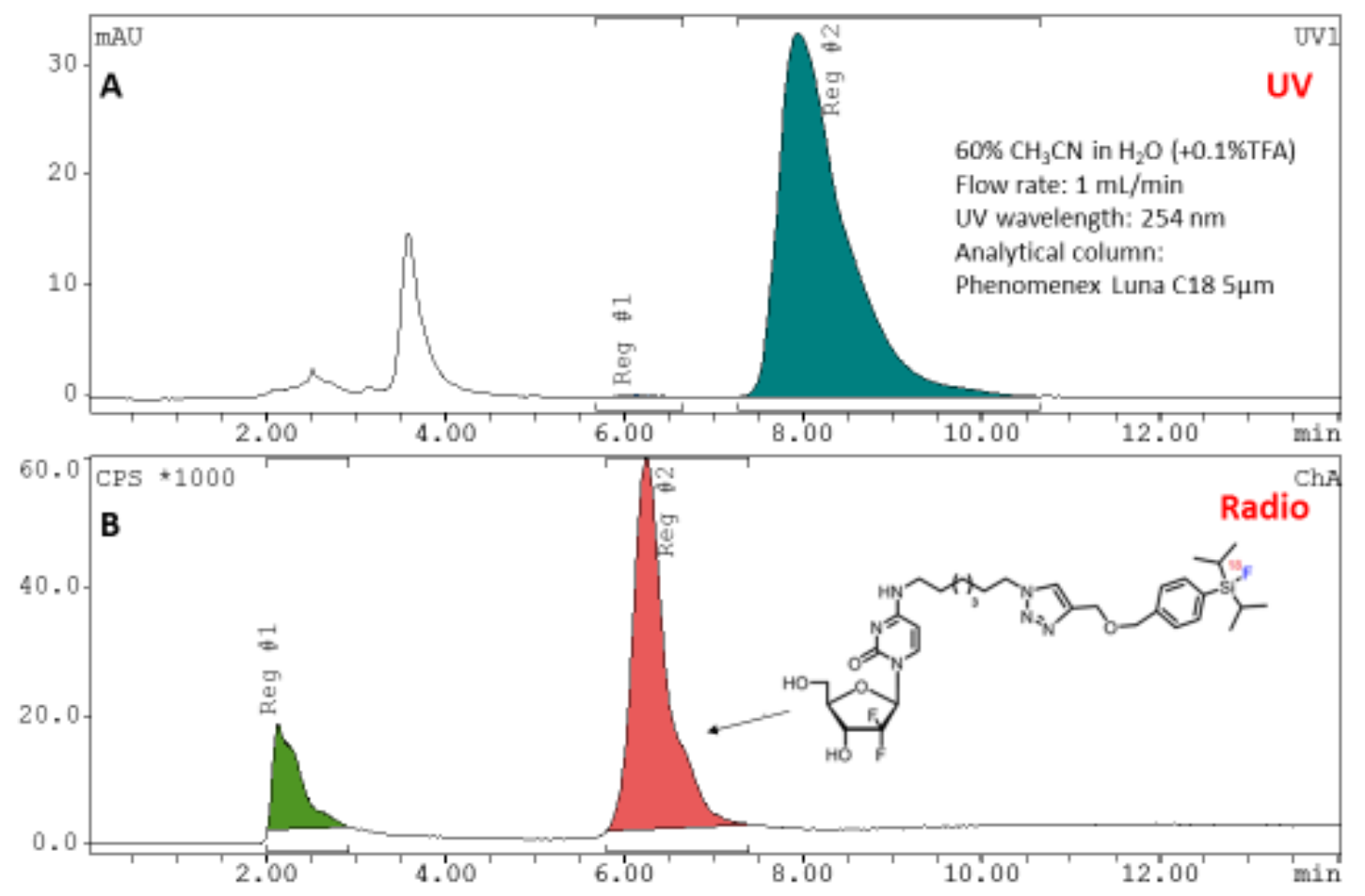

Figure 33. Microscale radiosynthesis of $4-N$-alkyl $\left[{ }^{18} \mathrm{~F}\right] 96$ (chromatogram A: UV detector, chromatogram B: gamma detector) in $70 \% \mathrm{CH}_{3} \mathrm{CN} / \mathrm{H}_{2} \mathrm{O}$

\subsubsection{Biological and PET evaluation of $\left[{ }^{18} \mathrm{~F}\right]-4-N$-alkyl gemcitabine radioligand 96}

In continuing collaboration with Dr. Michael van Dam from the Crump Institute for Molecular Imaging, a series of preliminary biological evaluations were performed with $\left[{ }^{18} \mathrm{~F}\right]-4-N$-alkyl gemcitabine radioligand 96. These studies included formulationstability analysis, in vivo imaging and metabolite analysis.

\section{Saline Formulation stability studies of $\left[{ }^{18} \mathrm{~F}\right]-4-N$-alkyl gemcitabine radioligand 96}

In order to understand the stability of radioligand $\mathbf{9 6}$, the radioligand was dissolved in saline solution and passed through a sterilization filter to obtain its final formulation. The sample was then analyzed via radio-HPLC in $1 \mathrm{~h}$ intervals for a total of $4 \mathrm{~h}$. The majority of the tracer remains intact $(100 \%$ to $\sim 90 \%$, purity $>95 \%)$ for at least $4 \mathrm{~h}(\mathrm{n}=2)$. More 
studies need to be performed in order to have a real conclusion of the stability of radioligand 96.

\section{In vivo imaging of $\left[{ }^{18} \mathrm{~F}\right]-4-N$-alkyl gemcitabine radioligand 96}

The distribution of $\left[{ }^{18} \mathrm{~F}\right] 96$ in vivo was studied using static and dynamic PET, immediately followed by computed tomography (CT) acquisition of non-tumor bearing mice (WT C57B/6). For static PET scans, a WT C57BL/6 mouse was injected with approximately $75 \mu \mathrm{Ci}\left[{ }^{18} \mathrm{~F}\right] 96$ via tail vein and imaged after $1 \mathrm{~h}$. For dynamic PET scans, dynamic microPET imaging was started concurrently at the beginning of a $10 \mathrm{sec}$ infusion via a catheter with approximately $75 \mu \mathrm{Ci}$ of $\left[{ }^{18} \mathrm{~F}\right] \mathbf{9 6}$. All images were corrected for $\mathrm{CT}$ based photon attenuation, detector normalization and radioisotope decay (scatter correction was not applied) and converted to units of percent injected dose per gram (\%ID/g).

The dynamic uptake of $\left[{ }^{18} \mathrm{~F}\right] 96$ is shown as a series of frames $(0 \mathrm{~h}$ to $1 \mathrm{~h}$; Figures 34 and 35). Figure 36 shows the time course of uptake in various organs. Note that the higher $\% \mathrm{ID} / \mathrm{g}$ in the latter figure, especially in the bladder may indicate a poor injection for the dynamic scan (i.e. much of the tracer did not get into the circulation). In the dynamic PET experiment, we observe the tracer first in the GI tract, gallbladder and liver but significant bone uptake is evident after 15-20 min post-injection (Figure 34, 35 and 36). One cause of bone uptake is defluorination of the PET tracer, releasing $\left[{ }^{18} \mathrm{~F}\right]$ fluoride, which is strongly taken up by bone. Biodistribution from the 10 min static scan (Figure 37) also shows significant bone uptake. More detailed analysis of tracer metabolites in vivo is needed to determine whether defluorination is occurring or some other effect is leading to high bone uptake. 

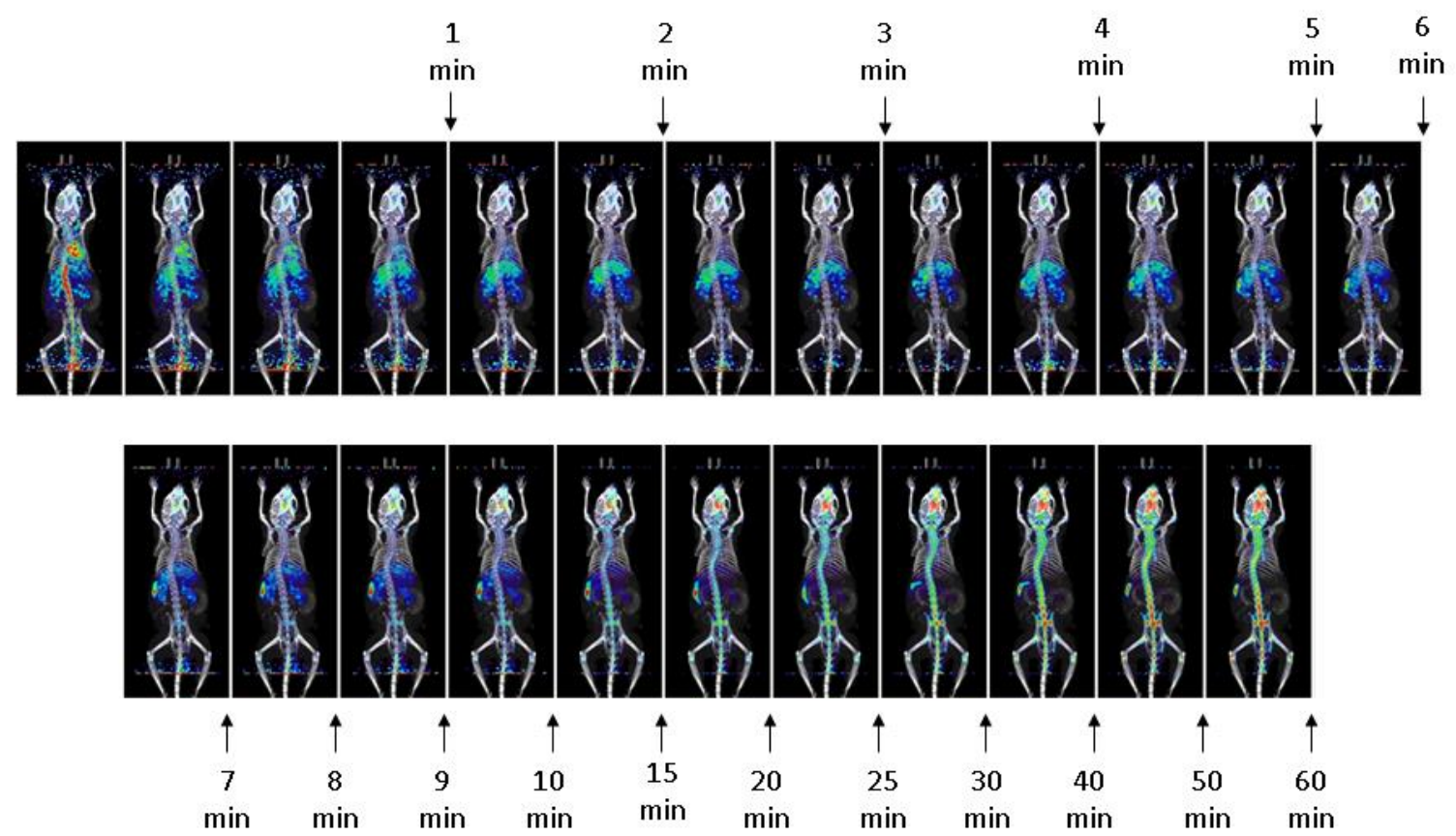

Figure 34. Series of frames from dynamic PET scan of WT C57BL/6 mouse injected with $\left[{ }^{18} \mathrm{~F}\right] 96$ (up to $1 \mathrm{~h}$ ). Images are coronal maximum intensity projections.
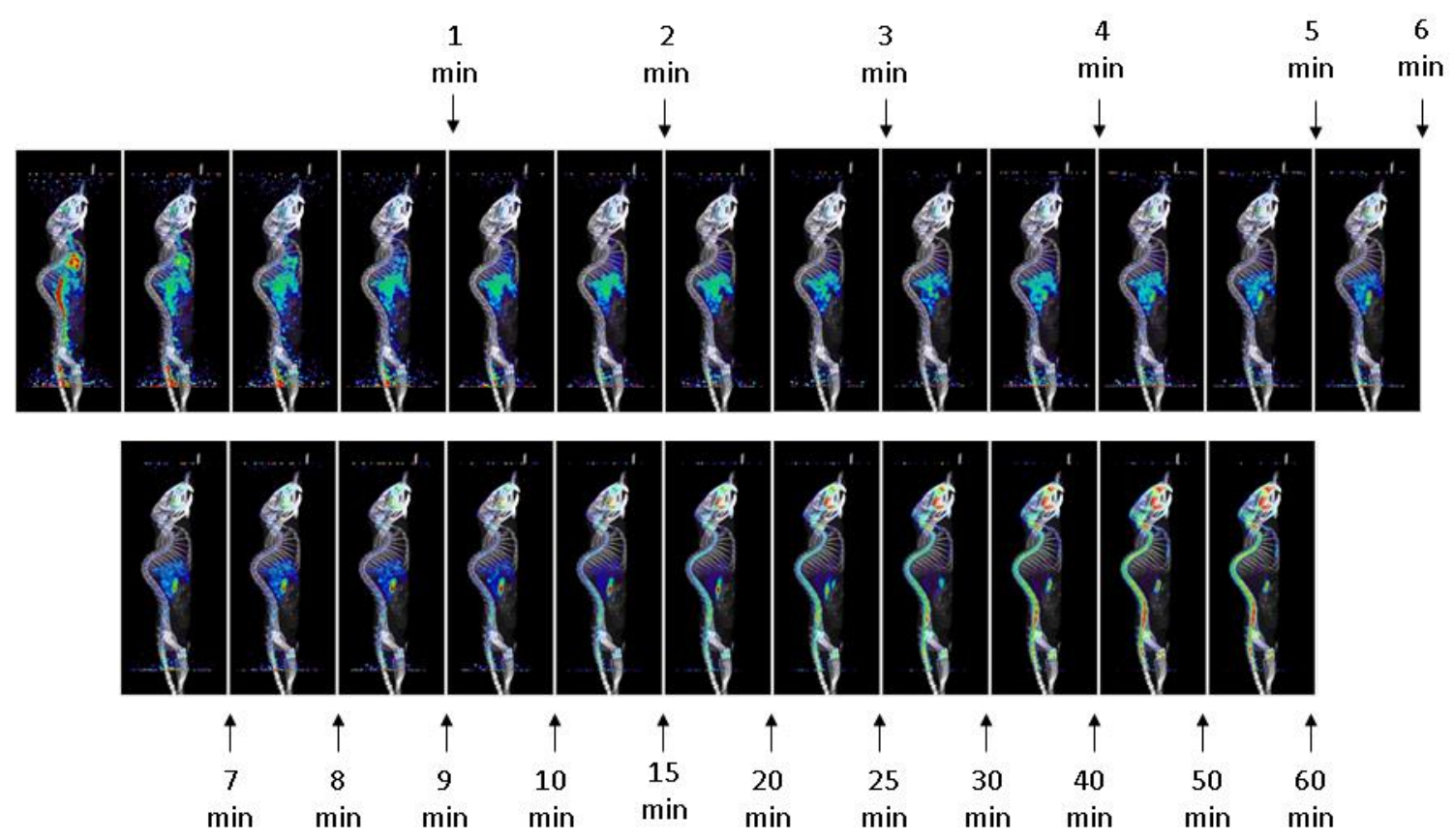

Figure 35. Series of frames from dynamic PET scan of WT C57BL/6 mouse injected with $\left[{ }^{18} \mathrm{~F}\right] 96$ (up to $1 \mathrm{~h}$ ). Images are sagittal maximum intensity projections. 

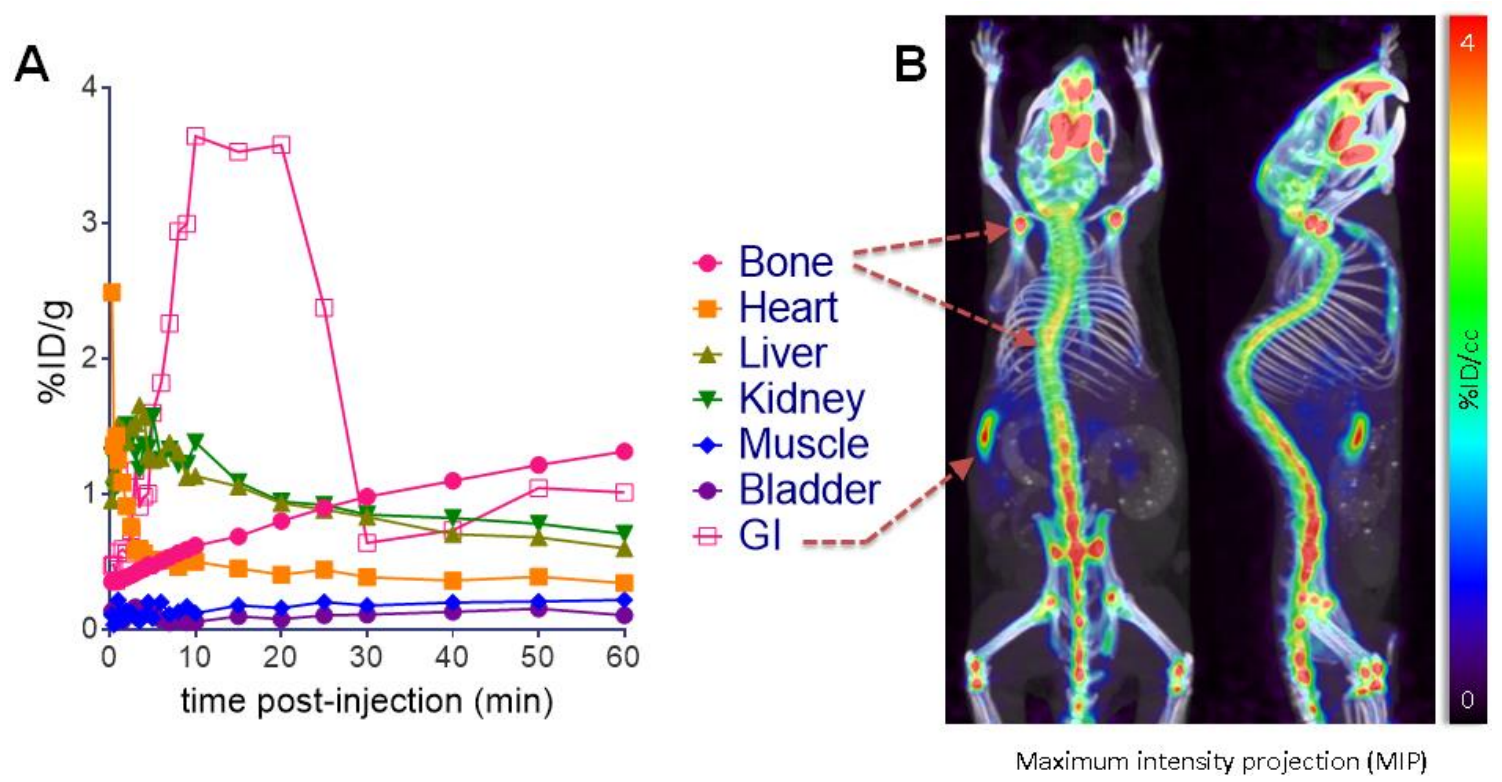

Figure 36. (Left) Dynamic biodistribution of $\left[{ }^{18} \mathrm{~F}\right] 96$ in WT C57BL/6 mouse. (Right) Maximum intensity projection at $1 \mathrm{~h}$ post-injection (left: coronal; right: sagittal).
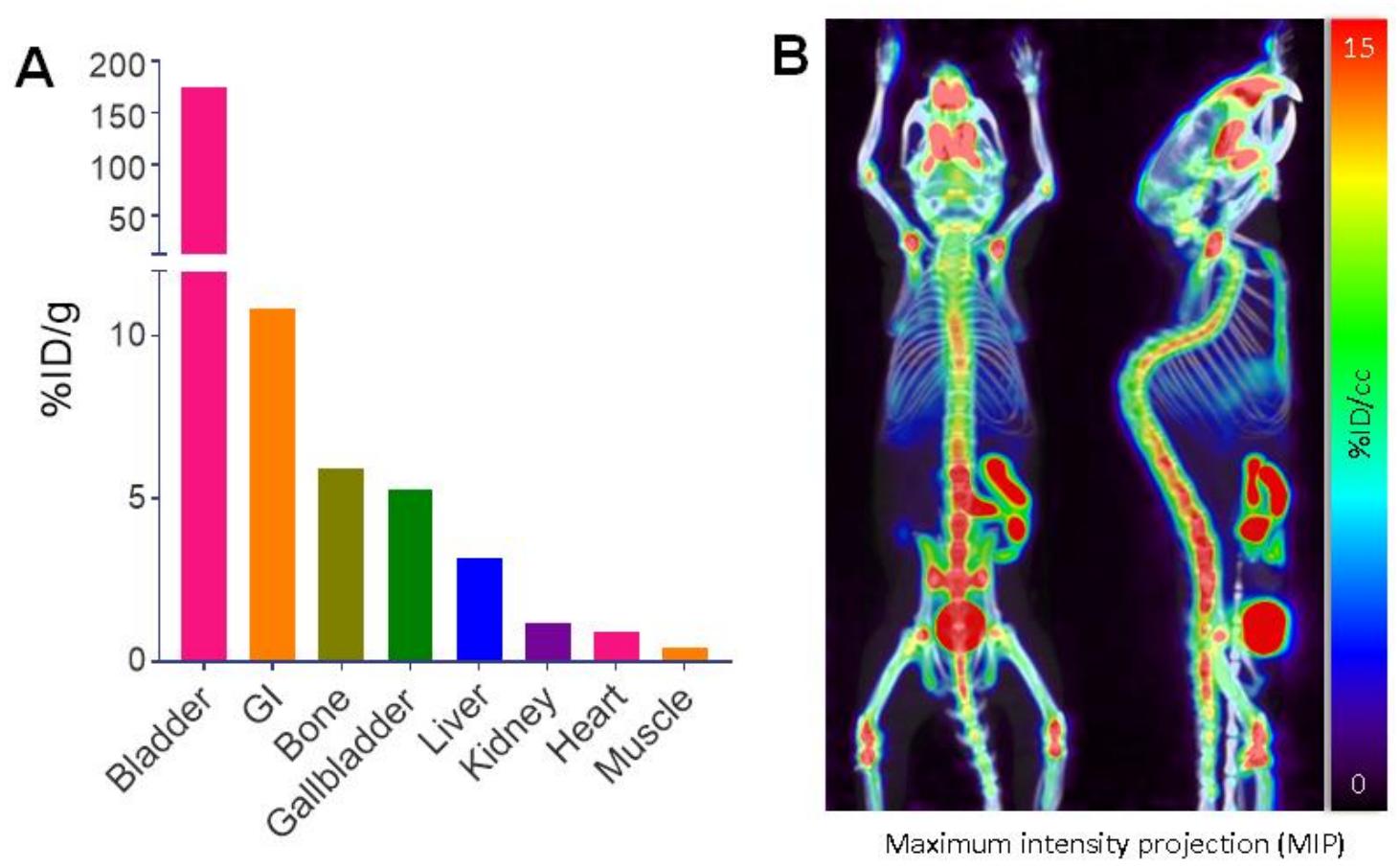

Figure 37. (Left) Biodistribution of $\left[{ }^{18} \mathrm{~F}\right] \mathbf{9 6}$ from $10 \mathrm{~min}$ static scan in WT C57BL/6 mouse at $1 \mathrm{~h}$ post-injection. (Right) Maximum intensity projection of 10 min static scan at $1 \mathrm{~h}$ post-injection (left: coronal; right: sagittal). 


\section{Metabolite analysis of $\left[{ }^{18} \mathrm{~F}\right]-4-N$-alkyl gemcitabine radioligand 96}

In order to study the uptake of radioligand $\mathbf{9 6}$ by red blood cells, ex vivo and in vivo experiments were performed with mouse blood. Ex vivo incubation of $0.5 \mathrm{mCi}$ of $\left[{ }^{18} \mathrm{~F}\right] \mathbf{9 6}$ for $30 \mathrm{~min}$ at $37^{\circ} \mathrm{C}$ shows that $2.5 \%$ of radioactivity is in the cells, while $97.5 \%$ is found in the plasma. In the in vivo experiment, a mouse was injected via tail vein with $1 \mathrm{mCi}$ of $\left[{ }^{18} \mathrm{~F}\right] 96$. After $30 \mathrm{~min}, 800 \mu \mathrm{L}$ was collected. Analysis shows $3.2 \%$ of radioactivity in the cells and $96.8 \%$ is found in the plasma. These results show that after 30 incubations, most of $\left[{ }^{18} \mathrm{~F}\right] 96$ is available to the tissues, but the samples need to be analyzed via radio-HPLC in order to check that this radioactivity is due to intact $\left[{ }^{18} \mathrm{~F}\right] \mathbf{9 6}$.

\subsection{Reduction of sugar lactones to hemiacetals using lithium triethylborohydride}

\subsubsection{Reduction with LTBH: Rationale}

The goal of this project was to explore the use of lithium triethylborohydride (LTBH) as a reducing agent for the conversion of sugar lactones to hemiacetals without the over reduction to their diol products. As it was discussed in the introduction, there are several reducing agents that have been utilized for the transformation of lactones to hemiacetals. These reducing agents range from the common $\mathrm{NaBH}_{4}$ and DIBAL-H, to more sophisticated methods such as catalytic reduction with generated in situ titanocene(III) hydride. ${ }^{121,}{ }^{122}$ Although the application of LTBH in organic synthesis is well documented, ${ }^{140-143}$ including the reduction of lactams to cyclic hemiaminals (azahemiacetals), including in sugar lactams, ${ }^{110}$ the reduction of lactones to the lactols with LTBH is underdeveloped. In the synthesis of 4-C-alkyl/aryl-substituted $S$ ribosylhomocysteine (SRH) analogues, ${ }^{112}$ which were prepared by coupling of homocysteine with 4-substituted ribonolactone derivatives, a project that I was involved 
in, LTBH was used to reduce a series 4-C-alkyl/aryl-modified lactones to their corresponding hemiacetals (Scheme 27). These hemiacetals were then coupled to homocysteine to yield 4C-SRH analogues.
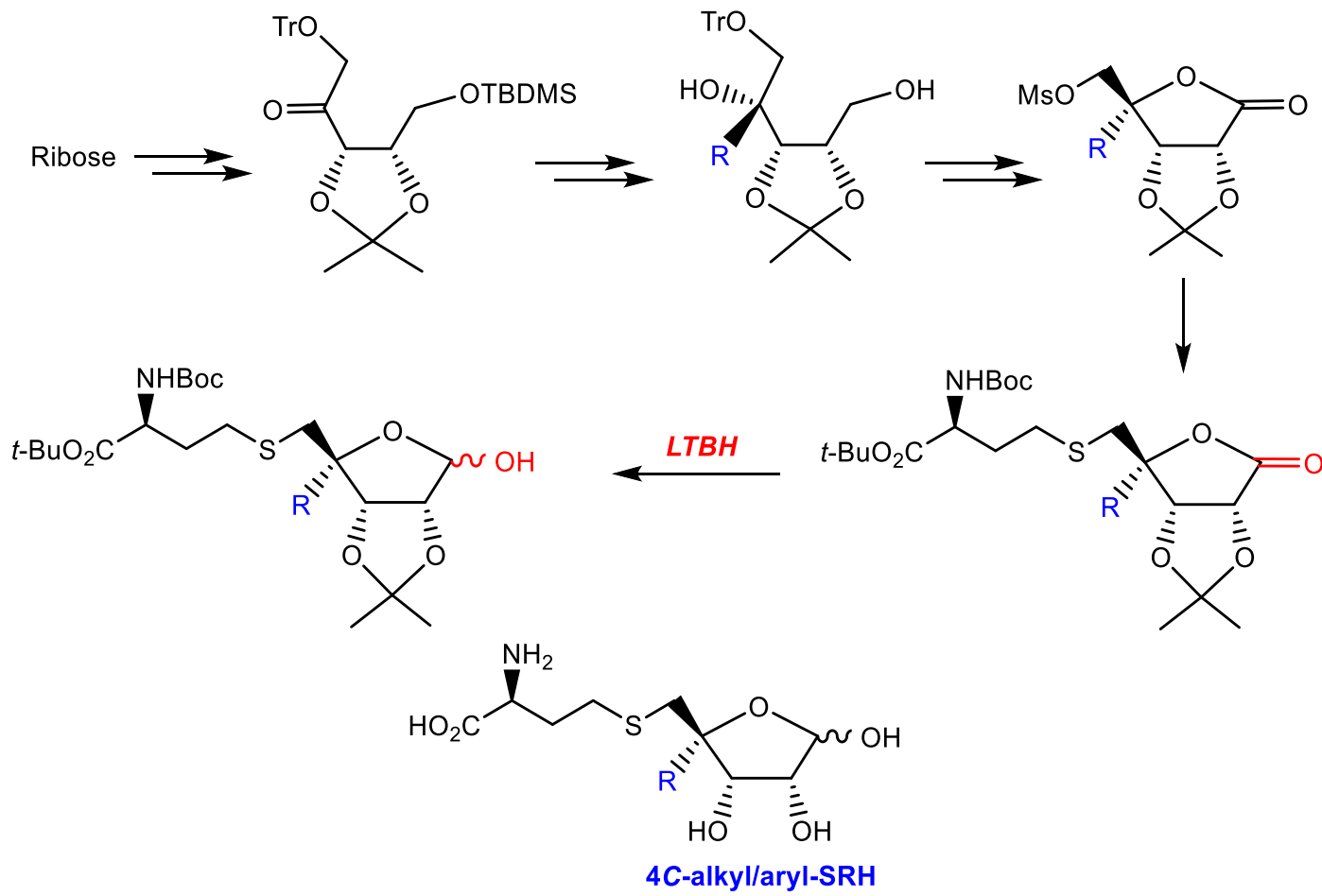

Scheme 27. Synthesis of 4C-SRH analogues involving reduction of ribonolactones with $\mathrm{LTBH}^{112}$

In a series of selective reduction papers from 1980, Brown reported that LTBH, when used in excess (2 equiv.), efficiently reduced esters to alcohols and lactones ( $\gamma$ butyrolactone) to diols. ${ }^{144}$ This protocol has been extensively used in organic synthesis, but reduction to hemiacetals has not been explored. This lead to this intensive study on LTBH to better understand its use for sugar lactones.

\subsubsection{Reduction optimization and study of parameters}

Initially, I wanted to test the reduction of lactones to hemiacetals with LTBH with a readily available sugar lactone. We chose 5-O-benzyl-2,3-O-isopropylidene-D-ribono-1,4- 
lactone 97 (Scheme 28). In a previous project done by our group, reduction of protected sugar lactams was done with $\mathrm{CH}_{2} \mathrm{Cl}_{2}$ at $0{ }^{\circ} \mathrm{C}$ in 30 min- $1 \mathrm{~h}$. Because of this, we decided to start with similar conditions.

Thus, treatment of 97 with 1.0 equiv. or 1.1 equiv. of $\mathrm{LTBH}\left(\mathrm{CH}_{2} \mathrm{Cl}_{2} / 0{ }^{\circ} \mathrm{C} / 30 \mathrm{~min}\right)$ showed about $90-95 \%$ conversion to the ribofuranose $\mathbf{9 8}$ with $\sim 5-10 \%$ of substrate $\mathbf{9 7}$ remaining unchanged ( ${ }^{1} \mathrm{H}$ NMR; Table 7, entries 1 and 2). However, treatment of 97 with 1.2 equiv. of LTBH gave a complete conversion to hemiacetal $98(\alpha / \beta, 1: 4)$ after $30 \mathrm{~min}$ without noticeable detection of the peaks for the lactone 97 and diol 99 on the ${ }^{1} \mathrm{H}$ NMR spectra of the crude reaction mixture (entry 3). Effect of different ratios of LTBH to lactone 97 as well as temperature, reaction time and solvent are summarized in Table 7.

Briefly, increasing the ratio of LTBH to 1.5 equiv. still gives hemiacetal 98 as a single product (entry 4). However, the increase to 2.5 equiv. of LTBH led to substantial formation of diol 99 (entry 5). Yet, even when the reduction was carried out for longer time (up to 22 h) hemiacetal 98 was still isolated although in lower yields. Interestingly, temperature did not have a significant effect on the reduction of lactone $\mathbf{9 8}$ to hemiacetal 99 and similar results were obtained at $-78{ }^{\circ} \mathrm{C}, 0^{\circ} \mathrm{C}$, or r.t. (entries 4,6 and 7). Additionally, reduction of 97 in toluene or chloroform did not affect the reduction (entries 8 and 9) but interestingly, reduction in THF gave substantially lower yield (entry 10).
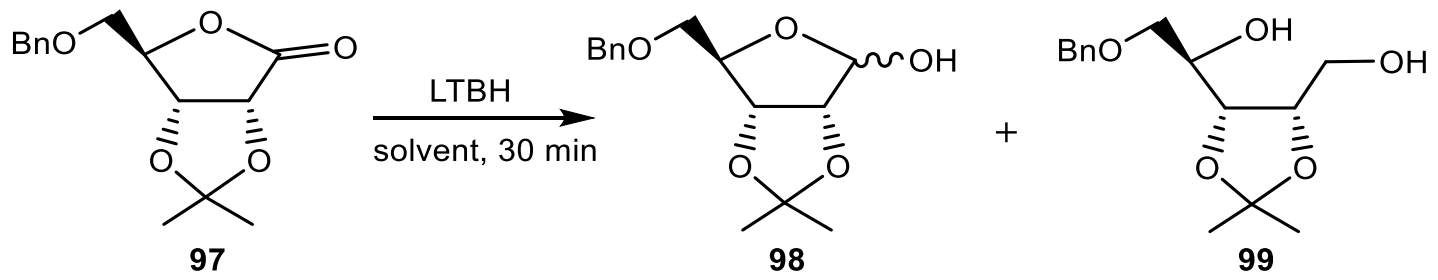

Scheme 28. Reduction of the protected ribono-1,4-lactone 97 with LTBH 
Table 7. Effect of various reaction parameters on reduction of 97 with $\mathrm{LTBH}^{a}$

\begin{tabular}{ccccccc}
\hline Entry & Solvent & $\begin{array}{c}\text { LTBH } \\
\text { (equiv.) }\end{array}$ & $\begin{array}{c}\text { Temperature } \\
\left({ }^{\circ} \mathbf{C}\right)\end{array}$ & $\begin{array}{c}\text { Yield }^{b} \text { 98 } \\
(\%)\end{array}$ & $\begin{array}{c}\text { Yield }^{b} \\
\mathbf{9 9}(\%)\end{array}$ & $\begin{array}{c}\text { Ratio }^{b} \\
\text { 97:98:99 }\end{array}$ \\
\hline $\mathbf{1}$ & $\mathrm{CH}_{2} \mathrm{Cl}_{2}$ & 1.0 & 0 & 90 & - & $1: 9: 0$ \\
$\mathbf{2}$ & $\mathrm{CH}_{2} \mathrm{Cl}_{2}$ & 1.1 & 0 & 95 & - & $1: 19: 0$ \\
$\mathbf{3}$ & $\mathrm{CH}_{2} \mathrm{Cl}_{2}$ & 1.2 & 0 & $99(95)^{c}$ & - & $0: 1: 0$ \\
$\mathbf{4}$ & $\mathrm{CH}_{2} \mathrm{Cl}_{2}$ & 1.5 & 0 & 99 & - & $0: 1: 0$ \\
$\mathbf{5}$ & $\mathrm{CH}_{2} \mathrm{Cl}_{2}$ & 2.5 & 0 & $40(34)^{c}$ & $60(55)^{c}$ & $0: 4: 6$ \\
$\mathbf{6}$ & $\mathrm{CH}_{2} \mathrm{Cl}_{2}$ & 1.5 & 20 & 94 & - & $0: 1: 0$ \\
$\mathbf{7}$ & $\mathrm{CH}_{2} \mathrm{Cl}_{2}$ & 1.5 & -78 & 95 & - & $0: 1: 0$ \\
$\mathbf{8}$ & $\mathrm{Toluene}^{c}$ & 1.5 & 0 & 93 & - & $0: 1: 0$ \\
$\mathbf{9}$ & $\mathrm{CHCl}_{3}$ & 1.5 & 0 & 95 & - & $1: 19: 0$ \\
$\mathbf{1 0}$ & $\mathrm{THF}$ & 1.5 & 0 & 30 & - & $7: 3: 0$ \\
\hline
\end{tabular}

${ }^{a}$ Reduction was performed on 0.15 mmol scale of 97 with $1 \mathrm{M}$ solution of LTBH in THF. ${ }^{b}$ Determined by ${ }^{1} \mathrm{H}$ NMR of the crude reaction mixture.

${ }^{c}$ Isolated yield.

\subsubsection{Reaction profile of reduction of lactone 97 to hemiacetal 98}

The reaction profile for the conversion of lactone 97 to hemiacetal 98 and diol 99, was studied using ${ }^{1} \mathrm{H}$ NMR using 1.2 equiv. and 2.5 equiv. of LTBH. In both cases (1.2 and 2.5 equiv.), complete conversion of lactone $\mathbf{9 7}$ to lactol $\mathbf{9 8}$ was observed in less than 5 min, making it important to further investigate how quickly the reaction actually is and how it is affected by time. 


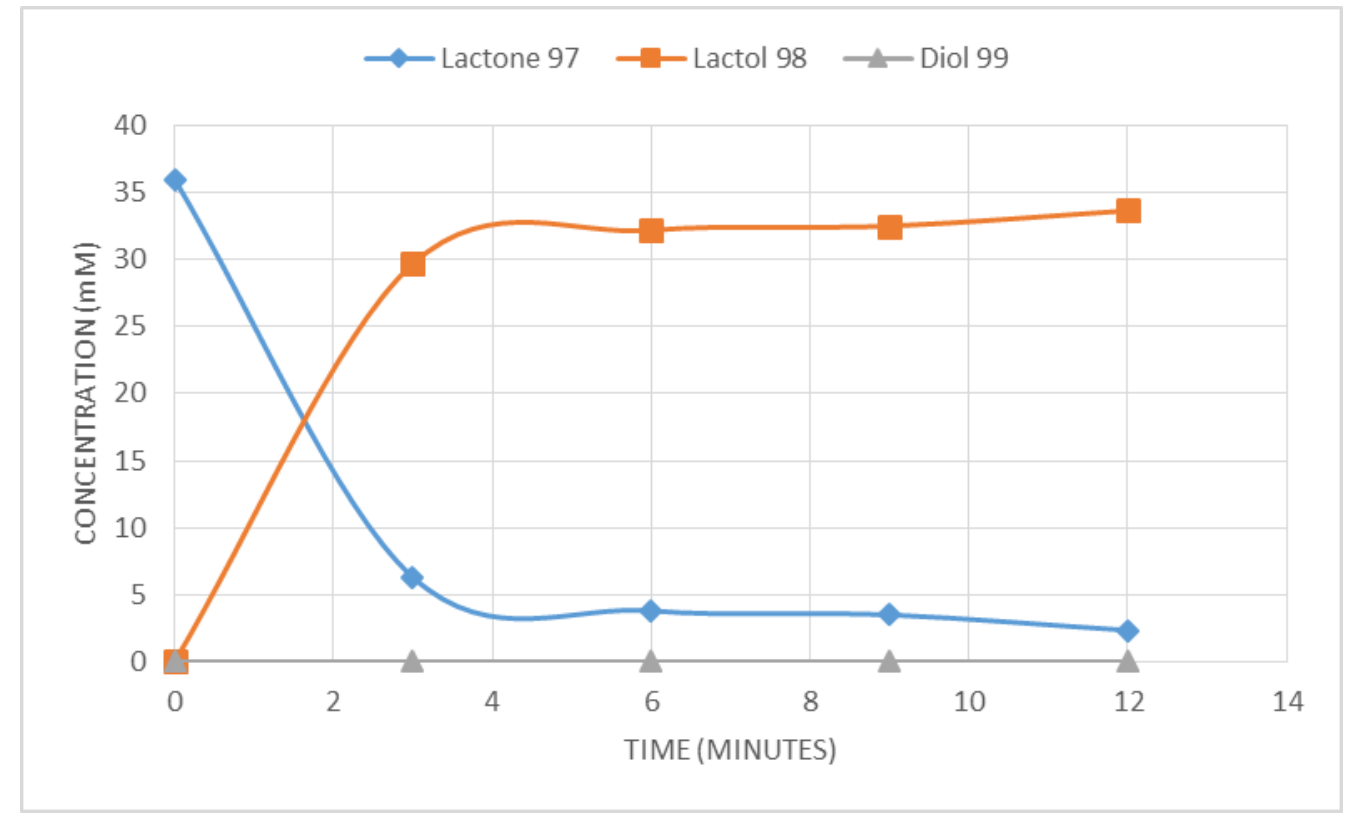

Figure 38. Reduction of lactone $97(36 \mathrm{mM})$ with 1.2 equiv. of $\mathrm{LTBH}\left(0{ }^{\circ} \mathrm{C} / \mathrm{CH}_{2} \mathrm{Cl}_{2}\right)$. The profile for the reactions was measured by integrating the peaks of the ${ }^{1} \mathrm{H}$ NMR spectra (e.g., disappearance of the $\mathrm{H} 4$ peak at $4.65 \mathrm{ppm}$ for $\mathbf{9 8}$ and appearance of the $\mathrm{H} 1$ peak at 5.28 ppm for 99 ).

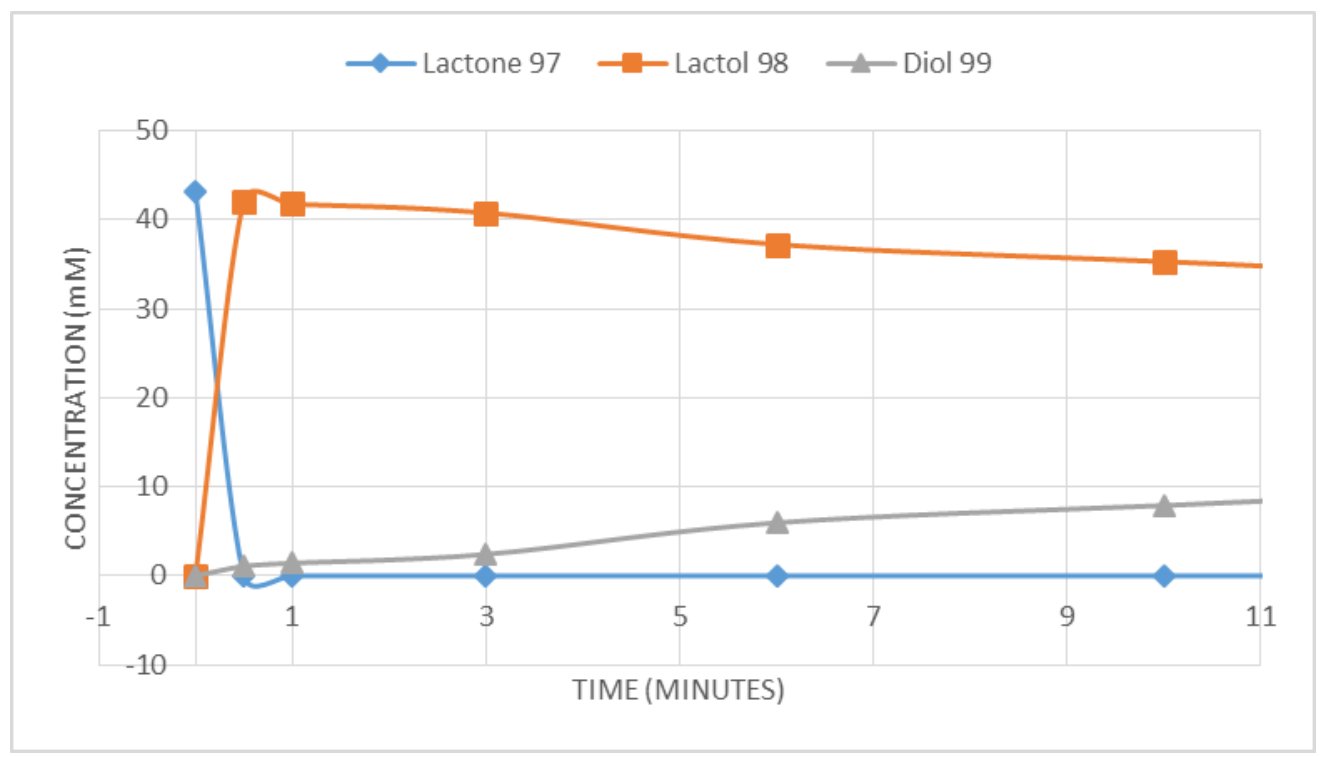

Figure 39. Reduction of lactone $97(42 \mathrm{mM})$ with 2.5 equiv. of LTBH $\left(0{ }^{\circ} \mathrm{C}^{\circ} \mathrm{CH}_{2} \mathrm{Cl}_{2}\right)$. The profile for the reactions was measured by integrating the corresponding peaks of the ${ }^{1} \mathrm{H}$ NMR spectra (e.g., disappearance of the H4 peak at $4.65 \mathrm{ppm}$ for 97 and appearance/disappearance of the $\mathrm{H} 1$ peak at $5.28 \mathrm{ppm}$ for $\mathbf{9 8}$ and appearance of the $\mathrm{H} 3$ peak at $4.10 \mathrm{ppm}$ for 99). 
It is important to also note that in the reaction with 1.2 equiv. of LTBH no diol 99 was ever detected. Reduction of $\mathbf{9 7}$ with 2.5 equiv. of LTBH was completed within 1 min showing exclusive formation of lactol $\mathbf{9 8}$. Interestingly, longer reaction time showed a slow disappearance of lactol $\mathbf{1 3 3}$ with increasing formation of diol byproduct $\mathbf{9 9}$ [0.5 h, $\mathbf{9 8}$ (72\%)/99 (28\%); 2 h, $98(65 \%) / 99(35 \%)$, see ${ }^{1} \mathrm{H}$ NMR reaction profile in experimental section 4.6.1., which was also observed in our preliminary reaction parameters. Using 1.2 equiv. of LTBH leads to no diol formation, even if left reacting for long periods of time and at room temperature, but when excess of LTBH is used, such as 2.5 equiv., diol formation requires longer time, making the conditions optimal for fast reaction time.

\subsubsection{Reduction of several sugar lactones}

To probe the generality of the reduction of sugar lactones to the corresponding hemiacetals with LTBH, several $\gamma$ - and $\delta$-lactones were tested (Table 8). Thus, reduction of 2,3-O-isopropylidene-ribono-1,4-lactones with trityl (100), benzoyl (102) or acetyl (104) protection at 5-hydroxyl provided the corresponding lactols 101, 103, and 105 (entries 2-4). The trityl and benzoyl protection groups were found to be stable under these reducing conditions. Reduction of the 5'-O-acetyl lactone $\mathbf{1 0 4}$ yielded also substantial amount of 2,3-O-isopropylidene- $\alpha / \beta$-D-ribofuranose after $30 \mathrm{~min}$ as a result of the reduction of the acetyl ester. However, reduction with 1.1 equiv. of LTBH and shorter reaction time (10 min) provided lactol 105 in 70\% yield (entry 4). Reduction of 2,3,5-tri$O$-acetyl lactone $\mathbf{1 0 6}$ gave hemiacetal $\mathbf{1 0 7}$ but in low yield (30\%, entry 5), again, due to the reductions of the acetyl esters. Conversion of 2,3-O-isopropylideneribono-1,4-lactone 108 to ribose 109 required an increased amount of LTBH (1.6 equiv.; entry 6). Reduction of the 3,5-O-TBDMS-2-deoxy-D-ribono-1,4-lactone $\mathbf{1 1 0}$ also proceeded efficiently to give 
the 2-deoxyribose product 111 when 1.5 equiv. of LTBH was used (entry 7). However, reduction of 5-O-TBDMS-2,3-dideoxy-D-ribono-1,4-lactone 112 yielded both the 2,3dideoxyribose 113 and the corresponding diol byproduct (entry 8). Moreover, reduction of D-ribono-1,5-lactone 114 efficiently produced the corresponding ribopyranose derivative 115 in $88 \%$ yield (entry 9).

The lactones derived from hexoses were also efficiently reduced with LTBH to the corresponding hemiacetals. Thus, reduction of 2,3:5,6-Di- $O$-isopropylidene-D-gulono1,4-lactone 116 gave gulonofuranose 117 (91\%, entry 10). Treatment of trimethylsilyl protected glucono-1,5-lactones 118 with LTBH yielded glucopyranose $119(\alpha / \beta, 2: 1$; entry 11). Analogous reduction of the fully acetylated D-glucono-1,5-lactone $\mathbf{1 2 0}$ provided glucose 121 in low yield due to concomitant reduction of the ester protecting group (entry 12). Attempted reduction of the fully benzoylated glucono-1,5-lactone gave similar results (entry 12). However, reduction of glucono-1,5-lactone $\mathbf{1 2 2}$ bearing benzylidene and tertbutyldimethylsilyl protection groups proceeded efficiently to give lactol $\mathbf{1 2 3}$ in $80 \%$ yield (entry 13). Hence, reduction of sugar lactones with LTBH to lactols appears to have a general character and is clearly compatible with acid-, base- and fluoride-labile protecting groups commonly used in carbohydrate chemistry.

Table 8. Reduction of various sugar lactones with LTBH to lactols ${ }^{a}$
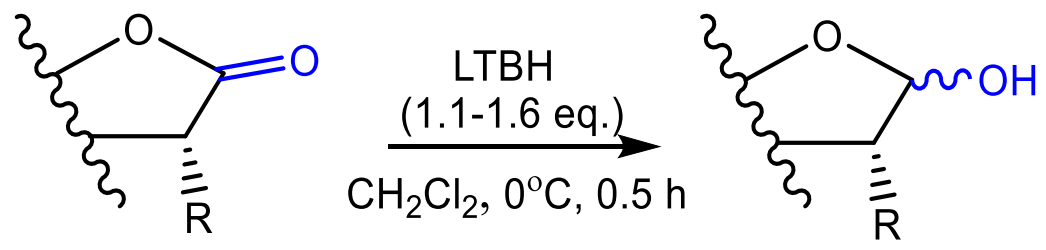


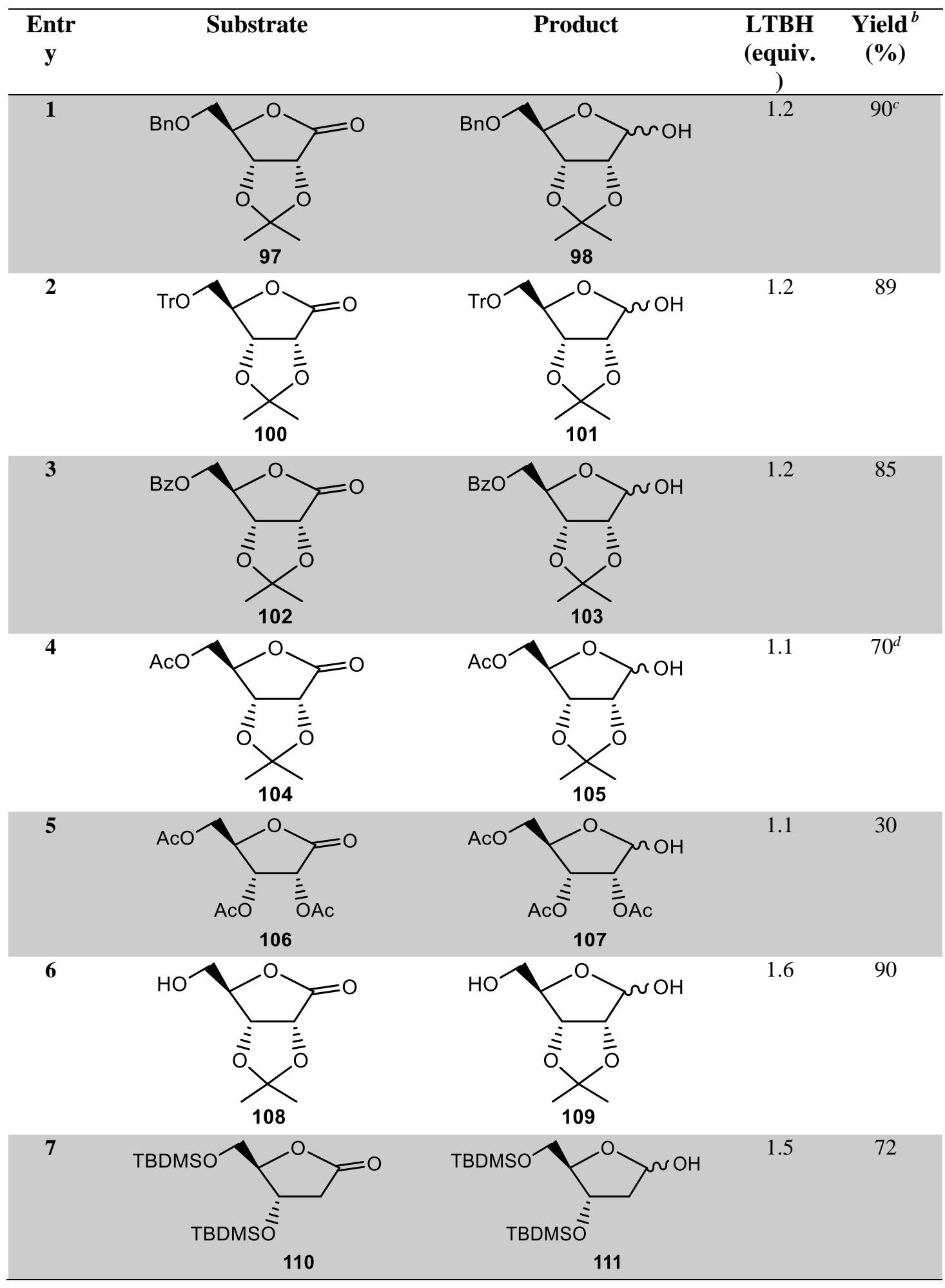




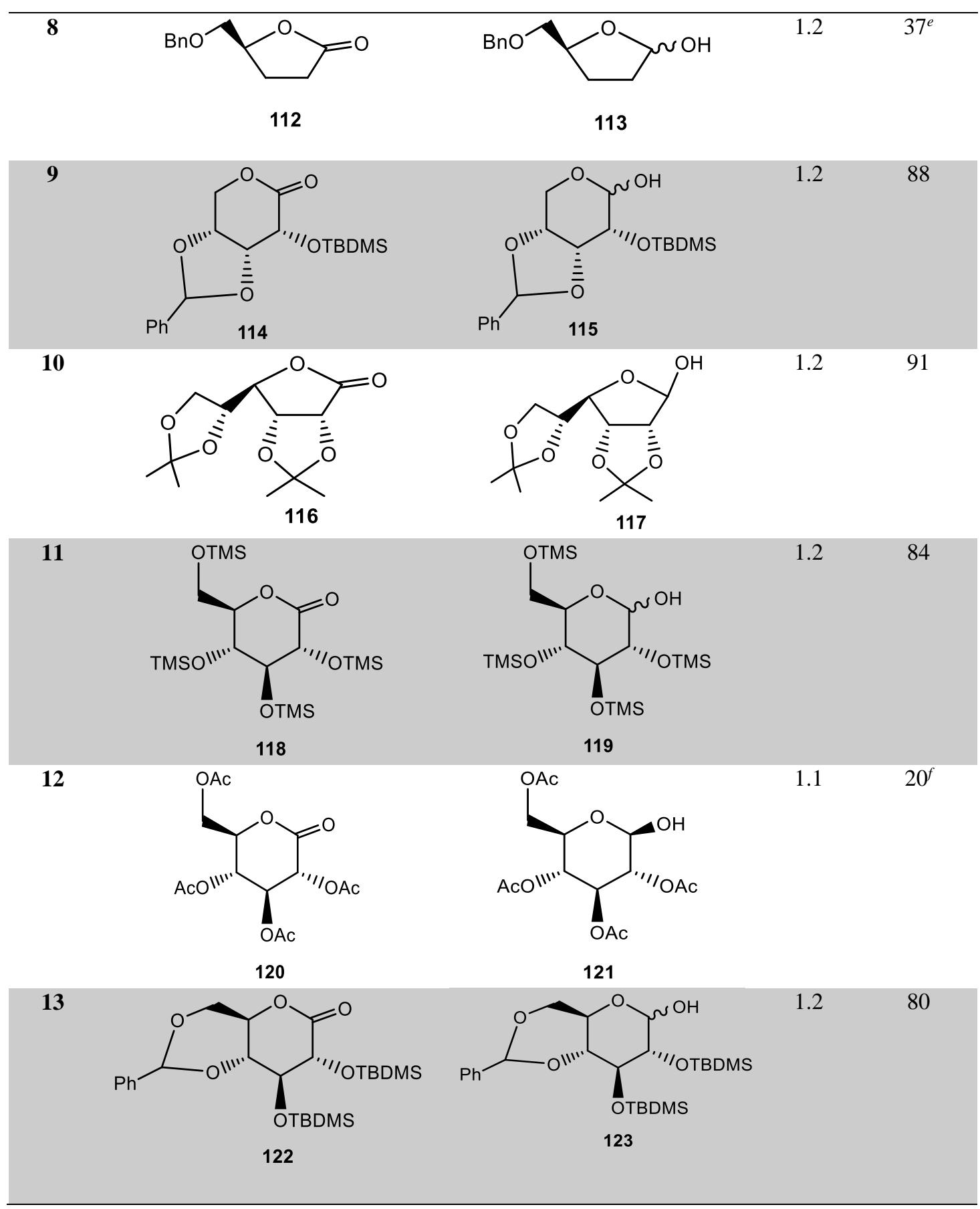

${ }^{a}$ Reduction was performed on $0.1-1.0 \mathrm{mmol}$ scale of lactones with $1 \mathrm{M}$ solution of LTBH/THF.

${ }^{b}$ Isolated yield as a mixture of $\alpha / \beta$ anomers.

${ }^{c}$ Reduction on $1.0 \mathrm{mmol}$ scale.

${ }^{d}$ With 1.2 equiv. of LTBH the 2,3- $O$-isopropylidene- $\alpha / \beta$-D-ribofuranose was isolated in $37 \%$ yield.

${ }^{e}(R)$-5-(benzyloxy)pentane-1,4-diol (42\%) and the residual amount of unchanged $112(\sim 5 \%)$ was also isolated.

${ }^{f}$ Analogous reduction of 2,3,4,6-tetra- $O$-benzoylglucono-1,5-lactone ${ }^{145}$ yielded 2,3,4,6-tetra- $O$ benzoylglucopyranose ( 15-20\%; TLC, ${ }^{1} \mathrm{H}$ NMR). 
Reduction of some sugar lactones was also performed with $\mathrm{NaBH}_{4}$ and DIBAL-H in order to compare our LTBH protocol with these commonly used reducing agents. Thus, reduction of $\mathbf{1 0 0}$ or 110 with $\mathrm{NaBH}_{4}(1.1$ equiv. $)$ in $\mathrm{EtOH}\left(0{ }^{\circ} \mathrm{C}\right)$ after 30 min showed only a small conversion to the lactol products 101 and $111(\sim 5-10 \%)$ with the unchanged lactones $(\sim 80 \%)$ and the corresponding diols ( 5-10\%) present (TLC, ${ }^{1} \mathrm{H}$ NMR). Increasing the amount of $\mathrm{NaBH}_{4}$ (5 equiv.) resulted in the formation of the corresponding diols as the major product ( 70\%). Reduction of 110 with DIBAL-H in $\mathrm{CH}_{2} \mathrm{Cl}_{2}\left(-78{ }^{\circ} \mathrm{C}\right.$, 30 min.) yielded lactol $111(90 \%)$. However, analogous treatment of 5-O-acetyl lactone 104 with DIBAL-H yielded mixture $(\sim 2: 3)$ of desired lactol 105 and the lactol 109 as a result of the concomitant reduction of the acetyl ester.

Reduction of $\gamma$-butyrolactone 124 with $\mathrm{LTBH}$ (1.8 equiv. $/ \mathrm{CH}_{2} \mathrm{Cl}_{2} / 0{ }^{\circ} \mathrm{C}$; Method $\mathrm{A}$, Scheme 29] gave 1,4-butanediol 125 as the sole product. Various modifications of the reduction protocol [LTBH (0.5-1.2 equiv.) $/ \mathrm{CH}_{2} \mathrm{Cl}_{2} /-78{ }^{\circ} \mathrm{C}$ or $0{ }^{\circ} \mathrm{C}$ or r.t./30 $\min$ to $2 \mathrm{~h}$ ] produced diol 125 in addition to different quantities of the unchanged lactone 124, but the corresponding lactol was not observed. This is in agreement with the results reported by Brown that reduction of $\mathbf{1 2 4}$ with LTBH (2.0 equiv.; THF/-78 ${ }^{\circ} \mathrm{C}$; Method B) gave 125 in $94 \% .^{144}$

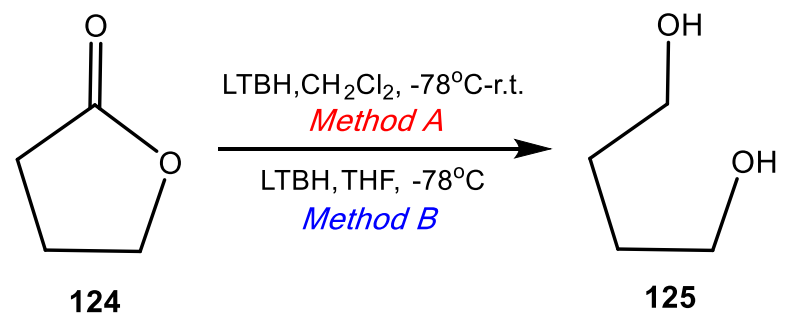

Scheme 29. Reduction of $\gamma$-butyrolactone with LTBH to 1,4-butanediol 
Typically, the reduction of the tested sugar lactones with $\mathrm{LTBH}$ in $\mathrm{CH}_{2} \mathrm{Cl}_{2}$ is higher yielding when the lactone had a larger number of hydroxyl groups (e.g., ribonolactone > 2-deoxyribonolactone $>$ 2,3-dideoxyribonolactone). The fact that reduction of 2,3dideoxyribonolactone with LTBH can be controlled to give the lactol product, while under similar conditions $\gamma$-butyrolactone is converted to the diol provides support for the assumption that chelation of the borane reagent to the exocyclic sugar hydroxyl group (oxygen) is critical in this reduction process (Figure 40). Buchwald invoked coordination of the titanium center to the lactone's oxygen atoms during reduction of lactones to lactols with titanocene(III) hydrides. ${ }^{121}$ The fact that reduction with LTBH gave much better yields in $\mathrm{CH}_{2} \mathrm{Cl}_{2}$ than in THF (Table 7) may be attributed to the additional coordination of LTBH reagent to the more polar THF solvent which can result in weakening of the LTBH chelation to the lactone oxygens. Our studies also showed that lactones containing an ester protection group (acetyl or benzoyl) can be chemoselectively reduced to the lactols under certain reduction conditions with $\mathrm{LTBH} / \mathrm{CH}_{2} \mathrm{Cl}_{2}$ combination while the ester moiety remains intact.

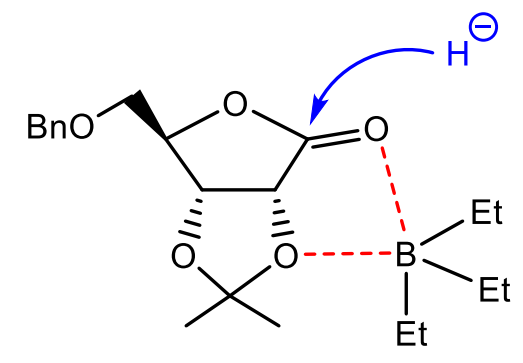

Figure 40. Proposed chelating of borane with exocyclic sugar oxygens 


\section{EXPERIMENTAL}

\subsection{General Procedures}

The ${ }^{1} \mathrm{H}(400 \mathrm{MHz}),{ }^{13} \mathrm{C}(100 \mathrm{MHz})$, or ${ }^{19} \mathrm{~F}(376 \mathrm{MHz})$ NMR spectra were recorded at ambient temperature in solutions of $\mathrm{CDCl}_{3}$ or $\mathrm{MeOH}-\mathrm{d}_{4}$, as noted. The reactions were followed by TLC with Merck Kieselgel 60-F254 sheets, and products were detected with a $254 \mathrm{~nm}$ light or with Hanessian's stain. Column chromatography was performed using Merck Kieselgel 60 (230-400 mesh). Reagent-grade chemicals were used and solvents were dried by reflux distillation over $\mathrm{CaH}_{2}$ under nitrogen gas unless otherwise specified. The carboxylic acid and amine derivatives used for the coupling with gemcitabine were either commercially available or prepared as described. 4-(di-iso-propylsilyl)benzylalcohol was commercially available from Sigma Aldrich. Reactions were carried out under a $\mathrm{N}_{2}$ atmosphere. Phenomenex Gemini RP-C18 with an isocratic mobile phase (various \% $\mathrm{CH}_{3} \mathrm{CN} / \mathrm{H}_{2} \mathrm{O}$ ) was used for some HPLC purification.

\subsection{Synthesis of 4- $N$-Alkyl $\beta$-keto sulfonate gemcitabine analogues}

tert-Butyl $N$-(10-undecenyl) carbamate (57). di-tert-Butyl-dicarbonate (2.20 g, 10.04 mmol) was added to a solution of $\mathbf{5 6}(1.00 \mathrm{~g}, 5.91 \mathrm{mmol})$ in $\mathrm{MeOH}(20 \mathrm{~mL})$ and stirred at ambient temperature. After $18 \mathrm{~h}$, the volatiles were evaporated under reduced pressure and the resulting residue was then column chromatographed (30\% EtOAc/hexane) to give $\mathbf{5 7}^{146}$ $(1.45 \mathrm{~g}, 92 \%)$ as a white solid. ${ }^{1} \mathrm{H} \mathrm{NMR}\left(\mathrm{CDCl}_{3}\right) \delta 1.27\left(\mathrm{~s}, 11 \mathrm{H}, \mathrm{C}\left(\mathrm{CH}_{3}\right)_{3}+\mathrm{CH}_{2}\right), 1.33-$ $1.38\left(\mathrm{~m}, 10 \mathrm{H}, 5 \times \mathrm{CH}_{2}\right), 1.56-1.59\left(\mathrm{~m}, 2 \mathrm{H}, \mathrm{CH}_{2}\right), 2.03\left(\mathrm{dd}, J=6.8,14.4 \mathrm{~Hz}, 2 \mathrm{H}, \mathrm{CH}_{2}\right)$, $3.10\left(\mathrm{t}, J=7.1 \mathrm{~Hz}, 2 \mathrm{H}, \mathrm{CH}_{2}\right), 4.48(\mathrm{br}, 1 \mathrm{H}, \mathrm{NH}), 4.96\left(\mathrm{~m}, 2 \mathrm{H}, \mathrm{CH}_{2}\right), 5.81(\mathrm{~m}, 1 \mathrm{H}, \mathrm{CH})$.

tert-Butyl $N$-(10,11-Dihydroxyundecan-1-yl) carbamate (58). $5 \%$ mol of $\mathrm{OsO}_{4}(50$ $\mu \mathrm{L}$, cat. amount) and $N$-methylmorpholine- $N$-oxide $(87.8 \mathrm{mg}, 0.75 \mathrm{mmol})$ was added to a 
solution of $57(130 \mathrm{mg}, 0.50 \mathrm{mmol})$ in acetone $(2 \mathrm{~mL})$ and water $(0.2 \mathrm{~mL})$, and the mixture was stirred at $0{ }^{\circ} \mathrm{C}$ to ambient temperature under Nitrogen. After $4 \mathrm{~h}$, the reaction mixture was diluted with $\mathrm{CH}_{2} \mathrm{Cl}_{2}(20 \mathrm{~mL})$ and partitioned with $\mathrm{H}_{2} \mathrm{O}$. The organic layer was washed with saturated $\mathrm{NaHCO}_{3} / \mathrm{H}_{2} \mathrm{O}(15 \mathrm{~mL})$, and brine $(15 \mathrm{~mL})$, dried over $\mathrm{Na}_{2} \mathrm{SO}_{4}$, and evaporated, and the resulting residue was column chromatographed (70\% EtOAc/hexane) to give $58(140 \mathrm{mg}, 92 \%) .{ }^{1} \mathrm{H}$ NMR $\left(\mathrm{CDCl}_{3}\right) \delta 1.27\left(\mathrm{~s}, 11 \mathrm{H}, \mathrm{C}\left(\mathrm{CH}_{3}\right)_{3}+\mathrm{CH}_{2}\right), 1.35-1.37$ (m, 14H, $\left.7 \times \mathrm{CH}_{2}\right), 3.07\left(\mathrm{t}, J=7.1 \mathrm{~Hz}, 2 \mathrm{H}, \mathrm{CH}_{2}\right), 3.41(\mathrm{dd}, J=7.7,11.0 \mathrm{~Hz}, 1 \mathrm{H}, \mathrm{CH}), 3.63$ (dd, $J=3.0,11.0 \mathrm{~Hz}, 1 \mathrm{H}, \mathrm{CH}), 3.67-3.70(\mathrm{~m}, 1 \mathrm{H}, \mathrm{CH})$.

tert-Butyl $N$-(10,11-Dihydroxy-11-O-Benzyl-undecane) carbamate (59). Benzyl bromide (47 $\mu \mathrm{L}, 67.7 \mathrm{mg}, 0.40 \mathrm{mmol})$ and $\mathrm{Ag}_{2} \mathrm{O}(115 \mathrm{mg}, 0.50 \mathrm{mmol})$ was added to a solution of $\mathbf{5 8}(100 \mathrm{mg}, 0.33 \mathrm{mmol})$ in $\mathrm{CH}_{2} \mathrm{Cl}_{2}(4 \mathrm{~mL})$. The mixture was stirred at ambient temperature under Nitrogen. After $18 \mathrm{~h}$, the reaction mixture was diluted with $\mathrm{CH}_{2} \mathrm{Cl}_{2}(20$ $\mathrm{mL}$ ) and washed with saturated $\mathrm{NaHCO}_{3} / \mathrm{H}_{2} \mathrm{O}(20 \mathrm{~mL})$, and brine $(15 \mathrm{~mL})$, dried over $\mathrm{Na}_{2} \mathrm{SO}_{4}$, and evaporated, and the resulting residue was column chromatographed (30\% EtOAc/hexane) to give $59(66 \mathrm{mg}, 51 \%) .{ }^{1} \mathrm{H} \mathrm{NMR}\left(\mathrm{CDCl}_{3}\right) \delta 1.26\left(\mathrm{~s}, 11 \mathrm{H}, \mathrm{C}\left(\mathrm{CH}_{3}\right)_{3}+\right.$ $\left.\mathrm{CH}_{2}\right), 1.43-1.45\left(\mathrm{~m}, 14 \mathrm{H}, 7 \times \mathrm{CH}_{2}\right), 3.07-3.10\left(\mathrm{~m}, 2 \mathrm{H}, \mathrm{CH}_{2}\right), 3.32(\mathrm{dd}, J=8.0,9.4 \mathrm{~Hz}, 1 \mathrm{H}$, $\mathrm{CH}), 3.50(\mathrm{dd}, J=3.0,9.4 \mathrm{~Hz}, 1 \mathrm{H}, \mathrm{CH}), 3.78-3.82(\mathrm{~m}, 1 \mathrm{H}, \mathrm{CH}), 4.51\left(\mathrm{~s}, 2 \mathrm{H}, \mathrm{CH}_{2}\right), 7.26-$ $7.43(\mathrm{~m}, 5 \mathrm{H}, \mathrm{Ar})$.

tert-Butyl $N$-(11-O-Benzyl-10-oxoundecanyl) carbamate (60). A freshly prepared solution of Collins reagent $\left[\mathrm{CrO}_{3}(100 \mathrm{mg}, 1.00 \mathrm{mmol})\right.$, pyridine $(81 \mu \mathrm{L}, 100 \mathrm{mg}, 1.00$ mmol), and $\mathrm{Ac}_{2} \mathrm{O}(190 \mu \mathrm{L}, 204 \mathrm{mg}, 2.00 \mathrm{mmol})$ in $\left.\mathrm{CH}_{2} \mathrm{Cl}_{2}(2 \mathrm{~mL})\right]$ was added to a stirred solution of 59 (100 mg, $0.25 \mathrm{mmol})$ in $\mathrm{CH}_{2} \mathrm{Cl}_{2}(8 \mathrm{~mL})$ at ambient temperature. The resulting mixture was stirred for $1 \mathrm{~h}$. and was immediately column chromatographed (EtOAc) to 
give $60(84.5 \mathrm{mg}, 86 \%) .{ }^{1} \mathrm{H}$ NMR $\left(\mathrm{CDCl}_{3}\right) \delta 1.26\left(\mathrm{~s}, 11 \mathrm{H}, \mathrm{C}\left(\mathrm{CH}_{3}\right)_{3}+\mathrm{CH}_{2}\right), 1.44(\mathrm{~m}, 10 \mathrm{H}$, $\left.5 \times \mathrm{CH}_{2}\right), 1.56-1.59\left(\mathrm{~m}, 2 \mathrm{H}, \mathrm{CH}_{2}\right), 2.44\left(\mathrm{t}, J=7.5 \mathrm{~Hz}, 2 \mathrm{H}, \mathrm{CH}_{2}\right), 3.09\left(\mathrm{~m}, 2 \mathrm{H}, \mathrm{CH}_{2}\right), 4.06$ (s, $\left.2 \mathrm{H}, \mathrm{CH}_{2}\right), 4.59\left(\mathrm{~s}, 2 \mathrm{H}, \mathrm{CH}_{2}\right), 7.28-7.42(\mathrm{~m}, 5 \mathrm{H}, \mathrm{Ar})$.

tert-Butyl $N$-(10,11-Dihydroxy-11- $O$-methanesulfnonylundecanyl) carbamate (64). Mesyl chloride ( $29.8 \mathrm{mg}, 20 \mu \mathrm{L}, 0.26 \mathrm{mmol})$ was added to a solution of $\mathbf{5 8}(80 \mathrm{mg}$, $0.26 \mathrm{mmol})$ in anhydrous $\mathrm{CH}_{2} \mathrm{Cl}_{2}(2 \mathrm{~mL})$ in the presence of $\mathrm{Et}_{3} \mathrm{~N}(39.5 \mathrm{mg}, 54 \mu \mathrm{L}, 0.39$ mmol). The mixture was stirred at $-20{ }^{\circ} \mathrm{C}$. After 20 minutes, the reaction mixture was diluted with $\mathrm{CH}_{2} \mathrm{Cl}_{2}$ and partitioned with $\mathrm{HCl}(0.1 \mathrm{M}, 15 \mathrm{~mL})$ and $\mathrm{H}_{2} \mathrm{O}(15 \mathrm{~mL})$. The organic layer was washed with saturated $\mathrm{NaHCO}_{3} / \mathrm{H}_{2} \mathrm{O}(15 \mathrm{~mL})$, and brine $(15 \mathrm{~mL})$, dried over $\mathrm{Na}_{2} \mathrm{SO}_{4}$, and evaporated, and the resulting residue was column chromatographed (40\% EtOAc/hexane) to give $64(54 \mathrm{mg}, 55 \%) .{ }^{1} \mathrm{H} \mathrm{NMR}\left(\mathrm{CDCl}_{3}\right) \delta 1.28\left(\mathrm{~s}, 11 \mathrm{H}, \mathrm{C}\left(\mathrm{CH}_{3}\right)_{3}\right.$ $\left.+\mathrm{CH}_{2}\right), 1.44\left(\mathrm{~m}, 14 \mathrm{H}, 7 \times \mathrm{CH}_{2}\right), 3.08(\mathrm{~s}, 3 \mathrm{H}, \mathrm{Ms}), 3.09\left(\mathrm{~m}, 2 \mathrm{H}, \mathrm{CH}_{2}\right), 3.70(\mathrm{~m}, 1 \mathrm{H}, \mathrm{CH})$, $4.10(\mathrm{dd}, J=7.2,10.6 \mathrm{~Hz}, 1 \mathrm{H}, \mathrm{CH}), 4.25(\mathrm{dd}, J=2.9,10.5 \mathrm{~Hz}, 1 \mathrm{H}, \mathrm{CH})$.

tert-Butyl $N$-(11-O-Mesyl-10-oxoundecanyl) carbamate (65). A freshly prepared solution of Collins reagent $\left[\mathrm{CrO}_{3}(52 \mathrm{mg}, 0.52 \mathrm{mmol})\right.$, pyridine $(8 \mu \mathrm{L}, 52 \mathrm{mg}, 0.52 \mathrm{mmol})$, and $\mathrm{Ac}_{2} \mathrm{O}(102 \mu \mathrm{L}, 107 \mathrm{mg}, 1.04 \mathrm{mmol})$ in $\left.\mathrm{CH}_{2} \mathrm{Cl}_{2}(2 \mathrm{~mL})\right]$ was added to a stirred solution of $64(50 \mathrm{mg}, 0.13 \mathrm{mmol})$ in $\mathrm{CH}_{2} \mathrm{Cl}_{2}(8 \mathrm{~mL})$ at ambient temperature. The resulting mixture was stirred for $1 \mathrm{~h}$. and was immediately column chromatographed (45\% EtOAc/hexane) to give $65(45 \mathrm{mg}, 92 \%) .{ }^{1} \mathrm{H} \mathrm{NMR}\left(\mathrm{CDCl}_{3}\right) \delta 1.28\left(\mathrm{~s}, 11 \mathrm{H}, \mathrm{C}\left(\mathrm{CH}_{3}\right)_{3}+\mathrm{CH}_{2}\right), 1.44(\mathrm{~m}, 10 \mathrm{H}$, $\left.5 \times \mathrm{CH}_{2}\right), 1.58\left(\mathrm{~m}, 2 \mathrm{H}, \mathrm{CH}_{2}\right), 2.45\left(\mathrm{t}, J=7.4 \mathrm{~Hz}, 2 \mathrm{H}, \mathrm{CH}_{2}\right), 3.10\left(\mathrm{~m}, 2 \mathrm{H}, \mathrm{CH}_{2}\right), 3.20(\mathrm{~s}$, $3 \mathrm{H}, \mathrm{Ms}), 4.49$ (s, 2H, $\mathrm{CH}_{2}$ ).

tert-Butyl $N$-(11-Fluoro-10-oxoundecanyl) carbamate (66). To a solution of KF (6.4 $\mathrm{mg}, 0.11 \mathrm{mmol}), \mathrm{K}_{2} \mathrm{CO}_{3}(15.2 \mathrm{mg}, 0.11 \mathrm{mmol})$, Kryptofix $2.2 .2(41 \mathrm{mg}, 0.11 \mathrm{mmol})$ in 
$\mathrm{CH}_{3} \mathrm{CN}(2 \mathrm{~mL}), \mathbf{6 5}(10.0 \mathrm{mg}, 0.026 \mathrm{mmol})$ was added and stirred at $80{ }^{\circ} \mathrm{C}$. After $25 \mathrm{~min}$, the reaction mixture was quickly cooled in a water bath and filtered. The crude product was evaporated, and the resulting residue was column chromatographed (35\% EtOAc/hexane) to give $66(4.1 \mathrm{mg}, 50 \%) .{ }^{1} \mathrm{H} \mathrm{NMR}\left(\mathrm{CDCl}_{3}\right) \delta 1.28\left(\mathrm{~s}, 11 \mathrm{H}, \mathrm{C}\left(\mathrm{CH}_{3}\right)_{3}+\right.$ $\left.\mathrm{CH}_{2}\right), 1.44\left(\mathrm{~m}, 10 \mathrm{H}, 5 \times \mathrm{CH}_{2}\right), 1.58\left(\mathrm{~m}, 2 \mathrm{H}, \mathrm{CH}_{2}\right), 2.44\left(\mathrm{t}, J=7.5 \mathrm{~Hz}, 2 \mathrm{H}, \mathrm{CH}_{2}\right), 3.10(\mathrm{~m}$, $\left.2 \mathrm{H}, \mathrm{CH}_{2}\right), 4.75\left(\mathrm{~d}, J=47.7 \mathrm{~Hz}, 2 \mathrm{H}, \mathrm{CH}_{2} \mathrm{~F}\right) .{ }^{19} \mathrm{~F}$ NMR $\delta-227.41(\mathrm{t}, J=47.7,1 \mathrm{~F})$.

4- $N$-(p-Toluenosulfonyl)-2'-deoxy-2', $\mathbf{2}^{\prime}$-difluorocytidine (62). TMSCl (2.5 mL) was added to a suspension of Gemcitabine 1 ( $300 \mathrm{mg}, 1.0 \mathrm{mmol}$ ) in anhydrous pyridine $(5 \mathrm{~mL})$, and the mixture was stirred at ambient temperature under Nitrogen. After $2 \mathrm{~h}, \mathrm{TsCl}(1.80$ $\mathrm{g}, 10.01 \mathrm{mmol}$ ) was added, and the reaction mixture was heated to $60^{\circ} \mathrm{C}$ and kept stirring. After $24 \mathrm{~h}$, volatiles were evaporated, and the resulting residue was treated with $\mathrm{MeOH} / \mathrm{NH}_{3}(5 \mathrm{~mL})$ and stirred at ambient temperature for $8 \mathrm{~h}$. The volatiles were then evaporated under reduced pressure, and the resulting residue was column chromatographed (90\% EtOAc/Hexane) to give $\mathbf{6 2}^{28}(378.7 \mathrm{mg}, 90 \%)$ as a white-yellow solid. ${ }^{1} \mathrm{H}$ NMR $\left(\mathrm{CD}_{3} \mathrm{OD}\right) \delta 2.42\left(\mathrm{~s}, 3 \mathrm{H}, \mathrm{CH}_{3}\right), 3.78(\mathrm{dd}, J=3.4,12.8 \mathrm{~Hz}, 1 \mathrm{H}, \mathrm{H} 5$ '), 3.90-3.95 (m, 2H, H4,H5"), 4.28 (dt, $\left.J=8.4,12.0 \mathrm{~Hz}, 1 \mathrm{H}, \mathrm{H3} 3^{\prime}\right), 6.13$ (dd, $\left.J=5.3,9.5 \mathrm{~Hz}, 1 \mathrm{H}, \mathrm{H} 1^{\prime}\right), 6.65$ (d, J $=8.2 \mathrm{~Hz}, 1 \mathrm{H}, \mathrm{H} 5), 7.36(\mathrm{~d}, J=8.0 \mathrm{~Hz}, 2 \mathrm{H}, \mathrm{Ar}), 7.79(\mathrm{~d}, J=8.3 \mathrm{~Hz}, 2 \mathrm{H}, \mathrm{Ar}), 7.99(\mathrm{~d}, J=$ $8.1 \mathrm{~Hz}, 1 \mathrm{H}, \mathrm{H6}$ ). ${ }^{13} \mathrm{C}$ NMR $\delta 21.43,60.34\left(\mathrm{C}^{\prime}\right), 70.21\left(\mathrm{dd}, J=18.8,27.2 \mathrm{~Hz}, \mathrm{C}^{\prime}\right), 82.99$ (d, $J=8.4, \mathrm{C} 4$ '), $85.46\left(\mathrm{dd}, J=23.9,41.3 \mathrm{~Hz}, \mathrm{C} 1^{\prime}\right), 98.46(\mathrm{C} 5), 123.84(\mathrm{t}, J=258.7 \mathrm{~Hz}$, C2'), 127.58 (Ar), 130.52 (Ar), 140.71 (Ar), 142.62 (C6), $144.66(\mathrm{Ar}), 150.21(\mathrm{C} 2), 160.54$ (C4). ${ }^{19}$ F NMR $\delta-120.17$ (br s, 1F), -119.41 (dd, $\left.J=4.1,12.7 \mathrm{~Hz}, 1 \mathrm{~F}\right)$.

4- $N$-(Uundec-10-en-1-yl)-2'-deoxy-2',2'-difluorocytidine (67). 10-undecene amine $(0.49 \mathrm{~mL}, 2.16 \mathrm{mmol})$ was added to a suspension of $\mathbf{6 2}(300 \mathrm{mg}, 0.72 \mathrm{mmol})$ in 1,4-dioxane 
$(4.1 \mathrm{~mL})$ and $\mathrm{Et}_{3} \mathrm{~N}(0.302 \mathrm{~mL}, 219 \mathrm{mg}, 2.16 \mathrm{mmol})$ and the mixture was left stirring at $65^{\circ} \mathrm{C}$. After $24 \mathrm{~h}$, volatiles were evaporated and the resulting residue was column chromatographed (5\% $\left.\mathrm{MeOH} / \mathrm{CHCl}_{3}\right)$ to give $67^{28}(254 \mathrm{mg}, 85 \%) .{ }^{1} \mathrm{H}$ NMR $\left(\mathrm{CD}_{3} \mathrm{OD}\right) \delta$ 1.30-1.43 (m, 12H, $\left.6 \times \mathrm{CH}_{2}\right), 1.56-1.65\left(\mathrm{~m}, 2 \mathrm{H}, \mathrm{CH}_{2}\right), 2.03-2.09\left(\mathrm{~m}, 2 \mathrm{H}, \mathrm{CH}_{2}\right), 3.39(\mathrm{t}, J$ $\left.=7.1 \mathrm{~Hz}, 2 \mathrm{H}, \mathrm{CH}_{2}\right), 3.80\left(\mathrm{dd}, J=3.3,12.6 \mathrm{~Hz}, 1 \mathrm{H}, \mathrm{H} 5^{\prime}\right), 3.89(\mathrm{td}, J=2.8,8.3 \mathrm{~Hz}, 1 \mathrm{H}$, H4'), $3.95\left(\mathrm{~d}, J=12.6 \mathrm{~Hz}, 1 \mathrm{H}, \mathrm{H} 5^{\prime \prime}\right), 4.26\left(\mathrm{dt}, J=8.3,12.1 \mathrm{~Hz}, 1 \mathrm{H}, \mathrm{H} 3^{\prime}\right), 4.91-5.02(\mathrm{~m}$, 2H, $\mathrm{CH}_{2}$ ), 5.82 (tdd, $\left.J=6.7,10.3,17.0 \mathrm{~Hz}, 1 \mathrm{H}, \mathrm{CH}\right), 5.87(\mathrm{~d}, J=7.6 \mathrm{~Hz}, 1 \mathrm{H}, \mathrm{H} 5), 6.23(\mathrm{t}$, $\left.J=8.0 \mathrm{~Hz}, 1 \mathrm{H}, \mathrm{H} 1^{\prime}\right), 7.74(\mathrm{~d}, J=7.6 \mathrm{~Hz}, 1 \mathrm{H}, \mathrm{H} 6) .{ }^{13} \mathrm{C} \mathrm{NMR} \delta 28.01,29.98,30.12,30.19$, 30.42, 30.51, 30.63, 34.88, 41.75, $60.56\left(\mathrm{C}^{\prime}\right), 70.67$ (dd, $\left.J=22.4,23.8 \mathrm{~Hz}, \mathrm{C}^{\prime}\right), 82.26$ (dd, $\left.J=3.6,5.0 \mathrm{~Hz}, \mathrm{C} 4{ }^{\prime}\right), 85.94\left(\mathrm{dd}, J=26.0,38.0 \mathrm{~Hz}, \mathrm{C} 1^{\prime}\right), 97.33$ (C5), 114.68, 124.05 (t, $J=258.4 \mathrm{~Hz}, \mathrm{C} 2$ ') $, 140.16,140.77$ (C6), 158.30 (C2), 165.37 (C4). ${ }^{19}$ F NMR $\delta-119.89$ (br d, $J=240.1 \mathrm{~Hz}, 1 \mathrm{~F}),-118.80$ (br d, $J=240.1 \mathrm{~Hz}, 1 \mathrm{~F})$.

\section{4- $N$-(Uundec-10-en-1-yl)-3',5'-di- $O$-benzoyl-2'-deoxy-2',2'-difluorocytidine (68).} $\mathrm{BzCl}(140 \mu \mathrm{L}, 1.2 \mathrm{mmol})$ was added to a solution of 67 (200 $\mathrm{mg}, 0.48 \mathrm{mmol}), 2,6$-lutidine (223 $\mu \mathrm{L}, 1.92 \mathrm{mmol})$, and 4-dimethylaminopyridine (117.3 mg, $0.96 \mathrm{mmol})$ in $\mathrm{CH}_{2} \mathrm{Cl}_{2}$ (10 $\mathrm{mL}$ ), and the mixture was stirred at $35^{\circ} \mathrm{C}$ under Nitrogen. After $6 \mathrm{~h}$, the reaction mixture was diluted with $\mathrm{CH}_{2} \mathrm{Cl}_{2}(40 \mathrm{~mL})$ and partitioned with $\mathrm{H}_{2} \mathrm{O}$, and the aqueous layer was extracted with $\mathrm{CH}_{2} \mathrm{Cl}_{2}(2 \times 15 \mathrm{~mL})$. The combined organic layers were sequentially washed with $1 \mathrm{M} \mathrm{HCl}(15 \mathrm{~mL})$, saturated $\mathrm{NaHCO}_{3} / \mathrm{H}_{2} \mathrm{O}(15 \mathrm{~mL})$, and brine $(15 \mathrm{~mL})$, dried over $\mathrm{Na}_{2} \mathrm{SO}_{4}$, and evaporated, and the resulting residue $(240 \mathrm{mg}$ ) was column chromatographed $\left(2 \% \mathrm{MeOH} / \mathrm{CHCl}_{3}\right)$ to give $\mathbf{6 8}(230 \mathrm{mg}, 78 \%)$ as a mixture of isomers. The major isomer had the following peaks: ${ }^{1} \mathrm{H}$ NMR $\left(\mathrm{CDCl}_{3}\right) \delta 1.16-1.41\left(\mathrm{~m}, 12 \mathrm{H}, 6 \times \mathrm{CH}_{2}\right), 1.49-1.63(\mathrm{~m}$, $\left.2 \mathrm{H}, \mathrm{CH}_{2}\right), 1.93-2.05\left(\mathrm{~m}, 2 \mathrm{H}, \mathrm{CH}_{2}\right), 3.37$ (t, $\left.J=7.1 \mathrm{~Hz}, 2 \mathrm{H}, \mathrm{CH}_{2}\right), 4.48-4.58\left(\mathrm{~m}, 1 \mathrm{H}, \mathrm{H}^{\prime}\right)$, 
4.62-4.82 (m, 2H, H5', H5"), 4.87-5.01 (m, 2H, $\mathrm{CH}_{2}$ ), 5.53-5.66 (m, 1H, H3'), 5.76-5.84 (tdd, $J=6.7,10.3,17 \mathrm{~Hz}, 1 \mathrm{H}, \mathrm{CH}), 5.73(\mathrm{~d}, J=7.6 \mathrm{~Hz}, 1 \mathrm{H}, \mathrm{H}$ ), 6.57-6.60 (m, 1H, H1'), $7.29(\mathrm{dd}, J=0.6,7.3,1 \mathrm{H}, \mathrm{H6}), 7.37-7.49(\mathrm{~m}, 4 \mathrm{H}, \mathrm{Ar}), 7.51-7.66(\mathrm{~m}, 2 \mathrm{H}, \mathrm{Ar}), 7.89-8.10$ (m, 4H, Ar). ${ }^{13} \mathrm{C}$ NMR $\delta 26.67,28.65,28.87,29.02,29.28,29.34,29.69,33.78,43.97$, $62.55\left(\mathrm{C}^{\prime}\right), 71.35$ (dd, $J=17.1,35.2 \mathrm{~Hz}, \mathrm{C} 3$ '), 79.57 (C4'), 83.54 (br s, C1'), 91.04 (C5), 114.17, 120.93 (t, $\left.J=263.1 \mathrm{~Hz}, \mathrm{C}^{\prime}\right)$ ), 126.78, 128.48, 128.73, 128.83, 129.36, 129.63, 129.72, 130.17, 133.58, 134.50, 139.16 (C6), 157.82 (C2), 165.99 (C4), 171.67. ${ }^{19}$ F NMR $\delta-120.35($ br d, $J=203.2 \mathrm{~Hz}, 1 \mathrm{~F}),-115.31($ br d, $J=246.5 \mathrm{~Hz}, 1 \mathrm{~F})$.

\section{4- $N$-(10,11-Dihydroxyundecan-1-yl)-3',5'-di-O-benzoyl-2'-deoxy-2',2'-}

difluorocytidine (69). $5 \% \mathrm{~mol}$ of $\mathrm{OsO}_{4}(100 \mu \mathrm{L}$, catalytic amount) and $N$ methylmorpholine- $N$-oxide $(56.20 \mathrm{mg}, 0.48 \mathrm{mmol})$ was added to a solution of $\mathbf{6 8}(200 \mathrm{mg}$, $0.32 \mathrm{mmol})$ in acetone $(3 \mathrm{~mL})$ and water $(0.3 \mathrm{~mL})$, and the mixture was stirred at $0{ }^{\circ} \mathrm{C}$ to ambient temperature under nitrogen. After $2 \mathrm{~h}$, the reaction mixture was diluted with $\mathrm{CH}_{2} \mathrm{Cl}_{2}(30 \mathrm{~mL})$ and partitioned with $\mathrm{H}_{2} \mathrm{O}(15 \mathrm{~mL})$. The organic layer was washed with saturated $\mathrm{NaHCO}_{3} / \mathrm{H}_{2} \mathrm{O}(15 \mathrm{~mL})$, and brine $(15 \mathrm{~mL})$, dried over $\mathrm{Na}_{2} \mathrm{SO}_{4}$, and evaporated, and the resulting residue (198 mg) was column chromatographed (90\% EtOAc/hexane) to give $69(202 \mathrm{mg}, 96 \%)$ as a mixture of rotamers. The major rotamer had the following peaks: ${ }^{1} \mathrm{H}$ NMR $\left(\mathrm{CDCl}_{3}\right) \delta 1.21-1.40\left(\mathrm{~m}, 12 \mathrm{H}, 6 \times \mathrm{CH}_{2}\right), 1.39-1.43\left(\mathrm{~m}, 2 \mathrm{H}, \mathrm{CH}_{2}\right), 1.57-$ $1.60\left(\mathrm{~m}, 2 \mathrm{H}, \mathrm{CH}_{2}\right), 3.43-3.45\left(\mathrm{~m}, 2 \mathrm{H}, \mathrm{CH}_{2}\right), 3.63-3.66(\mathrm{~m}, 1 \mathrm{H}, \mathrm{CH}), 3.71-3.73(\mathrm{~m}, 1 \mathrm{H}$, $\mathrm{CH}_{2}$ ), 4.54-4.56 (m, 1H, H4'), 4.75 (dd, $\left.J=4.6,12.2 \mathrm{~Hz}, 1 \mathrm{H}, \mathrm{H} 5^{\prime}\right), 4.77$ (dd, $J=3.3,12.1$ Hz, 1H, H5"), 5.60-5.63 (m, 1H, H3'), 5.71 (d, $J=7.6 \mathrm{~Hz}, 1 \mathrm{H}, \mathrm{H}$ ), 6.59-6.62 (m, 1H, H1'), 7.33 (d, $J=7.0,1 \mathrm{H}, \mathrm{H6}$ ), 7.39-7.51 (m, 4H, Ar), 7.52-7.67 (m, 2H, Ar), 7.98-8.10 (m, 4H, Ar). ${ }^{13} \mathrm{C}$ NMR $\delta 25.28,26.41,26.61,28.57,28.70,28.85,29.19,33.02,43.70$, 
$62.55\left(\mathrm{C}^{\prime}\right), 66.85,71.61\left(\mathrm{~m}, \mathrm{C} 33^{\prime}\right), 72.22,77.81,79.25,91.34(\mathrm{C} 5), 121.14(\mathrm{t}, J=263.1$ Hz, C2'), 127.64, 128.70, 128.80, 129.07, 129.71, 130.15, 133.56, 133.72, 134.17, 134.43, $158.82,164.79,165.97 .{ }^{19} \mathrm{~F}$ NMR $\delta-120.42($ br d $, J=243.4 \mathrm{~Hz}, 1 \mathrm{~F}),-115.30($ br d, $J=$ $260.1 \mathrm{~Hz}, 1 \mathrm{~F})$. HRMS (ESI+) $\mathrm{m} / \mathrm{z}$ calcd for $\mathrm{C}_{34} \mathrm{H}_{41} \mathrm{~F}_{2} \mathrm{~N}_{3} \mathrm{O}_{8}[\mathrm{M}+\mathrm{H}]+$, 658.2934; found, 658.2930

\section{4- $N$-(10,11-Dihydroxy-11- $O$-methanesulfnonylundecanyl)-3',5'-di- $O$-benzoyl-2'-}

deoxy-2', $\mathbf{2}^{\prime}$-difluorocytidine (70). Mesyl chloride (14 $\left.\mu \mathrm{L}, 20.7 \mathrm{mg}, 0.18 \mathrm{mmol}\right)$ was added to a solution of $69(100 \mathrm{mg}, 0.15 \mathrm{mmol})$ in anhydrous $\mathrm{CH}_{2} \mathrm{Cl}_{2}(4 \mathrm{~mL})$ in the presence of $\mathrm{Et}_{3} \mathrm{~N}(32 \mu \mathrm{L}, 23 \mathrm{mg}, 0.23 \mathrm{mmol})$. The mixture was stirred at $-20^{\circ} \mathrm{C}$. After 20 minutes, the reaction mixture was diluted with $\mathrm{CH}_{2} \mathrm{Cl}_{2}$ and partitioned with $\mathrm{HCl}(0.1 \mathrm{M}, 15 \mathrm{~mL})$ and $\mathrm{H}_{2} \mathrm{O}(15 \mathrm{~mL})$. The organic layer was washed with saturated $\mathrm{NaHCO}_{3} / \mathrm{H}_{2} \mathrm{O}(15 \mathrm{~mL})$, and brine (15 mL), dried over $\mathrm{Na}_{2} \mathrm{SO}_{4}$, and evaporated, and the resulting residue was column chromatographed (50\% EtOAc/hexane) to give $\mathbf{7 0}(93 \mathrm{mg}, 55 \%)$ as a mixture of rotamers. The major rotamer had the following peaks. ${ }^{1} \mathrm{H}$ NMR $\left(\mathrm{CDCl}_{3}\right) \delta 1.21-1.40(\mathrm{~m}, 12 \mathrm{H}, 6 \times$ $\left.\mathrm{CH}_{2}\right), 1.44-1.47\left(\mathrm{~m}, 2 \mathrm{H}, \mathrm{CH}_{2}\right), 1.56-1.59\left(\mathrm{~m}, 2 \mathrm{H}, \mathrm{CH}_{2}\right), 3.08$ (s, 3H, Ms), 3.48-3.50 (m, 2H, $\left.\mathrm{CH}_{2}\right), 3.91-3.94(\mathrm{~m}, 1 \mathrm{H}, \mathrm{CH}), 4.12(\mathrm{dd}, J=2.8,9.9 \mathrm{~Hz}, 1 \mathrm{H}, \mathrm{CH}), 4.25(\mathrm{dd}, J=3.1$, $10.5 \mathrm{~Hz}, 1 \mathrm{H}, \mathrm{CH}), 4.50-4.54\left(\mathrm{~m}, 1 \mathrm{H}, \mathrm{H} 4^{\prime}\right), 4.65$ (dd, $\left.J=4.5,12.2,1 \mathrm{H}, \mathrm{H} 5^{\prime}\right), 4.79(\mathrm{dd}, J=$ 3.2, 12.1, H5"), 5.58-5.61 (m, 1H, H3'), 5.69 (d, $J=7.6 \mathrm{~Hz}, 1 \mathrm{H}, \mathrm{H} 5), 6.58-6.61$ (m, 1H, H1'), $7.30(\mathrm{~d}, J=7.3,1 \mathrm{H}, \mathrm{H6}$ ), 7.39-7.51 (m, 4H, Ar), 7.52-7.67 (m, 2H, Ar), 7.98-8.10 (m, 4H, Ar). ${ }^{13} \mathrm{C}$ NMR $\delta 25.24,26.79,29.08,29.14,29.25,29.28,29.31,32.87,37.69$, 41.12, 63.03 (C5'), 69.74, 71.81 (br s, C3'), 73.92, 77.95, 79.27 (C4'), 83.79 (s, C1'), 96.12 (C5), 120.89 (t, $J=263.2 \mathrm{~Hz}, \mathrm{C} 2$ '), 126.95, 128.14, 128.75, 128.85, 129.44, 129.86, 130.32, 
$133.65,134.33,140.05,155.69,165.09,166.12 .{ }^{19} \mathrm{~F}$ NMR $\delta-120.26$ (br d, $J=222.8 \mathrm{~Hz}$, 1F), -115.21 (br d, $J=246.2 \mathrm{~Hz}, 1 \mathrm{~F})$.

\section{4- $N$-(10,11-Dihydroxy-11- $O$-toluenosulfonylundecanyl)-3',5'-di- $O$-benzoyl-2'-}

deoxy-2', $\mathbf{2}^{\prime}$-difluorocytidine (71). Tosyl chloride $(29.6 \mathrm{mg}, 0.15 \mathrm{mmol})$ was added to a solution of 70 (100 mg, $0.15 \mathrm{mmol})$ in anhydrous $\mathrm{CH}_{2} \mathrm{Cl}_{2}(4 \mathrm{~mL})$ in the presence of $\mathrm{Et}_{3} \mathrm{~N}$ (32 $\mu \mathrm{L}, 23 \mathrm{mg}, 0.23 \mathrm{mmol}$ ). The mixture was stirred at $40{ }^{\circ} \mathrm{C}$. After $15 \mathrm{~h}$, the reaction mixture was diluted with $\mathrm{CH}_{2} \mathrm{Cl}_{2}$ and partitioned with $\mathrm{HCl}(0.1 \mathrm{M}, 5 \mathrm{~mL})$ and $\mathrm{H}_{2} \mathrm{O}(15$ $\mathrm{mL})$. The organic layer was washed with saturated $\mathrm{NaHCO}_{3} / \mathrm{H}_{2} \mathrm{O}(15 \mathrm{~mL})$, and brine (15 $\mathrm{mL}$ ), dried over $\mathrm{Na}_{2} \mathrm{SO}_{4}$, and evaporated, and the resulting residue was column chromatographed (45\% EtOAc/hexane) to give $\mathbf{7 1}(76 \mathrm{mg}, 62 \%)$ as a mixture of rotamers. The major rotamer had the following peaks. ${ }^{1} \mathrm{H}$ NMR $\left(\mathrm{CDCl}_{3}\right) \delta 1.23-1.31(\mathrm{~m}, 12 \mathrm{H}, 6 \times$ $\left.\mathrm{CH}_{2}\right), 1.44-1.46\left(\mathrm{~m}, 2 \mathrm{H}, \mathrm{CH}_{2}\right), 1.62-1.65\left(\mathrm{~m}, 2 \mathrm{H}, \mathrm{CH}_{2}\right), 2.44\left(\mathrm{~s}, 3 \mathrm{H}, \mathrm{CH}_{3}\right), 3.46-3.49(\mathrm{~m}$, $\left.2 \mathrm{H}, \mathrm{CH}_{2}\right), 3.82-3.85(\mathrm{~m}, 1 \mathrm{H}, \mathrm{CH}), 3.91(\mathrm{~m}, 1 \mathrm{H}, \mathrm{CH}), 4.11(\mathrm{dd}, J=2.9,9.8 \mathrm{~Hz}, 1 \mathrm{H}, \mathrm{CH})$, 4.51-4.54 (m, 1H, H4'), $4.66\left(\mathrm{dd}, J=4.4,12.2 \mathrm{~Hz}, 1 \mathrm{H}, \mathrm{H} 5^{\prime}\right), 4.81$ (dd, $J=3.4,12.3 \mathrm{~Hz}$, 1H, H5"), 5.38-5.41 (m, 1H, H3'), 5.61 (d, $J=7.6 \mathrm{~Hz}, 1 \mathrm{H}, \mathrm{H} 5), 6.64-6.66$ (m, 1H, H1'), 7.33-7.36 (m, 3H, H6, Ts), 7.39-7.51 (m, 4H, Ar), 7.52-7.67 (m, 2H, Ar), 7.98-8.10 (m, $4 \mathrm{H}, \mathrm{Ar}) .{ }^{13} \mathrm{C}$ NMR $\delta 21.80,25.21,26.87,29.32,29.35,29.41,29.58,29.85,32.77,41.17$, 63.03 (C5'), 69.62, 71.15 (m, C3'), 74.14, 96.02 (C5), 121.19 (t, $\left.J=262.8 \mathrm{~Hz}, \mathrm{C2}{ }^{\prime}\right), 128.11$, $128.75,128.89,129.45,129.49,129.86,130.10,130.33,132.91,133.65,134.32,145.19$, $164.85,165.09,166.11 .{ }^{19} \mathrm{~F}$ NMR $\delta-120.51(\mathrm{br} d, J=241.2 \mathrm{~Hz}, 1 \mathrm{~F}),-115.34(\mathrm{~d}, J=246.8$ $\mathrm{Hz}, 1 \mathrm{~F})$.

\section{4- $N$-(11-O-Mesyl-10-oxoundecanyl)-3',5'-di- $O$-benzoyl-2'-deoxy-2',2'-}

difluorocytidine (72). A freshly prepared solution of Collins reagent $\left[\mathrm{CrO}_{3}(28 \mathrm{mg}, 0.28\right.$ 
mmol), pyridine ( $7 \mu \mathrm{L}, 28 \mathrm{mg}, 0.28 \mathrm{mmol})$, and $\mathrm{Ac}_{2} \mathrm{O}(53 \mu \mathrm{L}, 60 \mathrm{mg}, 0.56 \mathrm{mmol})$ in $\mathrm{CH}_{2} \mathrm{Cl}_{2}(4 \mathrm{~mL})$ ] was added to a stirred solution of $\mathbf{7 1}(50 \mathrm{mg}, 0.07 \mathrm{mmol})$ in $\mathrm{CH}_{2} \mathrm{Cl}_{2}(8 \mathrm{~mL})$ at ambient temperature. The resulting mixture was stirred for $1 \mathrm{~h}$. and was immediately column chromatographed (EtOAc) to give $72(48 \mathrm{mg}, 93 \%)$ as a mixture of isomers. The major isomer had the following peaks. ${ }^{1} \mathrm{H} \mathrm{NMR}\left(\mathrm{CDCl}_{3}\right) \delta 1.22-1.35\left(\mathrm{~m}, 12 \mathrm{H}, 6 \times \mathrm{CH}_{2}\right)$, 1.53-1.56 (m, 2H, $\left.\mathrm{CH}_{2}\right), 2.45$ (t, $\left.J=7.3 \mathrm{~Hz}, 2 \mathrm{H}, \mathrm{CH}_{2}\right), 3.19(\mathrm{~s}, 3 \mathrm{H}, \mathrm{Ms}), 3.48-3.50(\mathrm{~m}, 2 \mathrm{H}$, $\mathrm{CH}_{2}$ ), 4.51-4.53 (m, 1H, H4'), 4.66 (dd, $\left.J=4.6,12.3 \mathrm{~Hz}, 1 \mathrm{H}, \mathrm{H} 5^{\prime}\right), 4.78$ (s, 2H, $\left.\mathrm{CH}_{2}\right), 4.79$ (dd, $\left.J=3.6,12.1 \mathrm{~Hz}, 1 \mathrm{H}, \mathrm{H} 5^{\prime \prime}\right), 5.40-5.42\left(\mathrm{~m}, 1 \mathrm{H}, \mathrm{H} 3^{\prime}\right), 5.60$ (d, $\left.J=7.6 \mathrm{~Hz}, 1 \mathrm{H}, \mathrm{H} 5\right), 6.61-$ $6.63\left(\mathrm{~m}, 1 \mathrm{H}, \mathrm{H1} 1^{\prime}\right), 7.32$ (d, J = 7.3, 1H, H6), 7.41-7.52 (m, 4H, Ar), 7.55-7.67 (m, 2H, Ar), 8.02-8.11 (m, 4H, Ar). ${ }^{13} \mathrm{C}$ NMR $\delta 23.14,26.70,28.92,29.02,29.07,29.20,29.83,38.98$, 39.67, 39.78, 44.37, 48.37, 62.91 (C5'), 71.63 (dd, $J=17.2,35.4$ Hz, C3'), 71.79, 79.38 (C4'), 83.85 (br s, C1'), 91.32 (C5), 120.93 (t, $J=263.1 \mathrm{~Hz}, \mathrm{C} 2$ '), 127.79, 128.85, 128.95, 129.24, 129.86, 130.30, 133.56, 133.71, 134.21, 134.42, 138.78 (C6), 146.88 (C4), 158.12, 164.93, 166.09, 203.17. ${ }^{19} \mathrm{~F}$ NMR $\delta-120.21(\mathrm{br} d, J=224.5 \mathrm{~Hz}, 1 \mathrm{~F}),-115.21(\mathrm{~d}, J=245.4$ $\mathrm{Hz}, 1 \mathrm{~F})$.

\section{4- $N$-(11- $O$-Toluenosulfonyl-10-oxoundecanyl)-3',5'-di- $O$-benzoyl-2'-deoxy-2',2'-}

difluorocytidine (73). A freshly prepared solution of Collins reagent $\left[\mathrm{CrO}_{3}(24.6 \mathrm{mg}\right.$, $0.246 \mathrm{mmol}$ ), pyridine (5 $\mu \mathrm{L}, 24.6 \mathrm{mg}, 0.246 \mathrm{mmol})$, and $\mathrm{Ac}_{2} \mathrm{O}(45 \mu \mathrm{L}, 51 \mathrm{mg}, 0.493$ $\mathrm{mmol})$ in $\left.\mathrm{CH}_{2} \mathrm{Cl}_{2}(2 \mathrm{~mL})\right]$ was added to a stirred solution of $71(50 \mathrm{mg}, 0.062 \mathrm{mmol})$ in $\mathrm{CH}_{2} \mathrm{Cl}_{2}(4 \mathrm{~mL})$ at ambient temperature. The resulting mixture was stirred for $1 \mathrm{~h}$. and was immediately column chromatographed (EtOAc) to give $\mathbf{7 3}(47.2 \mathrm{mg}, 94 \%)$ as a mixture of isomers. The major isomer had the following peaks. ${ }^{1} \mathrm{H}$ NMR $\left(\mathrm{CDCl}_{3}\right) \delta 1.23-1.31(\mathrm{~m}$, $\left.12 \mathrm{H}, 6 \times \mathrm{CH}_{2}\right), 1.44-1.46\left(\mathrm{~m}, 2 \mathrm{H}, \mathrm{CH}_{2}\right), 2.44\left(\mathrm{~s}, 3 \mathrm{H}, \mathrm{CH}_{3}\right), 2.48-2.50\left(\mathrm{~m}, 2 \mathrm{H}, \mathrm{CH}_{2}\right), 3.50-$ 
$3.52\left(\mathrm{~m}, 2 \mathrm{H}, \mathrm{CH}_{2}\right), 4.49\left(\mathrm{~s}, 2 \mathrm{H}, \mathrm{CH}_{2}\right), 4.51-4.53\left(\mathrm{~m}, 1 \mathrm{H}, \mathrm{H} 4^{\prime}\right), 4.67(\mathrm{dd}, J=4.4,12.1 \mathrm{~Hz}$, 1H, H5'), 4.81 (dd, $\left.J=3.4,12.2 \mathrm{~Hz}, 1 \mathrm{H}, \mathrm{H} 5^{\prime \prime}\right), 5.30-5.32\left(\mathrm{~m}, 1 \mathrm{H}, \mathrm{H} 3^{\prime}\right), 5.58$ (d, $J=7.6 \mathrm{~Hz}$, 1H, H5), 6.64-6.66 (m, 1H, H1'), 7.30-7.34 (m, 3H, H6, Ts), 7.39-7.51 (m, 4H, Ar), 7.527.67 (m, 2H, Ar), 7.98-8.10 (m, 4H, Ar). ${ }^{13} \mathrm{C}$ NMR $\delta$ 21.72, 22.77, 26.77, 28.82, 28.99, 29.00, 29.08, 29.11 38.93, 41.01, 62.91 (C5'), 71.53 (dd, $J=17.2,35.4 \mathrm{~Hz}, \mathrm{C}^{\prime}$ ), 71.83, 77.36 (C4'), 84.01 (br s, C1'), 96.17 (C5), 120.90 (t, $J=263.1 \mathrm{~Hz}, \mathrm{C} 2$ '), 125.99, 128.72, $128.82,128.94,129.38,129.41,129.45,129.57,130.03,130.54,130.86,130.91,133.16$, 134.28, 134.35, 135.12, 135.24, 140.69 (C6), 146.42 (C4), 156.51, 164.39, 165.88, 166.99, 203.43. ${ }^{19} \mathrm{~F}$ NMR $\delta-120.69$ (br d, $\left.J=252.5 \mathrm{~Hz}, 1 \mathrm{~F}\right),-115.28(\mathrm{~d}, J=248.2 \mathrm{~Hz}, 1 \mathrm{~F})$.

\section{4- $N$-(11-Fluoro-10-oxoundecanyl)-3',5'-di-O-benzoyl-2'-deoxy-2',2'-}

difluorocytidine (74). To a solution of $\mathrm{KF}(2.8 \mathrm{mg}, 0.048 \mathrm{mmol}), \mathrm{K}_{2} \mathrm{CO}_{3}(6.5 \mathrm{mg}, 0.048$ mmol), Kryptofix 2.2.2 (17.9 mg, $0.048 \mathrm{mmol}$ ) in $\mathrm{CH}_{3} \mathrm{CN}(3 \mathrm{~mL}) \mathbf{7 3}$ (Ts derivative, 10 $\mathrm{mg}, 0.012 \mathrm{mmol}$ ) was stirred at $80{ }^{\circ} \mathrm{C}$. After $25 \mathrm{~min}$, the reaction mixture was quickly cooled in a water bath and filtered. The crude product was evaporated, and the resulting residue was column chromatographed (40\% EtOAc/hexane) to give $74(4.7 \mathrm{mg}, 60 \%)$ as a mixture of isomers. The major isomer had the following peaks: ${ }^{1} \mathrm{H}$ NMR $\left(\mathrm{CDCl}_{3}\right) \delta$ $1.22-1.35\left(\mathrm{~m}, 12 \mathrm{H}, 6 \times \mathrm{CH}_{2}\right), 1.54-1.56\left(\mathrm{~m}, 2 \mathrm{H}, \mathrm{CH}_{2}\right), 2.55\left(\mathrm{t}, J=7.3 \mathrm{~Hz}, 2 \mathrm{H}, \mathrm{CH}_{2}\right), 3.48-$ $3.50\left(\mathrm{~m}, 2 \mathrm{H}, \mathrm{CH}_{2}\right), 4.52-4.55\left(\mathrm{~m}, 1 \mathrm{H}, \mathrm{H} 4^{\prime}\right), 4.65$ (dd, $J=4.6,12.3 \mathrm{~Hz}, 1 \mathrm{H}, \mathrm{H} 5$ '), 4.79 (d, $J$ $\left.=47.7 \mathrm{~Hz}, 2 \mathrm{H}, \mathrm{CH}_{2}\right), 4.79(\mathrm{dd}, J=3.6,12.1 \mathrm{~Hz}, 1 \mathrm{H}, \mathrm{H} 5 "), 5.51(\mathrm{~d}, J=7.6 \mathrm{~Hz}, 1 \mathrm{H}, \mathrm{H} 5)$, $5.62\left(\mathrm{~m}, 1 \mathrm{H}, \mathrm{H} 3^{\prime}\right), 6.60-6.63\left(\mathrm{~m}, 1 \mathrm{H}, \mathrm{H} 1^{\prime}\right), 7.32$ (d, $\left.J=7.3,1 \mathrm{H}, \mathrm{H} 6\right), 7.41-7.55$ (m, 4H, Ar), 7.56-7.69 (m, 2H, Ar), 8.01-8.12 (m, 4H, Ar). ${ }^{13} \mathrm{C}$ NMR $\delta$ 22.72, 26.69, 28.68, 28.97, 29.06, 29.21, 29.85, 38.30, 38.32, 38.41, 44.03, $62.66\left(\mathrm{C}^{\prime}\right), 71.65(\mathrm{dd}, J=17.2,35.4 \mathrm{~Hz}$, C3'), 79.38 (C4'), 83.91 (br s, C1'), 85.04 (d, $J=185.2 \mathrm{~Hz}, \mathrm{CH}_{2} \mathrm{~F}$ ), 91.13 (C5), 120.67 (t, 
$\left.J=263.1 \mathrm{~Hz}, \mathrm{C} 2{ }^{\prime}\right), 127.62,128.89,128.98,129.12,129.85,130.31,133.77,133.45$, 134.39, 134.67, 137.68 (C6), $145.20(\mathrm{C} 4), 158.00,164.93,166.11,203.34 .{ }^{19} \mathrm{~F}$ NMR $\delta$ $227.42(\mathrm{t}, J=47.7,1 \mathrm{~F}),-120.37$ (br d, $J=217.9 \mathrm{~Hz}, 1 \mathrm{~F}),-115.21(\mathrm{dd}, J=245.1 \mathrm{~Hz}, 1 \mathrm{~F})$. HRMS (ESI+) $m / z$ calcd for $\mathrm{C}_{34} \mathrm{H}_{38} \mathrm{~F}_{3} \mathrm{~N}_{3} \mathrm{O}_{7}[\mathrm{M}+\mathrm{H}]+$, 658.2747; found, 658.2745.

4- $N$-(11-Fluoro-10-oxoundecanyl)-2'-deoxy-2',2'-difluorocytidine (76). Compound $74(20 \mathrm{mg}, .031 \mathrm{mmol})$ was dissolved in methanolic ammonia $(2 \mathrm{~mL})$ and stirred at ambient temperature. After $2 \mathrm{~h}$, volatiles were evaporated under reduced pressure, and the resulting residue was chromatographed $\left(5 \% \mathrm{MeOH} / \mathrm{CHCl}_{3}\right)$ to give $\mathbf{7 6}(7.5 \mathrm{mg}, 55 \%)$ as a clear oil. ${ }^{1} \mathrm{H}$ NMR (MeOD) $\delta 1.21-1.35\left(\mathrm{~m}, 12 \mathrm{H}, 6 \times \mathrm{CH}_{2}\right), 1.53 .1 .56\left(\mathrm{~m}, 2 \mathrm{H}, \mathrm{CH}_{2}\right), 2.41(\mathrm{t}, J=7.3$ $\left.\mathrm{Hz}, 2 \mathrm{H}, \mathrm{CH}_{2}\right), 3.35\left(\mathrm{t}, J=7.1 \mathrm{~Hz}, 2 \mathrm{H}, \mathrm{CH}_{2}\right), 3.74-3.76(\mathrm{~m}, 1 \mathrm{H}, \mathrm{H} 5), 3.90-3.92(\mathrm{~m}, 2 \mathrm{H}$, $\left.\mathrm{H}^{\prime}, 5^{\prime \prime}\right), 4.21-4.23\left(\mathrm{~m}, 1 \mathrm{H}, \mathrm{H}^{\prime}\right), 4.80\left(\mathrm{~d}, J=47.7 \mathrm{~Hz}, 2 \mathrm{H}, \mathrm{CH}_{2} \mathrm{~F}\right), 5.99$ (d, $J=7.9 \mathrm{~Hz}, 1 \mathrm{H}$, H5), 6.08-6.10 (m, 1H, H1'), 7.96 (d, $J=7.9,1 \mathrm{H}, \mathrm{H6}) .{ }^{13} \mathrm{C}$ NMR $\delta 23.88,27.94,29.94$, 30.17, 30.31, 30.72, 38.55, 41.70, $60.56\left(\mathrm{C}^{\prime}\right), 71.43$ (dd, $\left.J=17.1,35.4 \mathrm{~Hz}, \mathrm{C}^{\prime}\right), 82.22$ (C4'), 85.04 (d, $\left.J=185.2 \mathrm{~Hz}, \mathrm{CH}_{2} \mathrm{~F}\right), 87.96\left(\mathrm{Cl}^{\prime}\right), 97.36(\mathrm{C} 5), 124.00$ (t, $J=262.8 \mathrm{~Hz}$, C2'), 140.77 (C6), 158.29 (C2), 165.35 (C4), 202.21. ${ }^{19} \mathrm{~F}$ NMR $\delta-227.44(\mathrm{t}, J=47.7 \mathrm{~Hz}$, 1F), -120.15 (br s, 1F), -119.35 (dd, $J=4.1,12.7 \mathrm{~Hz}, 1 \mathrm{~F})$. HRMS (ESI+) $\mathrm{m} / z$ calcd for $\mathrm{C}_{20} \mathrm{H}_{30} \mathrm{~F}_{3} \mathrm{~N}_{3} \mathrm{O}_{5}[\mathrm{M}+\mathrm{H}]^{+}, 450.2210$; found, 450.2244 .

$N$-(10-undecenyl) benzamide (125). Benzoyl chloride $(0.670 \mathrm{~mL}, 0.810 \mathrm{~g}, 5.74$ $\mathrm{mmol})$ and $\mathrm{Et}_{3} \mathrm{~N}(1.5 \mathrm{~mL}, 1.09 \mathrm{~g}, 10.6 \mathrm{mmol})$ was added to a solution of $\mathbf{5 6}(0.810 \mathrm{~mL}$, $4.78 \mathrm{mmol})$ in $\mathrm{CH}_{2} \mathrm{Cl}_{2}(10 \mathrm{~mL})$ and stirred at ambient temperature. After $8 \mathrm{~h}$, the volatiles were evaporated under reduced pressure and the resulting residue was diluted with $\mathrm{CH}_{2} \mathrm{Cl}_{2}$ and partitioned with $\mathrm{HCl}(0.1 \mathrm{M})$ and $\mathrm{H}_{2} \mathrm{O}(15 \mathrm{~mL})$. The organic layer was washed with saturated $\mathrm{NaHCO}_{3} / \mathrm{H}_{2} \mathrm{O}(20 \mathrm{~mL})$, and brine $(20 \mathrm{~mL})$, dried over $\mathrm{Na}_{2} \mathrm{SO}_{4}$, and the resulting 
mixture was then column chromatographed (25\% EtOAc/hexane) to give $\mathbf{1 2 5}(1.22 \mathrm{~g}$, $93 \%)$ as a white solid. ${ }^{1} \mathrm{H}$ NMR $\left(\mathrm{CDCl}_{3}\right) \delta 1.31-1.35\left(\mathrm{~m}, 10 \mathrm{H}, 5 \times \mathrm{CH}_{2}\right), 1.61-1.63(\mathrm{~m}, 4 \mathrm{H}$, $\left.2 \times \mathrm{CH}_{2}\right), 2.04\left(\mathrm{dd}, J=6.9,14.2 \mathrm{~Hz}, 2 \mathrm{H}, \mathrm{CH}_{2}\right), 3.45\left(\mathrm{t}, J=7.1 \mathrm{~Hz}, 2 \mathrm{H}, \mathrm{CH}_{2}\right), 4.97-4.99$ (m, 2H, $\mathrm{CH}_{2}$ ), 5.81 (ddt, $\left.J=6.7,10.2,16.9 \mathrm{~Hz}, 1 \mathrm{H}, \mathrm{CH}\right), 6.11$ (br s, $\left.1 \mathrm{H}, \mathrm{NH}\right), 7.44-7.46$ (m, 3H, Ar), 7.74-7.77 (m, 2H, Ar).

$N$-(10,11-Dihydroxyundecan-1-yl) benzamide (126). $5 \%$ mol of $\mathrm{OsO}_{4}(50 \mu \mathrm{L}$, cat. amount) and $N$-methylmorpholine- $N$-oxide $(87.8 \mathrm{mg}, 0.75 \mathrm{mmol})$ was added to a solution of $125(137 \mathrm{mg}, 0.50 \mathrm{mmol})$ in acetone $(2 \mathrm{~mL})$ and water $(0.2 \mathrm{~mL})$, and the mixture was stirred at $0{ }^{\circ} \mathrm{C}$ to ambient temperature under Nitrogen. After $4 \mathrm{~h}$, the reaction mixture was diluted with $\mathrm{CH}_{2} \mathrm{Cl}_{2}(20 \mathrm{~mL})$ and partitioned with $\mathrm{H}_{2} \mathrm{O}$. The organic layer was washed with saturated $\mathrm{NaHCO}_{3} / \mathrm{H}_{2} \mathrm{O}(15 \mathrm{~mL})$, and brine $(15 \mathrm{~mL})$, dried over $\mathrm{Na}_{2} \mathrm{SO}_{4}$, and evaporated, and the resulting residue was column chromatographed (75\% EtOAc/hexane) to give $\mathbf{1 2 6}$ (138 mg, $90 \%) .{ }^{1} \mathrm{H}$ NMR $\left(\mathrm{CDCl}_{3}\right) \delta 1.31-1.35\left(\mathrm{~m}, 16 \mathrm{H}, 8 \times \mathrm{CH}_{2}\right), 3.41(\mathrm{dd}, J=7.7,11.0$ $\mathrm{Hz}, 1 \mathrm{H}, \mathrm{CH}), 3.44\left(\mathrm{t}, J=7.1 \mathrm{~Hz}, 2 \mathrm{H}, \mathrm{CH}_{2}\right), 3.63(\mathrm{dd}, J=3.0,11.0 \mathrm{~Hz}, 1 \mathrm{H}, \mathrm{CH}), 3.68-3.70$ (m, 1H, CH), 6.13 (br s, 1H, NH), 7.44-7.46 (m, 3H, Ar), 7.74-7.77 (m, 2H, Ar).

$N$-(10,11-Dihydroxy-11-O-toluenesulfnonylundecanyl) benzamide (127). Tosyl chloride (65.1 $\mathrm{mg}, 0.33 \mathrm{mmol})$ was added to a solution of $\mathbf{1 2 6}(100 \mathrm{mg}, 0.33 \mathrm{mmol})$ in anhydrous $\mathrm{CH}_{2} \mathrm{Cl}_{2}(5 \mathrm{~mL})$ in the presence of $\mathrm{Et}_{3} \mathrm{~N}(65 \mu \mathrm{L}, 47 \mathrm{mg}, 0.50 \mathrm{mmol})$. The mixture was stirred at $40{ }^{\circ} \mathrm{C}$. After 18 hours, the reaction mixture was diluted with $\mathrm{CH}_{2} \mathrm{Cl}_{2}$ and partitioned with $\mathrm{HCl}(0.1 \mathrm{M})$ and $\mathrm{H}_{2} \mathrm{O}(15 \mathrm{~mL})$. The organic layer was washed with saturated $\mathrm{NaHCO}_{3} / \mathrm{H}_{2} \mathrm{O}(15 \mathrm{~mL})$, and brine $(15 \mathrm{~mL})$, dried over $\mathrm{Na}_{2} \mathrm{SO}_{4}$, and evaporated, and the resulting residue was column chromatographed (50\% EtOAc/hexane) to give $\mathbf{1 2 7}$ (91 mg, 60\%). ${ }^{1} \mathrm{H}$ NMR $\left(\mathrm{CDCl}_{3}\right) \delta 1.32-1.35\left(\mathrm{~m}, 14 \mathrm{H}, 7 \times \mathrm{CH}_{2}\right), 1.59-1.61\left(\mathrm{~m}, 2 \mathrm{H}, \mathrm{CH}_{2}\right)$, 
$2.45\left(\mathrm{~s}, 3 \mathrm{H}, \mathrm{CH}_{3}\right), 3.44\left(\mathrm{dd}, J=7.1,13.1 \mathrm{~Hz}, 2 \mathrm{H}, \mathrm{CH}_{2}\right), 3.82(\mathrm{dd}, J=2.8,7.0, \mathrm{~Hz}, 1 \mathrm{H}, \mathrm{CH})$, 3.87-3.89 (m, 1H, CH), 4.02 (dd, $J=2.8,9.8 \mathrm{~Hz}, 1 \mathrm{H}, \mathrm{CH}), 6.17$ (br s, 1H, NH), 7.35 (d, $J$ $=8.2 \mathrm{~Hz}, 2 \mathrm{H}, \mathrm{Ts}), 7.42(\mathrm{~d}, J=8.2 \mathrm{~Hz}, 2 \mathrm{H}, \mathrm{Ts}), 7.46-7.49(\mathrm{~m}, 1 \mathrm{H}, \mathrm{Ar}), 7.75-7.79(\mathrm{~m}, 4 \mathrm{H}$, $\operatorname{Ar})$.

$N$-(10-0xo,11- $O$-toluenesulfnonylundecanyl) benzamide (128). A freshly prepared solution of Collins reagent $\left[\mathrm{CrO}_{3}(52 \mathrm{mg}, 0.52 \mathrm{mmol})\right.$, pyridine $(8 \mu \mathrm{L}, 52 \mathrm{mg}, 0.52 \mathrm{mmol})$, and $\mathrm{Ac}_{2} \mathrm{O}(102 \mu \mathrm{L}, 107 \mathrm{mg}, 1.04 \mathrm{mmol})$ in $\left.\mathrm{CH}_{2} \mathrm{Cl}_{2}(2 \mathrm{~mL})\right]$ was added to a stirred solution of 127 (60 mg, $0.13 \mathrm{mmol})$ in $\mathrm{CH}_{2} \mathrm{Cl}_{2}(8 \mathrm{~mL})$ at ambient temperature. The resulting mixture was stirred for $1.5 \mathrm{~h}$. and was immediately column chromatographed (45\% EtOAc/hexane) to give 128 (56 mg, $94 \%) .{ }^{1} \mathrm{H}$ NMR $\left(\mathrm{CDCl}_{3}\right) \delta 1.29-1.32\left(\mathrm{~m}, 10 \mathrm{H}, 5 \times \mathrm{CH}_{2}\right), 1.57-1.59$ (m, 4H, $\left.2 \times \mathrm{CH}_{2}\right), 2.45\left(\mathrm{~s}, 3 \mathrm{H}, \mathrm{CH}_{3}\right), 2.48\left(\mathrm{t}, J=7.4 \mathrm{~Hz}, 2 \mathrm{H}, \mathrm{CH}_{2}\right), 3.44(\mathrm{dd}, J=7.1,13.1$ $\left.\mathrm{Hz}, 2 \mathrm{H}, \mathrm{CH}_{2}\right), 4.48\left(\mathrm{~s}, 2 \mathrm{H}, \mathrm{CH}_{2}\right), 6.15(\mathrm{br} \mathrm{s}, 1 \mathrm{H}, \mathrm{NH}), 7.36$ (d, $\left.J=8.2,2 \mathrm{H}, \mathrm{Ts}\right), 7.42$ (d, $J$ $=8.2,2 \mathrm{H}, \mathrm{Ts}), 7.46-7.49(\mathrm{~m}, 1 \mathrm{H}, \mathrm{Ar}), 7.75-7.79(\mathrm{~m}, 4 \mathrm{H}, \mathrm{Ar})$.

$\boldsymbol{N}$-(10-oxo,11-O-Fluoroundecanyl) benzamide (75). To a solution of KF (26 mg, 0.44 mmol), $\mathrm{K}_{2} \mathrm{CO}_{3}(60 \mathrm{mg}, 0.44 \mathrm{mmol}), 18-C r o w n-6$ (163 mg, $\left.0.44 \mathrm{mmol}\right)$ in $\mathrm{CH}_{3} \mathrm{CN}(6 \mathrm{~mL})$, $128(50 \mathrm{mg}, 0.11 \mathrm{mmol})$ was stirred at $75^{\circ} \mathrm{C}$. After $25 \mathrm{~min}$, the reaction mixture was quickly cooled in a water bath and filtered. The crude product was evaporated, and the resulting residue was column chromatographed (40\% EtOAc/hexane) to give 75 (20 mg, 58\%). ${ }^{1} \mathrm{H}$ $\operatorname{NMR}\left(\mathrm{CDCl}_{3}\right) \delta 1.29-1.32\left(\mathrm{~m}, 10 \mathrm{H}, 5 \times \mathrm{CH}_{2}\right), 1.59-1.62\left(\mathrm{~m}, 4 \mathrm{H}, 2 \times \mathrm{CH}_{2}\right), 2.53(\mathrm{t}, J=7.4$ $\left.\mathrm{Hz}, 2 \mathrm{H}, \mathrm{CH}_{2}\right), 3.45\left(\mathrm{dd}, J=7.1,13.1 \mathrm{~Hz}, 2 \mathrm{H}, \mathrm{CH}_{2}\right), 4.79\left(\mathrm{~d}, J=47.7 \mathrm{~Hz}, 2 \mathrm{H}, \mathrm{CH}_{2} \mathrm{~F}\right), 6.09$ (br s, $1 \mathrm{H}, \mathrm{NH}), 7.46-7.49(\mathrm{~m}, 3 \mathrm{H}, \mathrm{Ar}), 7.74-7.77(\mathrm{~m}, 2 \mathrm{H}, \mathrm{Ar}) .{ }^{19} \mathrm{~F}$ NMR $\delta-227.48(\mathrm{t}, J=$ 47.7, 1F). 


\subsection{Synthesis of 4- $N$-alkanoyl and 4- $N$-alkyl clickable gemcitabine analogues with silicon-fluoride acceptors}

Methyl 11-azidoundecanoate (79). Sodium azide (175 mg, $2.7 \mathrm{mmol}$ ) was added to a stirred solution of methyl 11-bromoundecanoate $\mathbf{7 8}(500 \mathrm{mg}, 1.8 \mathrm{mmol})$ in DMF. After 3 hours, the crude mixture was diluted with water and extracted with $\mathrm{Et}_{2} \mathrm{O}$. The organic layer was then washed with brine, dried over $\mathrm{Na}_{2} \mathrm{SO}_{4}$ and evaporated under reduced pressure to give $7^{147}$ (420 mg, 97\%). ${ }^{1} \mathrm{H}$ NMR (400 MHz, $\left.\mathrm{CDCl}_{3}\right) \delta 1.30(\mathrm{~s}, 12 \mathrm{H}), 1.49-1.66(\mathrm{~m}, 4 \mathrm{H})$, $2.29(\mathrm{t}, J=7.5 \mathrm{~Hz}, 2 \mathrm{H}), 3.24(\mathrm{t}, J=7.0 \mathrm{~Hz}, 2 \mathrm{H}), 3.65(\mathrm{~s}, 3 \mathrm{H})$.

11-Azidoundecanoic acid (80). $\mathrm{NaOH}(1 \mathrm{M}, 1.5 \mathrm{~mL})$ was added to a solution of 79 (400 mg, $1.7 \mathrm{mmol})$ in $\mathrm{MeOH}(1 \mathrm{~mL})$ and stirred at ambient temperature. After $2 \mathrm{~h}$, the reaction mixture was diluted with water and was extracted with $\mathrm{Et}_{2} \mathrm{O}$ to remove any unreacted starting material. The aqueous layer was then acidified with $\mathrm{HCl}(1 \mathrm{M})$ and extracted with fresh portions of $\mathrm{Et}_{2} \mathrm{O}(2 \times 10 \mathrm{~mL})$. The combined organic layer was then washed with brine, dried over $\mathrm{Na}_{2} \mathrm{SO}_{4}$ and evaporated under reduced pressure to give $\mathbf{8 0}^{147}$ (350 mg, 88\%). ${ }^{1} \mathrm{H}$ NMR (400 MHz, $\left.\mathrm{CDCl}_{3}\right) \delta 1.32(\mathrm{~s}, 12 \mathrm{H}), 1.51-1.71(\mathrm{~m}, 4 \mathrm{H}), 2.35(\mathrm{t}, J$ $=7.5 \mathrm{~Hz}, 2 \mathrm{H}), 3.25(\mathrm{t}, J=7.0 \mathrm{~Hz}, 2 \mathrm{H})$.

\section{4-N-(11-Azidoundecanoyl)-2'-deoxy-2'， $\quad \mathbf{2}^{\prime}$-difluorocytidine $\quad$ (81). $\quad N, N-$} Diisopropylethylamine ( $35 \mu \mathrm{L}, 0.2 \mathrm{mmol}$ ), 1-hydroxybenzotriazole ( $27 \mathrm{mg}, 0.2 \mathrm{mmol}), 80$ (46 mg, $0.2 \mathrm{mmol}$ ), and 1-ethyl-3-(3-dimethylaminopropyl)carbodiimide (45 $\mu \mathrm{L}, 0.2$ mmol) were sequentially added to a stirred solution of gemcitabine hydrochloride (50 $\mathrm{mg}$, $0.17 \mathrm{mmol})$ in DMF (4 mL) at ambient temperature under Nitrogen. The reaction mixture was then gradually heated to $65^{\circ} \mathrm{C}$ (oil-bath) and was kept stirring overnight. The crude mixture was evaporated and column chromatographed $\left(0 \rightarrow 10 \% \mathrm{MeOH} / \mathrm{CHCl}_{3}\right)$ to give 
81 (56 mg, 70\%): UV (CH3 $\left.\mathrm{CH}_{3} \mathrm{OH}\right) \lambda \max 299 \mathrm{~nm}(\varepsilon 6500), \lambda \min 250 \mathrm{~nm}(\varepsilon 12900) ;{ }^{1} \mathrm{H}$ $\operatorname{NMR}\left(\mathrm{CD}_{3} \mathrm{OD}\right) \delta 1.24-1.47\left(\mathrm{~m}, 12 \mathrm{H}, 6 \times \mathrm{CH}_{2}\right), 1.51-1.75\left(\mathrm{~m}, 4 \mathrm{H}, 2 \times \mathrm{CH}_{2}\right), 2.45(\mathrm{t}, J=$ $7.4 \mathrm{~Hz}, 2 \mathrm{H}, \mathrm{CH}_{2}$ ), 3.27 (t, $J=6.9 \mathrm{~Hz}, 2 \mathrm{H}, \mathrm{CH}_{2}$ ), 3.81 (dd, $J=2.8,12.4 \mathrm{~Hz}, 1 \mathrm{H}, \mathrm{H} 5^{\prime}$ ), 3.89-4.05 (m, 2H, H5', H4'), 4.30 (td, $J=8.5,12.2 \mathrm{~Hz}, 1 \mathrm{H}, \mathrm{H} 3$ '), 6.17-6.35 (m, 1H, H1'), $7.50(\mathrm{~d}, J=7.6 \mathrm{~Hz}, 1 \mathrm{H}, \mathrm{H} 5), 8.34(\mathrm{~d}, J=7.6 \mathrm{~Hz}, 1 \mathrm{H}, \mathrm{H6}) ;{ }^{13} \mathrm{C}$ NMR $\delta 25.92,27.80,29.90$, 30.11, 30.20, 30.33, 30.41, 30.50, 38.17, 52.47, $60.30\left(\mathrm{C5}^{\prime}\right), 70.27$ (dd, $J=22.2,23.6 \mathrm{~Hz}$, C3'), $82.92(\mathrm{~d}, J=8.6 \mathrm{~Hz}, \mathrm{C} 4$ '), 86.42 (dd, $J=26.6,37.6 \mathrm{~Hz}, \mathrm{C} 1), 98.25$ (C5), 120.87 (t, $J$ $=259.9 \mathrm{~Hz}, \mathrm{C} 2$ '), $145.96(\mathrm{C} 6), 157.68(\mathrm{C} 2), 164.83(\mathrm{C} 4), 176.00(\mathrm{CO}) ;{ }^{19} \mathrm{~F}$ NMR $\delta$-120.05 (d of $\mathrm{m}, J=239.7 \mathrm{~Hz}, 1 \mathrm{~F}),-119.10(\mathrm{~d}$ of $\mathrm{m}, J=240.1 \mathrm{~Hz}, 1 \mathrm{~F})$. HRMS (ESI+) $\mathrm{m} / z$ calcd for $\mathrm{C}_{20} \mathrm{H}_{30} \mathrm{~F}_{2} \mathrm{~N}_{6} \mathrm{O}_{5}[\mathrm{M}+\mathrm{Na}]^{+}$495.2146; found 495.2141.

4-N-(5-Hexynoyl)-2'-deoxy-2', 2'-difluorocytidine (82). Trimethylsilyl chloride (250 $\mu \mathrm{L}, 2 \mathrm{mmol}$ ) was added to a solution of gemcitabine hydrochloride (200 $\mathrm{mg}, 0.7 \mathrm{mmol})$ in $\mathrm{CH}_{3} \mathrm{CN}(2 \mathrm{~mL})$ and pyridine $(3 \mathrm{~mL})$ at $0{ }^{\circ} \mathrm{C}$. The mixture was stirred for $4 \mathrm{~h}$ from $0{ }^{\circ} \mathrm{C}$ to room temperature. A solution of commercially available 5-hexynoic acid $(230 \mu \mathrm{L}, 2.1$ mmol) in $\mathrm{CH}_{3} \mathrm{CN}(2 \mathrm{~mL})$, previously activated by $\mathrm{EDC}(50 \mu \mathrm{L}, 1 \mathrm{mmol})$, was added to the reaction mixture, which was heated at $60^{\circ} \mathrm{C}$ for 18 hours. After the solution was cooled down to room temperature, ethanol $(5 \mathrm{~mL})$ was added and the mixture was heated at $45{ }^{\circ} \mathrm{C}$ for $4 \mathrm{~h}$. After evaporation under vacuum, the resulting residue was column chromatographed $\left(80 \rightarrow 100 \%\right.$ EtOAc/hexane) to give $\mathbf{8 2}^{45}(157.6 \mathrm{mg}, 63 \%):{ }^{1} \mathrm{H}$ NMR $\left(\mathrm{CD}_{3} \mathrm{OD}\right) \delta$ 1.83-1.86 (m, 2H, CH$)_{2}, 2.25-2.28\left(\mathrm{~m}, 3 \mathrm{H}, \mathrm{CH}_{2}, \mathrm{CH}\right), 2.60(\mathrm{t}, J=7.3 \mathrm{~Hz}, 2 \mathrm{H}$, $\mathrm{CH}_{2}$ ), 3.82-3.84 (m, 1H, H5'), 3.89-4.07 (m, 2H, H5", H4'), 4.31 (dd, $J=12.1,20.6 \mathrm{~Hz}$, 1H, H3'), 6.24-6.26 (m, 1H, H1'), 7.49 (d, $J=7.6 \mathrm{~Hz}, 1 \mathrm{H}, \mathrm{H} 5), 8.34$ (d, $J=7.6 \mathrm{~Hz}, 1 \mathrm{H}$, H6); ${ }^{13} \mathrm{C}$ NMR $\delta 18.42,24.96,33.47,60.50\left(\mathrm{C}^{\prime}\right), 68.14(\mathrm{CH}), 70.20$ (C) $70.34(\mathrm{t}, J=23.1$ 
Hz, C3'), 82.35 (d, $\left.J=8.6 \mathrm{~Hz}, \mathrm{C}^{\prime}\right), 86.1$ (dd, $\left.J=26.6,38.3 \mathrm{~Hz}, \mathrm{C} 1^{\prime}\right), 96.30\left(\mathrm{C}^{\prime}\right.$ '), 123.91 (t, $J=259.3 \mathrm{~Hz}, \mathrm{C} 2$ ) $), 142.51(\mathrm{C} 6), 157.78(\mathrm{C} 2), 167.74(\mathrm{C} 4), 175.97(\mathrm{CO}) ;{ }^{19} \mathrm{~F}$ NMR $\delta$ 120.14 (d of $\mathrm{m}, J=244.4 \mathrm{~Hz}, 1 \mathrm{~F}),-119.23$ (d of $\mathrm{m}, J=243.6 \mathrm{~Hz}, 1 \mathrm{~F})$.

7-Azido-1-aminoheptane (85). Step A. Sodium azide (272 mg, $4.0 \mathrm{mmol})$ was added to a stirred solution of the 1,7-dibromoheptane $83(424 \mathrm{mg}, 1.6 \mathrm{mmol})$ in DMF at $60{ }^{\circ} \mathrm{C}$ (oil bath). After $6 \mathrm{~h}$, the crude mixture was diluted with water and extracted with $\mathrm{Et}_{2} \mathrm{O}$. The organic layer was then washed with brine, dried over $\mathrm{Na}_{2} \mathrm{SO}_{4}$ and evaporated under reduced pressure to give 1,7-diazidoheptane $\mathbf{8 4}$ which was used immediately in next step.

Step B. To a solution of 1,7-diazidoheptane 84 (182 mg, $1 \mathrm{mmol})$ in $\mathrm{Et}_{2} \mathrm{O}(1 \mathrm{~mL})$, ethyl acetate $(1 \mathrm{~mL})$ and $5 \%$ aqueous $\mathrm{HCl}(3 \mathrm{~mL})$ was added $\mathrm{Ph}_{3} \mathrm{P}(256 \mathrm{mg}, 0.98 \mathrm{mmol})$ portion wise over $1 \mathrm{~h}$ and stirred for $16 \mathrm{~h}$ at ambient temperature. The organic layer was discarded and the aqueous layer was washed with $(2 \times 10 \mathrm{~mL}) \mathrm{CH}_{2} \mathrm{Cl}_{2}$. The resultant aqueous phase was basified with sodium hydroxide ( $\mathrm{pH}>12)$, and then extracted with $(3 \times 6 \mathrm{~mL}) \mathrm{CH}_{2} \mathrm{Cl}_{2}$. The combined extracts were dried over $\mathrm{Na}_{2} \mathrm{SO}_{4}$, filtered and evaporated under reduced pressure to give $\mathbf{8 5}^{148}(130 \mathrm{mg}, 83 \%):{ }^{1} \mathrm{H}$ NMR $\left(\mathrm{CDCl}_{3}\right) \delta$ 1.26-1.48 (m, 10H), 1.57-1.59 (m, 2H), $2.66\left(\mathrm{t}, J=7.0 \mathrm{~Hz}, 2 \mathrm{H}, \mathrm{CH}_{2}\right), 3.22\left(\mathrm{t}, J=6.9 \mathrm{~Hz}, 2 \mathrm{H}, \mathrm{CH}_{2}\right)$.

4-N-(7-Azidoheptanyl)-2'-deoxy-2', 2'-difluorocytidine (86). Freshly prepared 7Azido-1-aminoheptane 85 (112.5 mg, $0.72 \mathrm{mmol})$ was added to a suspension of 62 (100 $\mathrm{mg}, 0.24 \mathrm{mmol})$ in 1,4-dioxane $(5 \mathrm{~mL})$ and $\mathrm{Et}_{3} \mathrm{~N}(0.10 \mathrm{~mL}, 63 \mathrm{mg}, 0.72 \mathrm{mmol})$ and the mixture was left stirring at $65^{\circ} \mathrm{C}$. After $24 \mathrm{~h}$, volatiles were evaporated and the resulting residue was column chromatographed ( $\left.5 \% \mathrm{MeOH} / \mathrm{CHCl}_{3}\right)$ to give $\mathbf{8 6}$ (238 $\left.\mathrm{mg}, 82 \%\right)$ : UV $\left(\mathrm{CH}_{3} \mathrm{OH}\right) \lambda \max 267 \mathrm{~nm}(\varepsilon 8200), \lambda \min 227 \mathrm{~nm}(\varepsilon 7400) ;{ }^{1} \mathrm{H}$ NMR $\left(\mathrm{CD}_{3} \mathrm{OD}\right) \delta 1.31-1.41$ (m, 12H, $\left.6 \times \mathrm{CH}_{2}\right), 1.51-1.70\left(\mathrm{~m}, 4 \mathrm{H}, 2 \times \mathrm{CH}_{2}\right), 3.25\left(\mathrm{t}, J=6.9 \mathrm{~Hz}, 2 \mathrm{H}, \mathrm{CH}_{2}\right), 3.45(\mathrm{t}, J$ 
$\left.=7.0,2 \mathrm{H}, \mathrm{CH}_{2}\right) 3.77-3.83\left(\mathrm{~m}, 1 \mathrm{H}, \mathrm{H} 5^{\prime}\right), 3.91-3.99\left(\mathrm{~m}, 2 \mathrm{H}, \mathrm{H} 5^{\prime}, \mathrm{H} 4^{\prime}\right), 4.25(\mathrm{dt}, J=10.5$, $\left.20.8 \mathrm{~Hz}, 1 \mathrm{H}, \mathrm{H3} 3^{\prime}\right), 5.85$ (d, $\left.J=7.6 \mathrm{~Hz}, 1 \mathrm{H}, \mathrm{H} 5\right), 6.23-6.25\left(\mathrm{~m}, 1 \mathrm{H}, \mathrm{H} 1^{\prime}\right), 7.71(\mathrm{~d}, J=7.6$ $\mathrm{Hz}, 1 \mathrm{H}, \mathrm{H6}) ;{ }^{13} \mathrm{C}$ NMR $\delta 27.75,27.86,29.84,29.88,29.92,41.65,52.45,60.56$ (C5'), 70.66 (t, $J=23.1 \mathrm{~Hz}, \mathrm{C}^{\prime}$ ), $82.22\left(\mathrm{~d}, J=8.6 \mathrm{~Hz}, \mathrm{C} 4{ }^{\prime}\right), 86.26$ (dd, $\left.J=26.6,38.3 \mathrm{~Hz}, \mathrm{Cl}^{\prime}\right), 97.32$ (C5), 124.02 (t, $J=259.2 \mathrm{~Hz}, \mathrm{C} 2$ '), $140.80(\mathrm{C} 6), 158.29(\mathrm{C} 2), 165.38(\mathrm{C} 4) ;{ }^{19} \mathrm{~F}$ NMR $\delta$ 119.86 (d of $\mathrm{m}, J=246.2 \mathrm{~Hz}, 1 \mathrm{~F}$ ), -119.89 (d of $\mathrm{m}, J=240.2 \mathrm{~Hz}, 1 \mathrm{~F}$ ). HRMS (ESI+) $\mathrm{m} / z$ calcd for $\mathrm{C}_{16} \mathrm{H}_{24} \mathrm{~F}_{2} \mathrm{~N}_{6} \mathrm{O}_{4}[\mathrm{M}+\mathrm{H}]^{+}$403.1902; found 403.1913.

4-(Azidomethyl)phenyldiisopropylsilane (88). Step A. Methanesulfonyl chloride (39 $\mu \mathrm{L}, 0.4 \mathrm{mmol}$ ) was added to a stirred solution of 4-(di-iso-propylsilyl)benzylalcohol 87 (100 mg, $0.4 \mathrm{mmol})$ and triethylamine $(110 \mu \mathrm{L}, 81 \mathrm{mg}, 0.8 \mathrm{mmol})$ in $\mathrm{CH}_{2} \mathrm{Cl}_{2}(5 \mathrm{~mL})$ at 0 ${ }^{\circ} \mathrm{C}$ under $\mathrm{N}_{2}$ atmosphere. After stirring for $5 \mathrm{~min}$, the resulting mixture was allowed to warm up to ambient temperature and kept stirring for $1 \mathrm{~h}$. The reaction mixture was then diluted with $\mathrm{CH}_{2} \mathrm{Cl}_{2}(15 \mathrm{~mL})$ and partitioned between $\mathrm{H}_{2} \mathrm{O}(20 \mathrm{~mL})$ and the aqueous layer extracted with fresh portions of $\mathrm{CH}_{2} \mathrm{Cl}_{2}(2 \times 20 \mathrm{~mL})$. The combined organic layer was then washed with brine $(20 \mathrm{~mL})$, dried over $\mathrm{Na}_{2} \mathrm{SO}_{4}$ and evaporated under reduced pressure to give 4-(O-mesylmethyl)phenyldiisopropylsilane (91\%) of sufficient purity to use directly in next step: ${ }^{1} \mathrm{H}$ NMR $\left(400 \mathrm{MHz}, \mathrm{CDCl}_{3}\right) \delta 0.99(\mathrm{~d}, J=7.3 \mathrm{~Hz}, 6 \mathrm{H}), 1.05(\mathrm{~d}, J=7.3 \mathrm{~Hz}$, $6 \mathrm{H}), 1.21-1.30(\mathrm{~m}, 2 \mathrm{H}), 2.92(\mathrm{~s}, 3 \mathrm{H}), 3.94(\mathrm{t}, J=3.1 \mathrm{~Hz}, 1 \mathrm{H}), 5.24(\mathrm{~s}, 2 \mathrm{H}), 7.35(\mathrm{~d}, J=$ $7.7 \mathrm{~Hz}, 2 \mathrm{H}), 7.45(\mathrm{~d}, J=7.9 \mathrm{~Hz}, 2 \mathrm{H})$.

Step B. Sodium azide (34 $\mathrm{mg}, 0.5 \mathrm{mmol})$ was added to a stirred solution of the 4- $(O-$ mesylmethyl)phenyldiisopropylsilane (105 $\mathrm{mg}, 0.3 \mathrm{mmol}$ ) in DMF. After $6 \mathrm{~h}$, the crude mixture was diluted with water and extracted with $\mathrm{Et}_{2} \mathrm{O}$. The organic layer was then washed with brine, dried over $\mathrm{Na}_{2} \mathrm{SO}_{4}$ and evaporated under reduced pressure. The resulting 
residue was column chromatographed (20\% EtOAc/hexanes) to give $\mathbf{8 8}^{149}$ (118 mg, 95\%). ${ }^{1} \mathrm{H}$ NMR (400 MHz, $\left.\mathrm{CDCl}_{3}\right) \delta 0.99(\mathrm{~d}, J=7.3 \mathrm{~Hz}, 6 \mathrm{H}), 1.07(\mathrm{~d}, J=7.3 \mathrm{~Hz}, 6 \mathrm{H}), 1.20-1.28$ $(\mathrm{m}, 2 \mathrm{H}), 3.96(\mathrm{t}, J=3.1 \mathrm{~Hz}, 1 \mathrm{H}), 4.36(\mathrm{~s}, 2 \mathrm{H}), 7.30(\mathrm{~d}, J=7.7 \mathrm{~Hz}, 2 \mathrm{H}), 7.54(\mathrm{~d}, J=7.9$ $\mathrm{Hz}, 2 \mathrm{H})$.

Diisopropyl(4-((prop-2-yn-1-yloxy)methyl)phenyl)silane $\quad$ (89). 4-(Di-isopropylsilyl)benzylalcohol 87 (100 mg, $0.4 \mathrm{mmol}$ ) was added to a stirred solution of sodium hydride ( $11.5 \mathrm{mg}, 0.48 \mathrm{mmol}$ ) in dry THF. After stiring for $2 \mathrm{~h}$ at $65^{\circ} \mathrm{C}$, propargyl bromide (80\% weight in toluene, $89 \mu \mathrm{L}, 0.8 \mathrm{mmol}$ ) was added to the reaction mixture. The stirred solution was stirred at $65{ }^{\circ} \mathrm{C}$ overnight. The reaction mixture was cooled at room temperature and extracted with $\mathrm{Et}_{2} \mathrm{O}(20 \mathrm{~mL})$. The organic layer was then washed with brine, dried over $\mathrm{Na}_{2} \mathrm{SO}_{4}$ and evaporated under reduced pressure. The resulting residue was column chromatographed (20\% EtOAc/hexanes) to give $\mathbf{8 9}$ as an oil $(85 \mathrm{mg}, 82 \%) .{ }^{1} \mathrm{H}$ NMR (400 MHz, $\left.\mathrm{CDCl}_{3}\right) \delta 0.98(\mathrm{~d}, J=7.3 \mathrm{~Hz}, 6 \mathrm{H}), 1.06(\mathrm{~d}, J=7.3 \mathrm{~Hz}, 6 \mathrm{H}), 1.18-1.26$ $(\mathrm{m}, 2 \mathrm{H}), 2.47(\mathrm{t}, J=2.3 \mathrm{~Hz}, 1 \mathrm{H}), 3.94(\mathrm{t}, J=3.1 \mathrm{~Hz}, 1 \mathrm{H}), 4.20(\mathrm{~d}, J=2.4 \mathrm{~Hz}, 2 \mathrm{H}), 4.61(\mathrm{~s}$, 2H), $7.35(\mathrm{~d}, J=7.7 \mathrm{~Hz}, 2 \mathrm{H}), 7.51(\mathrm{~d}, J=7.8 \mathrm{~Hz}, 2 \mathrm{H}) ;{ }^{13} \mathrm{C}$ NMR $\delta 10.69,18.45,18.64$, $57.30,71.62,74.65,79.67,127.32,134.87,135.65,138.14$.

\section{Synthesis of silicon-fluoride acceptors: General procedure for the click reactions}

Sodium ascorbate $(0.02 \mathrm{mmol})$, copper sulfate $(0.02 \mathrm{mmol})$ modified nucleoside $(0.1$ $\mathrm{mmol})$ and silane $(0.1 \mathrm{mmol})$ were suspended in a mixture of tert-butanol/water $(3: 1(\mathrm{v} / \mathrm{v})$, $3 \mathrm{~mL}$ ). The reaction mixture was left at room temperature for 1-6 hours. The reaction mixture was extracted with $\mathrm{CHCl}_{3}(10 \mathrm{~mL})$. The organic layer was washed with sat $\mathrm{NH}_{4} \mathrm{Cl}$ $(10 \mathrm{~mL})$, brine $(10 \mathrm{~mL})$, dried over $\mathrm{Na}_{2} \mathrm{SO}_{4}$, filtered and evaporated under reduced 
pressure. The crude product was purified by chromatography $\left(\mathrm{CHCl}_{3} / \mathrm{MeOH} 95: 5\right)$ to afford the desired triazole adducts:

\section{4- $N$-[11-Undecanoyl-(diisopropylsilyl)- $O$-propargylbenzyltriazol)]-2'-deoxy-2',}

2'difluorocytidine (90). Treatment of $\mathbf{8 1}(30 \mathrm{mg}, 0.06 \mathrm{mmol})$ with $\mathbf{8 9}(15.6 \mathrm{mg}, 0.06$ mmol) using procedure reported in section gave $90(40.5 \mathrm{mg}, 92 \%)$. $\mathrm{UV}\left(\mathrm{CH}_{3} \mathrm{OH}\right) \lambda \max$ $299 \mathrm{~nm}\left(\varepsilon\right.$ 6500), $250 \mathrm{~nm}\left(\varepsilon\right.$ 12900), $\lambda \min 278 \mathrm{~nm}\left(\varepsilon\right.$ 3800); ${ }^{1} \mathrm{H}$ NMR $\left(\mathrm{CD}_{3} \mathrm{OD}\right) \delta 0.96(\mathrm{~d}$, $J=7.3 \mathrm{~Hz}, 6 \mathrm{H}, i \mathrm{Pr}), 1.05(\mathrm{~d}, J=7.3 \mathrm{~Hz}, 6 \mathrm{H}, i \mathrm{Pr}), 1.24-1.47\left(\mathrm{~m}, 12 \mathrm{H}, 6 \times \mathrm{CH}_{2}\right), 1.51-1.75$ (m, 4H, $\left.2 \times \mathrm{CH}_{2}\right), 2.38\left(\mathrm{t}, J=7.3 \mathrm{~Hz}, 2 \mathrm{H}, \mathrm{CH}_{2}\right), 3.81\left(\mathrm{dd}, J=2.8,12.4 \mathrm{~Hz}, 1 \mathrm{H}, \mathrm{H} 5^{\prime}\right)$, 3.89-3.96 (m, 3H, H5', H4', Si-H), 4.30 (td, $J=8.5,12.2 \mathrm{~Hz}, 1 \mathrm{H}, \mathrm{H3}$ '), 4.33 (t, $J=7.1 \mathrm{~Hz}$, 2H), 4.55 (s, 2H, CH2), 4.61 (s, 2H, CH2), 6.19 (t, $\left.J=7.5,1 \mathrm{H}, \mathrm{H} 1^{\prime}\right), 7.33-7.35(\mathrm{~m}, 3 \mathrm{H}$, H5, Ar), $7.51\left(\mathrm{~d}, J=8.0 \mathrm{~Hz}, 2 \mathrm{H}\right.$. Ar), $7.74(\mathrm{~s}, 1 \mathrm{H}), 8.10(\mathrm{~d}, J=7.6 \mathrm{~Hz}, 1 \mathrm{H}, \mathrm{H} 6) ;{ }^{13} \mathrm{C} \mathrm{NMR}$ $\delta 25.92,27.80,29.90,30.11,30.20,30.33,30.41,30.50,38.17,52.47,60.30\left(\mathrm{C}^{\prime}\right), 70.27$ (dd, $\left.J=22.2,23.6 \mathrm{~Hz}, \mathrm{C} 3^{\prime}\right), 82.92(\mathrm{~d}, J=8.6 \mathrm{~Hz}, \mathrm{C} 4$ '), $86.42(\mathrm{dd}, J=26.6,37.6 \mathrm{~Hz}, \mathrm{C} 1)$, 98.25 (C5), 120.87 (t, $J=259.9$ Hz, C2'), 145.96 (C6), 157.68 (C2), 164.83 (C4), 176.00 (CO); ${ }^{19} \mathrm{~F}$ NMR $\delta-120.09$ (d of m, $J=239.2 \mathrm{~Hz}, 1 \mathrm{~F}$ ), -119.13 (d of $\mathrm{m}, J=240.2 \mathrm{~Hz}, 1 \mathrm{~F}$ ). HRMS (ESI+) $m / z$ calcd for $\mathrm{C}_{36} \mathrm{H}_{54} \mathrm{~F}_{2} \mathrm{~N}_{6} \mathrm{O}_{6} \mathrm{Si}[\mathrm{M}+\mathrm{Na}]^{+}$755.3738; found 755.3731.

\section{4- $N$-[6-Hexynoyl-(diisopropylsilyl)-O-propargylbenzyltriazol)]-2'-deoxy-2',}

2'difluorocytidine (91). Treatment of $\mathbf{8 2}$ (35 mg, $0.1 \mathrm{mmol})$ with $\mathbf{8 8}$ (24.7 mg, $0.1 \mathrm{mmol})$ using procedure reported in section gave $91(52.6 \mathrm{mg}, 87 \%)$. $\mathrm{UV}\left(\mathrm{CH}_{3} \mathrm{OH}\right) \lambda \max 299 \mathrm{~nm}$ (ع 6700), $248 \mathrm{~nm}\left(\varepsilon\right.$ 13000); ${ }^{1} \mathrm{H}$ NMR $\left(\mathrm{CD}_{3} \mathrm{OD}\right) \delta 0.96(\mathrm{~d}, J=7.3 \mathrm{~Hz}, 6 \mathrm{H}, i \mathrm{Pr}), 1.03(\mathrm{~d}, J$ $=7.3 \mathrm{~Hz}, 6 \mathrm{H}, i \operatorname{Pr}), 1.18-1.20\left(\mathrm{~m}, 4 \mathrm{H}, 2 \times \mathrm{CH}_{2}\right), 2.46\left(\mathrm{t}, J=7.3 \mathrm{~Hz}, 2 \mathrm{H}, \mathrm{CH}_{2}\right) .2 .71(\mathrm{t}, J=$ $7.4 \mathrm{~Hz}, 2 \mathrm{H}, \mathrm{CH}_{2}$ ), 3.74-3.76 (m, 1H, H5'), 3.89-3.95 (m, 3H, H5', H4', Si-H), 4.24-4.26 (m, 1H, H3'), $5.50\left(\mathrm{~s}, 2 \mathrm{H}, \mathrm{CH}_{2}\right), 6.19\left(\mathrm{t}, J=7.5 \mathrm{~Hz}, 1 \mathrm{H}, \mathrm{H1} 1^{\prime}\right), 7.28(\mathrm{~d}, J=8.0 \mathrm{~Hz}, 2 \mathrm{H}$. Ar), 
$7.35(\mathrm{~d}, J=7.6 \mathrm{~Hz}, 1 \mathrm{H}, \mathrm{H} 5), 7.51(\mathrm{~d}, J=8.0 \mathrm{~Hz}, 2 \mathrm{H} . \mathrm{Ar}), 7.56(\mathrm{~s}, 1 \mathrm{H}), 8.10(\mathrm{~d}, J=7.6 \mathrm{~Hz}$, 1H, H6); ${ }^{13} \mathrm{C}$ NMR $\delta 11.18,18.65,18.83,24.96,25.17,37.04,54.09,59.93\left(\mathrm{C}^{\prime}\right), 69.68$ $(\mathrm{CH}), 70.34\left(\mathrm{t}, J=23.1 \mathrm{~Hz}, \mathrm{C}^{\prime}\right), 81.82\left(\mathrm{~d}, J=8.6 \mathrm{~Hz}, \mathrm{C} 4^{\prime}\right), 85.70(\mathrm{dd}, J=26.6,38.3 \mathrm{~Hz}$, C1'), 97.03 (C5'), 122.39 (t, $\left.J=259.3 \mathrm{~Hz}, \mathrm{C} 2^{\prime}\right), 128.07,134.96,136.86,138.11,145.43$ (C6), 148.04, 155.77 (C2), $163.85(\mathrm{C} 4), 174.28(\mathrm{CO}) ;{ }^{19} \mathrm{~F}$ NMR $\delta-120.10$ (d of $\mathrm{m}, J=$ $233.4 \mathrm{~Hz}, 1 \mathrm{~F}),-119.20(\mathrm{~d}$ of $\mathrm{m}, J=240.9 \mathrm{~Hz}, 1 \mathrm{~F}$ ). HRMS (ESI+) $\mathrm{m} / \mathrm{z}$ calcd for $\mathrm{C}_{28} \mathrm{H}_{38} \mathrm{~F}_{2} \mathrm{~N}_{6} \mathrm{O}_{5} \mathrm{Si}[\mathrm{M}+\mathrm{Na}]^{+}$627.2538; found 627.2522.

\section{4- $N$-[7-heptanyl-(diisopropylsilyl)-O-propargylbenzyltriazol)]-2'-deoxy-2',}

2'difluorocytidine (92). Treatment of $\mathbf{8 6}$ (40 mg, $0.1 \mathrm{mmol}$ ) with $\mathbf{8 9}$ (silane, $26.0 \mathrm{mg}$, $0.1 \mathrm{mmol})$ using procedure reported in section gave $92(59.6 \mathrm{mg}, 90 \%)$. $\mathrm{UV}\left(\mathrm{CH}_{3} \mathrm{OH}\right) \lambda$ $\max 267 \mathrm{~nm}(\varepsilon 8200), \lambda \min 228 \mathrm{~nm}(\varepsilon 7500) ;{ }^{1} \mathrm{H} \mathrm{NMR}\left(\mathrm{CD}_{3} \mathrm{OD}\right) \delta 0.99(\mathrm{~d}, J=7.3 \mathrm{~Hz}$, $6 \mathrm{H}, i \mathrm{Pr}), 1.05(\mathrm{~d}, J=7.3 \mathrm{~Hz}, 6 \mathrm{H}, i \mathrm{Pr}), 1.31-1.41\left(\mathrm{~m}, 12 \mathrm{H}, 6 \times \mathrm{CH}_{2}\right), 1.50-1.52(\mathrm{~m}, 2 \mathrm{H}$, $\mathrm{CH}_{2}$ ), 1.90-1.92 (m, 2H, $\mathrm{CH}_{2}$ ), 3.41-3.43 (m, 2H, $\mathrm{CH}_{2}$ ), 3.80-3.82 (m, 1H, H5'), 3.91-4.02 (m, 3H, H5', H4', Si-H), 4.41-4.45 (m, 3H, H3', $\mathrm{CH}_{2}$ ), 4.60 (s, 2H, $\mathrm{CH}_{2}$ ), 4.65 (s, 2H, $\mathrm{CH}_{2}$ ), $5.82(\mathrm{~d}, J=7.6 \mathrm{~Hz}, 1 \mathrm{H}, \mathrm{H} 5), 6.23-6.25\left(\mathrm{~m}, 1 \mathrm{H}, \mathrm{H1}{ }^{\prime}\right), 7.38$ (d, $\left.J=8.0 \mathrm{~Hz}, 2 \mathrm{H}, \mathrm{Ar}\right), 7.48$ (d, $J=8.0 \mathrm{~Hz}, 2 \mathrm{H}, \mathrm{Ar}), 7.71(\mathrm{~d}, J=7.6 \mathrm{~Hz}, 1 \mathrm{H}, \mathrm{H} 6), 7.99(\mathrm{~s}, 1 \mathrm{H}, \mathrm{CH}) ;{ }^{13} \mathrm{C}$ NMR $\delta 11.26$, 18.76, 18.96, 27.01, 27.34, 30.93, 40.97, 50.50, $60.31\left(\mathrm{C5}^{\prime}\right), 64.42,70.26$ (t, $J=23.1 \mathrm{~Hz}$, C3'), 72.37, 81.75 (d, $J=8.6 \mathrm{~Hz}, \mathrm{C} 4$ '), $84.92(\mathrm{dd}, J=26.6,38.3 \mathrm{~Hz}, \mathrm{C1}$ '), 95.97 (C5), $124.04(\mathrm{t}, J=259.3 \mathrm{~Hz}, \mathrm{C} 2$ '), 127.88, 133.36, 140.78, 135.56, 136.34, 138.84, 140.78 (C6), 141.02, $155.92(\mathrm{C} 2), 164.77(\mathrm{C} 4) ;{ }^{19} \mathrm{~F}$ NMR $\delta-119.86(\mathrm{~d}$ of $\mathrm{m}, J=246.2 \mathrm{~Hz}, 1 \mathrm{~F}),-119.89$ (d of $\mathrm{m}, J=240.2 \mathrm{~Hz}, 1 \mathrm{~F}$ ). HRMS (ESI+) $\mathrm{m} / \mathrm{z}$ calcd for $\mathrm{C}_{32} \mathrm{H}_{48} \mathrm{~F}_{2} \mathrm{~N}_{6} \mathrm{O}_{5} \mathrm{Si}[\mathrm{M}+\mathrm{Na}]^{+}$ 685.3322; found 685.3324. 


\section{General Procedure for Fluorination Reactions}

Solid KF (4.7 mg, $0.08 \mathrm{mmol}, 4$ eq.) was added to a stirred solution of 90 (15 mg, 0.02 mmol,) and 18-Crown-6 ether (21 mg, $0.08 \mathrm{mmol}, 4$ eq.) in $\mathrm{CH}_{3} \mathrm{CN}$ (3 mL) in a round bottom flask under $\mathrm{N}_{2}$ atmosphere. To this mixture acetic acid ( $2 \mu \mathrm{L}, 0.02$ mmol. 1 eq.) was then added and the resulting reaction mixture was stirred at $80{ }^{\circ} \mathrm{C}$ for $25 \mathrm{~min}$. The reaction mixture was then left to cool $(\sim 5 \mathrm{~min})$ and filtered to remove the left over 18 crown ether and $\mathrm{KF}$. The filtrate was washed with $\mathrm{CH}_{3} \mathrm{CN}(2 \mathrm{~mL})$ and the combined mother liquors were then concentrated under reduced pressure to give crude 94. The resulting residue was chromatographed $\left(\mathrm{MeOH} / \mathrm{CHCl}_{3} 10: 90\right)$ to give pure $94(9.5 \mathrm{mg}, 63 \%)$.

\section{4- $N$-[11-Undecanoyl-((fluoro)diisopropylsilyl)- $O$-propargylbenzyltriazol)]-2'-}

deoxy-2', 2'difluorocytidine (94). Treatment of 90 (15 mg, $0.02 \mathrm{mmol})$ using procedure reported in general procedure section gave $94(9.5 \mathrm{mg}, 63 \%)$. UV $\left(\mathrm{CH}_{3} \mathrm{OH}\right) \lambda \max 299 \mathrm{~nm}$ (ع 6500), $250 \mathrm{~nm}\left(\varepsilon\right.$ 12900), $\lambda \min 278 \mathrm{~nm}(\varepsilon 3800) ;{ }^{1} \mathrm{H}$ NMR $\left(\mathrm{CD}_{3} \mathrm{OD}\right) \delta 0.99(\mathrm{~d}, J=7.3$ $\mathrm{Hz}, 6 \mathrm{H}, i \mathrm{Pr}), 1.07$ (d, J = 7.3 Hz, 6H, $i \mathrm{Pr}), 1.24-1.47\left(\mathrm{~m}, 12 \mathrm{H}, 6 \times \mathrm{CH}_{2}\right), 1.78-1.80(\mathrm{~m}, 2 \mathrm{H}$, $\left.\mathrm{CH}_{2}\right), 1.90-1.92\left(\mathrm{~m}, 2 \mathrm{H}, \mathrm{CH}_{2}\right), 2.44\left(\mathrm{t}, J=7.4 \mathrm{~Hz}, 2 \mathrm{H}, \mathrm{CH}_{2}\right), 3.81(\mathrm{dd}, J=2.8,12.4 \mathrm{~Hz}$, 1H, H5'), 3.89-3.99 (m, 2H, H5', H4'), 4.29 (t, $\left.J=10.4 \mathrm{~Hz}, 1 \mathrm{H}, \mathrm{H} 3^{\prime}\right), 4.40$ (t, $J=7.0 \mathrm{~Hz}$, 2H), $4.60\left(\mathrm{~s}, 2 \mathrm{H}, \mathrm{CH}_{2}\right), 4.66\left(\mathrm{~s}, 2 \mathrm{H}, \mathrm{CH}_{2}\right), 6.26\left(\mathrm{t}, J=7.5,1 \mathrm{H}, \mathrm{H} 1^{\prime}\right), 7.41(\mathrm{~d}, J=7.8 \mathrm{~Hz}$, 2H, Ar), 7.49 (d, $J=7.6 \mathrm{~Hz}, \mathrm{H} 5), 7.54(\mathrm{~d}, J=8.1 \mathrm{~Hz}, 2 \mathrm{H}, \mathrm{Ar}), 7.99(\mathrm{~s}, 1 \mathrm{H}), 8.34$ (d, $J=$ 7.6 Hz, 1H, H6); ${ }^{13} \mathrm{C}$ NMR $\delta 13.22,25.92,27.80,29.90,30.11,30.20,30.33,30.41,30.50$, 38.17, 52.47, $60.30\left(\mathrm{C}^{\prime}\right), 70.27\left(\mathrm{dd}, J=22.2,23.6 \mathrm{~Hz}, \mathrm{C} 3^{\prime}\right), 82.92\left(\mathrm{~d}, J=8.6 \mathrm{~Hz}, \mathrm{C}^{\prime}\right)$, 86.42 (dd, $J=26.6,37.6 \mathrm{~Hz}, \mathrm{C} 1), 98.25(\mathrm{C} 5), 120.87$ (t, $J=259.9 \mathrm{~Hz}, \mathrm{C} 2$ '), 128.07, 135.53, 135.56, 136.34, 138.84, 145.93 (C6), 148.76, 145.93 (C6), 157.66 (C2), 164.78 (C4), $175.25(\mathrm{CO}) ;{ }^{19} \mathrm{~F}$ NMR $\delta$ - $188.86(\mathrm{~s}, 1 \mathrm{~F}),-120.09(\mathrm{~d}$ of $\mathrm{m}, J=239.2 \mathrm{~Hz}, 1 \mathrm{~F}),-119.13(\mathrm{~d}$ 
of $\mathrm{m}, J=240.2 \mathrm{~Hz}, 1 \mathrm{~F})$. HRMS (ESI+) $m / z$ calcd for $\mathrm{C}_{36} \mathrm{H}_{53} \mathrm{~F}_{3} \mathrm{~N}_{6} \mathrm{O}_{6} \mathrm{Si}[\mathrm{M}+\mathrm{H}]^{+} 751.3753$; found 751.3770 .

4- $N$-[6-Hexynoyl-((fluoro)diisopropylsilyl)- $O$-propargylbenzyltriazol)]-2'-deoxy2', 2'difluorocytidine (95). Treatment of 91 (15 $\mathrm{mg}, 0.025 \mathrm{mmol})$ using procedure reported in general procedure section gave $95(10 \mathrm{mg}, 65 \%)$. UV $\left(\mathrm{CH}_{3} \mathrm{OH}\right) \lambda \max 299 \mathrm{~nm}$ ( $\varepsilon$ 6700), $248 \mathrm{~nm}\left(\varepsilon\right.$ 13000); ${ }^{1} \mathrm{H}$ NMR $\left(\mathrm{CD}_{3} \mathrm{OD}\right) \delta 0.99(\mathrm{~d}, J=7.3 \mathrm{~Hz}, 6 \mathrm{H}, i \mathrm{Pr}), 1.06(\mathrm{~d}, J$ $=7.3 \mathrm{~Hz}, 6 \mathrm{H}, i \mathrm{Pr}), 1.18-1.20\left(\mathrm{~m}, 2 \mathrm{H}, \mathrm{CH}_{2}\right), 1.91-1.93\left(\mathrm{~m}, 2 \mathrm{H}, \mathrm{CH}_{2}\right), 2.50(\mathrm{t}, J=7.3 \mathrm{~Hz}$, 2H, $\left.\mathrm{CH}_{2}\right) .2 .78$ (t, $\left.J=7.4 \mathrm{~Hz}, 2 \mathrm{H}, \mathrm{CH}_{2}\right), 3.80-3.82$ (m, 1H, H5'), 3.93-4.05 (m, 2H, H5', H4'), 4.29-4.31 (m, 1H, H3'), 5.59 (s, 2H, $\left.\mathrm{CH}_{2}\right), 6.21$ (t, $\left.J=7.5 \mathrm{~Hz}, 1 \mathrm{H}, \mathrm{H} 1^{\prime}\right), 7.35$ (d, $J=$ $7.9 \mathrm{~Hz}, 2 \mathrm{H}$. Ar), 7.47 (d, $J=7.6 \mathrm{~Hz}, 1 \mathrm{H}, \mathrm{H} 5), 7.57$ (d, $J=8.1 \mathrm{~Hz}, 2 \mathrm{H}$. Ar), 7.81 (s, 1H), $8.33(\mathrm{~d}, J=7.6 \mathrm{~Hz}, 1 \mathrm{H}, \mathrm{H} 6) ;{ }^{13} \mathrm{C}$ NMR $\delta 13.22,13.35,16.82,17.01,25.46,25.53,37.18$ 54.70, $60.30\left(\mathrm{C5}^{\prime}\right), 70.01(\mathrm{CH}), 70.34\left(\mathrm{t}, J=23.1 \mathrm{~Hz}, \mathrm{C} 3\right.$ '), $81.72\left(\mathrm{~d}, J=8.6 \mathrm{~Hz}, \mathrm{C}^{\prime}\right), 82.92$ $\left(\mathrm{dd}, J=26.6,38.3 \mathrm{~Hz}, \mathrm{C} 1^{\prime}\right), 98.27\left(\mathrm{C}^{\prime}\right), 123.93\left(\mathrm{t}, J=259.3 \mathrm{~Hz}, \mathrm{C} 2{ }^{\prime}\right), 128.39,134.45$, 135.53, 135.56, 136.34, 138.84, 145.93 (C6), 148.76, 157.66 (C2), 164.78 (C4), 175.25 $(\mathrm{CO}) ;{ }^{19} \mathrm{~F}$ NMR $\delta-188.89(\mathrm{~s}, 1 \mathrm{~F}),-120.10(\mathrm{~d}$ of $\mathrm{m}, J=233.4 \mathrm{~Hz}, 1 \mathrm{~F}),-119.20$ (d of $\mathrm{m}, J$ $=240.9 \mathrm{~Hz}, 1 \mathrm{~F}) . \mathrm{HRMS}(\mathrm{ESI}+) \mathrm{m} / z$ calcd for $\mathrm{C}_{28} \mathrm{H}_{37} \mathrm{~F}_{3} \mathrm{~N}_{6} \mathrm{O}_{5} \mathrm{Si}[\mathrm{M}+\mathrm{Na}]^{+}$645.2445; found 645.2392 .

\section{4- $N$-[7-heptanyl-((fluoro)diisopropylsilyl)-O-propargylbenzyltriazol)]-2'-deoxy-}

2', 2'difluorocytidine (96). Treatment of $92(15 \mathrm{mg}, 0.023 \mathrm{mmol})$ using procedure reported in general procedure section gave $96(9 \mathrm{mg}, 62 \%)$. UV $\left(\mathrm{CH}_{3} \mathrm{OH}\right) \lambda \max 267 \mathrm{~nm}$ ( $\varepsilon$ 8200), $\lambda \min 228 \mathrm{~nm}(\varepsilon 7500) ;{ }^{1} \mathrm{H}$ NMR $\left(\mathrm{CD}_{3} \mathrm{OD}\right) \delta 0.99(\mathrm{~d}, J=7.3 \mathrm{~Hz}, 6 \mathrm{H}, i \mathrm{Pr}), 1.05$ $(\mathrm{d}, J=7.3 \mathrm{~Hz}, 6 \mathrm{H}, i \mathrm{Pr}), 1.31-1.41\left(\mathrm{~m}, 12 \mathrm{H}, 6 \times \mathrm{CH}_{2}\right), 1.50-1.12\left(\mathrm{~m}, 2 \mathrm{H}, \mathrm{CH}_{2}\right), 1.91(\mathrm{~m}$, 2H, $\mathrm{CH}_{2}$ ), 3.39 (m, 2H, $\mathrm{CH}_{2}$ ), 3.81 (m, 1H, H5'), 3.91-4.02 (m, 3H, H5', H4', Si-H), 4.25 
(m, 1H, H3'), $4.41\left(\mathrm{t}, J=6.9,2 \mathrm{H}, \mathrm{CH}_{2}\right), 4.60\left(\mathrm{~s}, 2 \mathrm{H}, \mathrm{CH}_{2}\right), 4.65\left(\mathrm{~s}, 2 \mathrm{H}, \mathrm{CH}_{2}\right), 5.82(\mathrm{~d}, J=$ $7.6 \mathrm{~Hz}, 1 \mathrm{H}, \mathrm{H} 5), 6.22\left(\mathrm{~m}, 1 \mathrm{H}, \mathrm{H} 1^{\prime}\right), 7.41(\mathrm{~d}, J=8.0 \mathrm{~Hz}, 2 \mathrm{H}, \mathrm{Ar}), 7.52(\mathrm{~d}, J=8.0 \mathrm{~Hz}, 2 \mathrm{H}$, Ar), $7.71(\mathrm{~d}, J=7.6 \mathrm{~Hz}, 1 \mathrm{H}, \mathrm{H6}), 8.01(\mathrm{~s}, 1 \mathrm{H}, \mathrm{CH}) .{ }^{13} \mathrm{C} \mathrm{NMR} \delta 11.26,18.76,18.96,27.01$, 27.34, 30.93, 40.97, 50.50, $60.31\left(\mathrm{C}^{\prime}{ }^{\prime}\right), 64.42,70.26\left(\mathrm{t}, J=23.1 \mathrm{~Hz}, \mathrm{C} 3{ }^{\prime}\right), 72.37,81.75(\mathrm{~d}$, $J=8.6 \mathrm{~Hz}, \mathrm{C} 4$ '), $84.92\left(\mathrm{dd}, J=26.6,38.3 \mathrm{~Hz}, \mathrm{C}^{\prime}\right), 95.97\left(\mathrm{C}^{\prime}\right), 124.04(\mathrm{t}, J=259.3 \mathrm{~Hz}$, C2'), 127.88, 133.36, 140.78, 135.56, 136.34, 138.84, 140.78 (C6), 141.02, 155.92 (C2), $164.77(\mathrm{C} 4) ;{ }^{19} \mathrm{~F}$ NMR $\delta-188.82(\mathrm{~s}, 1 \mathrm{~F}),-119.75(\mathrm{~d}$ of $\mathrm{m}, J=244.1 \mathrm{~Hz} 1 \mathrm{~F}),-119.98$ (d of $\mathrm{m}, J=239.1 \mathrm{~Hz}, 1 \mathrm{~F}$ ). HRMS (ESI + ) $\mathrm{m} / z$ calcd for $\mathrm{C}_{32} \mathrm{H}_{47} \mathrm{~F}_{3} \mathrm{~N}_{6} \mathrm{O}_{5} \mathrm{Si}[\mathrm{M}+\mathrm{Na}]^{+} 703.3227$; found 703.3234 .

\subsection{Reduction of sugar lactones to hemiacetals with LTBH}

\subsubsection{Typical procedure for reduction of the sugar lactones to hemiacetals with LTBH and selected products ${ }^{150}$}

LTBH ( $1 \mathrm{M} / \mathrm{THF} ; 0.24 \mathrm{~mL}, 0.24 \mathrm{mmol})$ was added to a solution of the appropriate sugar lactone $(0.2 \mathrm{mmol})$ in anhydrous $\mathrm{CH}_{2} \mathrm{Cl}_{2}(3 \mathrm{~mL})$ at $0{ }^{\circ} \mathrm{C}$. After $30 \mathrm{~min}$, the reaction mixture was quenched with $\mathrm{MeOH}$ and the volatiles were evaporated. The resulting residue was dissolved in $\mathrm{CH}_{2} \mathrm{Cl}_{2}(10 \mathrm{~mL})$ and washed with $\mathrm{NaHCO}_{3} / \mathrm{H}_{2} \mathrm{O}$. The organic layer was then dried $\left(\mathrm{Mg}_{2} \mathrm{SO}_{4}\right)$, evaporated and the residue was column chromatographed (7:3 / 1:1, hexane/ EtOAc, unless stated otherwise) to afford the corresponding sugar hemiacetals.

5- $\boldsymbol{O}$-Benzyl-2,3- $\boldsymbol{O}$-isopropylidene- $\boldsymbol{\alpha} / \boldsymbol{\beta}$-D-ribofuranose $(\mathbf{9 8})^{151,152}$ Reduction of $\mathbf{9 7}$ (275 mg, $1.0 \mathrm{mmol}$ ) according to the general procedure gave $\mathbf{9 8}(\alpha / \beta, 1: 4 ; 250 \mathrm{mg}, 90 \%)$. Major anomer had: ${ }^{1} \mathrm{H}$ NMR $\delta 1.31$ and $1.48\left(2 \times \mathrm{s}, 2 \times 3 \mathrm{H}, 2 \times \mathrm{CH}_{3}\right), 3.58(\mathrm{dd}, J=2.5$, $10.2 \mathrm{~Hz}, 1 \mathrm{H}, \mathrm{H} 5), 3.66$ (dd, $J=2.5,10.2 \mathrm{~Hz}, 1 \mathrm{H}, \mathrm{H} 5$ '), 4.38 (t, $J=2.2 \mathrm{~Hz}, 1 \mathrm{H}, \mathrm{H} 4), 4.52$ (d, $J=5.9 \mathrm{~Hz}, 1 \mathrm{H}, \mathrm{H} 2), 4.57(\mathrm{~d}, J=11.7 \mathrm{~Hz}, 1 \mathrm{H}, \mathrm{Bn}), 4.65(\mathrm{~d}, J=11.7 \mathrm{~Hz}, 1 \mathrm{H}, \mathrm{Bn}), 4.74$ 
$(\mathrm{d}, J=5.9 \mathrm{~Hz}, 1 \mathrm{H}, \mathrm{H} 3), 5.28(\mathrm{~d}, J=6.0 \mathrm{~Hz}, 1 \mathrm{H}, \mathrm{H} 1), 7.29-7.30(\mathrm{~m}, 5 \mathrm{H}, \mathrm{Ph}) ;{ }^{13} \mathrm{C}$ NMR $\delta$ $24.9\left(\mathrm{CH}_{3}\right), 26.5\left(\mathrm{CH}_{3}\right), 71.2(\mathrm{C} 5), 74.1(\mathrm{Bn}), 82.0(\mathrm{C} 3), 85.6(\mathrm{C} 2), 87.5(\mathrm{C} 4), 103.8(\mathrm{C} 1)$, $112.1\left(\mathrm{CMe}_{2}\right), 127.5$ (Ar), 128.5 (Ar), 136.2 (Ar); HRMS (TOF-ESI) $\mathrm{m} / z$ calcd for $\mathrm{C}_{15} \mathrm{H}_{20} \mathrm{O}_{5} \mathrm{Na}^{+}[\mathrm{M}+\mathrm{Na}]^{+}$303.1197; found 303.1188.

Minor anomer had: ${ }^{1} \mathrm{H}$ NMR $\delta 1.38$ and $1.55\left(2 \times \mathrm{s}, 2 \times 3 \mathrm{H}, 2 \times \mathrm{CH}_{3}\right), 3.54(\mathrm{dd}, J=$ 2.5, 10.2 Hz, 1H, H5), 3.61 (dd, $J=2.5,10.2 \mathrm{~Hz}, 1 \mathrm{H}, \mathrm{H} 5$ '), 4.22 (t, $J=2.2 \mathrm{~Hz}, 1 \mathrm{H}, \mathrm{H} 4$ ), $4.41(\mathrm{~d}, J=11.7 \mathrm{~Hz}, 1 \mathrm{H}, \mathrm{Bn}), 4.48(\mathrm{~d}, J=11.7 \mathrm{~Hz}, 1 \mathrm{H}, \mathrm{Bn}), 4.57$ (dd, $J=4.4,6.5 \mathrm{~Hz}, 1 \mathrm{H}$, H2), $4.71(\mathrm{dd}, J=4.4,6.5 \mathrm{~Hz}, 1 \mathrm{H}, \mathrm{H} 3), 5.47$ (dd, $J=3.8,11.9 \mathrm{~Hz}, 1 \mathrm{H}, \mathrm{H} 1), 7.29-7.30$ (m, 5H, Ph). ${ }^{13} \mathrm{C}$ NMR peaks for the ribose moiety: $\delta 72.0(\mathrm{C} 5), 73.7(\mathrm{Bn}), 79.4(\mathrm{C} 3), 79.7(\mathrm{C} 2)$, $81.8(\mathrm{C} 4), 97.8(\mathrm{C} 1)$.

5-O-Benzyl-2,3- $\boldsymbol{O}$-isopropylidene-D-ribitol (99). ${ }^{152}$ Treatment of $97(55 \mathrm{mg}, 0.20$ mmol) with 2.5 equiv. of LTBH according to the general procedure gave $\mathbf{9 8}^{152}$ (19 $\mathrm{mg}$, 34\%) followed by 99 (31 mg, 55\%). Diol 3 had: ${ }^{1} \mathrm{H}$ NMR $\delta 1.33$ and 1.38 ( 2 x s, 2 x 3H, 2 x $\left.\mathrm{CH}_{3}\right), 2.86(\mathrm{~m}, 2 \mathrm{H}, 2$ x OH), $3.55(\mathrm{dd}, J=6.7,9.6 \mathrm{~Hz}, 1 \mathrm{H}, \mathrm{H} 5), 3.74(\mathrm{dd}, J=9.6,3.0 \mathrm{~Hz}$, 1H, H5'), 3.78 (m, 1H, H1), 3.86 (dd, $J=7.8,11.6 \mathrm{~Hz}, 1 \mathrm{H}, \mathrm{H1}$ '), 3.96 (m, 1H, H4), 4.10 (dd, $J=5.8,9.6 \mathrm{~Hz}, 1 \mathrm{H}, \mathrm{H} 3), 4.35(\mathrm{dt}, J=5.2,8.1 \mathrm{~Hz}, 1 \mathrm{H}, \mathrm{H} 2), 4.59(\mathrm{~s}, 2 \mathrm{H}, \mathrm{Bn}), 7.34(\mathrm{~m}$, $5 \mathrm{H}, \mathrm{Ph})$.

\section{4,6-O-Benzylidene-2,3-bits- $O$-(tert-butyldimethylsilyl)- $\alpha$ / $\beta$-D-glucopyranose}

(158) Reduction of 157 (50 mg, $0.1 \mathrm{mmol}$; prepared by standard silylation 4,6-Obenzylidene-D-glucopyranose ${ }^{153}$ with TBDMS/imidazole/DMF) according to the general procedure gave $158(\alpha / \beta, 1: 1,39 \mathrm{mg}, 80 \%):{ }^{1} \mathrm{H}$ NMR $\delta$ 0.010-0.17 (6 x s, $\left.12 \mathrm{H}, \mathrm{MeSi}\right)$, 0.75-0.98 (2 x s, 18H, $t$-BuSi), 3.92-4.00 (m, 1.5H), 4.13-4.20 (m, 2H), $4.25(\mathrm{~m}, 1 \mathrm{H}), 4.35$ $(\mathrm{m}, 0.5 \mathrm{H}), 4.44(\mathrm{~m}, 1 \mathrm{H}), 5.07(\mathrm{~m}, 0.5 \mathrm{H}, \mathrm{H1}), 5.65(\mathrm{~m}, 0.5 \mathrm{H}, \mathrm{H} 1), 6.12(\mathrm{~s}, 0.5 \mathrm{H}, \mathrm{CHPh})$, 
6.16 (s, 0.5H, CHPh), 7.35-7.48 (m, 5H, Ph); ${ }^{13} \mathrm{C}$ NMR $\delta$-5.49, -5.46, -5.44, -5.17, -4.84, -4.77, -4.74, -4.71 (MeSi), $18.1\left(\mathrm{CMe}_{3}\right), 18.2\left(\mathrm{CMe}_{3}\right), 18.3\left(\mathrm{CMe}_{3}\right), 25.7(\mathrm{Me}), 25.8(\mathrm{Me})$, 26.0 (Me), 26.1 (Me), 66.3 (C6), 66.4 (C6), 72.6 (C5), 74.7 (C5), 75.2 (C4), 75.3 (C4), 76.2 (C3), 79.8 (C3), 80.0 (C2), 80.7 (C2), 96.0 (CH-Ph), 97.5 (CH-Ph), 100.1 (C1), 103.8 (C1), 126.1 (Ar), $126.4(\mathrm{Ar}), 128.5(\mathrm{Ar}), 128.6(\mathrm{Ar}), 129.3(\mathrm{Ar}), 129.9(\mathrm{Ar}), 138.2(\mathrm{Ar})$, 138.5 (Ar); HRMS (TOF-ESI) $\mathrm{m} / z$ calcd for $\mathrm{C}_{25} \mathrm{H}_{44} \mathrm{O}_{6} \mathrm{Si}_{2} \mathrm{Na}^{+}[\mathrm{M}+\mathrm{Na}]^{+}$519.2569; found 519.2587

\subsection{2. ${ }^{1} \mathrm{H}$ NMR reaction profile for reduction of sugar lactone 97}

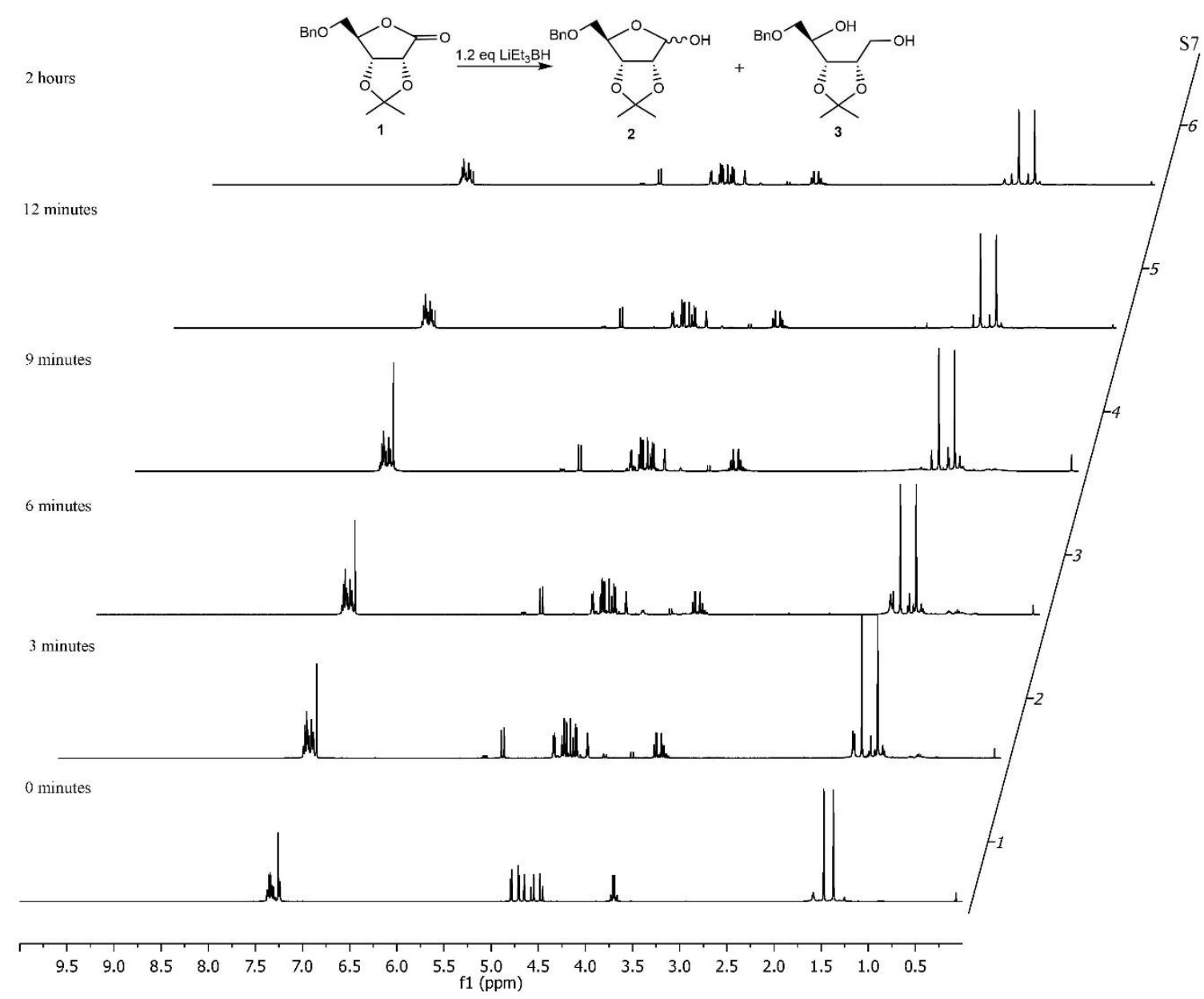

Figure 41. ${ }^{1} \mathrm{H}$ NMR spectra of reaction profile with 1.2 equiv. of LTBH 


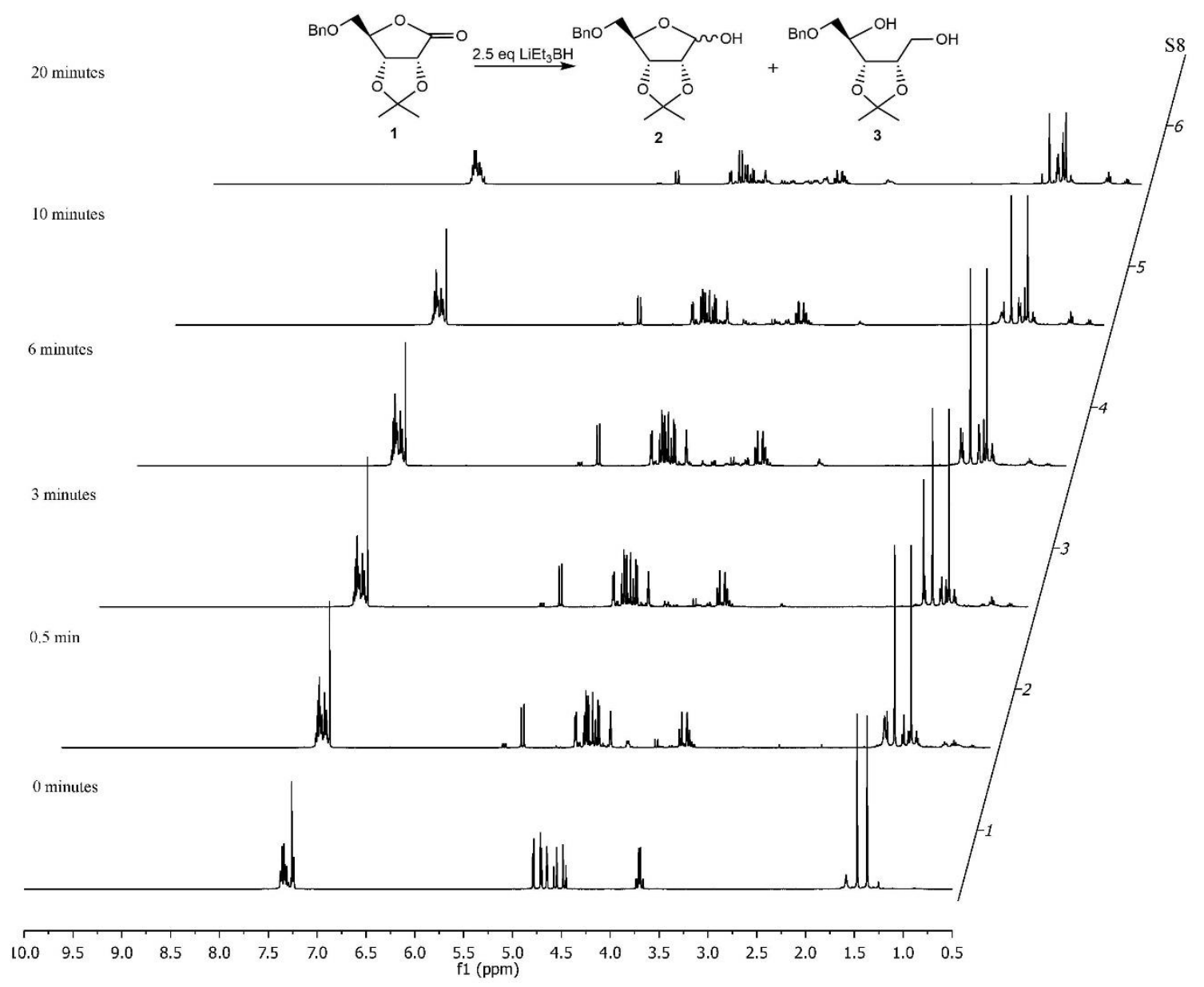

Figure 42. ${ }^{1} \mathrm{H}$ NMR spectra of reaction profile with 2.5 equiv. of LTBH

\subsection{Biological evaluation and studies for 4- $N$-alkanoyl and alkyl gemcitabine analogues}

\section{Cytostatic evaluation in L1210 mouse leukemic cells}

The L12010 cells were cultured in DMEM medium supplemented with $10 \%$ fetal bovine serum and antibiotics (Penicillin and Streptomycin) in a 5\% $\mathrm{CO}_{2}$ incubator maintained at $37^{\circ} \mathrm{C}$. Log phase cells were harvested and plated at $1.0 \times 10^{4}$ cells/well in 96-well microtiter plates. After cell attachment was assured, cells in microtiter plates were treated with increasing concentrations of gemcitabine analogs $(0-200 \mu \mathrm{g} / \mathrm{ml})$ and incubated in the $\mathrm{CO}_{2}$ incubator at $37{ }^{\circ} \mathrm{C}$ for $72 \mathrm{~h}$ to induce cell death. MTT assay was performed 
using the Cell Proliferation kit I (MTT) from Roche Biochemicals (Indianapolis, IN) and the plates were read in a Bio-Rad Benchmark multiwell plate reader at $570 \mathrm{~nm}$ wavelength with a reference wavelength of $655 \mathrm{~nm}$. The percentage of surviving cells (\% of control) was calculated and plotted against drug concentrations for estimating the IC (inhibitory concentration) values.

\section{Cytostatic evaluation in HEK 293 cells}

HEK 293 cells were cultured in DMEM medium supplemented with 10\% fetal bovine serum and antibiotics (Penicillin and Streptomycin) in $5 \% \mathrm{CO}_{2}$ incubator maintained at 37 ${ }^{\circ} \mathrm{C}$. Log phase cells were harvested and plated at $1.0 \times 10^{4}$ to $1.0 \times 10^{5}$ cells/well in $24-$ well microtiter plates. After $24 \mathrm{~h}$ incubation, cells were treated with increasing concentrations of gemcitabine analogs $(0-200 \mu \mathrm{g} / \mathrm{ml})$ and incubated in the $\mathrm{CO}_{2}$ incubator at $37^{\circ} \mathrm{C}$ for 24 to $72 \mathrm{~h}$. Then, MTT reagent (Roche Diagnostics Corporation, Indianapolis, IN) was added at a final concentration of $50 \mu \mathrm{g} / \mathrm{ml}$, and further incubated at $37^{\circ} \mathrm{C}$ and $5 \% \mathrm{CO}_{2}$. Next, the formazan crystals were dissolved in a detergent reagent, and each condition was then quantified via spectrophotometry (Bio-Rad Benchmark multiwell plate reader) at an optical density of $570 \mathrm{~nm}\left(\mathrm{OD}_{570}\right)$.

\section{Cell proliferation: HPLC studies with HEK 293 cells}

For intracellular localization of 86, HEK 293 cells were washed twice with PBS and then lysed with cell lysis buffer $(50 \mathrm{mM}$ Tris- $\mathrm{HCl}, 150 \mathrm{mM} \mathrm{NaCl}, 0.1 \%$ SDS, $0.5 \%$ sodium deoxycholate, $1 \%$ NP-40) in the presence of protease and phosphatase inhibitors. Lysates were collected with cell scrapers and cleared by centrifugation. Prior to HLPC analysis, cell lysates were re-suspended in $\mathrm{H}_{2} \mathrm{O}$, extracted with EtOAc and then subject to RP-HPLC analysis. 


\section{HEK 293 Cell Fluorescence Procedure}

\section{Cell incubation}

HEK 293 cells were seeded in plates containing glass coverslips and incubated overnight. After incubation, fresh media solutions containing $86(100 \mu \mathrm{M})$ was added and then incubated for various durations $(6,12$ and $24 \mathrm{~h})$. Cells were fixed in paraformaldehyde (3.7\%) for $15 \mathrm{~min}$ at room temperature, quenched, and washed with PBS as essentially described by Neef et al. ${ }^{131}$

\section{CuAAC-mediated staining in fixed cells}

HEK 293 Cells on coverslips were incubated upside-down with $50 \mu \mathrm{L}$ of freshly prepared staining mix $\left(10 \mu \mathrm{M}\right.$ Fluor alkyne, $1 \mathrm{mM} \mathrm{CuSO}_{4}$, and $10 \mathrm{mM}$ sodium ascorbate in PBS) for $1 \mathrm{~h}$ at room temperature in the dark. Cells were then to be washed with $0.1 \%$ Triton X-100 (in order to efficiently dissolve cellular membranes) in PBS, and PBS. Cells were then stained with DAPI for 15 min at room temperature in the dark. After incubation, cells were washing with PBS and coverslips were mounted and viewed on an Olympus FV1200 Laser confocal microscope.

\section{Statistical analysis}

All experiments were independently performed in triplicate. The standard error of the mean (SEM) of triplicates was utilized and significance was analyzed by one-way ANOVA. All statistical data were from averages of the three independent experiments. Results with $* \mathrm{P}<0.01$ was considered statistically significant. 


\subsection{Radiosynthesis of ${ }^{18}$ F Fluoro-silane probes}

\section{Materials}

No-carrier-added $\left[{ }^{18} \mathrm{~F}\right]$ fluoride was produced by the ${ }^{18} \mathrm{O}(\mathrm{p}, \mathrm{n}){ }^{18} \mathrm{~F}$ reaction of $\left[{ }^{18} \mathrm{O}\right] \mathrm{H}_{2} \mathrm{O}$ (84\% isotopic purity, Zevacor Pharma, Noblesville, IN, USA) in an RDS-112 cyclotron (Siemens; Knoxville, TN, USA) at $11 \mathrm{MeV}$ using a $1 \mathrm{~mL}$ tantalum target with havar foil. Anhydrous grade acetonitrile $\left(\mathrm{CH}_{3} \mathrm{CN}\right)$, dimethylsulfoxide (DMSO), potassium carbonate $\left(\mathrm{K}_{2} \mathrm{CO}_{3}\right), 200$-proof ethanol $(\mathrm{EtOH})$, and glacial acetic acid $(\mathrm{AcOH})$ were purchased from Sigma-Aldrich (Milwaukee, WI, USA). HPLC grade acetonitrile was purchase from Fisher Scientific (Pittsburg, PA, USA). 4,7,13,16,21,24-Hexaoxa-1,10diazabicyclo[8.8.8]hexacosane (Kryptofix $\mathrm{K}_{222}$ ) and pre-conditioned quarternary methylammonium (QMA) cartridges were purchased from ABX Advanced Biochemical Compounds (Radeberg, Germany). The t-C18 plus short cartridge (WAT036810) was purchased from Waters (Milford, MA, USA).

For microfluidic radiochemistry chip fabrication, sulfuric acid (96\%, cleanroom MB), hydrogen peroxide (30\%, cleanroom LP), acetone (99.5\%, cleanroom MB), and methanol (99.9\%, cleanroom LP) were purchased from XMG Electronic Chemicals Inc. (Houston, TX, USA). Tridecafluoro-1,1,2,2-tetrahydrooctyl trichlorosilane (silane) was purchased from Gelest, Inc. (Morrisville, PA, USA), and Teflon AF 2400 1\% solution was purchased from DuPont Fluoroproducts (Wilmington, DE, USA). Tape (TimeMed Label Tape) was obtained from Fisher Scientific.

\section{Chromatography and analytical methods}

Purification of $\left[{ }^{18} \mathrm{~F}\right] \mathbf{1 0 8}$ was performed by semi-preparative HPLC using a WellChrom K-501 HPLC pump (Knauer; Berlin, Germany), reversed-phase Gemini-NX (5 $\mu \mathrm{m}, 10 \mathrm{x}$ 
$250 \mathrm{~mm}$, Phenomenex) column, ultraviolet (UV) detector (254 nm, WellChrom Spectrophotometer K-2501, Knauer) and gamma-radiation detector and counter (B-FC3300 and B-FC-1000; Bioscan Inc.; Washington, DC, USA). Injection was performed using the ELIXYS HPLC injection valve connected to a $5 \mathrm{~mL}$ loop. The flow rate was 5 $\mathrm{mL} / \mathrm{min}$ and a gradient elution of $\mathrm{CH}_{3} \mathrm{CN}$ in $\mathrm{H}_{2} \mathrm{O}$ was used $\left(5 \% \mathrm{v} / \mathrm{v} \mathrm{CH}_{3} \mathrm{CN}\right.$ for $0-5 \mathrm{~min}$, ramp to $20 \% \mathrm{MeCN}$ at $10 \mathrm{~min}$, ramp to $30 \% \mathrm{CH}_{3} \mathrm{CN}$ at $20 \mathrm{~min}$ ). The collected $\mathrm{HPLC}$ fraction was diluted with $\mathrm{H}_{2} \mathrm{O}(30 \mathrm{~mL})$ and trapped on a $\mathrm{tC} 18$ plus cartridge previously conditioned with $5 \mathrm{~mL}$ of $\mathrm{EtOH}$ and $10 \mathrm{~mL}$ of $\mathrm{H}_{2} \mathrm{O}$. The cartridge was then rinsed with additional $\mathrm{H}_{2} \mathrm{O}(5 \mathrm{~mL})$ and eluted with $\mathrm{EtOH}(1 \mathrm{~mL})$. After complete evaporation of EtOH at $80^{\circ} \mathrm{C}$, the purified product was dissolved in $2-3 \mathrm{~mL}$ PBS. $\left[{ }^{18} \mathrm{~F}\right] \mathbf{9 4}$ was synthesized but not purified.

Analytical HPLC was used to confirm the identity and radiochemical purity of the synthesized compound. Analytical HPLC was performed on a Knauer Smartline HPLC system with a C18 reverse-phase (Luna column ( $5 \mu \mathrm{m}, 4.6$ x $250 \mathrm{~mm}$, Phenomenex) with in-line Knauer UV (254 nm) and gamma-radiation coincidence detector and counter (BFC-4100 and B-FC-1000). Injections were performed with a manual injection valve (Rheodyne $7725 i$ ) with a $200 \mu \mathrm{L}$ loop. For analysis of $\left[{ }^{18} \mathrm{~F}\right] \mathbf{9 6}$, the mobile phase with $60 \%$ v/v $\mathrm{CH}_{3} \mathrm{CN}$ in $\mathrm{H}_{2} \mathrm{O}$ and flow rate was $1 \mathrm{~mL} / \mathrm{min}$. Retention times of 92 and 96 were 8.0 and $6.2 \mathrm{~min}$, respectively. For analysis of $\left[{ }^{18} \mathrm{~F}\right] \mathbf{9 4}$, the mobile phase was $80 \% \mathrm{v} / \mathrm{v} \mathrm{CH}_{3} \mathrm{CN}$ in $\mathrm{H}_{2} \mathrm{O}$ and flow rate was $1.5 \mathrm{~mL} / \mathrm{min}$. Retention times of $\mathbf{9 0}$ and $\mathbf{9 4}$ were 6.1 and $4.3 \mathrm{~min}$, respectively.

Radio-thin-layer-chromatography (radio-TLC) was performed on precut silica plates (Baker-flex ${ }^{\circledR}$, J.T.Baker; Phillipsburg, NJ, USA). After spotting a tiny sample volume ( 1- 
$5 \mu \mathrm{L}$ ) using a glass capillary, the plate was developed in the mobile phase. Chromatograms were obtained using a radio-TLC scanner (miniGita Star, Raytest USA, Inc.). The mobile phase was $95 \%$ v/v $\mathrm{CH}_{3} \mathrm{CN}$ in $\mathrm{H}_{2} \mathrm{O}$. The $\mathrm{R}_{\mathrm{f}}$ values for unreacted $\left[{ }^{18} \mathrm{~F}\right]$ fluoride, $\left[{ }^{18} \mathrm{~F}\right] \mathbf{9 4}$ and $\left[{ }^{18} \mathrm{~F}\right] 96$ were $0.0,0.64$, and 0.72 , respectively.

Radiochemical purity (RCP) was determined by using both the radio-TLC and radioHPLC radiation-detector chromatograms. The radio-TLC chromatogram enabled estimation of the fraction of $\left[{ }^{18} \mathrm{~F}\right]$ fluoride that had been converted to product (plus any byproducts). The radio-HPLC chromatogram (ignoring the $\left[{ }^{18} \mathrm{~F}\right]$ fluoride peak) enabled estimation of the fraction of the desired product among ${ }^{18} \mathrm{~F}$-labeled species. The RCP was computed as the product of these two fractions. Crude radiochemical yield (crude RCY) was computed as the RCP multiplied by the fraction of the starting radioactivity collected at the end of the reaction (corrected for radioactive decay). Isolated RCY was determined by dividing the radioactivity of the purified, formulated product by the starting radioactivity (corrected for radioactive decay).

\section{Macroscale radiosyntheses of 4- $N$-alkanoyl $\left[{ }^{18} \mathrm{~F}\right] 94$ and $4-N$-alkyl $\left[{ }^{18} \mathrm{~F}\right] 96$}

The one-pot syntheses of $4-N$-alkanoyl $\left[{ }^{18} \mathrm{~F}\right] \mathbf{9 4}$ and $4-N$-alkyl $\left[{ }^{18} \mathrm{~F}\right] \mathbf{9 6}$ were adapted from literature ${ }^{90,99}$ and performed on the ELIXYS FLEX/CHEM radiosynthesizer (Sofie Biosciences, Inc., Culver City, CA, USA). Briefly, $\left[{ }^{18} \mathrm{~F}\right]$ fluoride in $\left[{ }^{18} \mathrm{O}\right] \mathrm{H}_{2} \mathrm{O}(1.9-37 \mathrm{GBq}$ [50-1000 $\mathrm{mCi}]$; average $15 \mathrm{GBq}$ [400 $\mathrm{mCi}]$ ) was trapped on a pre-conditioned QMA cartridge and eluted with $0.8 \mathrm{~mL}$ of a $3: 5 \mathrm{H}_{2} \mathrm{O}: \mathrm{CH}_{3} \mathrm{CN}$ (v/v) solution containing $7 \mathrm{mg}$ $\mathrm{K}_{2} \mathrm{CO}_{3}$ and $23 \mathrm{mg} \mathrm{K} \mathrm{K}_{22}$ into the reaction vessel. This solution was then dried at $110^{\circ} \mathrm{C}$ under nitrogen stream (7psi) and vacuum. To remove residual water, additional $\mathrm{CH}_{3} \mathrm{CN}(1.2 \mathrm{~mL})$ was added and the mixed solution again evaporated. This step was repeated a second time 
to ensure water was fully removed. $2.5 \mathrm{mg}$ of precursor (90 or 92) in DMSO with $1 \% \mathrm{v} / \mathrm{v}$ $\mathrm{AcOH}$ was then added to the dried $\left[{ }^{18} \mathrm{~F}\right] \mathrm{KF} / \mathrm{K}_{222}$ residue and reacted at $100^{\circ} \mathrm{C}$ for $25 \mathrm{~min}$. After cooling, $2 \mathrm{~mL}$ of HPLC mobile phase was added, and the crude mixture was transferred to a $5 \mathrm{~mL}$ injection loop for HPLC purification.

The synthesis of $\left[{ }^{18} \mathrm{~F}\right] 94$ was performed only once. The crude radiochemical yield was $0.5 \%(\mathrm{n}=1)$ and further purification or synthesis optimization was not pursued. For $\left[{ }^{18} \mathrm{~F}\right] 96$, the radiochemical yield was $6.6 \%(\mathrm{n}=5)$ and the radiochemical purity was $>99 \%$.

The synthesis time was $84 \mathrm{~min}$, including purification and formulation.

The detailed ELIXYS synthesis program is describe in table 9, and the reagent setup is described in table 10 .

Table 9. Details of ELIXYS radiosynthesis program.

\begin{tabular}{|c|c|c|c|c|c|c|c|}
\hline Index & Operation & Source & Destination & $\begin{array}{l}\text { Duration } \\
\text { (s) }\end{array}$ & $\begin{array}{c}\text { Temperature } \\
\left({ }^{\circ} \mathrm{C}\right)\end{array}$ & $\begin{array}{c}\text { Pressure } \\
(\mathrm{psi})\end{array}$ & $\begin{array}{c}\text { Other } \\
\text { Parameters }\end{array}$ \\
\hline 1 & $\begin{array}{l}\text { Trap } \\
\text { radionuclide }\end{array}$ & $\begin{array}{l}\text { Source } \\
\text { vial }\end{array}$ & Reactor 3 & 90 & -- & 7 & \\
\hline 2 & $\begin{array}{l}\text { Elute } \\
\text { radionuclide }\end{array}$ & $\begin{array}{l}\text { Reagent } \\
1\end{array}$ & Reactor 3 & 90 & -- & 7 & \\
\hline 3 & Evaporate & -- & Reactor 3 & 210 & 110 & 7 & $\begin{array}{l}\text { Stirring } \\
\text { (500rpm); } \\
\text { Cooling: } \\
35^{\circ} \mathrm{C}\end{array}$ \\
\hline 4 & $\begin{array}{l}\text { Elute } \\
\text { radionuclide }\end{array}$ & $\begin{array}{l}\text { Reagent } \\
2\end{array}$ & Reactor 3 & 60 & -- & 7 & \\
\hline 5 & Evaporate & -- & Reactor 3 & 105 & 110 & 7 & $\begin{array}{l}\text { Stirring } \\
\text { (500rpm); } \\
\text { Cooling: } \\
35^{\circ} \mathrm{C}\end{array}$ \\
\hline 6 & $\begin{array}{l}\text { Add } \\
\text { Reagent }\end{array}$ & $\begin{array}{l}\text { Reagent } \\
3\end{array}$ & Reactor 3 & 15 & -- & 3 & $\begin{array}{l}\text { Add needle: } \\
1 ; \\
\text { No stirring }\end{array}$ \\
\hline 7 & Evaporate & -- & Reactor 3 & 105 & 110 & 8 & $\begin{array}{l}\text { Stirring } \\
\text { (500rpm); } \\
\text { Cooling: } \\
35^{\circ} \mathrm{C}\end{array}$ \\
\hline
\end{tabular}




\begin{tabular}{|c|c|c|c|c|c|c|c|}
\hline 8 & $\begin{array}{l}\text { Add } \\
\text { Reagent }\end{array}$ & $\begin{array}{l}\text { Reagent } \\
4\end{array}$ & Reactor 3 & 15 & - & 3 & $\begin{array}{l}\text { Add needle: } \\
1 ; \text { No } \\
\text { stirring }\end{array}$ \\
\hline 9 & React & -- & Reactor 3 & 1500 & 100 & -- & $\begin{array}{l}\text { Seal } \\
\text { position: } 1 \text {; } \\
\text { Stirring } \\
\text { (500rpm); } \\
\text { Cooling: } \\
35^{\circ} \mathrm{C}\end{array}$ \\
\hline 10 & $\begin{array}{l}\text { Add } \\
\text { Reagent }\end{array}$ & $\begin{array}{l}\text { Reagent } \\
5\end{array}$ & Reactor 3 & 15 & -- & 3 & $\begin{array}{l}\text { Add needle: } \\
1 ; \\
\text { Stirring } \\
\text { (20s at } \\
500 \text { rpm } \\
\text { after } 15 \mathrm{~s} \\
\text { delay) }\end{array}$ \\
\hline 11 & Transfer & $\begin{array}{l}\text { Reactor } \\
3\end{array}$ & HPLC & 0 & -- & 0 & $\begin{array}{l}\text { Flow path: } \\
\text { out; } \\
\text { Loop } \\
\text { loading } \\
\text { mode: } \\
\text { manual; } \\
\text { No stirring }\end{array}$ \\
\hline
\end{tabular}

Table 10. Details of reagent positions in ELIXYS cassette.

\begin{tabular}{|c|c|c|c|c|c|}
\hline \multirow[t]{2}{*}{ Cassette \# } & \multicolumn{5}{|c|}{ Reagent Position } \\
\hline & 1 & 2 & 3 & 4 & 5 \\
\hline 1 & $\begin{array}{c}\text { Eluent } \\
\left(7 \mathrm{mg} \mathrm{K}_{2} \mathrm{CO}_{3}\right. \\
+23 \mathrm{mg} \\
\mathrm{K} 222 \text { in } 300 \\
\mu \mathrm{L} \mathrm{H}_{2} \mathrm{O}+ \\
500 \mu \mathrm{L} \\
\left.\mathrm{CH}_{3} \mathrm{CN}\right)\end{array}$ & $\begin{array}{c}\mathrm{CH}_{3} \mathrm{CN} \\
(1.2 \mathrm{~mL})\end{array}$ & $\begin{array}{c}\mathrm{CH}_{3} \mathrm{CN} \\
(1.2 \mathrm{~mL})\end{array}$ & $\begin{array}{c}\text { Precursor } \\
(2-3 \mathrm{mg} \text { in } \\
400 \mu \mathrm{L} \\
\text { DMSO }+1 \% \\
\text { v/v AcOH) }\end{array}$ & $\begin{array}{c}\mathrm{CH}_{3} \mathrm{CN} / \mathrm{H}_{2} \mathrm{O} \\
(2 \mathrm{~mL}, 5 / 95 \\
\mathrm{v} / \mathrm{v})\end{array}$ \\
\hline
\end{tabular}

\section{Microscale radiosyntheses of 4-N-alkanoyl $\left[{ }^{18} \mathrm{~F}\right] 94$ and $4-N$-alkyl $\left[{ }^{18} \mathrm{~F}\right] 96$}

\section{Microscale radiochemistry chip fabrication}

The microscale synthesis was performed in microdroplets on a simple microfluidic chip. ${ }^{138,139}$ Glass microscope slides were cut into square pieces ( $\left.25 \times 25 \times 1 \mathrm{~mm}\right)$, and cleaned by sonication in acetone ( $5 \mathrm{~min})$, sonication in $\mathrm{MeOH}(5 \mathrm{~min})$, rinsing with DI 
water, and were then dried with nitrogen. Additional cleaning was then performed by submerging the glass pieces into Pirahna cleaning solution (3:1 v/v mixture of sulfuric acid (96\%) and hydrogen peroxide (30\%)) for 15-30 min, then rinsing with DI water and drying with nitrogen. Cleaned substrates were silanized by placing then in a sealed chamber with a few drops of silane under reduced pressure overnight, followed by heating at $110^{\circ} \mathrm{C}$ for 10 min on a hot plate. Teflon AF solution was spin-coated (Headway PWM 32, Headway Research Inc., Garland, TX, USA ) on one side of each chip using the following 3-step program: $500 \mathrm{RPM}$ for $5 \mathrm{~s}$ (ramp rate $100 \mathrm{RPM} / \mathrm{s}$ ), $1000 \mathrm{RPM}$ for $30 \mathrm{~s}$ (ramp rate 500 $\mathrm{RPM} / \mathrm{s}$ ) and $0 \mathrm{RPM}$ (ramp rate $1000 \mathrm{RPM} / \mathrm{s}$ ). After coating, the glass chips were heated on a hotplate at $160^{\circ} \mathrm{C}$ for $10 \mathrm{~min}$, then at $245^{\circ} \mathrm{C}$ for $10 \mathrm{~min}$. Finally, the Teflon-coated chips were baked in a Carbolite oven (HTCR6 28 with 3216P1 programmer option, Carbolite Gero Ltd., UK) at $340^{\circ} \mathrm{C}$ for $3.5 \mathrm{~h}$.

\section{Temperature control}

A custom temperature control system was assembled to heat and cool the glass chip. Heating was accomplished on top of a small rectangular $180 \mathrm{~W}$ ceramic heater with a builtin thermocouple (CER-1-01-00098 Ultramic heater, Watlow Electric Manufacturing Co., St. Louis, MO, USA). The heater temperature was controlled with a LabView program (National Instruments, Austin, TX, USA) using the thermocouple signal received through a data acquisition module (USB-201, Measurement Computing, Norton, MA, USA) via an on-off algorithm. The heater was affixed to a thermoelectric (Peltier) device for heat insulation and accelerated cooling of the when necessary. The Peltier device was fixed on an aluminum heatsink and fan. A small amount of thermal paste was used for adhesion and better thermal contact between chip and heater, heater and Peltier, and Peltier and heatsink. 


\section{On-chip synthesis}

The microdroplet synthesis was performed using two Teflon-coated glass chips as shown in Figure 43. The first was placed (Teflon-coated side up) on the heater. $\left[{ }^{18} \mathrm{~F}\right]$ fluoride in $\left[{ }^{18} \mathrm{O}\right] \mathrm{H}_{2} \mathrm{O}(10 \mu \mathrm{L} ; \sim 150 \mathrm{MBq}[4 \mathrm{mCi}])$ was mixed with $12 \mu \mathrm{L}$ of a $70: 30$ v/v $\mathrm{CH}_{3} \mathrm{CN} / \mathrm{H}_{2} \mathrm{O}$ solution containing $\mathrm{K}_{222}(0.23 \mu \mathrm{g})$ and $\mathrm{K}_{2} \mathrm{CO}_{3}(0.07 \mu \mathrm{g})$ and deposited in the center of the chip. Additional $\mathrm{CH}_{3} \mathrm{CN}(10 \mu \mathrm{L})$ was added to aid in azeotropic drying, and the chip was heated at $105^{\circ} \mathrm{C}$ until the droplet on chip shrank to a small volume $(\sim 1 \mu \mathrm{L})$. Next, $0.2 \mu \mathrm{g}$ precursor (90 or 92 ) in $30 \mu \mathrm{L}$ of DMSO with $1 \% \mathrm{v} / \mathrm{v}$ AcOH was added to the dried $\left[{ }^{18} \mathrm{~F}\right] \mathrm{KF} / \mathrm{K}_{222}$ residue, and the reaction droplet was covered with the second glass chip (Teflon-coated side down). Tape affixed to the edges of the top chip resulted in a gap of $\sim 150 \mu \mathrm{m}$ between the substrates. The chip was heated at $100^{\circ} \mathrm{C}$ for $20 \mathrm{~min}$. Crude product was extracted from chip by adding $20 \mu \mathrm{L}$ of $1: 1 \mathrm{v} / \mathrm{v}$ MeOH: $\mathrm{H}_{2} \mathrm{O}$ solution and then collecting the diluted mixture with a pipette. This process was repeated $2 \mathrm{x}$ for each substrate $(\sim 80 \mu \mathrm{L}$ total volume $)$.

Without purification, the microscale synthesis took $45 \mathrm{~min}$. Decay-corrected crude radiochemical yield for $4-N$-alkanoyl $\left[{ }^{18} \mathrm{~F}\right] 94$ was $10 \%(\mathrm{n}=1)$ and for $4-N$-alkyl $\left[{ }^{18} \mathrm{~F}\right] 96$ was $24.4 \%(\mathrm{n}=5)$. The crude yield for $4-\mathrm{N}$-alkanoyl $\left[{ }^{18} \mathrm{~F}\right] 94$ was $10 \%(\mathrm{n}=1)$ and for $4-N$ alkyl $\left[{ }^{18} \mathrm{~F}\right] 96$ was $27.2 \%(\mathrm{n}=5)$. Purification and formulation added additional time to the synthesis.

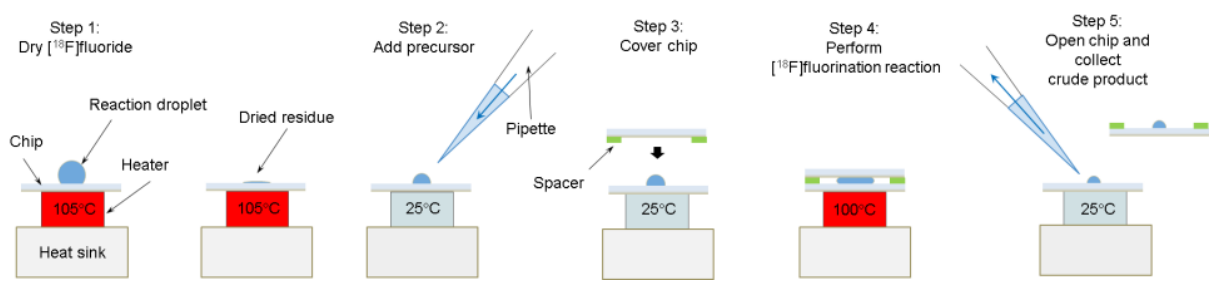

Figure 43. Schematic of the microdroplet radiosynthesis process. 


\subsection{Biological and PET evaluation of $\left[{ }^{18} \mathrm{~F}\right]-4-N$-alkyl gemcitabine radioligand 96 Stability in formulation}

\section{Methods}

After purification, the collected HPLC fraction $(3-4 \mathrm{~mL})$ of $\left[{ }^{18} \mathrm{~F}\right] 96$ was collected in a V-vial. The mobile phase was evaporated to dryness at $75^{\circ} \mathrm{C}$ with nitrogen stream. The dried residue was then dissolved in $0.3 \mathrm{~mL}$ EtOH. $2.7 \mathrm{~mL}$ saline was added to the vial, and the mixture was passed through a sterilization filter. Samples of the formulated tracer were analyzed via radio-HPLC (analytical conditions previously described) at various timepoints.

\section{In vivo imaging}

\section{Methods}

PET/CT was performed on the Genisys 8 PET/CT (Sofie Biosciences, USA). The Genisys $8 \mathrm{PET} / \mathrm{CT}$ is an integrated scanner with a PET subsection that consists of 8 detectors with BGO scintillator array arranged in a box geometry and a back section consisting of a rotating CT gantry.

For static PET scans, a WT C57BL/6 mouse was injected with approximately $75 \mu \mathrm{Ci}$ $\left[{ }^{18} \mathrm{~F}\right] 96$ via tail vein. After $60 \mathrm{~min}$ of conscious uptake, mice were anesthetized with $1.5 \%$ isoflurane and placed in a dedicated imaging chamber. microPET images were acquired for $600 \mathrm{sec}$ with an energy window of $150-650 \mathrm{keV}$, reconstructed using maximumlikelihood expectation maximization as recommended by the vendor. All images were corrected for CT-based photon attenuation, detector normalization and radioisotope decay (scatter correction was not applied) and converted to units of percent injected dose per $\operatorname{gram}(\% \mathrm{ID} / \mathrm{g})$. 
For dynamic PET scans, a WT C57BL/6 mouse was anesthetized with 2\% isoflurane, placed in a dedicated imaging chamber with heating, and catheterized. Dynamic microPET imaging was started concurrently at the beginning of a $10 \mathrm{sec}$ infusion via the catheter with approximately $75 \mu \mathrm{Ci}$ of $\left[{ }^{18} \mathrm{~F}\right] \mathbf{9 6}$. Data was acquired in listmode for $3600 \mathrm{sec}$ with an energy window of 150-650 keV and histogrammed into a frame sequence of 4 x $15 \mathrm{sec}, 8$ x $30 \mathrm{sec}, 5$ x $60 \mathrm{sec}, 4$ x $300 \mathrm{sec}, 3$ x $600 \mathrm{sec}$. Images were reconstructed using maximumlikelihood expectation maximization as recommended by the vendor. All images were corrected for photon attenuation, detector normalization and radioisotope decay (scatter correction was not applied) and converted to units of percent injected dose per gram $(\% \mathrm{ID} / \mathrm{g})$.

All PET acquisitions were immediately followed by CT acquisition. The CT section consists of a gantry and flywheel that uses a $50 \mathrm{kVp}, 200 \mathrm{uA}$ x-ray source and flat-panel detector. The CT acquires images in a continuous-rotation mode and with standard CT acquisition time of $50 \mathrm{~s}$. Standard scans are acquired with 720 projections at $55 \mathrm{~ms}$ per projection, and reconstructed using a Feldkamp algorithm.

\section{Metabolite analysis}

\section{Methods}

In one experiment, mouse blood was incubated with $0.5 \mathrm{mCi}$ of $\left[{ }^{18} \mathrm{~F}\right] \mathbf{9 6}$ for $30 \mathrm{~min}$ at $37^{\circ} \mathrm{C}$. A sample of this mixture was taken and centrifuged for $5 \mathrm{~min}$. The supernatant (plasma fraction) was collected. The pellet (cell fraction) was washed twice with PBS and the collected liquid mixed with the previous plasma fraction. The radioactivity in each fraction was measured. 
In a second experiment, a mouse was injected via tail vein with $1 \mathrm{mCi}$ of $\left[{ }^{18} \mathrm{~F}\right] 96$ and $800 \mu \mathrm{L}$ was drawn from the mouse 30 min after injection, and was separated and counted as above. 


\section{CONCLUSION}

In this dissertation I reported the synthesis of gemcitabine analogues with 4- $\mathrm{N}$-alkanoyl and 4- $\mathrm{N}$-alkyl modifications bearing i) $\beta$-keto sulfonate moiety or ii) silicon-fluoride acceptor building blocks with both chemotherapeutic properties and ability for the ${ }^{18} \mathrm{~F}$ incorporation with possible application as gemcitabine PET radiotracers.

The 4- $N$-alkylgemcitabine analogues with a $\beta$-keto sulfonate moieties were synthesized with the goal of overcoming defluorination that can occur with the presence of hydrogens at the $\beta$ - carbon to the fluorine atom. The presence of these hydrogens have shown to occur in previous PET-imaging results with other 4- $\mathrm{N}$-alkylgemcitabine analogues. ${ }^{38}$ The target analogue was synthesized by coupling the p-toluenesulfonamido group in 4- $\mathrm{N}$ tosylgemcitabine with an alkyl amine possessing a terminal olefin. This terminal olefin was then modified through several oxidation steps to $\beta$-keto with sulfonate groups that have the ability to be fluorinated.

The synthesis of 4- $N$-alkanoylgemcitabines with silicon fluoride acceptor building blocks was achieved by coupling of gemcitabine $\mathbf{1}$ with the various carboxylic acids using peptide coupling conditions (HOBt/EDC). This method was versatile in that it allowed introduction of aliphatic chains with different terminal functional groups such as azido and alkynes that are compatible for click chemistry. The click reaction with dialkylsilylfluoride acceptor building blocks afforded the 4- $\mathrm{N}$-alkanoylsilanegemcitabine analogues in short reaction times and high yield. The synthesis of the 4- $\mathrm{N}$-alkylgemcitabine with silicon fluoride acceptor building block was achieved by displacement of the $p$ toluenesulfonamido group in 4-N-tosylgemcitabine with the corresponding alkyl amine with the terminal azido moiety. Analogously to the alkanoyl analogues, they were coupled 
with dialkylsilyl fluoride acceptor building blocks through click chemistry to afford the 4$\mathrm{N}$-alkylsilanegemcitabine analogue.

Evaluation on mice tumor cell lines (L1210) revealed potent cytotoxic activities for the 4- $N$-alkanoylgemcitabines, with $\mathrm{IC}_{50}$ values in the $\mathrm{nM}$ range, comparable to the parent gemcitabine while the 4-N-alkylgemctiabines displayed almost no cytotoxic activity. Additionally, biological studies were performed to observe the cellular uptake of 4- $\mathrm{N}$-alkyl analogue 86 in HEK293 cells using both HPLC analysis and fluorescence microscopy. These experiments clearly showed that these type of analogues are incorporated into the cell and their lack of hydrolysis into the parent drug inside explain their low cytotoxic activity.

Both 4-N-alkanoyl and 4-N-alkyl modified gemcitabine analogues were then successfully fluorinated following protocols that are used in radiosynthetic settings using KF and Kryptofix-222 at elevated temperatures. In the case of the analogues bearing the silicon-fluoride acceptors, the protocol did not require harsh deprotection steps after fluorination, but the caution of silicon-fluoride hydrolysis was taken into consideration. The 4- $N$-alkylgemcitabine with $\beta$-keto sulfonate analogue was successfully fluorinated via both mesylate and tosylate intermediates followed by a deprotection step. The developed fluorination protocol was then successfully applied for the synthesis of both $\left[{ }^{18} \mathrm{~F}\right]-4-N-[11-$ undecanoyl-(fluoro-di-iso-propylsilyl)- $O$-propargylbenzyltriazol)]gemcitabine and [18F]4- $N$-[7-heptanyl-(fluoro-di-iso-propylsilyl)-O-propargylbenzyltriazol)]gemcitabine radioligands using macroscale and microscale radiolabeling protocols. These radioligands were then evaluated through preliminary stability in formulation studies, in vivo PET imaging and metabolite analysis in blood. 
Lastly, in studying the efficient reduction of lactones to hemiacetals, I developed an efficient protocol for the reduction of sugar $\gamma$ - and $\delta$-lactones with LTBH (1.2 equiv.) in $\mathrm{CH}_{2} \mathrm{Cl}_{2}\left(0^{\circ} \mathrm{C}, 30 \mathrm{~min}\right.$.) to the corresponding hemiacetals. Several ribono- and gulono-1,4lactone as well as glucono-1,5-lactones were reduced to the corresponding pentose or hexose derivatives in high yields. The reduction with LTBH can be carried out in the presence of protecting groups such as trityl, benzyl, silyl (TMS or TBDMS), isopropylidene/benzylidene and to some extent acyl (Bz, or Ac) that are commonly used in the synthetic carbohydrate chemistry. 


\section{REFERENCES}

1 Gesto, D. S.; Cerqueira, N. M. F. S. A.; Fernandes, P. A.; Ramos, M. J. Curr. Med. Chem. 2012, 19, 1076-1087.

2 Toschi, L.; Finocchiaro, G.; Bartolini, S.; Gioia, V.; Cappuzzo, F. Future Oncol. 2005, $1,7-17$.

3 Brown, K.; Dixey, M.; Weymouth-Wilson, A.; Linclau, B. Carbohydr. Res. 2014, 387, 59-73.

4 Hertel, L. W.; Kroin, J. S.; Misner, J. W.; Tustin, J. M. J. Org. Chem. 1988, 53, 2406-2409.

5 Mackey, J. R.; Mani, R. S.; Selner, M.; Mowles, D.; Young, J. D.; Belt, J. A.; Crawford, C. R.; Cass, C. E. Cancer Res. 1998, 58, 4349-4357.

6 Gandhi, V.; Plunkett, W. Cancer Res. 1990, 50, 3675-3680.

7 Huang, P.; Chubb, S.; Hertel, L. W.; Grindey, G. B.; Plunkett, W. Cancer Res. 1991, 51, 6110-6117.

8 Plunkett, W.; Huang, P.; Xu, Y. Z.; Heinemann, V.; Grunewald, R.; Gandhi, V. Semin. Oncol. 1995, 22, 3-10.

9 Mini, E.; Nobili, S.; Caciagli, B.; Landini, I.; Mazzei, T. Ann. Oncol. 2006, 17, v7-v12.

10 Ewald, B.; Sampath, D.; Plunkett, W. Oncogene 2008, 27, 6522-6537.

11 Wang, J.; Lohman, G. J. S.; Stubbe, J. Biochem. 2009, 48, 11612-11621.

12 Lohman, G. J. S.; Stubbe, J. Biochem. 2010, 49, 1404-1417.

13 Baker, C. H.; Banzon, J.; Bollinger, J. M.; Stubbe, J.; Samano, V.; Robins, M. J.; Lippert, B.; Jarvi, E.; Resvick, R. J. Med. Chem. 1991, 34, 1879-1884.

14 Shipley, L. A.; Brown, T. J.; Cornpropst, J. D.; Hamilton, M.; Daniels, W. D.; Culp, H. W. Drug Metab. Dispos. 1992, 20, 849-855.

15 Veltkamp, S. A.; Beijnen, J. H.; Schellens, J. H. M. Oncologist 2008, 13, 261276.

16 Horton, N. D.; Young, J. K.; Perkins, E. J.; Truex, L. L. Cancer Res. 2004, 64, 486-487. 
17 Veltkamp, S. A.; Pluim, D.; van Tellingen, O.; Beijnen, J. H.; Schellens, J. H. M. Drug Metab. Dispos. 2008, 36, 1606-1615.

18 Hodge, L. S.; Taub, M. E.; Tracy, T. S. Drug Metab. Dispos. 2011, 39, 20132016.

19 Moysan, E.; Bastiat, G.; Benoit, J.-P. Mol. Pharm. 2013, 10, 430-444.

20 Song, X.; Lorenzi, P. L.; Landowski, C. P.; Vig, B. S.; Hilfinger, J. M.; Amidon, G. L. Mol. Pharm. 2005, 2, 157-167.

21 Bender, D. M.; Bao, J.; Dantzig, A. H.; Diseroad, W. D.; Law, K. L.; Magnus, N. A.; Peterson, J. A.; Perkins, E. J.; Pu, Y. J.; Reutzel-Edens, S. M.; Remick, D. M.; Starling, J. J.; Stephenson, G. A.; Vaid, R. K.; Zhang, D.; McCarthy, J. R. J. Med. Chem. 2009, 52, 6958-6961.

22 Rejiba, S.; Reddy, L. H.; Bigand, C.; Parmentier, C.; Couvreur, P.; Hajri, A. Nanomedicine 2011, 7, 841-849.

23 Krajewska, E.; Shugar, D. Acta Biochim. Pol. 1975, 22, 185-194.

24 Immordino, M. L.; Brusa, P.; Rocco, F.; Arpicco, S.; Ceruti, M.; Cattel, L. J. Control. Release 2004, 100, 331-346.

25 Chung, W. G.; Sandoval, M. A.; Sloat, B. R.; Lansakara, P. D.; Cui, Z. J. Control. Release 2012, 157, 132-140.

26 Couvreur, P.; Stella, B.; Reddy, L. H.; Hillaireau, H.; Dubernet, C.; Desmaele, D.; Lepetre-Mouelhi, S.; Rocco, F.; Dereuddre-Bosquet, N.; Clayette, P.; Rosilio, V.; Marsaud, V.; Renoir, J. M.; Cattel, L. Nano Lett 2006, 6, 2544-2548.

27 Koolen, S. L.; Witteveen, P. O.; Jansen, R. S.; Langenberg, M. H.; Kronemeijer, R. H.; Nol, A.; Garcia-Ribas, I.; Callies, S.; Benhadji, K. A.; Slapak, C. A.; Beijnen, J. H.; Voest, E. E.; Schellens, J. H. Clin. Cancer Res. 2011, 17, 6071-6082.

28 Pulido, J.; Sobczak, A. J.; Balzarini, J.; Wnuk, S. F. J. Med. Chem. 2014, 57, 191203.

29 May, J. P.; Undzys, E.; Roy, A.; Li, S.-D. Bioconjugate Chem. 2016, 27, 226-237.

30 Dubey, R. D.; Saneja, A.; Gupta, P. K.; Gupta, P. N. Eur. J. Pharm. Sci. 2016, 93, 147-162.

31 Dasari, M.; Acharya, A. P.; Kim, D.; Lee, S.; Lee, S.; Rhea, J.; Molinaro, R.; Murthy, N. Bioconjugate Chem. 2013, 24, 4-8. 
32 Han, H.; Jin, Q.; Wang, Y.; Chen, Y.; Ji, J. Chem. Commun. 2015, 51, 1743517438.

33 Bergman, A. M.; Adema, A. D.; Balzarini, J.; Bruheim, S.; Fichtner, I.;

Noordhuis, P.; Fodstad, Ø.; Myhren, F.; Sandvold, M. L.; Hendriks, H. R.; Peters, G. J. Invest. New Drug. 2011, 29, 456-466.

34 Tsume, Y.; Incecayir, T.; Song, X.; Hilfinger, J. M.; Amidon, G. L. Eur. J. Pharm. Biopharm. 2014, 86, 514-523.

35 Faivre, S. J.; Olszanski, A. J.; Weigang-Köhler, K.; Riess, H.; Cohen, R. B.; Wang, X.; Myrand, S. P.; Wickremsinhe, E. R.; Horn, C. L.; Ouyang, H.; Callies, S.; Benhadji, K. A.; Raymond, E. Invest. New Drug. 2015, 33, 1206-1216.

36 Pratt, S. E.; Durland-Busbice, S.; Shepard, R. L.; Heinz-Taheny, K.; Iversen, P. W.; Dantzig, A. H. Clin. Cancer Res. 2013, 19, 1159-1168.

37 Wickremsinhe, E.; Bao, J.; Smith, R.; Burton, R.; Dow, S.; Perkins, E. Pharmaceutics 2013, 5, 261.

38 Pulido, J. In Design and Synthesis of 4-N-Alkanoyl and 4-N-Alkyl Gemcitabine Analogues Suitable for Positron Emission Tomography; Florida International University, Miami Florida, 2014; Vol. Chemistry

39 Karampelas, T.; Argyros, O.; Sayyad, N.; Spyridaki, K.; Pappas, C.; Morgan, K.; Kolios, G.; Millar, R. P.; Liapakis, G.; Tzakos, A. G.; Fokas, D.; Tamvakopoulos, C. Bioconjugate Chem. 2014, 25, 813-823.

40 Hamsici, S.; Sardan Ekiz, M.; Cinar Ciftci, G.; Tekinay, A. B.; Guler, M. O. Bioconjugate Chem. 2017.

41 Lee, G. Y.; Qian, W. P.; Wang, L.; Wang, Y. A.; Staley, C. A.; Satpathy, M.; Nie, S.; Mao, H.; Yang, L. ACS Nano 2013, 7, 2078-2089.

42 Wang, W.; Li, C.; Zhang, J.; Dong, A.; Kong, D. J. Mater. Chem. B 2014, 2, 1891-1901.

43 Hu, X.; Yan, L.; Xiao, H.; Li, X.; Jing, X. J. Appl. Polym. Sci. 2013, 127, 33653373.

44 Duangjai, A.; Luo, K.; Zhou, Y.; Yang, J.; Kopeček, J. Eur. J. Pharm. Biopharm. 2014, 87, 187-196.

45 Menard-Moyon, C.; Ali-Boucetta, H.; Fabbro, C.; Chaloin, O.; Kostarelos, K.; Bianco, A. Chemistry 2015, 21, 14886-14892. 
46 Kolb, H. C.; Finn, M. G.; Sharpless, K. B. Angew. Chem., Int. Ed. 2001, 40, 20042021.

47 Huisgen, R. Angew. Chem., Int. Ed. 1963, 2, 565-598.

48 Scriven, E. F. V.; Turnbull, K. Chem. Rev. 1988, 88, 297-368.

49 Tron, G. C.; Pirali, T.; Billington, R. A.; Canonico, P. L.; Sorba, G.; Genazzani, A. A. Med. Res. Rev. 2008, 28, 278-308.

50 Rostovtsev, V. V.; Green, L. G.; Fokin, V. V.; Sharpless, K. B. Angew. Chem., Int. Ed. 2002, 41, 2596-2599.

51 Tornøe, C. W.; Christensen, C.; Meldal, M. J. Org. Chem. 2002, 67, 3057-3064.

52 Amblard, F.; Cho, J. H.; Schinazi, R. F. Chem. Rev. 2009, 109, 4207-4220.

53 Hein, C. D.; Liu, X.-M.; Wang, D. Pharm. Res. 2008, 25, 2216-2230.

54 El-Sagheer, A. H.; Brown, T. Chem. Soc. Rev. 2010, 39, 1388-1405.

55 Haque, M. M.; Peng, X. Sci. China Chem. 2014, 57, 215-231.

56 Xi, W.; Scott, T. F.; Kloxin, C. J.; Bowman, C. N. Adv. Funct. Mater. 2014, 24, 2572-2590.

57 Nwe, K.; Brechbiel, M. W. Cancer Biother. Radiopharm. 2009, 24, 289-302.

58 Neef, A. B.; Pernot, L.; Schreier, V. N.; Scapozza, L.; Luedtke, N. W. Angew. Chem., Int. Ed. 2015, 54, 7911-7914.

59 Lee, M. H.; Sessler, J. L.; Kim, J. S. Acc. Chem. Res 2015, 48, 2935-2946.

60 Bhuniya, S.; Lee, M. H.; Jeon, H. M.; Han, J. H.; Lee, J. H.; Park, N.; Maiti, S.; Kang, C.; Kim, J. S. Chem. Commun. 2013, 49, 7141-7143.

61 Maiti, S.; Park, N.; Han, J. H.; Jeon, H. M.; Lee, J. H.; Bhuniya, S.; Kang, C.; Kim, J. S. J. Am. Chem. Soc. 2013, 135, 4567-4572.

62 Yang, Z.; Lee, J. H.; Jeon, H. M.; Han, J. H.; Park, N.; He, Y.; Lee, H.; Hong, K. S.; Kang, C.; Kim, J. S. J. Am. Chem. Soc. 2013, 135, 11657-11662.

63 Liu, L.-H.; Qiu, W.-X.; Li, B.; Zhang, C.; Sun, L.-F.; Wan, S.-S.; Rong, L.; Zhang, X.-Z. Adv. Funct. Mater. 2016, 26, 6257-6269.

64 Gambhir, S. S. Nat. Rev. Cancer 2002, 2, 683-693.

65 Phelps, M. E. Proc. Natl. Acad. Sci. U.S.A. 2000, 97, 9226-9233. 
66 Cai, L.; Lu, S.; Pike, V. W. Eur. J. Org. Chem. 2008, 2008, 2853-2873.

67 Coenen, H. H. In Fluorine-18 Labeling Methods: Features and Possibilities of Basic Reactions; Springer Berlin Heidelberg, Berlin, Heidelberg, 2007. pp 15-50.

68 Jacobson, O.; Kiesewetter, D. O.; Chen, X. Bioconjugate Chem. 2015, 26, 1-18.

69 Park, B. K.; Kitteringham, N. R. Drug Metab. Rev. 1994, 26, 605-643.

70 Orit, J.; Xiaoyuan, C. Curr. Top. Med. Chem. 2010, 10, 1048-1059.

71 Neumann, C. N.; Hooker, J. M.; Ritter, T. Nature 2016, 534, 369-373.

72 Furuya, T.; Kuttruff, C. A.; Ritter, T. Cur. Opin. Drug Discov. Devel. 2008, 11, 803-819.

73 Lemaire, C.; Cantineau, R.; Guillaume, M.; Plenevaux, A.; Christiaens, L. J. Nucl. Med. 1991, 32, 2266-2272.

74 Gründer, G.; Siessmeier, T.; Lange-Asschenfeldt, C.; Vernaleken, I.; Buchholz, H.-G.; Stoeter, P.; Drzezga, A.; Lüddens, H.; Rösch, F.; Bartenstein, P. Eur. J. Nucl. Med. 2001, 28, 1463-1470.

75 Farwell, M. D.; Pryma, D. A.; Mankoff, D. A. Cancer 2014, 120, 3433-3445.

76 Alauddin, M. M. Am. J. Nucl. Med. Mol. Img. 2012, 2, 55-76.

77 Britton, T.; Robinson, N. J. Nucl. Med. Technol. 2016, 44, 59-64.

78 Pretze, M.; Wangler, C.; Wangler, B. BioMed Res. Int. 2014, 2014, 12.

79 Zanzonico, P. In Prostate Cancer: 16 $\beta$-[18F] Fluoro-5 $\alpha$-Dihydrotesterone (FDHT) Whole-Body Positron Emission Tomography; Springer Netherlands, Dordrecht, 2008. pp 521-530.

80 Wagner, M.; Seitz, U.; Buck, A.; Neumaier, B.; Schultheiß, S.; Bangerter, M.; Bommer, M.; Leithäuser, F.; Wawra, E.; Munzert, G.; Reske, S. N. Cancer Res. 2003, 63, 2681-2687.

81 Radu, C. G.; Shu, C. J.; Nair-Gill, E.; Shelly, S. M.; Barrio, J. R.; Satyamurthy, N.; Phelps, M. E.; Witte, O. N. Nat. Med. 2008, 14, 783-788.

82 Laing, R. E.; Walter, M. A.; Campbell, D. O.; Herschman, H. R.; Satyamurthy, N.; Phelps, M. E.; Czernin, J.; Witte, O. N.; Radu, C. G. Proc. Natl. Acad. Sci. U.S.A. 2009, 106, 2847-2852. 
83 Schwarzenberg, J.; Radu, C. G.; Benz, M.; Fueger, B.; Tran, A. Q.; Phelps, M. E.; Witte, O. N.; Satyamurthy, N.; Czernin, J.; Schiepers, C. Eur. J. Nucl. Med. Mol. Imaging 2011, 38, 711-721.

84 Hoover, A. J.; Lazari, M.; Ren, H.; Narayanam, M. K.; Murphy, J. M.; van Dam, R. M.; Hooker, J. M.; Ritter, T. Organometallics 2016, 35, 1008-1014.

85 Gens, T. A.; Wethongton, J. A.; Brosi, A. R. J. Phys. Chem. 1958, 62, 1593-1593.

86 Winfield, J. M. J. Fluorine Chem. 1980, 16, 1-17.

87 Rosenthal, M. S.; Bosch, A. L.; Nickles, R. J.; Gatley, S. J. Int. J. Appl. Radiat. Is. 1985, 36, 318-319.

88 Choudhry, U.; Martin, K. E.; Biagini, S.; Blower, P. J. Nucl. Med. Commun. 2006, 27, 293.

89 Schirrmacher, R.; Bradtmöller, G.; Schirrmacher, E.; Thews, O.; Tillmanns, J.; Siessmeier, T.; Buchholz, H. G.; Bartenstein, P.; Wängler, B.; Niemeyer, C. M.; Jurkschat, K. Angew. Chem., Int. Ed. 2006, 45, 6047-6050.

90 Mu, L.; Hohne, A.; Schubiger, P. A.; Ametamey, S. M.; Graham, K.; Cyr, J. E.; Dinkelborg, L.; Stellfeld, T.; Srinivasan, A.; Voigtmann, U.; Klar, U. Angew. Chem. Int. Ed. Engl. 2008, 47, 4922-4925.

91 Höhne, A.; Yu, L.; Mu, L.; Reiher, M.; Voigtmann, U.; Klar, U.; Graham, K.; Schubiger, P. A.; Ametamey, S. M. Chem-Eur J. 2009, 15, 3736-3743.

92 Schirrmacher, E.; Wängler, B.; Cypryk, M.; Bradtmöller, G.; Schäfer, M.; Eisenhut, M.; Jurkschat, K.; Schirrmacher, R. Bioconjugate Chem. 2007, 18, 2085-2089.

93 Wängler, C.; Niedermoser, S.; Chin, J.; Orchowski, K.; Schirrmacher, E.; Jurkschat, K.; Iovkova-Berends, L.; Kostikov, A. P.; Schirrmacher, R.; Wängler, B. Nat. Protocols 2012, 7, 1946-1955.

94 Wängler, C.; Kostikov, A.; Zhu, J.; Chin, J.; Wängler, B.; Schirrmacher, R. Appl. Sci. 2012, 2, 277.

95 Tietze, L. F.; Schmuck, K. Synlett 2011, 2011, 1697-1700.

96 Iovkova, L.; Könning, D.; Wängler, B.; Schirrmacher, R.; Schoof, S.; Arndt, H.D.; Jurkschat, K. Eur. J. Inorg. Chem. 2011, 2011, 2238-2246.

97 Wuest, F.; Berndt, M.; Bergmann, R.; van den Hoff, J.; Pietzsch, J. Bioconjugate Chem. 2008, 19, 1202-1210. 
98 Wängler, B.; Kostikov, A. P.; Niedermoser, S.; Chin, J.; Orchowski, K.;

Schirrmacher, E.; Iovkova-Berends, L.; Jurkschat, K.; Wängler, C.; Schirrmacher, R. Nat. Protocols 2012, 7, 1964-1969.

99 Schulz, J.; Vimont, D.; Bordenave, T.; James, D.; Escudier, J.-M.; Allard, M.; Szlosek-Pinaud, M.; Fouquet, E. Chem-Eur J. 2011, 17, 3096-3100.

100 James, D.; Escudier, J.-M.; Amigues, E.; Schulz, J.; Vitry, C.; Bordenave, T.; Szlosek-Pinaud, M.; Fouquet, E. Tetrahedron Lett. 2010, 51, 1230-1232.

101 Chaveriat, L.; Stasik, I.; Demailly, G.; Beaupère, D. Tetrahedron Asymmetr. 2005, 16, 623-627.

102 Lalot, J.; Stasik, I.; Demailly, G.; Beaupère, D. Carbohydr. Res. 2003, 338, 22412245.

103 Lalot, J.; Manier, G.; Stasik, I.; Demailly, G.; Beaupère, D. Carbohydr. Res. 2001, 335, 55-61.

104 Takahashi, H.; Hitomi, Y.; Iwai, Y.; Ikegami, S. J. Am. Chem. Soc. 2000, 122, 2995-3000.

105 Wolf, J.; Jarrige, J. M.; Florent, J. C.; Grierson, D. S.; Monneret, C. Synthesis 1992, 773-778.

106 Beach, J. W.; Kim, H. O.; Jeong, L. S.; Nampalli, S.; Islam, Q.; Ahn, S. K.; Babu, J. R.; Chu, C. K. J. Org. Chem. 1992, 57, 3887-3894.

107 Chou, T. S.; Heath, P. C.; Patterson, L. E.; Poteet, L. M.; Lakin, R. E.; Hunt, A. H. Synthesis 1992, 1992, 565-570.

108 Choi, W. B.; Wilson, L. J.; Yeola, S.; Liotta, D. C.; Schinazi, R. F. J. Am. Chem. Soc. 1991, 113, 9377-9379.

109 Seyden-Penne, J.; Editor Reductions by the Alumino- and Borohydrides in Organic Synthesis, Second Edition; Wiley, 1997.

110 Malladi, V. L. A.; Sobczak, A. J.; Meyer, T. M.; Pei, D.; Wnuk, S. F. Bioorg. Med. Chem. 2011, 19, 5507-5519.

111 Malladi, V. L. A.; Sobczak, A. J.; Maricic, N.; Murugapiran, S. K.; Schneper, L.; Makemson, J.; Mathee, K.; Wnuk, S. F. Bioorg. Med. Chem. 2011, 19, 5500-5506.

112 Chbib, C.; Sobczak, A. J.; Mudgal, M.; Gonzalez, C.; Lumpuy, D.; Nagaj, J.; Stokowa-Soltys, K.; Wnuk, S. F. J. Sulfur. Chem. 2016, 307-327. 
113 Fleming, I. Comprehensive Organic Synthesis: Selectivity, Strategy and Efficiency in Modern Organic Chemistry, Volume 8: Reduction; Pergamon, 1992.

114 Cragg, G. M. L. Organoboranes in Organic Synthesis; Dekker, 1973.

115 Abdek-Akher, M.; Hamilton, J. K.; Smith, F. J. Am. Chem. Soc. 1951, 73, 46914692.

116 Andriescu, A. Cellul. Chem. Technol. 1998, 32, 163.

117 Santaniello, E.; Ferraboschi, P.; Sozzani, P. J. Org. Chem. 1981, 46, 4584-4585.

118 Brown, H. C.; Rao, B. C. S. J. Am. Chem. Soc. 1955, 77, 3164-3164.

119 Ishii, H.; Dzyuba, S. V.; Nakanishi, K. Org. Biomol. Chem. 2005, 3, 3471-3472.

120 Xavier, N. M.; Rauter, A. P.; Queneau, Y. Top. Curr. Chem. 2010, 295, 19-62.

121 Verdaguer, X.; Hansen, M. C.; Berk, S. C.; Buchwald, S. L. J. Org. Chem. 1997, $62,8522-8528$.

122 Verdaguer, X.; Berk, S. C.; Buchwald, S. L. J. Am. Chem. Soc. 1995, 117, 1264112642.

123 de Talancé, V. L.; Thiery, E.; Eppe, G.; Bkassiny, S. E.; Mortier, J.; Vincent, S. P. J. Carbohydr. Chem. 2011, 30, 605-617.

124 Hamed, R. B.; Henry, L.; Gomez-Castellanos, J. R.; Mecinović, J.; Ducho, C.; Sorensen, J. L.; Claridge, T. D. W.; Schofield, C. J. J. Am. Chem. Soc. 2012, 134, 471479.

125 Zanardi, F.; Battistini, L.; Nespi, M.; Rassu, G.; Spanu, P.; Cornia, M.; Casiraghi, G. Tetrahedron Asymmetr. 1996, 7, 1167-1180.

126 Bernard-Gauthier, V.; Wangler, C.; Schirrmacher, E.; Kostikov, A.; Jurkschat, K.; Wangler, B.; Schirrmacher, R. BioMed Res. Int. 2014, 2014, 20.

127 Sigmond, J.; Honeywell, R. J.; Postma, T. J.; Dirven, C. M. F.; de Lange, S. M.; van der Born, K.; Laan, A. C.; Baayen, J. C. A.; Van Groeningen, C. J.; Bergman, A. M.; Giaccone, G.; Peters, G. J. Ann. Oncol. 2009, 20, 182-187.

128 Cividini, F.; Filoni, D. N.; Pesi, R.; Allegrini, S.; Camici, M.; Tozzi, M. G. Biochim. Biophys. Acta 2015, 1850, 1354-1361.

129 Kim, W.; Le, T. M.; Wei, L.; Poddar, S.; Bazzy, J.; Wang, X.; Uong, N. T.; Abt, E. R.; Capri, J. R.; Austin, W. R.; Van Valkenburgh, J. S.; Steele, D.; Gipson, R. M.; Slavik, R.; Cabebe, A. E.; Taechariyakul, T.; Yaghoubi, S. S.; Lee, J. T.; Sadeghi, S.; 
Lavie, A.; Faull, K. F.; Witte, O. N.; Donahue, T. R.; Phelps, M. E.; Herschman, H. R.; Herrmann, K.; Czernin, J.; Radu, C. G. Proc. Natl. Acad. Sci. U.S.A. 2016, 113, 40274032.

130 Ho, D. H. W. Cancer Res. 1973, 33, 2816-2820.

131 Neef, A. B.; Luedtke, N. W. ChemBioChem 2014, 15, 789-793.

132 Chang, P. V.; Bertozzi, C. R. Chem. Commun. 2012, 48, 8864-8879.

133 Thirumurugan, P.; Matosiuk, D.; Jozwiak, K. Chem. Rev. 2013, 113, 4905-4979.

134 Ishizuka, T.; Liu, H. S.; Ito, K.; Xu, Y. Sci. Rep-UK 2016, 6, 33217.

135 Gierlich, J.; Burley, G. A.; Gramlich, P. M. E.; Hammond, D. M.; Carell, T. Org. Lett. 2006, 8, 3639-3642.

136 Ngo, J. T.; Schuman, E. M.; Tirrell, D. A. Proc. Natl. Acad. Sci. U.S.A. 2013, 110, 4992-4997.

137 Winz, M.-L.; Samanta, A.; Benzinger, D.; Jäschke, A. Nucleic Acids Res. 2012, 40, e78-e78.

138 Keng, P. Y.; Chen, S.; Ding, H.; Sadeghi, S.; Shah, G. J.; Dooraghi, A.; Phelps, M. E.; Satyamurthy, N.; Chatziioannou, A. F.; Kim, C.-J. C.; van Dam, R. M. Proc. Natl. Acad. Sci. U.S.A. 2012, 109, 690-695.

139 Keng, P. Y.; Dam, R. M. v. Mol. Imaging 2015, 14, 7290.2015.00030.

140 Kamijo, S.; Dudley, G. B. J. Am. Chem. Soc. 2006, 128, 6499-6507.

141 Denolf, B.; Leemans, E.; De Kimpe, N. J. Org. Chem. 2007, 72, 3211-3217.

142 Evans, D. A.; Dow, R. L.; Shih, T. L.; Takacs, J. M.; Zahler, R. J. Am. Chem. Soc. 1990, 112, 5290-5313.

143 Blough, B. E.; Carroll, F. I. Tetrahedron Lett. 1993, 34, 7239-7242.

144 Brown, H. C.; Kim, S. C.; Krishnamurthy, S. J. Org. Chem. 1980, 45, 1-12.

145 Hanessian, S.; Girard, C.; Chiara, J. L. Tetrahedron Lett. 1992, 33, 573-576.

146 Landsmann, S.; Luka, M.; Polarz, S. Nat. Commun. 2012, 3, 1299.

147 Cao, Y.; Galoppini, E.; Reyes, P. I.; Lu, Y. Langmuir 2013, 29, 7768-7775.

148 Roe, S.; Gunaratnam, M.; Spiteri, C.; Sharma, P.; Alharthy, R. D.; Neidle, S.; Moses, J. E. Org. Biomol. Chem. 2015, 13, 8500-8504. 
149 Ohkubo, A.; Noma, Y.; Aoki, K.; Tsunoda, H.; Seio, K.; Sekine, M. J. Org. Chem. 2009, 74, 2817-2823.

150 Gonzalez, C.; Kavoosi, S.; Sanchez, A.; Wnuk, S. F. Carbohydr. Res. 2016, 432, $17-22$.

151 Elend, M. D.; Fray, J.; Pryde, D. Arkivoc 2006, 114-127.

152 Elhalem, E.; Comin, M. J.; Leitofuter, J.; García-Liñares, G.; Rodriguez, J. B.

Tetrahedron Asymmetr. 2005, 16, 425-431.

153 Dasgupta, S.; Nitz, M. J. Org. Chem. 2011, 76, 1918-1921. 
VITA

\section{CESAR GONZALEZ}

Born, Santiago, Chile

2006-2011

B.A., Chemistry

Florida International University

Miami, Florida

2013-2017

Doctoral candidate

Florida International University

Miami, Florida

2017

SoFLACS Graduate Travel Award

\section{PUBLICATIONS AND PRESENTATIONS}

Chbib, C., Sobczak, A. J., Mudgal, M., Gonzalez, C., Lumpuy, D., Nagaj, J., StokowaSoltys, K., and Wnuk, S. F. (2016) S-Ribosylhomocysteine analogues modified at the ribosyl C-4 position, Journal of Sulfur Chemistry, 307-327.

Gonzalez, C., Kavoosi, S., Sanchez, A., and Wnuk, S. F. (2016) Reduction of sugar lactones to lactols with lithium triethylborohydride, Poster presented at 251st ACS National Meeting \& Exposition, San Diego, California.

Gonzalez, C., Kavoosi, S., Sanchez, A., and Wnuk, S. F. (2016) Reduction of sugar lactones to hemiacetals with lithium triethylborohydride, Carbohydrate Research. 432, 1722.

Gonzalez, C., Sanchez, A., and Wnuk, S. F. (2017) Clickable 4-N-alkanoyl and 4-Nalkylgemcitabine analogues with silicon-fluoride acceptors, Poster presented at 253rd ACS National Meeting \& Exposition, San Francisco, California.

de Cabrera, M., Gonzalez, C., Sulimoff, N., and Wnuk, S. F. (2017) Synthesis of 4-N-Alkyl Gemcitabine Analog Bearing $\beta$-Keto Tosylate Moiety Suitable for 18F-Labeling, Poster presented at 253rd ACS National Meeting \& Exposition, San Francisco, California.

Collins J., Lisova, K., Gonzalez, C., Wnuk S.F., and van Dam, M (2017) Microscale and conventional radiosynthesis of ${ }^{18}$ F-labeled gemcitabine analog via silicon-fluorideacceptor chemistry, oral presentation at 22nd International Symposium on Radiopharmaceutical Sciences, Dresden, Germany. 
Gonzalez, C., De Cabrera, M., and Wnuk, S.F. (2017) Fluorination of 4-N-Alkyl Gemcitabine Analogues with $\beta$-Keto Sulfonate Moieties. Nucleosides, Nucleotides and Nucleic acids (in preparation).

Gonzalez, C., Sanchez, A., Collins, J., Lisova, K., van Dam, M., Barbieri, M. A., Ramachandran, C., and Wnuk, S.F. (2017) The 4-N-Alkyl Gemcitabine Analogues with Silicon-Fluoride-Acceptor: Application to 18-Fluorine radiolabeling. Journal of Medicinal Chemistry (in preparation). 